\title{
CURRENT ISSUES OF HEALTH CARE AND PHYSICAL REHABILITATION
}

Collective monograph






\section{Reviewers:}

dr Marek Zielinski, Dean of the Faculty of Health Sciences of Cuiavian University in Wloclawek (Republic of Poland);

$d r$ n. o zdr. Wioletta Wojciechowska, Faculty of Health Sciences of Cuiavian University in Wloclawek (Republic of Poland).

Current issues of health care and physical rehabilitation : collective monograph / G. O. Slabkiy, V. Yo. Bilak-Lukianchuk, V. V. Brych, D. V. Danko, A.-M. M. Pishkovtsi, A. O. Keretsman, O. V. Zhdanova, I. S. Myronyuk, A. P. Spivak, K. S. Barannik. - Lviv-Toruń : Liha-Pres, 2019. - $184 \mathrm{p}$.

ISBN 978-966-397-155-1

Liha-Pres is an international publishing house which belongs to the category "C" according to the classification of Research School for Socio-Economic and Natural Sciences of the Environment (SENSE) [isn: 3943, 1705, 1704, 1703, 1702, 1701; prefixMetCode: 978966397]. Official website www.sense.nl. 


\section{CONTENTS}

DESCRIPTION OF PERSONNEL PROVISION

OF HEALTH CARE SYSTEM OF UKRAINE..........................................1

Slabkiy G. $O$.

TRAINING OF PUBLIC HEALTH PROFESSIONALS

IN UKRAINE: EXPERIENCE AND PROBLEMS 26

Bilak-Lukianchuk V. Yo.

CHARACTERISTICS OF TRAUMATISM

OF THE POPULATION OF TRANSCARPATHIAN REGION .44

Brych V. V.

CHARACTERISTICS OF THE NETWORK OF HEALTH

CARE INSTITUTIONS AND PERSONNEL OF THE

TRANSCARPATHIAN REGIONAL HEALTH CARE SYSTEM 62

Danko D. V.

ANALYSIS OF INDICATORS OF DENTAL HEALTH'S ADULT POPULATION OF THE TRANSCARPATHIA REGION AND PROVIDING THEM SPECIALIZED MEDICAL CARE IN THE PUBLIC HEALTH SECTOR 80

Pishkovtsi A.-M. M.

RECEIVING AND MAINTAINING HEALTH WORKFORSE RESOURSES IN WHO STRATEGIC DOCUMENTS 100

Keretsman A. O.

DESCRIPTION OF UKRAINIAN STUDENTS' AWARENESS

OF PERSONAL HEALTH PROTECTION AND THEIR LIFESTYLE

STUDY RESULTS

Zhdanova O. V.

STATE OF READINESS FOR THE HEALTH SYSTEM

OF UKRAINE FOR IMPLEMENTATION OF A NEW MODEL

OF REHABILITATION AID

Myronyuk I. S. 
ORGANIZATIONAL MODEL OF A MULTIDISCIPLINARY

APPROACH AT THE STAGE OF THE ESTABLISHMENT

OF A NEW REHABILITATION SYSTEM IN UKRAINE...

Spivak A. P.

EVOLUTIONAL CHANGES IN MODERN THINKING

IN MEDICAL STUDENTS AND THEIR INTEGRATION

IN HIGHER MEDICAL EDUCATION 166

Barannik K. S. 


\section{DESCRIPTION OF PERSONNEL PROVISION OF HEALTH CARE SYSTEM OF UKRAINE}

\section{Slabkiy G. 0.}

\section{INTRODUCTION}

WHO pays much attention to the issues of medical personnel provision of health care system ${ }^{1}$. WHO notes that the effectiveness of health care systems operation depends on their being provided with highly qualified medical personnel ${ }^{2}$. At the same time, the WHO notes the importance of providing with not only doctors, but also with mid-level medical personnel for the effective operation of the system ${ }^{3},{ }_{4}$. It should be noted that during recent years, in the course of medical care, the role of mid-level medical personnel in health care process has significantly increased ${ }^{56}$, . Mid-level medical workers perform not only routine medical services, but also a significant number of medical procedures, which previously were performed exclusively by doctors.

WHO notes that at this stage, almost all countries of the world are experiencing problems with human resources in health care ${ }^{7}$ For their decision WHO approved the Global Strategy for the development of human resources of health care ${ }^{8}$.

\footnotetext{
${ }^{1}$ Junious DL et al. (2004). A study of school nurse job satisfaction. Journal of School Nursing, 20:88-93.

${ }^{2}$ Совместная работа на благо здоровья. Доклад о состоянии здравоохранения в мире, 2006 г.// https://www.who.int/topics/health_workforce/ru/

${ }^{3}$ Razvitie medicinskih kadrov [Medical personnel development]. WHO: website. Retrieved from: http://whodc.mednet.ru/ru/component/attachments/download/20.html (accessed 13 November 2019).

${ }^{4}$ Gupta $\mathrm{N}$ et al. (2003). Uses of population census data for monitoring geographical imbalance in the health workforce: snapshots from three developing countries. International Journal for Equity in Health, 2:11.

${ }^{5}$ Maier, C. B., \& Aiken, L. H. (2016). Task shifting from physicians to nurses in primary care in 39 countries: a cross-country comparative study. European Journal of Public Health, 26(6), 927-934.

${ }^{6}$ Boerma, W.G.W., Kringos, D.S., Wiegers, T.A., Baltag, V., \& Khimion, L. (2010). Evaluation of structure and provision of primary care in Ukraine: a survey-based project in the regions of Kiev and Vinnitsa.

${ }^{7}$ Галієнко Л. І. Сучасні кадрові проблеми охорони здоровя в країнах Європейського регіону ВООЗ. Східноєвропейський журнал громадського здоров'я. 2011. №1 (13). С. 279-281.

${ }^{8}$ Kadry zdravoohraneniya 2030. Globalnaya strategiya dlya razvitiya kadrovyh resursov zdravoohraneniya [Health personnel 2030. Global strategy for health workforce development. WHO: website. Retrieved from: https://www.who.int/hrh/resources/russian_global strategyHRH.pdf (accessed 12 November 2019).
} 
The strengthening of the problem of the provision of health systems by medical personnel in some countries is due to their migration ${ }^{9}$. At the same time, statistically reliable data on the volume of migration of medical workers are absent ${ }^{10}$. Taking into account personnel provision problems which are increasing with regard to labor migration of medical workers WHO adopted The Commonwealth Code of international recruitment of health care personnel, which establishes the guidelines for the international recruitment of medical workers ${ }^{11}$. This document is important also for Ukraine. WHO also pays considerable attention to the issues of attracting and retaining health workers, especially in rural areas ${ }^{12}$.

In order to study the problems associated with personnel resources, WHO developed and recommended for the countries the methodology which is applied at present in Ukraine ${ }^{13}$.

Many scientists in Ukraine are engaged in the problems of human resources in health care: Lekhan V.M. ${ }^{14}$, Slabkiy G.O. ${ }^{15}$, Vezhnovets T.A. ${ }^{16}$, Voronenko Yu.V. ${ }^{17}$, Vasyuk N.O. ${ }^{18}$ et al.

${ }^{9}$ Forcier MB et al. (2004). Impact, regulation and health policy implications of physician migration in OECD countries. Human Resources for Health, 2:12.

${ }^{10}$ Diallo K. Data on the migration of health-care workers: sources, uses, and challenges. Bulletin of the World Health Organization, 2004, 82:559-636.

${ }^{11}$ Commonwealth Code of Practice for the International Recruitment of Health Workers. London, Commonwealth Secretariat, 2003(http://www.thecommonwealth.org/ shared_asp_files/ uploadedfiles/\{7BDD970B-53AE-441D-81DB-

1B64C37E992A\}_CommonwealthCodeofPractice.pdf,accessed 15 April 2008.

12 Rasshirenie dostupa $\mathrm{k}$ rabotnikam zdravoohraneniya $\mathrm{v}$ otdalennyh $\mathrm{i}$ selskih rajonah. Rekomendacii po globalnoj politike. [Increased access to health workers in remote and rural areas. Global policy recommendations]. WHO: website. Retrieved from: http://www.who.int/entity/hrh/ retention/retention_recommendations_ru.pdf (accessed 11 November 2019).

13 Ocenka finansirovaniya, obrazovaniya, upravleniya i politicheskogo konteksta dlya strategicheskogo planirovaniya kadrovyh resursov zdravoohraneniya [Assessment of financing, education, governance and policy context for strategic health workforce planning]. WHO: website. Retrieved from: (http://apps.who.int/gb/ebwha/pdf_files/WHA59-REC1/r/Part2-Resru.pdf) (accessed 14 November 2019).

14 Лехан В. М., Крячкова Л. В. Наукове обгрунтування сучасних підходів до підготовки керівних медичних кадрів. Кадрова політика у сфері охорони здоров'я в умовах загроз національній безпеиі України : матеріали щорічної наук.-практ. конф. за міжнар. участю (Київ, 23 берез. 2017 р.). Київ. С. 86-89.

15 Слабкий Г.О. Кадрова політика. URL : http://www.uiph.kiev.ua/index.asp?p= information\&s $=2$

${ }^{16}$ Вежновець Т. А. До питання визначення критеріївпрофесійного психологічного добору керівників закладів охорони здоров'я. Украйнський журнал з проблем медииини npaui. 2014. №1. С. 28-36.

${ }_{17}^{17}$ Вороненко В., Фещенко І. Кадри забезпечують успіх. Ваме здоров'я. 2011. № 49. URL : http:// www.vz.kiev.ua/?p=3813.

18 Васюк Н. О. Удосконалення кадрового забезпечення державного управління охороною здоров 'я в Україні. Збірник наукових праць Національної академії державного управління при Президентові України. 2015. Вип. 2. С. 34-51 
In their works they indicate the irrational use of medical personnel, low level of their motivation to effective work. The researchers also note the insufficient level of medical skills, mismatch of the ratio of doctors and nurses with the needs, uneven provision of rural residents and residents of cities with medical staff. This situation requires the improvement of personnel policy in health care system of Ukraine.

This is especially important in the conditions of the reform of the healthcare system in the country ${ }^{19}, 20$.

This is especially important in the conditions of the reform of the healthcare system in the country.

In this work we studied and analyzed the issues of provision with doctors and mid-level health workers by the regions of Ukraine for the period of 2014-2018 years.

Statistics of the Ministry of Health of Ukraine and the material of situational analysis "Human resources of the healthcare system in Ukraine" were used in the course of performing this study ${ }^{21}, 22$.

\section{Provision with medicinal personnel in terms of administrative territories}

At first statistics on the provision of the population with doctors in terms of regions of Ukraine was studied and analyzed. The received data are shown in Table 1.

\footnotetext{
${ }^{19}$ Національна стратегія реформування системи охорони здоров'я в Україні на період 2015-2020 років. URL: https://moz.gov.ua/uploads/0/691-strategiya.pdf.

20 Розпорядження Кабінету Міністрів України від 30.11.2016 № 1013-p «Про схвалення Концепції реформи фінансування системи охорони здоров'я». URL: https://zakon.rada.gov.ua/laws/show/1013-2016-p.

21 Державний заклад «Центр медичної статистики Міністерства охорони здоров’я України». URL: http://medstat.gov.ua.

${ }^{22}$ Кадрові ресурси системи охорони здоров'я в Україні. Ситуаційний аналіз / Д. Богдан, А. Бойко, А. Василькова та ін. Проект USAID «Підтримка реформи охорони здоров'я». Київ, 2019. - 133 с.
} 
Table 1

Medical positions in the regions of Ukraine, 2014

\begin{tabular}{|c|c|c|c|c|c|c|c|c|c|c|c|}
\hline Region & 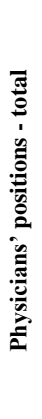 & 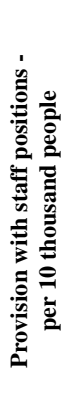 & 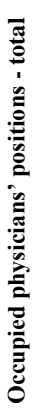 & 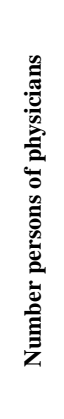 & 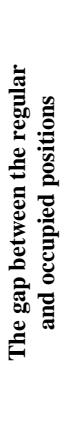 & 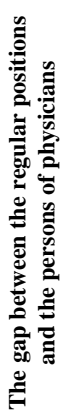 & 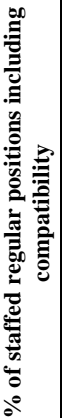 & 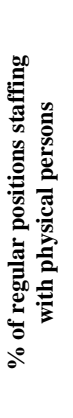 & 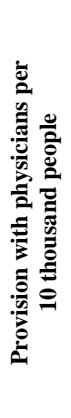 & 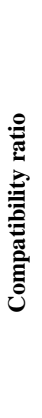 & 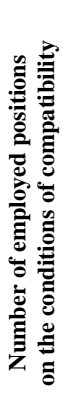 \\
\hline 1 & 2 & 3 & 4 & 5 & 6 & 7 & 8 & 9 & 10 & 11 & 12 \\
\hline Ukraine & 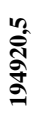 & $\begin{array}{l}\text { की } \\
\text { की }\end{array}$ & 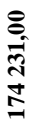 & $\begin{array}{l}\text { है } \\
\text { ì } \\
\text { îे }\end{array}$ & $\begin{array}{l}\text { na. } \\
\hat{0} \\
\text { ते }\end{array}$ & $\begin{array}{l}\frac{n}{n} \\
\frac{n}{4}\end{array}$ & ले & $\begin{array}{l}\text { s. } \\
\text { î }\end{array}$ & $\underset{\text { s }}{F}$ & $\stackrel{g}{=}$ & $\begin{array}{l}\text { s. } \\
\text { î̀ } \\
\text { İ } \\
\text { I }\end{array}$ \\
\hline Vinnitsa & ๙2 & $\overrightarrow{8}$ & ñ & - & $\begin{array}{l}\text { ָ̃ } \\
\stackrel{2}{2}\end{array}$ & $\begin{array}{l}\frac{2}{k} \\
\text { ḋ } \\
\infty\end{array}$ & $\begin{array}{l}F \\
\&\end{array}$ & $\begin{array}{l}2 \\
\\
\text { ฌे }\end{array}$ & $\stackrel{\vec{f}}{\vec{f}}$ & 후 & nू \\
\hline Volyn & 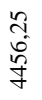 & $\begin{array}{l}+ \\
\infty \\
\sim \\
f\end{array}$ & $\begin{array}{l}n \\
\stackrel{n}{\Xi} \\
\exists\end{array}$ & 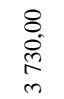 & 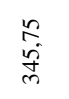 & $\begin{array}{l}\text { â } \\
\text { है } \\
\text { n. }\end{array}$ & $\begin{array}{l}\text { त̃ } \\
\text { }\end{array}$ & $\hat{\infty}$ & $\begin{array}{l}\infty \\
\infty \\
\ddot{m}\end{array}$ & $=$ & $\begin{array}{l}n \\
\tilde{o} \\
\infty \\
m\end{array}$ \\
\hline Dnipropetrovsk & $\begin{array}{l}8 \\
0 \\
0 \\
\text { ర } \\
0\end{array}$ & $\begin{array}{l}\stackrel{2}{\hat{n}} \\
\text { in }\end{array}$ & 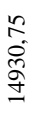 & $\begin{array}{l}8 \\
\dot{\infty} \\
\infty \\
\infty \\
\simeq \\
\simeq\end{array}$ & 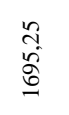 & $\begin{array}{l}8 \\
\text { లi } \\
\infty \\
\infty \\
\text { m }\end{array}$ & $\begin{array}{l}\infty \\
\infty \\
\infty\end{array}$ & $\frac{m}{\approx}$ & ले & $\stackrel{0}{=}$ & $\begin{array}{l}\stackrel{2}{a} \\
\frac{a}{n}\end{array}$ \\
\hline Donetsk & $\begin{array}{l}8 \\
8 \\
\delta \\
\infty \\
\infty\end{array}$ & $\begin{array}{l}\text { o. } \\
\infty \\
\infty\end{array}$ & 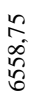 & $\begin{array}{l}8 \\
8 \\
i \\
0 \\
0 \\
i n\end{array}$ & $\begin{array}{l}\stackrel{2}{n} \\
\frac{f}{ \pm}\end{array}$ & $\begin{array}{l}\frac{8}{i} \\
\text { ते } \\
\text { त }\end{array}$ & $\frac{\sigma}{\infty}$ & $\begin{array}{l}\sqrt{n} \\
\text { ภิ }\end{array}$ & $\begin{array}{l}\infty \\
=\end{array}$ & సे & $\begin{array}{l}\frac{n}{a} \\
\text { ma } \\
\dot{g}\end{array}$ \\
\hline Zhytomyr & $\frac{n}{n}$ & $\begin{array}{l}\stackrel{g}{+} \\
\mathfrak{f}\end{array}$ & $\begin{array}{l}8 \\
\infty \\
\infty \\
0 \\
i n\end{array}$ & 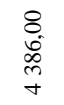 & $\begin{array}{l}n \\
n \\
\infty \\
n \\
n\end{array}$ & $\begin{array}{l}\text { n. } \\
\text { m. } \\
m\end{array}$ & $\begin{array}{l}\dot{8} \\
\dot{8}\end{array}$ & 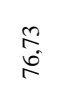 & से & $\stackrel{\infty}{=}$ & $\begin{array}{l}8 \\
\substack{\text { in } \\
\infty \\
\infty}\end{array}$ \\
\hline
\end{tabular}


Continuation Table 1

\begin{tabular}{|c|c|c|c|c|c|c|c|c|c|c|c|}
\hline 1 & 2 & 3 & 4 & 5 & 6 & 7 & 8 & 9 & 10 & 11 & 12 \\
\hline Transcarpathian & $\begin{array}{l}8 \\
o \\
o \\
i n \\
+\end{array}$ & $\begin{array}{l}\text { J } \\
\text { s. }\end{array}$ & 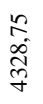 & $\begin{array}{l}8 \\
8 \\
b \\
b \\
+\end{array}$ & $\begin{array}{l}\text { ते } \\
\text { हैं } \\
\text { ते }\end{array}$ & $\begin{array}{l}8 \\
\substack{0 \\
1 \\
1}\end{array}$ & $\begin{array}{l}n \\
\text { ñ } \\
\text { q }\end{array}$ & $\begin{array}{l}8 \\
8 \\
\end{array}$ & $\begin{array}{l}\text { d. } \\
\text { in }\end{array}$ & $\tilde{\sigma}_{0}$ &  \\
\hline Zaporizhia & $\begin{array}{l}n \\
\text { nn } \\
\infty \\
a\end{array}$ & $\begin{array}{l}\bar{b} \\
\text { in } \\
\text { in }\end{array}$ & 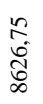 & 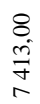 & $\begin{array}{l}\stackrel{n}{2} \\
\stackrel{\infty}{\infty} \\
\stackrel{\infty}{=}\end{array}$ & \begin{tabular}{l} 
ñ \\
aे \\
\multirow{d}{*}{}
\end{tabular} & $\begin{array}{l}\infty \\
\dot{\infty} \\
\dot{\infty} \\
\dot{\infty}\end{array}$ & $\begin{array}{l}\sqrt{n} \\
\text { s. } \\
\end{array}$ & $\begin{array}{l}\underset{\text { d }}{f} \\
\text { for }\end{array}$ & $\stackrel{0}{=}$ & $\begin{array}{l}\frac{n}{2} \\
\stackrel{m}{\Omega}\end{array}$ \\
\hline $\begin{array}{l}\text { Ivano- } \\
\text { Frankivsk }\end{array}$ & à & $\begin{array}{l}\infty \\
\text { î } \\
\text { in }\end{array}$ & 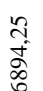 & $\begin{array}{l}8 \\
8 \\
0 \\
0\end{array}$ & 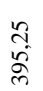 & $\begin{array}{l}n \\
\infty \\
\infty \\
c\end{array}$ & 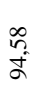 & है & $\begin{array}{l}\text { B. } \\
\text { in }\end{array}$ & oे & 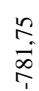 \\
\hline Kyiv & $\begin{array}{l}8 \\
8 \\
\infty \\
\infty \\
\infty\end{array}$ & $\begin{array}{l}\infty \\
\infty \\
\sigma \\
\sigma\end{array}$ & 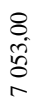 & $\begin{array}{l}\frac{8}{1} \\
\text { ते } \\
\text { D. }\end{array}$ & $\begin{array}{l}8 \\
8 \\
\text { fid } \\
\end{array}$ & 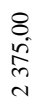 & $\begin{array}{l}n \\
\text { in } \\
\infty\end{array}$ &  & $\overrightarrow{0}$ & $\cong$ & $\begin{array}{l}8 \\
\text { - } \\
\infty \\
\infty\end{array}$ \\
\hline Kirovohrad & $\begin{array}{l}n \\
\text { o } \\
o \\
b \\
b\end{array}$ & $\begin{array}{l}\stackrel{8}{0} \\
\dot{6}\end{array}$ & $\begin{array}{l}\stackrel{n}{\circ} \\
\stackrel{n}{n} \\
\text { s. }\end{array}$ & $\frac{8}{8}$ & $\begin{array}{l}\text { 足 } \\
\text { s. } \\
\text { nn }\end{array}$ & 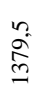 & $\begin{array}{l}\infty \\
\infty \\
\infty \\
\infty \\
\infty\end{array}$ & $\begin{array}{l}50 \\
8 \\
0\end{array}$ & त̂. & $\stackrel{\text { In }}{=}$ & $\begin{array}{l}\bumpeq \\
\sim \\
\infty \\
\infty\end{array}$ \\
\hline Luhansk & $\underset{\substack{n \\
\stackrel{n}{\infty}}}{\stackrel{n}{\infty}}$ & $\begin{array}{l}\delta \\
=\end{array}$ & $\begin{array}{l}8 \\
\stackrel{8}{+} \\
\stackrel{+}{d} \\
\sim\end{array}$ & 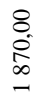 & 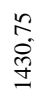 & $\begin{array}{l}n \\
\stackrel{8}{\circ} \\
\stackrel{0}{0}\end{array}$ & $\begin{array}{l}8 \\
\text { ర }\end{array}$ & $\begin{array}{l}\overrightarrow{2} \\
\frac{\sigma}{2}\end{array}$ & $\begin{array}{l}\underset{\infty}{+} \\
\text {. }\end{array}$ & $\stackrel{2}{ }$ & $\begin{array}{l}8 \\
\stackrel{8}{+} \\
\end{array}$ \\
\hline Lviv & $\begin{array}{l}n \\
\tilde{d} \\
\text { d }\end{array}$ & 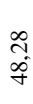 & $\begin{array}{l}\text { a } \\
\text { o } \\
0 \\
\Xi\end{array}$ & 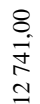 & $\begin{array}{l}\text { in } \\
\text { d } \\
\text { dn }\end{array}$ & $\begin{array}{l}n \\
\infty \\
\infty \\
i\end{array}$ & \begin{tabular}{l}
$\stackrel{0}{2}$ \\
\multirow{8}{\circ}{}
\end{tabular} & $\begin{array}{l}8 \\
8 \\
8\end{array}$ & $\begin{array}{l}\text { in } \\
\text { in }\end{array}$ & $\delta$ & \begin{tabular}{l} 
a \\
$\hat{s}$ \\
\multirow{a}{a}{}
\end{tabular} \\
\hline Mykolaiv & $\begin{array}{l}\text { त̂ } \\
\text { ه్ } \\
\text { ơ }\end{array}$ & $\begin{array}{l}J \\
\text { ले } \\
\text { f }\end{array}$ & 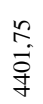 & $\begin{array}{l}8 \\
\text { in } \\
n \\
m \\
m\end{array}$ & $\stackrel{n}{ \pm}$ & $\begin{array}{l}\text { İ } \\
\stackrel{\vec{J}}{\mathcal{I}}\end{array}$ & $\begin{array}{c}m \\
\dot{m}\end{array}$ & $\stackrel{n}{=}$ & ㄱ. & $\stackrel{\text { II }}{=}$ & 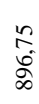 \\
\hline Odesa & $\frac{n}{\vec{I}}$ & $\frac{ \pm}{g}$ & 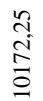 & $\begin{array}{l}8 \\
8 \\
0 \\
0 \\
a\end{array}$ & 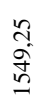 & مَ & $\stackrel{\substack{\infty \\
\infty}}{\widehat{\infty}}$ & $\overbrace{\infty}^{\infty}$ & 哭 & 寓 & $\begin{array}{l}\text { an } \\
\text { f̊ }\end{array}$ \\
\hline Poltava & 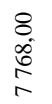 & ते & $\begin{array}{l}8 \\
8 \\
\frac{1}{6} \\
6\end{array}$ & 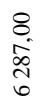 & 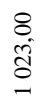 & $\frac{8}{\dot{\alpha}}$ & $\begin{array}{l}\infty \\
\infty \\
\infty\end{array}$ & $\begin{array}{l}\hat{\alpha} \\
\dot{\infty}\end{array}$ & $\begin{array}{l}0 \\
\dot{\gamma} \\
\dot{\gamma}\end{array}$ & s. & $\begin{array}{l}8 \\
\infty \\
\infty \\
q\end{array}$ \\
\hline
\end{tabular}


Continuation Table 1

\begin{tabular}{|c|c|c|c|c|c|c|c|c|c|c|c|}
\hline 1 & 2 & 3 & 4 & $\begin{array}{l}5 \\
\end{array}$ & 6 & 7 & 8 & 9 & 10 & 11 & 12 \\
\hline Rivne & $\begin{array}{l}8 \\
\text { s. } \\
\text { n } \\
\text { in }\end{array}$ & $\begin{array}{l}\bar{m} \\
\vdots \\
q\end{array}$ & $\begin{array}{l}n \\
\infty \\
o \\
\sigma \\
\sigma\end{array}$ & 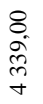 & $\begin{array}{l}\frac{n}{5} \\
i f\end{array}$ & $\begin{array}{l}8 \\
\stackrel{\therefore}{a}\end{array}$ & $\frac{m}{\sigma}$ & $\begin{array}{l}n \\
\text { n. } \\
\infty\end{array}$ & $\underset{\dot{m}}{\stackrel{+}{m}}$ & $\exists$ & $\begin{array}{l}n \\
\text { à } \\
\end{array}$ \\
\hline Sumy & $\begin{array}{l}8 \\
\text { i } \\
\text { in }\end{array}$ & $\begin{array}{l}3 \\
\text { of }\end{array}$ & 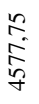 & $\begin{array}{l}8 \\
\text { i } \\
\text { } \\
\text { ma }\end{array}$ & $\begin{array}{l}7 \\
\text { a } \\
\text { f } \\
0\end{array}$ & $\begin{array}{l}8 \\
\stackrel{8}{+} \\
\text { I }\end{array}$ & $\begin{array}{c}= \\
\substack{\infty \\
\infty}\end{array}$ & 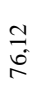 & $\begin{array}{l}\text { ते } \\
\text { ह̂ }\end{array}$ & $\stackrel{0}{=}$ & $\begin{array}{l}n \\
\text { ch } \\
\text { âे }\end{array}$ \\
\hline Ternopil & $\begin{array}{l}\stackrel{n}{2} \\
\text { mp } \\
\stackrel{f}{n}\end{array}$ & $\begin{array}{l}\text { do } \\
\text { in }\end{array}$ & $\begin{array}{l}n \\
\infty \\
\infty \\
n^{2}\end{array}$ & $\begin{array}{l}8 \\
\text { s. } \\
\text { d } \\
\text { in } \\
\text { n. }\end{array}$ & $\begin{array}{l}\text { ñ } \\
\text { D. } \\
m\end{array}$ & $\begin{array}{l}n \\
\infty \\
\infty \\
\infty \\
\infty\end{array}$ & $\begin{array}{l}n \\
n \\
n\end{array}$ & 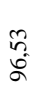 & $=$ & ô & $\begin{array}{l}n \\
\frac{n}{1} \\
\frac{1}{1}\end{array}$ \\
\hline Kharkiv & $\begin{array}{l}\text { a } \\
\text { o } \\
\text { o } \\
\text { ơ }\end{array}$ & $\begin{array}{l}8 \\
\dot{H} \\
\text { in }\end{array}$ & 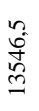 & 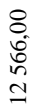 & $\begin{array}{l}n \\
\infty \\
\infty \\
\stackrel{0}{\simeq}\end{array}$ & $\begin{array}{l}\text { ते } \\
\text { ลे } \\
\text { ते }\end{array}$ & 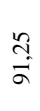 & \begin{tabular}{l}
$n$ \\
\multirow{\infty}{\infty}{} \\
+
\end{tabular} & $\begin{array}{l}\text { त̂ } \\
\text { of }\end{array}$ & $\stackrel{\infty}{\circ}$ & 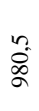 \\
\hline Kherson & 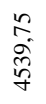 & $\begin{array}{l}\text { in } \\
\text { fi }\end{array}$ & \begin{tabular}{l} 
ra \\
\multirow{2}{*}{$+\frac{1}{q}$}
\end{tabular} & $\begin{array}{l}8 \\
\text { i } \\
\text { d } \\
\text { nat }\end{array}$ & \begin{tabular}{l}
$n$ \\
\multirow{\sigma}{\sigma}{} \\
$\sigma$
\end{tabular} &  & $\frac{n}{\infty}$ & $\underset{F}{F}$ & 苞 & 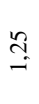 & 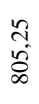 \\
\hline Khmelnitsky & $\begin{array}{l}n \\
\stackrel{2}{0} \\
\hat{\sigma} \\
i n\end{array}$ & $\begin{array}{l}\bar{b} \\
\dot{f}\end{array}$ & 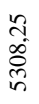 & $\begin{array}{l}8 \\
+ \\
+ \\
0 \\
+\end{array}$ & $\begin{array}{l}n \\
\text { no } \\
o\end{array}$ & $\begin{array}{l}n \\
2 \\
\infty \\
\infty\end{array}$ & $\begin{array}{l}\hat{b} \\
\sigma\end{array}$ & $\begin{array}{l}\vec{n} \\
+ \\
+\end{array}$ & ले & $\stackrel{\infty}{\circ}$ & \begin{tabular}{l} 
वे \\
\multirow{f}{f}{}
\end{tabular} \\
\hline Cherkasy & 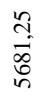 & $\begin{array}{l}\sqrt{2} \\
\text { f }\end{array}$ & $\begin{array}{l}n \\
\text { s. } \\
\approx \\
n\end{array}$ & 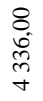 & $\begin{array}{l}n \\
\text { ?. } \\
+ \\
+\end{array}$ & $\begin{array}{l}\text { a } \\
\text { w } \\
\text { s. } \\
\end{array}$ & $\begin{array}{l}f \\
\dot{\sigma}\end{array}$ &  & $\begin{array}{l}\underset{f}{+} \\
\dot{f}\end{array}$ & $\stackrel{-1}{=}$ & $\begin{array}{l}n \\
\hat{0} \\
0 \\
0\end{array}$ \\
\hline Chernivtsi & $\begin{array}{l}8 \\
\circ \\
\infty \\
\infty \\
+\end{array}$ & 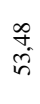 & $\begin{array}{l}\text { 年 } \\
\text { f }\end{array}$ & $\begin{array}{l}\text { o } \\
\text { ij } \\
\text { in } \\
\text { in }\end{array}$ & $\begin{array}{l}n \\
n \\
n \\
n\end{array}$ &  & $\begin{array}{l}\infty \\
m_{0}^{2} \\
\sigma^{2}\end{array}$ & $\begin{array}{l}8 \\
8 \\
8\end{array}$ & $\begin{array}{l}\text { 占 } \\
\text { in }\end{array}$ & مे & in \\
\hline Chernihiv & $\begin{array}{l}n \\
n \\
\infty \\
0 \\
0 \\
n\end{array}$ & $\begin{array}{l}\tilde{N} \\
\stackrel{\delta}{+\infty}\end{array}$ & 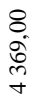 & $\begin{array}{l}8 \\
+\dot{d}^{\circ} \\
\text { m }\end{array}$ & $\begin{array}{l}\frac{2}{0} \\
\hat{\delta}\end{array}$ & 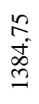 & $\begin{array}{l} \pm \\
0 \\
0 \\
0\end{array}$ & 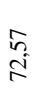 & $\begin{array}{l}\vec{j} \\
\dot{f}\end{array}$ & $\stackrel{\cong}{\rightleftarrows}$ & $\begin{array}{l}8 \\
i \\
i\end{array}$ \\
\hline Kyiv city &  & $\stackrel{2}{i}$ & $\begin{array}{l}\stackrel{n}{a} \\
\text { n. } \\
\stackrel{\infty}{\infty}\end{array}$ & $\begin{array}{l}8 \\
8 \\
0 \\
0 \\
0\end{array}$ & 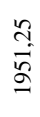 & $\begin{array}{l}8 \\
: \\
5 \\
0\end{array}$ & $\begin{array}{c}\hat{m} \\
\stackrel{2}{2}\end{array}$ & \begin{tabular}{l}
$\infty$ \\
$\infty$ \\
0 \\
\multirow{2}{R}{}
\end{tabular} & $\begin{array}{l}\infty \\
\text { s. } \\
\mathbf{b}^{\circ}\end{array}$ & $\stackrel{\cong}{=}$ & $\begin{array}{l}\text { a } \\
\text { â } \\
\text { d }\end{array}$ \\
\hline
\end{tabular}


Table 2

Medical positions in the regions of Ukraine, 2018

\begin{tabular}{|c|c|c|c|c|c|c|c|c|c|c|c|}
\hline Region & 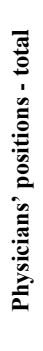 & 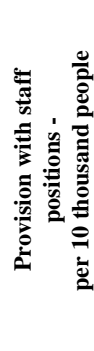 & 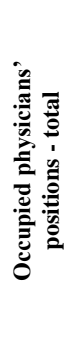 & 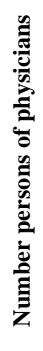 & 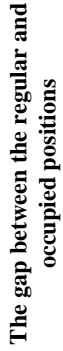 & 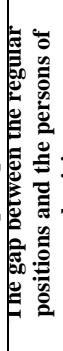 &  & 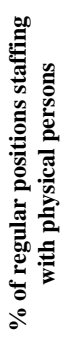 & 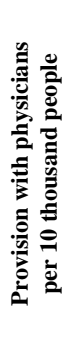 & 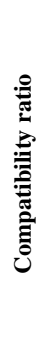 & 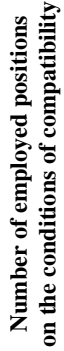 \\
\hline 1 & 2 & 3 & 4 & 5 & 6 & 7 & 8 & 9 & 10 & 11 & 12 \\
\hline Ukraine & 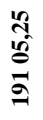 & $\begin{array}{l}F \\
i f\end{array}$ & 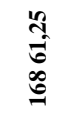 & 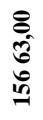 & 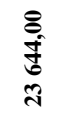 & 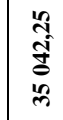 & $\underset{\infty}{\infty}$ & $\frac{\pi}{\infty}$ & m. & $\stackrel{s}{=}$ & $\begin{array}{l}\text { तू } \\
\text { ले } \\
\text { ले }\end{array}$ \\
\hline Vinnitsa & 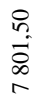 & $\begin{array}{l}\tilde{1} \\
\text { sं }\end{array}$ & $\frac{8}{\grave{~}}$ & $\begin{array}{l}8 \\
\vdots \\
0 \\
1\end{array}$ & $\begin{array}{l}\stackrel{0}{n} \\
\infty \\
\infty \\
\infty\end{array}$ & $\begin{array}{l}\text { ஜn } \\
\text { o̊ } \\
8\end{array}$ & $\begin{array}{l}\vec{N} \\
\infty \\
\infty\end{array}$ & $\frac{\hat{\sigma}}{a}$ & $\underset{⿱ 丶 万}{\stackrel{+}{f}}$ & $\hat{\sigma}$ & $\begin{array}{l}8 \\
+ \\
+ \\
1\end{array}$ \\
\hline Volyn & $\begin{array}{l}8 \\
\infty \\
\infty \\
n \\
+\end{array}$ & $\begin{array}{l}n \\
\infty \\
\tilde{f}\end{array}$ & $\begin{array}{l}n \\
\stackrel{n}{2} \\
\stackrel{2}{n}\end{array}$ & $\begin{array}{l}8 \\
\frac{8}{1} \\
m\end{array}$ & 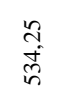 & $\frac{8}{\bar{\infty}}$ & $\begin{array}{l}\text { त) } \\
\infty \\
\infty\end{array}$ & $\begin{array}{l}\text { oे } \\
\text { i }\end{array}$ & $\begin{array}{l}8 \\
\text { s. } \\
\text { D. }\end{array}$ & $\stackrel{5}{0}$ & $\begin{array}{l}\frac{n}{6} \\
\frac{6}{2}\end{array}$ \\
\hline Dnipropetrovsk & 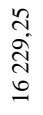 & $\begin{array}{l}\hat{\sigma} \\
\therefore \\
\text { in }\end{array}$ & $\begin{array}{l}8 \\
8 \\
8 \\
\pm\end{array}$ & $\begin{array}{l}8 \\
i \\
\Varangle \\
\simeq\end{array}$ & 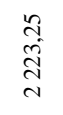 & $\begin{array}{l}\stackrel{2}{2} \\
\frac{1}{\infty} \\
m\end{array}$ & $\begin{array}{l}\text { లి } \\
\text { రి. } \\
\infty\end{array}$ & $\stackrel{\infty}{\stackrel{\infty}{\circ}}$ & $\begin{array}{l}n \\
\stackrel{n}{\infty} \\
\infty\end{array}$ & $\stackrel{m}{=}$ & 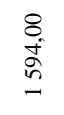 \\
\hline Donetsk & $\begin{array}{l}\stackrel{n}{n} \\
\tilde{n} \\
\infty \\
\infty\end{array}$ & $\begin{array}{l}\text { m. } \\
\text { fr }\end{array}$ & \begin{tabular}{l}
$n$ \\
\multirow{6}{0}{} \\
\multirow{1}{*}{} \\
0
\end{tabular} & $\begin{array}{l}8 \\
\text { i } \\
i n\end{array}$ & $\begin{array}{l}\stackrel{7}{=} \\
= \\
-\end{array}$ & $\begin{array}{l}0 \\
\infty \\
\infty \\
\infty \\
\text { N }\end{array}$ & $\frac{N}{\hat{\infty}}$ & $\frac{0}{8}$ &  & กิ & $\begin{array}{l}\text { ป̃ } \\
\text { ป } \\
\text { }\end{array}$ \\
\hline 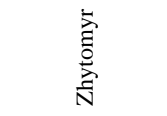 & 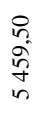 & $\begin{array}{l}\bar{\nabla} \\
\dot{f}\end{array}$ & $\begin{array}{l}\stackrel{2}{\sigma} \\
\stackrel{\infty}{\infty} \\
+\end{array}$ & $\begin{array}{l}8 \\
\stackrel{+}{+} \\
\stackrel{+}{+} \\
+\end{array}$ & $\begin{array}{l}\text { त̂ } \\
\infty \\
\text { ర్ర }\end{array}$ & $\begin{array}{l}\stackrel{n}{2} \\
\stackrel{2}{2} \\
-\end{array}$ & $\begin{array}{l}\stackrel{+}{+} \\
\infty \\
\infty\end{array}$ & $\begin{array}{l}8 \\
\stackrel{1}{*}\end{array}$ & $\begin{array}{l}\stackrel{m}{\tilde{m}} \\
\dot{m}\end{array}$ & $\Xi$ & $\frac{n}{n}$ \\
\hline 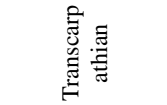 & 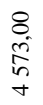 & $\begin{array}{l}\text { fó } \\
\text { চ̊n }\end{array}$ & $\begin{array}{l}0 \\
\vdots \\
8 \\
0 \\
+\end{array}$ & \begin{tabular}{l}
8 \\
8 \\
$\infty$ \\
\multirow{+}{+}{} \\
+
\end{tabular} & 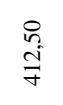 & $\begin{array}{l}8 \\
i n \\
0\end{array}$ & $\begin{array}{l}\infty \\
\stackrel{8}{\Omega}\end{array}$ & के & $\frac{n}{n}$ & o. & 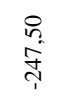 \\
\hline
\end{tabular}


Continuation Table 2

\begin{tabular}{|c|c|c|c|c|c|c|c|c|c|c|c|}
\hline 1 & 2 & 3 & 4 & 5 & 6 & 7 & 8 & 9 & 10 & 11 & 12 \\
\hline Zaporizhia & 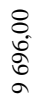 &  & $\begin{array}{l}\gamma \\
\tilde{\gamma} \\
\partial \\
\infty \\
\infty\end{array}$ & 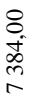 & 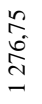 & $\begin{array}{l}8 \\
\text { i } \\
\stackrel{m}{N}\end{array}$ & $\begin{array}{l}\infty \\
\infty \\
\infty \\
\infty \\
\infty\end{array}$ & $\begin{array}{l}0 \\
\text { é }\end{array}$ & $\begin{array}{l}\bar{m} \\
\dot{f}\end{array}$ & $\stackrel{\Xi}{\Xi}$ & 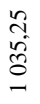 \\
\hline $\begin{array}{l}\text { Ivano- } \\
\text { Frankivsk }\end{array}$ & $\begin{array}{l}8 \\
\infty \\
\dot{f}\end{array}$ & $\begin{array}{l}\stackrel{m}{f} \\
\dot{f}\end{array}$ & $\begin{array}{l}0 \\
n \\
\infty \\
\infty \\
\infty \\
0\end{array}$ & 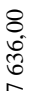 & $\begin{array}{l}\text { n. } \\
\text { हैं } \\
\text { n. }\end{array}$ & $\begin{array}{l}8 \\
\frac{\infty}{7} \\
\frac{1}{10}\end{array}$ & $\begin{array}{l}n \\
\infty \\
i \\
\text { a }\end{array}$ & $\begin{array}{l}\text { dे } \\
\text { ¿े }\end{array}$ & $\begin{array}{l}\text { ה } \\
\text { n. }\end{array}$ & : & 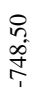 \\
\hline Kyiv & $\begin{array}{l}\text { त̂ } \\
\text { ָี } \\
\infty \\
\infty\end{array}$ & 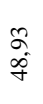 & $\begin{array}{l}n \\
\\
0 \\
\infty \\
\infty \\
0\end{array}$ & $\begin{array}{l}8 \\
+\mathbb{J} \\
\text { J }\end{array}$ &  & $\begin{array}{l}\text { r } \\
\infty \\
\infty \\
\sim \\
\sim\end{array}$ & $\begin{array}{l}\infty \\
\infty \\
i\end{array}$ & $\frac{a}{\hat{i}}$ & $\begin{array}{l}\text { ले } \\
\text { है } \\
\text { है }\end{array}$ & $\exists$ & 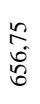 \\
\hline Kirovohrad & 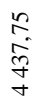 & \begin{tabular}{l} 
ते \\
\multirow{\gamma}{\gamma}{}
\end{tabular} & $\begin{array}{l}n \\
n \\
\infty \\
\infty \\
\infty \\
m\end{array}$ & $\begin{array}{l}8 \\
\text { d. } \\
\text { d. }\end{array}$ & $\begin{array}{l}\text { r. } \\
\text { ș }\end{array}$ &  & तై & $\begin{array}{l}\text { Oे. } \\
\text { बें }\end{array}$ & $\begin{array}{l}\tilde{b} \\
\text { iు }\end{array}$ & $\stackrel{\text { an }}{=}$ & $\begin{array}{l}8 \\
\text { no } \\
\frac{1}{2}\end{array}$ \\
\hline Luhansk & $\frac{n}{\frac{n}{n}}$ & 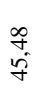 & 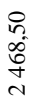 & $\begin{array}{l}8 \\
\text { nू. } \\
\text { n. }\end{array}$ & $\begin{array}{l}8 \\
\text { \&. } \\
0 \\
0\end{array}$ & 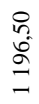 & $\begin{array}{c}m \\
\infty \\
\infty \\
\infty\end{array}$ & $\begin{array}{l}\text { ô } \\
\text { î }\end{array}$ & $\begin{array}{l}\overline{\text { d }} \\
\text { ì }\end{array}$ &  & $\begin{array}{l}\text { n } \\
\text { mi }\end{array}$ \\
\hline Lviv & 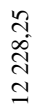 & 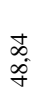 & 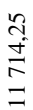 & 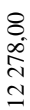 & $\begin{array}{l}8 \\
\dot{+} \\
\text { ti }\end{array}$ & $\begin{array}{l}\stackrel{n}{a} \\
\dot{q}\end{array}$ & $\begin{array}{l}\infty \\
\infty \\
\alpha\end{array}$ & $\begin{array}{l}\vec{f} \\
8 \\
8\end{array}$ & $\begin{array}{l}\text { to } \\
\dot{g}\end{array}$ & $\stackrel{\alpha}{\alpha}$ & 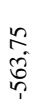 \\
\hline Mykolaiv & $\begin{array}{l}\text { r } \\
\text { î } \\
\stackrel{+}{+}\end{array}$ & $\begin{array}{l}\hat{\infty} \\
\vec{f}\end{array}$ & $\begin{array}{l}n \\
\text { ma } \\
\text { ma } \\
\dot{\gamma}\end{array}$ & $\begin{array}{l}8 \\
\infty \\
\infty \\
\text { ते } \\
m\end{array}$ & $\begin{array}{l}8 \\
b \\
b\end{array}$ & 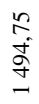 & $\begin{array}{l}\infty \\
0 \\
\infty \\
\infty\end{array}$ & $\begin{array}{l}\text { f } \\
\text { go }\end{array}$ & 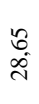 & $\underset{\sim}{\sim}$ & $\begin{array}{l}n \\
\text { c. } \\
\infty \\
\infty\end{array}$ \\
\hline Odesa & 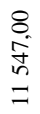 & $\underset{\substack{+ \\
\text { do }}}{ }$ & $\begin{array}{l}\text { â } \\
\text { s. } \\
\text { a } \\
\end{array}$ & $\begin{array}{l}8 \\
- \\
\infty \\
\infty \\
\sigma\end{array}$ & $\begin{array}{l}2 \\
\text { م. } \\
2\end{array}$ & $\begin{array}{l}8 \\
\dot{8} \\
0\end{array}$ & $\begin{array}{l}2 \\
\dot{0} \\
\dot{\infty}\end{array}$ & $\begin{array}{l}5 \\
\text { న } \\
\text { ch }\end{array}$ & $\begin{array}{l}\text { qu } \\
\text { gे }\end{array}$ & $\delta_{-}^{1}$ & $\begin{array}{l}\text { ते } \\
\text { ते }\end{array}$ \\
\hline Poltava & 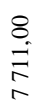 & $\begin{array}{l}n \\
\text { in }\end{array}$ & $\begin{array}{l}\text { in } \\
\text { f } \\
0 \\
0\end{array}$ & $\begin{array}{l}8 \\
\text { तิ } \\
\text { రิ }\end{array}$ &  & $\begin{array}{l}8 \\
\stackrel{8}{\Xi} \\
\end{array}$ & $\begin{array}{l}0 \\
h_{0} \\
\infty \\
\infty\end{array}$ & $\underset{-1}{\infty}$ & $\frac{\infty}{v^{\prime}}$ & $\stackrel{-}{-}$ & $\begin{array}{l}\text { rn } \\
\text { i. } \\
\infty \\
m\end{array}$ \\
\hline Rivne & $\begin{array}{l}8 \\
\text { ôे } \\
\text { in } \\
\text { n. }\end{array}$ & $\frac{9}{\dot{q}}$ & $\begin{array}{l}n \\
0 \\
0 \\
0\end{array}$ & $\begin{array}{l}8 \\
\text { in } \\
\text { m } \\
+\end{array}$ & $\begin{array}{l}0 \\
\text { in } \\
\text { sin } \\
\text { in }\end{array}$ & $\begin{array}{l}8 \\
8 \\
\infty \\
\infty\end{array}$ & $\begin{array}{l}a \\
\infty \\
\infty\end{array}$ & D. & $\begin{array}{l} \pm \\
\text { a } \\
\text { m }\end{array}$ & $\stackrel{5}{=}$ & in \\
\hline
\end{tabular}


Continuation Table 2

\begin{tabular}{|c|c|c|c|c|c|c|c|c|c|c|c|}
\hline 1 & 2 & 3 & 4 & 5 & 6 & 7 & 8 & 9 & 10 & 11 & 12 \\
\hline Sumy & $\begin{array}{l}n \\
\text { n. } \\
\infty \\
\text { in }\end{array}$ & $\stackrel{7}{\stackrel{0}{\sigma}}$ & 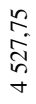 & $\begin{array}{l}8 \\
0 \\
0 \\
0 \\
+\end{array}$ & 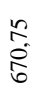 & 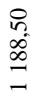 & $\frac{0}{\infty}$ & $\frac{ \pm}{i}$ & $\frac{6}{\sqrt[m]{m}}$ & $\stackrel{9}{=}$ & $\begin{array}{l}\frac{c}{s} \\
\frac{n}{n}\end{array}$ \\
\hline Ternopil & $\begin{array}{l}n \\
n \\
f \\
n \\
n\end{array}$ & $\begin{array}{l}\text { సิ } \\
\text { nิ }\end{array}$ & 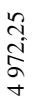 & $\begin{array}{l}8 \\
\frac{8}{n} \\
\frac{1}{n} \\
\end{array}$ & 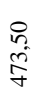 & 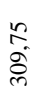 & $\vec{m}$ & $\begin{array}{l}\bar{m} \\
\dot{\alpha}\end{array}$ & $\begin{array}{l}\text { N. } \\
\text { gे }\end{array}$ & s. & $\begin{array}{l}2 \\
\hat{\tilde{\beta}} \\
\frac{1}{1}\end{array}$ \\
\hline Kharkiv & 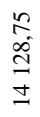 & $\Rightarrow$ & 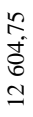 & $\begin{array}{l}\frac{8}{0} \\
= \\
=\end{array}$ & \begin{tabular}{l}
8 \\
8 \\
\multirow{4}{*}{} \\
$=$
\end{tabular} & 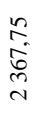 & $\begin{array}{l}\bar{\lambda} \\
\stackrel{\infty}{0}\end{array}$ & $\underset{\infty}{\stackrel{\sim}{\sim}}$ & $\begin{array}{l}\bar{N} \\
\dot{f}\end{array}$ & $\stackrel{5}{s}$ & 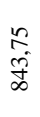 \\
\hline Kherson & $\begin{array}{l}\text { n } \\
\text { î } \\
\text { on } \\
\text { then }\end{array}$ & $\begin{array}{l}\frac{b}{f} \\
\text { s. }\end{array}$ & $\begin{array}{l}\text { ra } \\
\text { o } \\
\infty \\
\infty \\
m\end{array}$ & $\begin{array}{l}8 \\
0 \\
\stackrel{0}{=}\end{array}$ & $\begin{array}{l}\text { a } \\
\text { ț }\end{array}$ & 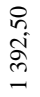 & $\begin{array}{l}\infty \\
\overbrace{0} \\
\infty\end{array}$ & i. & 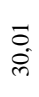 & $\stackrel{\text { I }}{=}$ & $\begin{array}{l}\text { הి } \\
\infty \\
\infty \\
\infty\end{array}$ \\
\hline Khmelnitsky & $\begin{array}{l}\text { D. } \\
\text { ô } \\
\text { in }\end{array}$ & $\begin{array}{l}n \\
m \\
y^{2}\end{array}$ & $\begin{array}{l}n \\
\hat{i} \\
\text { s. } \\
\text { n. }\end{array}$ & $\frac{8}{\frac{\dot{m}}{\sigma}}$ & $\begin{array}{l}n \\
\text { r. } \\
i n \\
\text { in }\end{array}$ & 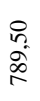 & $\begin{array}{l}\text { ते } \\
\text { \&̊ }\end{array}$ & $\begin{array}{l}\text { స్ } \\
\text { Sీ }\end{array}$ & $\begin{array}{l}\text { aे } \\
\text { iे }\end{array}$ & $\stackrel{2}{0}$ & $\begin{array}{l}\stackrel{n}{\pi} \\
\stackrel{\pi}{\pi}\end{array}$ \\
\hline Cherkasy & $\begin{array}{l}n \\
\text { af } \\
\text { ḋ } \\
n\end{array}$ & $\begin{array}{l}\hat{R} \\
\stackrel{f}{f}\end{array}$ & $\begin{array}{l}\text { n. } \\
\text { \&. } \\
\text { in }\end{array}$ & $\begin{array}{l}8 \\
\stackrel{8}{0} \\
\underset{f}{f}\end{array}$ & $\begin{array}{l}\text { yे } \\
\infty \\
0 \\
0\end{array}$ & 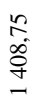 & $\begin{array}{l}\overline{0} \\
\dot{\infty}\end{array}$ & $\begin{array}{l}\check{a} \\
\stackrel{+}{\sim}\end{array}$ & $\begin{array}{l}\text { of } \\
\text { s. } \\
m\end{array}$ & $\stackrel{2}{\beth}$ & $\begin{array}{l}8 \\
\overbrace{}^{\circ} \\
2\end{array}$ \\
\hline Chernivtsi & 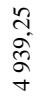 & $\begin{array}{l}\infty \\
\text { iे } \\
\dot{f}\end{array}$ & $\begin{array}{l}2 \\
\hat{2} \\
\hat{\delta} \\
+\end{array}$ & $\begin{array}{l}8 \\
\text { î } \\
\text { in }\end{array}$ & $\begin{array}{l}\text { की } \\
\text { के }\end{array}$ & $\begin{array}{l}n \\
\text { ż } \\
\underline{y}\end{array}$ & $\begin{array}{l}\frac{n}{2} \\
+ \\
\dot{f}\end{array}$ & $\begin{array}{l}\text { aे } \\
\text { si }\end{array}$ & $\begin{array}{l}0 \\
\text { s. } \\
n^{\prime \prime}\end{array}$ & $\delta$ &  \\
\hline Chernihiv & \begin{tabular}{l}
$n$ \\
2 \\
\multirow{+}{\infty}{} \\
+
\end{tabular} & $\begin{array}{l}\infty \\
\infty \\
o \\
o\end{array}$ & 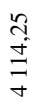 & $\begin{array}{l}8 \\
\text { î } \\
\text { ñ }\end{array}$ & $\begin{array}{l}\text { के } \\
8 \\
8\end{array}$ & $\begin{array}{l}\text { r } \\
\text { di } \\
\underline{m}\end{array}$ & $\begin{array}{l}\text { fo } \\
\text { s. }\end{array}$ & î & $\stackrel{I}{m}$ & $=$ & $\begin{array}{l}\text { â } \\
\text { İ } \\
\text { the }\end{array}$ \\
\hline Kyiv city & $\begin{array}{l}\text { ru } \\
\text { ḋ } \\
0 \\
0\end{array}$ & $\begin{array}{l}\stackrel{8}{\circ} \\
0 \\
0\end{array}$ & $\begin{array}{l}\text { D. } \\
8 \\
\text { N } \\
=\end{array}$ & $\begin{array}{l}0 \\
+ \\
i \\
\text { in }\end{array}$ & 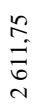 & $\begin{array}{l}\text { तr } \\
0 \\
0 \\
0 \\
\forall\end{array}$ & 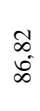 & $\begin{array}{l}\text { مे } \\
\text { gे }\end{array}$ & $\begin{array}{c}\hat{a} \\
\text { nो }\end{array}$ & 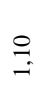 & $\begin{array}{l}0 \\
\text { o. } \\
\text { gे }\end{array}$ \\
\hline
\end{tabular}


The data on the AR Crimea, Sevastopol and temporarily occupied territories of Donetsk and Lugansk regions were not taken into account in the study.

The undertaken analysis of the data given in Table 1 indicates that in terms of regions of the country the indicators of provision of the population with doctors' positions in 2014 had significant differences. Thus, the highest rates of provision by doctors' positions were registered in Kiev (71.19 per 10 thousand people), Zaporizhia (55.61) Kharkiv (54.66), Poltava (53.90), Ivano-Frankivsk (52.83), Chernivtsi (53.48) regions. The lowest rates of provision by doctors' positions were registered in Lugansk (17.02), Donetsk (18.69), Transcarpathian (36.44), Kherson (42.57), Mykolaiv (42.34), Volyn (42.84) regions. The maximum difference reaches 4.18 times. In general, there were registered 194920.5 positions of physicians with an average level of provision 45.59 per 10 thousand people in health care system of Ukraine. In 2014, the health care system of Ukraine employed 159,969.00 physicians with 34951.5 difference between staffing and physical persons of doctors. At the same time, staffing of regular positions taking into account the compatibility in health care system of Ukraine composed $89.39 \%$ with difference from $62.06 \%$ in Lugansk region to $96.76 \%$ in Lviv region. The highest compatibility ratios were registered in Donetsk (1.29), Mykolaiv (1.26) and Kirovohrad, Luhansk, Mykolaiv (1.25) regions. In total, the health care system of Ukraine there are 14262.00 physicians positions staffed on the conditions of compatibility. Most medical positions occupied as part-time are found in Kyiv (2125.75), Dnipropetrovsk (2107.75) and Donetsk (1473.75) regions. Staffing of regular positions by individuals in health care system of Ukraine composed $82.07 \%$ with difference from 49.59\% in Lugansk region to $100 \%$ in Transcarpathian, Lviv, and Chernivtsi regions.

Further, in Table 2 the data on the provision with physicians in 2018 are given.

Analysis of data given in Table 2 indicates that in 2018 in health care system of Ukraine there were registered 191905.25 regular positions of doctors with the level of provision 45.71 per 10 thousand people. In comparison to 2014 the number of regular positions decreased by 3015.25, the level of their availability by 0.12 per 10 thousand people. In terms of regions, the differences in the level of provision with regular doctors' positions by 1.87 times were denoted: from 36.47 in Transcarpathian region to 68.09 in Kyiv.

The gap between the staff posts and individuals of doctors in 2018 reached 35042.25 (in 2014 - 34951.5). The largest shortage of doctors was 
registered in Kyiv (4108.25), Dnipropetrovsk (3817.25), Donetsk (2833.50), Kyiv (2398.25), Kharkiv (2367.75) regions. The surplus of doctors is registered in Ivano-Frankivsk (218), Lviv (50), Chernivtsi (122) oblasts.

The level of regular positions staffing, taking into account the compatibility, reached $87.68 \%$, and the level of staffing by individuals amounted to $81.74 \%$ (in 2014-82.07\%). In terms of administrative territories, the indicated index is substantially different: from $82.07 \%$ in Luhansk to $100 \%$ in Ivano-Frankivsk, Lviv and Chernivtsi regions.

Provision with physical persons of doctors in health care system of Ukraine composes 37.36 per 10 thousand people (in 2014 - 37.41). In terms of administrative territories, the difference is 1.98 times: from 28.21 in Luhansk to 55.72 in Ivano-Frankivsk region.

11398.25 of physicians' posts were occupied on the conditions of compatibility in 2018 (14 262.00 in 2014). The coefficient of compatibility in health care system of Ukraine in 2018 amounted to 1.07.

Next, we analyzed the structure of physicians by the types of medical care. In 2018 the share of physicians of specialized medical care was 79\%, primary medical care $-18 \%$, and emergency medical care $-4 \%$. The analysis conducted allowed to define that the structure of physicians by the types of medical care was almost unchanged over the past 20 years. It should be noted that in the European Union countries the indicated index is 1:3.

It was found in the course of study that in 2018 two-thirds of regular positions of doctors $(65.5 \%)$ belonged to hospitals and only one third $(34.5 \%)$ - to outpatient health care institutions. In EU countries hospitals registered $57 \%$ of the doctors' positions. It was also defined that for the period from 2014 to 2018 the rate of precinct therapists' and precinct pediatricians' positions decrease averaged $12 \%$ and $3 \%$ per year respectively. At the same time, the average annual rate of growth of the number of family physicians is registered at 5\% level. In 2018, the provision of family by doctors amounted to 4.8 per 10 thousand people and in EU countries the indicated index is 7.8 .

Among the most numerous specialties in 2018 (provision of $0,65-2.4$ per 10 thousand population) were obstetricians-gynecologists, hospital therapists, surgeons, anesthesiologists, neurologists, hospital pediatricians, orthopediststraumatologists, roentgenologists, psychiatrists, ophthalmologists and otolaryngologists. The level of provision $0.29-0.64$ per 10 thousand population includes cardiologists, dermatologists, infectious diseases specialists, ultrasound physicians, phthisiatrists, oncologists, neonatologists, urologists, endocrinologist and specialists in functional diagnostics. To doctors with the level of provision $0.1-0.28$ per 10 thousand population belong medicolegal experts, 
physiotherapists, narcologists, pathologists, gastroenterology, endoscopists, rheumatologists (including children's cardio-rheumatologist), pulmonologists, nephrologists, specialists of sports medicine and radiologists. The least numerous specialties (level of provision less than 0.1 per 10 thousand population) include hematologists, transfusiologists, allergists, proctologists, psychotherapists, immunologists, nutritionists, sexologists, toxicologists and sanologues.

For the period from 2014 to 2018 the decrease in the provision by the doctors of the following specialties was registered: urologists, pulmonologists, neurologists, gastroenterologists, surgeons, psychiatrists, rheumatologists, obstetricians, gynecologists, otolaryngologists, transfusiologists, narcologists, dermatologists, ophthalmologists and sexologists, doctors of functional diagnostics, radiologists, psychotherapists, phthisiatrists, toxicologists, immunologists, physiotherapists, specialists of therapeutic sports medicine, hospital paediatricians, hospital therapists, nutritionists and sanologues.

During the same period the increase in the provision of the doctors of the following specialties was registered: cardiologists, nephrologists, endocrinologist, allergists, hematologists, neonatologists, ultrasonic diagnostics doctors, pathologists, infectious diseases specialists, medicolegal experts, anesthesiologists, orthopedists-traumatologists, endoscopy, proctologists and oncologists.

The provision of emergency doctors increased in $2014-2017$ by $0.2 \%$, but in 2018 the decrease of their provision by $1.9 \%$ was registered compared to the previous year rate of 0.98 per 10 thousand population. In 2018 the provision of dentists in Ukraine amounted to 4.0 per 10 thousand population.

For the period 2017-2018 the number of doctors in health care system of Ukraine decreased by 2737 people. Decrease in the number of physicians takes place mainly owing to doctors-stomatologists (45\% of total losses). In 2017-2018 the highest rates of the decrease in the number of doctors was registered in the western boundary regions (Rivne, Volyn, Lviv, IvanoFrankivsk and Transcarpathian), in the south (Mykolaiv and Kherson) and in the east (Dnipropetrovsk and Kharkiv oblasts).

Taking into account that $31 \%$ of population in Ukraine lives in rural areas we have studied the indices of provision of rural population by physicians. It was found that in $20185 \%$ of doctors worked in rural areas. The share of rural physicians ranged from $2 \%$ in Zaporizhia region to $13 \%$ in Transcarpathian and Cherkasy oblasts. The provision of rural population with doctors amounted to 6.6 per 10 thousand of rural population. 
In 2018 the share of pensioners among physicians composed 25\%. Most of the retired doctors work in Kyiv, Cherkasy, Kirovohrad, Mykolaiv, Kherson, Dnipropetrovsk and Donetsk regions.

\section{Provision with mid-level healthcare workers in terms of administrative territories}

At the beginning, we studied and analyzed the data about mid-level health workers by regions for 2014. The obtained data are shown in Table 3.

Analysis of the data given in Table 3 indicates that 360322.75 positions of mid-level medical workers were introduced in 2014 in health care system of Ukraine. Provision of the positions of mid-level medical workers amounted to 84.27 per 10 thousand population. The highest registed indices are registered in the following regions: Kiev (102.69), Sumska (100.77), Chernigov (108.27) region and Kyiv (101.17). The lowest registered indices were registered in the following regions: Lugansk (34.07), Donetsk (38.57) and Transcarpathian (74.25) regions. The maximum index difference was 3.18 times.

339042.5 positions of mid-level medical personnel were occupied in health care system. 21280.25 positions remained not occupied. The system employed 346191.00 mid-level medical workers. The shortage of mid-level health workers amounted to 14131 persons. The largest shortage of midlevel health workers was registered in Kyiv (6 589.25) and Dnipropetrovsk region (3 182.00). At the same time, in the following areas, mid-level medical workers did not work full time: Volyn, Zhytomyr, Transcarpathian, Ivano-Frankivsk, Lviv, Rivne, Khmelnytsky, Chernivtsi regions.

The data on mid-level medical workers for 2018 were studied and analyzed. The data are given in Table 4.

344161.25 positions of secondary medical workers were introduced in health care system of Ukraine in 2018. Level of provision of these posts amounted to 81.98 per 10 thousand population (84.27 in 2014). The difference of the index noted in terms of the regions of the country composed 1.44 times. The highest level of provision with the positions of mid-level medical personnel was registered in Kirovohrad (100.64), Sumy (101.25), Cherkassy (100.43), Chernihiv (104.75) regions. The lowest level of provision with the positions of mid-level medical personnel was registered in Transcarpathian (72.70) and Chernivtsi (80.71) regions. 
Table 3

Mid-level medical workers in the regions of Ukraine, 2014

\begin{tabular}{|c|c|c|c|c|c|c|c|c|}
\hline Region & 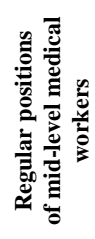 &  &  & 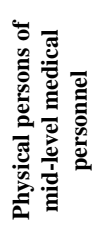 & 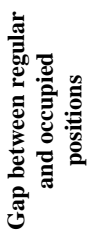 & 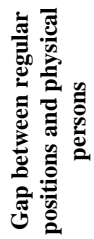 & 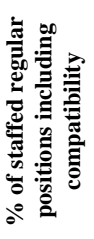 &  \\
\hline 1 & 2 & 3 & 4 & 5 & 6 & 7 & 8 & 9 \\
\hline Ukraine & $\begin{array}{l}n \\
\text { ñ } \\
\text { ô } \\
\text { हैं }\end{array}$ & $\begin{array}{l}\hat{~} \\
\text { fे }\end{array}$ & $\begin{array}{l}\text { ले } \\
\text { ले } \\
\text { ले }\end{array}$ & $\frac{8}{\frac{8}{2}}$ & 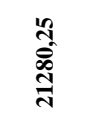 & $\frac{n}{\frac{m}{z}}$ & $\begin{array}{l}\hat{\theta} \\
\dot{\sigma}\end{array}$ & $\begin{array}{l}\stackrel{0}{0} \\
\stackrel{0}{\circ}\end{array}$ \\
\hline Vinnitsa & 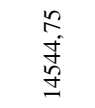 & $\overline{\hat{g}}$ & $\begin{array}{l}n \\
\stackrel{n}{2} \\
\stackrel{2}{=}\end{array}$ & $\begin{array}{l}8 \\
8 \\
2 \\
2\end{array}$ & 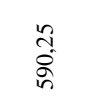 & 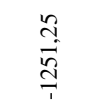 & $\begin{array}{l}\text { बे } \\
\text { ू̆ }\end{array}$ & $\begin{array}{l}0 \\
\stackrel{8}{0}\end{array}$ \\
\hline Volyn & $\begin{array}{l}8 \\
\text { i } \\
\text { on } \\
\sigma\end{array}$ & $\begin{array}{l}\text { ?े } \\
\stackrel{\infty}{\infty}\end{array}$ & $\begin{array}{l}\frac{n}{\sigma} \\
\bar{a}\end{array}$ & $\begin{array}{l}8 \\
\text { - } \\
0 \\
0\end{array}$ & $\begin{array}{l}n \\
8 \\
\Omega\end{array}$ & $\begin{array}{l}8 \\
\text { ते } \\
\stackrel{1}{1}\end{array}$ & 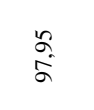 & $\begin{array}{l}\text { ते } \\
\text { J }\end{array}$ \\
\hline Dnipropetrovsk & $\begin{array}{l}8 \\
8 \\
\dot{1} \\
\sim \\
\text { ते }\end{array}$ & $\begin{array}{l}\text { ते } \\
\text { ळ }\end{array}$ & 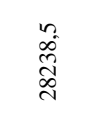 & $\begin{array}{l}8 \\
\text { i } \\
\hat{n} \\
0 \\
0\end{array}$ & $\frac{n}{n}$ & $\begin{array}{l}8 \\
i \\
\infty \\
\infty \\
m\end{array}$ & $\begin{array}{l}n \\
n \\
\kappa\end{array}$ & $\begin{array}{l}\hat{\infty} \\
\stackrel{\infty}{ }\end{array}$ \\
\hline Donetsk & 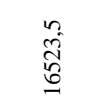 & $\begin{array}{l}n \\
\text { in } \\
\infty \\
\infty\end{array}$ & $\begin{array}{l}8 \\
8 \\
\infty \\
\infty \\
n\end{array}$ & $\begin{array}{l}8 \\
\bar{\Xi} \\
\pm \\
\pm\end{array}$ & $\begin{array}{l}\ddot{2} \\
\stackrel{2}{=}\end{array}$ & $\begin{array}{l}n \\
\text { त̃ } \\
\tilde{N}\end{array}$ & $\vec{n}$ & $\begin{array}{l}\text { qे } \\
\text { هे }\end{array}$ \\
\hline Zhytomyr & 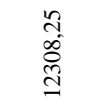 & 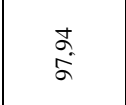 & $\frac{n}{\frac{n}{n}}$ & 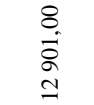 & $\begin{array}{l}n \\
\text { on } \\
m\end{array}$ & $\begin{array}{l}n \\
\text { â } \\
\hat{n}\end{array}$ & $\overrightarrow{\widehat{a}}$ & 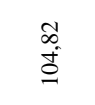 \\
\hline Transcarpathian & $\begin{array}{l}n \\
\text { ñ } \\
\text { ñ }\end{array}$ & \begin{tabular}{l}
$\stackrel{y}{2}$ \\
\multirow{i}{*}{}
\end{tabular} & 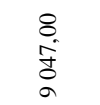 & $\begin{array}{l}8 \\
6 \\
\llcorner \\
0\end{array}$ & $\begin{array}{l}n \\
\tilde{N} \\
\infty\end{array}$ & 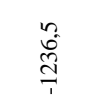 & $\begin{array}{l}\text { مे } \\
\text { ڤ̆ }\end{array}$ & $\begin{array}{l}\stackrel{2}{N} \\
\stackrel{m}{=}\end{array}$ \\
\hline Zaporizhia & 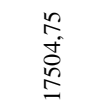 & $\frac{1}{2}$ & $\begin{array}{l}\stackrel{2}{1} \\
\frac{0}{0} \\
0\end{array}$ & $\begin{array}{l}8 \\
\dot{0} \\
0 \\
n\end{array}$ & $\begin{array}{l}n \\
m \\
m \\
m\end{array}$ & $\begin{array}{l}n \\
\stackrel{2}{8} \\
\stackrel{8}{+} \\
+\end{array}$ & $\begin{array}{c}\text { m. } \\
\text { â }\end{array}$ & సે \\
\hline
\end{tabular}


Continuation Table 3

\begin{tabular}{|c|c|c|c|c|c|c|c|c|}
\hline 1 & 2 & 3 & 4 & 5 & 6 & 7 & 8 & 9 \\
\hline $\begin{array}{l}\text { Ivano- } \\
\text { Frankivsk }\end{array}$ & $\begin{array}{l}8 \\
\therefore \\
\infty \\
\infty \\
\simeq\end{array}$ & $\stackrel{\infty}{\sigma^{\prime}}$ & 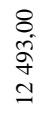 & $\begin{array}{l}8 \\
\text { i } \\
0 \\
\pm\end{array}$ & $\begin{array}{l}8 \\
\text { did }\end{array}$ & $\begin{array}{l}8 \\
8 \\
2 \\
7 \\
7\end{array}$ & $\stackrel{5}{5}$ & 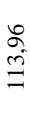 \\
\hline Kyiv & $\begin{array}{l}n \\
\infty \\
0 \\
0 \\
=\end{array}$ & $\begin{array}{l}\text { oे } \\
\text { i }\end{array}$ & 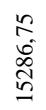 & 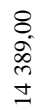 & 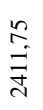 &  & $\begin{array}{c}\hat{m} \\
\text { - } \\
\infty\end{array}$ & $\frac{m}{\infty}$ \\
\hline Kirovohrad & $\underset{a}{\stackrel{n}{E}}$ & $\stackrel{\text { }}{\stackrel{0}{0}}$ & 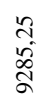 & $\begin{array}{l}8 \\
\stackrel{\leftrightarrow}{\Delta} \\
\text { a }\end{array}$ & $\begin{array}{l}\text { ñ } \\
\text { s. } \\
\text { oे }\end{array}$ & 吕 & $\begin{array}{l}\text { ô. } \\
\text { s. }\end{array}$ & $\begin{array}{l}\infty \\
\dot{\alpha}\end{array}$ \\
\hline Luhansk & $\begin{array}{l}n \\
n \\
\infty \\
\infty \\
i \\
i\end{array}$ & $\begin{array}{l}\hat{0} \\
\dot{m}\end{array}$ & 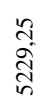 & $\begin{array}{l}8 \\
\stackrel{\infty}{\infty} \\
\frac{\infty}{n}\end{array}$ & $\begin{array}{l}\frac{8}{2} \\
\frac{\vec{m}}{\mathrm{~d}}\end{array}$ & 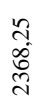 & $\begin{array}{l}\text { å } \\
\text { వై }\end{array}$ & $\begin{array}{l}0 \\
\text { o } \\
0\end{array}$ \\
\hline Lviv & 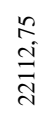 & $\begin{array}{l}\hat{\imath} \\
\stackrel{\infty}{\infty}\end{array}$ & $\begin{array}{l}n \\
\infty \\
\infty \\
\infty \\
\vec{\lambda}\end{array}$ & $\begin{array}{l}8 \\
\stackrel{1}{0} \\
\infty \\
\infty \\
+\end{array}$ & $\begin{array}{l}\text { ते } \\
\text { तิ }\end{array}$ & 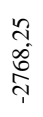 & $\begin{array}{l}\stackrel{0}{\infty} \\
\infty\end{array}$ & în \\
\hline Mykolaiv & $\frac{n}{\stackrel{n}{0}}$ & $\stackrel{1}{\infty}$ & $\begin{array}{l}\frac{n}{2} \\
\frac{j}{a}\end{array}$ & 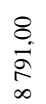 & $\begin{array}{l}8 \\
\text { in } \\
\text { in }\end{array}$ & $\begin{array}{l}n \\
0 \\
\infty \\
\infty\end{array}$ & \begin{tabular}{l}
$n$ \\
\multirow{2}{*}{}
\end{tabular} & हे \\
\hline Odesa & $\begin{array}{l}n \\
\text { ñ } \\
\stackrel{2}{n}\end{array}$ & $\infty$ & $\begin{array}{l}n \\
n \\
\infty \\
\infty \\
\infty\end{array}$ & $\begin{array}{l}8 \\
0 \\
0 \\
0 \\
\infty \\
-\infty\end{array}$ & $\begin{array}{l}8 \\
\text { d } \\
\text { d } \\
\text { N }\end{array}$ & $\begin{array}{l}n \\
\stackrel{n}{\vec{n}}\end{array}$ & $\begin{array}{l}\bar{\lambda} \\
\text { के }\end{array}$ & $\begin{array}{c}\text { oे } \\
\infty \\
\infty\end{array}$ \\
\hline Poltava & $\begin{array}{l}n \\
\hat{a} \\
\hat{\sigma} \\
\end{array}$ & $\hat{a}$ & $\begin{array}{l}\frac{n}{n} \\
\frac{n}{n}\end{array}$ & $\begin{array}{l}8 \\
i \\
\infty \\
m \\
m\end{array}$ & 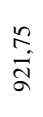 & \begin{tabular}{l} 
an \\
\multirow{2}{*}{}
\end{tabular} & ga & 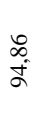 \\
\hline Rivne & 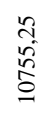 & $\begin{array}{l}\overrightarrow{\hat{j}} \\
\text { S }\end{array}$ & $\begin{array}{l}\text { n } \\
0 \\
0 \\
0 \\
0 \\
0\end{array}$ & $\begin{array}{l}8 \\
8 \\
00 \\
0 \\
0\end{array}$ & 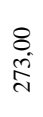 & $\begin{array}{l}n \\
\stackrel{2}{0} \\
\stackrel{1}{1}\end{array}$ & $\begin{array}{l}0 \\
\vdots \\
a \\
a\end{array}$ & : \\
\hline Sumy & 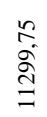 & ह̂. & 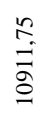 & $\begin{array}{l}8 \\
8 \\
0 \\
= \\
=\end{array}$ & $\begin{array}{l}8 \\
\substack{\infty \\
\infty \\
\infty}\end{array}$ & $\frac{n}{2}$ & $\begin{array}{l}n \\
\text { s. } \\
\sigma^{2}\end{array}$ & $\begin{array}{l}6 \\
8 \\
2\end{array}$ \\
\hline
\end{tabular}


Continuation Table 3

\begin{tabular}{|c|c|c|c|c|c|c|c|c|}
\hline 1 & 2 & 3 & 4 & 5 & 6 & 7 & 8 & 9 \\
\hline Ternopil & $\begin{array}{l}8 \\
\varnothing \\
\& \\
\& \\
0\end{array}$ & $\begin{array}{l}n \\
n \\
0\end{array}$ & $\begin{array}{l}\stackrel{n}{\circ} \\
\stackrel{2}{\circ} \\
\infty\end{array}$ & $\begin{array}{l}8 \\
\frac{8}{5} \\
=\end{array}$ &  & $\begin{array}{l}8 \\
8 \\
0 \\
0 \\
-1\end{array}$ & $\begin{array}{l}\text { ర్ } \\
\text { \&े }\end{array}$ & $\begin{array}{l}m \\
\stackrel{m}{=}\end{array}$ \\
\hline Kharkiv & $\begin{array}{l}\stackrel{n}{\approx} \\
\tilde{\sigma} \\
\tilde{n}\end{array}$ & $\begin{array}{l}\infty \\
n \\
n \\
\infty\end{array}$ & 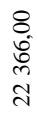 & 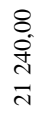 & $\begin{array}{l}\stackrel{n}{n} \\
\stackrel{2}{=}\end{array}$ & $\frac{n}{\stackrel{n}{i}}$ & $\frac{m}{n}$ & mे \\
\hline Kherson & $\frac{n}{\tilde{n}}$ & $\begin{array}{l}\hat{6} \\
\infty \\
\infty\end{array}$ & $\begin{array}{l}n \\
\stackrel{+}{S} \\
\stackrel{5}{2}\end{array}$ & $\begin{array}{l}8 \\
8 \\
\infty \\
\infty \\
\infty \\
\infty\end{array}$ & $\underset{\text { n }}{\stackrel{8}{8}}$ & $\begin{array}{l}n \\
\stackrel{n}{f}\end{array}$ & $\begin{array}{l}\text { o̊ } \\
\text { \&̊ }\end{array}$ & $\stackrel{2}{\approx}$ \\
\hline Khmelnitsky & $\begin{array}{l}\frac{n}{m} \\
=\end{array}$ & $\begin{array}{l}\text { f } \\
\stackrel{\infty}{\infty}\end{array}$ & $\begin{array}{l}8 \\
0 \\
0 \\
0 \\
= \\
=\end{array}$ & $\begin{array}{l}8 \\
0 \\
\hat{n} \\
\end{array}$ & $\begin{array}{l}n \\
\text { ñ } \\
\text { ne }\end{array}$ & $\begin{array}{l}n \\
\text { nू } \\
\text { ñ }\end{array}$ & $\stackrel{3}{5}$ & $\begin{array}{l}\hat{s} \\
\hat{s}\end{array}$ \\
\hline Cherkasy & 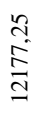 & 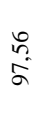 & $\begin{array}{l}8 \\
\text { లె } \\
\infty \\
=\end{array}$ & $\begin{array}{l}8 \\
0 \\
2 \\
\infty \\
=\end{array}$ & $\begin{array}{l}\stackrel{n}{y} \\
\underset{ \pm}{ \pm}\end{array}$ & $\begin{array}{l}2 \\
\text { Iี } \\
\text { In }\end{array}$ & \begin{tabular}{l} 
I \\
\multirow{5}{*}{}
\end{tabular} & $\stackrel{2}{2}$ \\
\hline Chernivtsi & $\begin{array}{l}\stackrel{n}{\circ} \\
\stackrel{\infty}{ \pm} \\
\stackrel{\infty}{\leftarrow}\end{array}$ & $\underset{\infty}{+}$ & \begin{tabular}{l}
$n$ \\
\multirow{2}{N}{} \\
Na
\end{tabular} & $\begin{array}{l}8 \\
\stackrel{8}{2} \\
\infty \\
\infty\end{array}$ & $\begin{array}{l}\text { aे } \\
\text { fे }\end{array}$ & $\begin{array}{l}n \\
n \\
\infty \\
\infty \\
0 \\
+1\end{array}$ & $\frac{2}{\infty}$ & $\begin{array}{l}\text { ô } \\
\stackrel{\Xi}{\beth}\end{array}$ \\
\hline Chernihiv & $\begin{array}{l}\stackrel{n}{0} \\
\stackrel{0}{0} \\
=\end{array}$ & $\begin{array}{l}\widehat{y} \\
\infty \\
0\end{array}$ & $\frac{\mathfrak{n}}{\mathfrak{n}}$ & $\begin{array}{l}8 \\
i n \\
a \\
0\end{array}$ & $\begin{array}{l}n \\
n \\
n \\
n\end{array}$ & $\begin{array}{l}\stackrel{n}{2} \\
\vec{i}\end{array}$ & $\begin{array}{l}\sigma \\
\alpha \\
\dot{\sigma}\end{array}$ & $\begin{array}{l}\text { స̂} \\
\text { ڤ̊ }\end{array}$ \\
\hline Kyiv city & 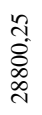 & $\begin{array}{l}= \\
\Xi\end{array}$ & $\frac{n}{2}$ & 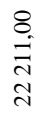 & 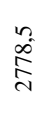 & $\begin{array}{l}2 \\
2 \\
\infty \\
\infty \\
\tilde{b}\end{array}$ & $\begin{array}{l}m \\
\stackrel{m}{2} \\
\overbrace{}^{2}\end{array}$ & $\frac{7}{\approx}$ \\
\hline
\end{tabular}


Table 4

Data on mid-level medical workers in terms of the regions of Ukraine, 2018

\begin{tabular}{|c|c|c|c|c|c|c|c|c|}
\hline Region & 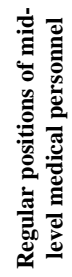 & 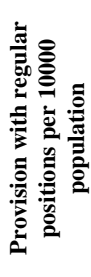 & 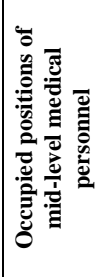 & 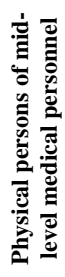 & 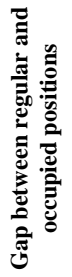 & 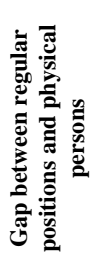 & 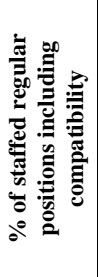 & 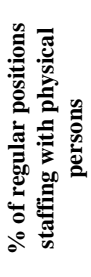 \\
\hline 1 & 2 & 3 & 4 & 5 & 6 & 7 & 8 & 9 \\
\hline Ukraine & 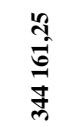 & $\begin{array}{l}\infty \\
\Rightarrow \\
\frac{\infty}{2}\end{array}$ & $\begin{array}{l}\text { in } \\
\text { in } \\
\stackrel{0}{0} \\
\text { co }\end{array}$ & $\begin{array}{l}\stackrel{\Xi}{ } \\
\text { ป̀ } \\
\frac{m}{m}\end{array}$ & 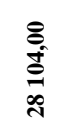 & $\begin{array}{l}\text { A2 } \\
\hat{2} \\
\hat{0}\end{array}$ & \begin{tabular}{l}
$\infty$ \\
\hdashline \\
\hdashline
\end{tabular} & $\begin{array}{l}5 \\
\sigma\end{array}$ \\
\hline Vinnitsia & $\begin{array}{l}n \\
\hat{8} \\
q \\
q \\
=\end{array}$ & $\begin{array}{l}\text { त̂ } \\
\text { ळी }\end{array}$ & $\begin{array}{l}8 \\
\dot{a} \\
\text { I } \\
\simeq\end{array}$ & $\begin{array}{l}8 \\
\overleftarrow{5} \\
0 \\
m \\
\end{array}$ & $\begin{array}{l}\stackrel{n}{2} \\
\stackrel{n}{n}\end{array}$ & 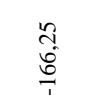 & 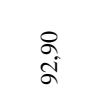 & 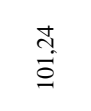 \\
\hline Volyn & 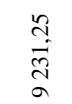 & $\begin{array}{l}q \\
\stackrel{+}{\infty}\end{array}$ & $\begin{array}{l}\stackrel{8}{0} \\
\text { त్ } \\
\infty\end{array}$ & $\begin{array}{l}8 \\
\text { in } \\
\stackrel{1}{5} \\
a\end{array}$ & $\begin{array}{l}\text { ñ } \\
\text { ț }\end{array}$ & 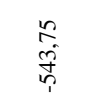 & ra & $\begin{array}{l}\text { oे } \\
\stackrel{0}{0} \\
0\end{array}$ \\
\hline Dnipropetrovsk & $\begin{array}{l}8 \\
\infty \\
\infty \\
\Delta \\
\Delta \\
\Delta\end{array}$ & $\begin{array}{c} \pm \\
\frac{m}{2} \\
\infty\end{array}$ & 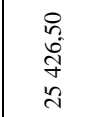 & \begin{tabular}{l}
8 \\
i \\
gे \\
\multirow{2}{7}{}
\end{tabular} & 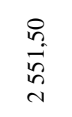 & $\begin{array}{l}8 \\
\text {. } \\
\text { in } \\
+\end{array}$ & $\begin{array}{l}\infty \\
\infty \\
\overbrace{}^{-1}\end{array}$ & $\begin{array}{l}\infty_{0} \\
\infty \\
\infty\end{array}$ \\
\hline Donetsk & 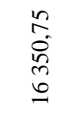 & 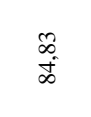 & $\begin{array}{l}n \\
\stackrel{n}{\infty} \\
\stackrel{\infty}{ \pm} \\
\pm\end{array}$ & $\begin{array}{l}8 \\
\stackrel{-}{0} \\
9 \\
=\end{array}$ & 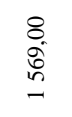 &  & $\begin{array}{l}q \\
\text { s. }\end{array}$ & 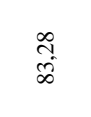 \\
\hline Zhytomyr & $\begin{array}{l}\text { वै } \\
\text { J } \\
\text { J }\end{array}$ & $\begin{array}{l}\vec{\beta} \\
\text { g. }\end{array}$ & $\begin{array}{l}0 \\
\text { ते } \\
\text { o } \\
0\end{array}$ & $\begin{array}{l}8 \\
\stackrel{j}{+} \\
\stackrel{m}{=} \\
=\end{array}$ & $\begin{array}{l}\stackrel{n}{\hat{n}} \\
\stackrel{n}{n}\end{array}$ & $\begin{array}{l}\text { ñ } \\
\alpha^{\infty}\end{array}$ & $\begin{array}{l}\text { f } \\
\text { s. }\end{array}$ & $\frac{ \pm}{\sigma}$ \\
\hline Transcarpathian & $\begin{array}{l}\stackrel{n}{\hat{b}} \\
\stackrel{6}{a} \\
a\end{array}$ & $\begin{array}{l}\stackrel{8}{i} \\
\text { in }\end{array}$ & $\begin{array}{l}8 \\
8 \\
\infty \\
\sigma \\
\infty\end{array}$ & $\begin{array}{l}8 \\
\text { in } \\
\text { a }\end{array}$ & 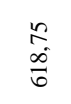 & $\begin{array}{l}\text { aे } \\
\text { ô } \\
\text { ô }\end{array}$ & $\overrightarrow{\widetilde{\sigma}}$ & $\begin{array}{l}\text { fo } \\
\text { fo }\end{array}$ \\
\hline Zaporizhia & 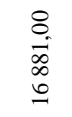 & $\begin{array}{l}\overrightarrow{0} \\
\sigma^{\prime}\end{array}$ & 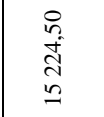 & $\begin{array}{l}8 \\
0 \\
0 \\
0 \\
0\end{array}$ & $\begin{array}{l}0 \\
\text { n. } \\
\text { है } \\
\text { d. }\end{array}$ & $\begin{array}{l}\stackrel{8}{0} \\
\text { i } \\
0 \\
m\end{array}$ & $\frac{2}{8}$ & $\begin{array}{l}0 \\
\underset{\infty}{*}\end{array}$ \\
\hline
\end{tabular}


Continuation Table 4

\begin{tabular}{|c|c|c|c|c|c|c|c|c|}
\hline 1 & 2 & 3 & 4 & 5 & 6 & 7 & 8 & 9 \\
\hline Ivano-Frankivsk & $\begin{array}{l}\stackrel{n}{2} \\
\stackrel{2}{0} \\
\stackrel{m}{\simeq}\end{array}$ & $\begin{array}{l}\stackrel{1}{ } \\
\stackrel{8}{8}\end{array}$ & $\begin{array}{l}8 \\
i \\
2 \\
=\end{array}$ & 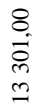 & $\frac{n}{2}$ & 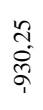 & $\frac{0}{2}$ & $\begin{array}{l}\sqrt{n} \\
\stackrel{0}{0}\end{array}$ \\
\hline Kyiv & 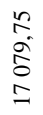 & $\begin{array}{l}\text { مू } \\
\text { ò }\end{array}$ & $\begin{array}{l}\dot{p} \\
m \\
\infty \\
m \\
\dot{D}\end{array}$ & 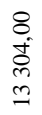 & $\begin{array}{l}\text { a } \\
\text { ó } \\
\text { bे } \\
\text { v }\end{array}$ & $\frac{n}{2}$ & $\begin{array}{l}\overrightarrow{+} \\
\vec{\infty}\end{array}$ & $\begin{array}{l}\text { के } \\
\stackrel{1}{N}\end{array}$ \\
\hline Kirovohrad & 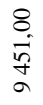 & $\begin{array}{l}\text { ț } \\
8 \\
8\end{array}$ & \begin{tabular}{l}
$n$ \\
\multirow{\delta}{0}{} \\
$\infty$ \\
$\infty$
\end{tabular} &  & $\begin{array}{l}\text { a } \\
\dot{f} \\
\text { in }\end{array}$ & $\begin{array}{l}8 \\
\text { dீं }\end{array}$ & $\begin{array}{l} \pm \\
\dot{A}\end{array}$ & $\begin{array}{l}\infty \\
\infty \\
\infty\end{array}$ \\
\hline Luhansk & $\begin{array}{l}\frac{n}{2} \\
\stackrel{2}{2} \\
0\end{array}$ & $\begin{array}{l}\stackrel{2}{1} \\
\infty \\
\infty\end{array}$ & $\begin{array}{l}8 \\
\infty \\
\infty \\
\text { in } \\
\text { in }\end{array}$ & $\begin{array}{l}8 \\
\frac{8}{n} \\
\text { in }\end{array}$ & $\begin{array}{l}n \\
\frac{n}{0} \\
6\end{array}$ & $\frac{n}{2}$ & $\begin{array}{l}\stackrel{2}{2} \\
\stackrel{2}{\infty}\end{array}$ & $\begin{array}{l}n \\
\infty \\
\infty\end{array}$ \\
\hline Lviv & $\begin{array}{l}n \\
\infty \\
\infty \\
\stackrel{+}{+} \\
\vec{N}\end{array}$ & $\underset{\infty}{\infty}$ & 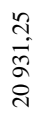 & $\begin{array}{l}8 \\
\text { an } \\
\text { तn } \\
\text { त̃ }\end{array}$ & $\begin{array}{l}\text { in } \\
\text { तn } \\
\text { n. }\end{array}$ & 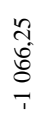 &  & $\begin{array}{l}\hat{\sigma} \\
\text { d }\end{array}$ \\
\hline Mykolaiv & 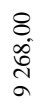 & $\frac{a}{\infty}$ & $\begin{array}{l}\infty \\
\substack{\infty \\
\infty \\
\infty}\end{array}$ & $\underset{i}{\stackrel{8}{i}}$ & $\begin{array}{l}0 \\
\infty \\
\infty \\
\infty \\
\infty\end{array}$ & $\begin{array}{l}8 \\
\stackrel{8}{+} \\
\stackrel{a}{-}\end{array}$ & $\stackrel{f}{\stackrel{8}{8}}$ & $\begin{array}{l}\infty \\
\infty \\
\infty\end{array}$ \\
\hline Odesa &  & $\begin{array}{l}\vec{\sigma} \\
\infty_{\infty}\end{array}$ & $\begin{array}{l}n \\
\text { an } \\
\text { vi } \\
\text { I }\end{array}$ & $\begin{array}{l}8 \\
\underset{m}{n} \\
0 \\
0\end{array}$ & $\begin{array}{l}8 \\
0 \\
0 \\
0 \\
1\end{array}$ & $\begin{array}{l}n \\
n \\
m \\
m \\
m\end{array}$ & $\begin{array}{l}R \\
\infty \\
\infty\end{array}$ & $\begin{array}{l}\& \\
+ \\
\infty\end{array}$ \\
\hline Poltava & 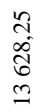 & 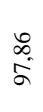 & 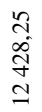 & $\begin{array}{l}8 \\
+ \\
\text { N } \\
\text { I }\end{array}$ & $\begin{array}{l}8 \\
\stackrel{8}{8} \\
\stackrel{-}{8}\end{array}$ & \begin{tabular}{l}
$\tilde{a}$ \\
\multirow{J}{*}{} \\
-
\end{tabular} & $\frac{a}{a}$ & $\frac{ \pm}{8}$ \\
\hline Rivne & $\begin{array}{l}8 \\
-1 \\
\text { f } \\
0\end{array}$ & $\begin{array}{l}\text { ô } \\
\text { a }\end{array}$ & $\begin{array}{l}n \\
\stackrel{n}{-} \\
\stackrel{N}{0} \\
0\end{array}$ & $\begin{array}{l}8 \\
8 \\
\dot{+} \\
=\end{array}$ & $\begin{array}{l}\tilde{2} \\
\hat{\jmath} \\
\dot{\gamma}\end{array}$ & $\begin{array}{l}8 \\
8 \\
0 \\
0 \\
1\end{array}$ & $\begin{array}{l}\infty \\
\infty \\
a\end{array}$ & 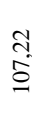 \\
\hline Sumy & 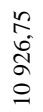 & 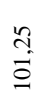 & $\begin{array}{l}8 \\
\stackrel{8}{8} \\
\text { m } \\
0\end{array}$ & $\begin{array}{l}8 \\
\infty \\
\stackrel{+}{+} \\
\stackrel{0}{0}\end{array}$ & $\begin{array}{l}n \\
\hat{\sigma} \\
n \\
n\end{array}$ & $\begin{array}{l}\stackrel{n}{2} \\
\infty \\
o \\
\sigma\end{array}$ & $\begin{array}{l}\stackrel{2}{\circ} \\
\dot{\sigma}\end{array}$ & \begin{tabular}{l}
7 \\
\multirow{2}{\alpha}{}
\end{tabular} \\
\hline Ternopil & $\begin{array}{l}\text { à } \\
\text { à } \\
\text { à }\end{array}$ & $\begin{array}{l}8 \\
\text { a }\end{array}$ & 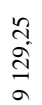 & $\begin{array}{l}8 \\
1 \\
5 \\
0 \\
0\end{array}$ & $\begin{array}{l}8 \\
0 \\
0 \\
0\end{array}$ & $\begin{array}{l}\frac{n}{n} \\
\frac{n}{n}\end{array}$ & $\begin{array}{l}\text { in } \\
\text { nू }\end{array}$ & $\begin{array}{l} \pm \\
\text { है }\end{array}$ \\
\hline
\end{tabular}


Continuation Table 4

\begin{tabular}{|c|c|c|c|c|c|c|c|c|}
\hline 1 & 2 & 3 & 4 & 5 & 6 & 7 & 8 & 9 \\
\hline Kharkiv & 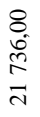 & $\underset{\infty}{\stackrel{N}{+}}$ & 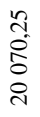 & $\begin{array}{l}8 \\
\text { on } \\
\text { on } \\
0\end{array}$ & $\begin{array}{l}2 \\
2 \\
0 \\
0\end{array}$ & $\begin{array}{l}\frac{8}{\dot{J}} \\
\underset{m}{\vec{j}}\end{array}$ & 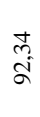 & $\begin{array}{l}n \\
n \\
n \\
\infty\end{array}$ \\
\hline Kherson &  & $\begin{array}{l}8 \\
\frac{8}{\infty}\end{array}$ & $\begin{array}{l}n \\
n \\
\infty \\
\infty \\
\infty \\
\infty\end{array}$ & $\begin{array}{l}8 \\
\text { S. } \\
\text { S- }\end{array}$ & $\begin{array}{l}\text { ते } \\
\text { s. } \\
\text { n. }\end{array}$ & 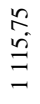 & 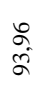 & $\begin{array}{l}n \\
\stackrel{n}{\infty} \\
\infty\end{array}$ \\
\hline Khmelnitsky & $\begin{array}{l}8 \\
\text { o. } \\
= \\
=\end{array}$ & $\begin{array}{l}\stackrel{\Omega}{\tilde{\infty}} \\
\frac{1}{2}\end{array}$ & $\begin{array}{l}\text { r } \\
\text { s. } \\
\vdots \\
0\end{array}$ & 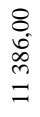 & $\begin{array}{l}n \\
n \\
n\end{array}$ & $\begin{array}{l}8 \\
\text { } \\
\text { ते }\end{array}$ & $\begin{array}{l}n \\
m \\
s\end{array}$ & $\begin{array}{l}\text { ț } \\
\text { di }\end{array}$ \\
\hline Cherkasy & 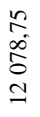 & $\begin{array}{l}\text { qu } \\
8 \\
8\end{array}$ & 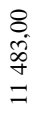 & $\begin{array}{l}8 \\
+ \\
\infty \\
\infty \\
\varrho\end{array}$ & $\begin{array}{l}n \\
\text { s. } \\
\text { on }\end{array}$ & $\begin{array}{l}\text { 足 } \\
+\underset{d}{+}\end{array}$ & $\begin{array}{l}5 \\
\dot{a} \\
\text { a }\end{array}$ & $\begin{array}{l}\hat{2} \\
\infty \\
\infty\end{array}$ \\
\hline Chernivtsi & \begin{tabular}{l}
$n$ \\
\multirow{f}{c}{} \\
d \\
$r$
\end{tabular} & $\stackrel{\overrightarrow{0}}{\vec{\infty}}$ & 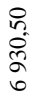 & $\begin{array}{l}8 \\
\infty \\
\infty \\
\infty \\
\infty\end{array}$ & $\begin{array}{l}\text { ? } \\
\text { f } \\
\text { f }\end{array}$ & $\begin{array}{l}\text { तે } \\
\text { o } \\
0 \\
1\end{array}$ & $\begin{array}{l}\text { ते } \\
\text { घे }\end{array}$ & $\begin{array}{l}= \\
\equiv\end{array}$ \\
\hline Chernihiv & $\begin{array}{l}8 \\
8 \\
0 \\
+1 \\
0\end{array}$ & 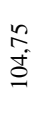 & $\begin{array}{l}\text { ra } \\
\text { f } \\
\infty \\
\sigma\end{array}$ & $\begin{array}{l}8 \\
8 \\
\infty \\
0 \\
0\end{array}$ & $\begin{array}{l}\stackrel{2}{a} \\
\overline{0}\end{array}$ & $\begin{array}{l}8 \\
\text { i. } \\
n \\
n\end{array}$ & $\begin{array}{l}\mathbb{I} \\
\text { J }\end{array}$ & $\begin{array}{c}\text { ले } \\
\text { से }\end{array}$ \\
\hline Kyiv city & $\begin{array}{l}2 \\
\hat{\sigma} \\
\vec{b} \\
\vdots\end{array}$ & $\begin{array}{l}\tilde{z} \\
\dot{\alpha}\end{array}$ & $\begin{array}{l}n \\
\text { ñ } \\
\text { co } \\
\text { ते }\end{array}$ & $\begin{array}{l}8 \\
\text { i } \\
\text { ते } \\
\text { in }\end{array}$ & $\begin{array}{l}8 \\
+ \\
\text { d. } \\
\text { m. }\end{array}$ & $\begin{array}{l}\stackrel{n}{r} \\
\text { ñ } \\
\stackrel{n}{r}\end{array}$ & $\begin{array}{l}4 \\
\infty \\
\infty\end{array}$ & 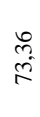 \\
\hline
\end{tabular}

In total, 315057 positions of secondary health workers are occupied with 313412.00 physical persons.

The level of staffing of the regular positions of medical workers taking into account the compatibility reached $91.83 \%$, and $91.07 \%$ by physical persons. The lowest level of staffing of the regular positions by individuals is registered in Kyiv (73.36\%) and Kyiv (77.89\%) region.

In the following regions of Ukraine definite part of mid-level medical workers are not employed full time: Vinnytsia, Volyn, Transcarpathian, Ivano-Frankivsk, Lviv, Rivne, Ternopil, Khmelnytsky, Chernivtsi.

In 2018 the shortage of secondary health workers in health care system of Ukraine amounted to 30749 individuals (14131 in 2014). The highest shortage of secondary medical personnel was registered in health care institutions of Kyiv (7 357), Dnipropetrovsk (4 526), Kyiv (3 775), Odesa (3 135), Kharkiv (3 141) and Zaporizhia (3 012) regions. 
Next the issue on mid-level medical personnel working in rural areas was studied. The obtained data are shown in Table 5.

13295 doctor's assistant and obstetrical centers functioned in Ukraine in 2018 for providing the rural population with pre-medical medical care. 537 doctor's assistant and obstetrical centers of their total number are not staffed with any medical professional. The largest number of not staffed doctor's assistant and obstetrical centers is registered in Chernihiv (73), Poltava (59), Dnipropetrovsk (50) and Sumy (44) regions.

All doctor's assistant and obstetrical centers in Ivano-Frankivsk and Chernivtsi regions are staffed with medical personnel.

Table 5

Data on mid-level medical personnel working in rural areas in terms of the regions of Ukraine, 2018

\begin{tabular}{|c|c|c|c|}
\hline Region & $\begin{array}{c}\text { Number of doctor's } \\
\text { assistant and } \\
\text { obstetrical center }\end{array}$ & $\begin{array}{l}\text { Number of doctor's } \\
\text { assistant and obstetrical } \\
\text { centers without mid- } \\
\text { level medical personnel }\end{array}$ & $\begin{array}{c}\text { Number of } \\
\text { mid-level } \\
\text { medical } \\
\text { personnel in } \\
\text { rural areas }\end{array}$ \\
\hline Ukraine & 13295,00 & 537,00 & 43273,00 \\
\hline Vinnitsia & 881,00 & 24,00 & 2817,00 \\
\hline Volyn & 764,00 & 22,00 & 1873,00 \\
\hline Dnipropetrovsk & 402,00 & 50,00 & 1878,00 \\
\hline Donetsk & 327,00 & 35,00 & 479,00 \\
\hline Zhitomir & 816,00 & 11,00 & 2332,00 \\
\hline Transcarpathian & 280,00 & 9,00 & 2763,00 \\
\hline Zaporizhia & 359,00 & 13,00 & 1100,00 \\
\hline Ivano-Frankivsk & 531,00 & - & 2040,00 \\
\hline Kyiv & 643,00 & 7,00 & 1852,00 \\
\hline Kirovohrad & 483,00 & 15,00 & 1288,00 \\
\hline Luhansk & 231,00 & 19,00 & 536,00 \\
\hline Lviv & 1004,00 & 1,00 & 3064,00 \\
\hline Mykolaiv & 385,00 & 33,00 & 1141,00 \\
\hline Odesa & 505,00 & 29,00 & 2204,00 \\
\hline Poltava & 624,00 & 59,00 & 1805,00 \\
\hline Rivne & 623,00 & 4,00 & 1849,00 \\
\hline Sumy & 519,00 & 44,00 & 1465,00 \\
\hline Ternopil & 733,00 & 7,00 & 2044,00 \\
\hline Kharkiv & 499,00 & 40,00 & 1767,00 \\
\hline Kherson & 348,00 & 9,00 & 1248,00 \\
\hline Khmelnitsky & 909,00 & 23,00 & 2933,00 \\
\hline Cherkasy & 540,00 & 10,00 & 2179,00 \\
\hline Chernivtsi & 212,00 & - & 1403,00 \\
\hline Chernihiv & 677,00 & 73,00 & 1213,00 \\
\hline
\end{tabular}


43273.00 mid-level medical workers were employed in rural areas in 2018. The largest number of mid-level medical professionals worked in rural areas in the following regions: Lviv (3064.00), Khmelnytsky (2933.00), Vinniytsia (2817.00), Transcarpathian (2763.00). The smallest number of mid-level medical professionals worked in rural areas in the following regions: Donetsk (479.00) and Lugansk (536.00).

It was determined in the course of study hat the ratio of the number of nurses and doctors in Ukraine tends to decrease with the index 1:2.0. In the countries of the European Union the ratio of doctors and nurses composes 1:4.1.

The number of mid-level medical personnel decreased by 17032 persons for the period 2017-2018. It is more than twice as much as in the previous year. At the same time, the number of obstetricians decreased by $8.4 \%$, the number of doctors' assistants decreased by $5.4 \%$, and nurses - by $4.3 \%$.

It was found in the course of the study that the share of medical nurses, who work at the primary medical care level, grows in the structure of secondary medical personnel. In 2014-2018 staffing with nurses increased almost by 1.5 times (from 4.7 to 6.5 per10 thousand population). This influenced the ratio of the number of nurses and physicians in health care institutions of primary level: in 2014 one family doctor accounted for 1.2 nurses, and in $2018-1.4$ nurses.

In 2018 the share of retirement age persons among mid-level medical personnel amounted to $13 \%$. The highest proportion of retirement age persons among mid-level medical personnel are observed in Kyiv, Cherkasy, Kirovohrad, Mykolayiv, Kherson, Dnipropetrovsk, and Donetsk regions. At the same time, in 2015-2018 the share of abiturients in the specialty "Nursing" of the level of junior specialist, which includes programs for training nurses, doctors' assistants and midwives, has been decreasing every year: from 3.70 to 2.64 per 10 thousand population. In 2018 the one abiturient in specialty "Nursing" accounted for 3.6 working pensioners among the mid-level medical personnel.

\section{CONCLUSIONS}

The article is focused on basic problems of personnel provision in health care system of Ukraine. The dynamics for 2014-2018 years of population provision in terms of the regions of Ukraine with physicians and mid-level medical workers are presented. Provision of rural population with physicians and mid-level medical workers is specially presented. The deficiency of physicians and mid-level medical personnel is shown in terms of regions. The author shows that the largest outflow of medical personnel from health 
care system of Ukraine was registered for the years 2017-2018. Taking into consideration that the personnel potential is the most significant component of the resource provision of health care system, the national health care system faces the task of optimizing human policies in health care system of the country.

\section{SUMMARY}

The undertaken analysis of personnel resources in health care system of Ukraine shows that in 2018 there were registered 191905.25 of regular positions of doctors with the level of provision 45.71 per 10 thousand population. In comparison to 2014 the number of regular positions decreased by 3015.25 , the level of their availability by 0.12 per 10 thousand people. In terms of regions, the differences in the level of provision with regular doctors' positions by 1.87 times were denoted: from 36.47 in Transcarpathian region to 68.09 in Kyiv. The gap between the regular posts and individuals of doctors in 2018 reached 35042.25 (34951.5 in 2014).

The level of regular positions staffing, taking into account the compatibility, reached $87.68 \%$, and the level of staffing by individuals amounted to $81.74 \%$ (82.07\% in 2014). 11398.25 of physicians' posts were occupied on the conditions of compatibility in 2018 (14 262.00 in 2014). The index of compatibility in health care system of Ukraine in 2018 amounted to 1.07 .

It was found in the course of study that in 2018 two-thirds of regular doctors' positions $(65.5 \%)$ belonged to hospitals and only one third (34.5\%) - to outpatient health care institutions. In EU countries 57\% of the doctors' positions were registered in hospitals. For the period 2017-2018 the number of doctors in health care system of Ukraine decreased by 2737 people, in 2018 in rural areas $5 \%$ of doctors worked.

344161.25 positions of secondary medical workers were introduced in health care system of Ukraine in 2018. Level of provision of these posts amounted to 81.98 per 10 thousand population (84.27 in 2014). The difference of the index noted in terms of the regions of the country composed 1.44 times.

In total, there are 316057 occupied positions of secondary health workers with 313412.00 physical persons. The shortage of secondary health workers in health care system of Ukraine in 2018 amounted to 30749 individuals (14131 in 2014). It was determined in the course of study that the ratio of the number of nurses and physicians in Ukraine tends to decrease with the index 1:2.0. 
The geographical distribution in the provision of physicians and nurses is uneven. The low availability of both physicians and nurses is registered in Transcarpathian, Kiev, Mykolaiv, Kherson, Donetsk and Luhansk regions.

It should be noted that in statistical statements used to plan personnel policies and human resources management, only a minimal set of indicators is used of the total number gathered by medical institutions. There are no aspects of staff turnover, their retention and satisfaction, efficiency and lifelong learning. Disaggregation is limited by gender and age, as well as in terms of urban/rural areas. There is no unified electronic register of medical personnel. National statistical reports on medical personnel are not harmonized with international standards. All that complicates the comparison of Ukrainian data as for human resources of health care system with other countries.

\section{REFERENCES}

1. Junious D.L. et al. (2004) A study of school nurse job satisfaction. Journal of School Nursing, no. 20, pp. 88-93.

2. Sovmestnaya rabota na blago zdorov'ya. Doklad o sostoyanii zdravookhraneniya v mire (2006) [Work together for Health. World Health Report]. Retrieved from: https://www.who.int/topics/health_workforce/ru/

3. Razvitie medicinskih kadrov [Medical personnel development]. WHO: website. Retrieved from: http://whodc.mednet.ru/ru/component/attachments/ download/20.html (accessed 13 November 2019).

4. Gupta N. et al. (2003) Uses of population census data for monitoring geographical imbalance in the health workforce: snapshots from three developing countries. International Journal for Equity in Health, no. 2, p. 11.

5. Maier, C. B., \& Aiken, L. H. (2016) Task shifting from physicians to nurses in primary care in 39 countries: a cross-country comparative study. European Journal of Public Health, no. 26 (6), pp. 927-934.

6. Boerma W.G.W., Kringos D.S., Wiegers T.A., Baltag V., \& Khimion, L. (2010) Evaluation of structure and provision of primary care in Ukraine: a survey-based project in the regions of Kiev and Vinnitsa.

7. Ghalijenko L. I. (2011) Suchasni kadrovi problemy okhorony zdorov'ja $v$ krajinakh Jevropejsjkogho reghionu [Modern problems of health care personnel in the countries of European Region] WHO. Skhidnojevropejsjkyj zhurnal ghromadsjkogho zdorov'ja, no. 1 (13), pp. 279-281.

8. Kadry zdravoohraneniya 2030. Globalnaya strategiya dlya razvitiya kadrovyh resursov zdravoohraneniya [Health personnel 2030. Global strategy for health workforce development] WHO website. Retrieved from: 
https://www.who.int/hrh/resources/russian_global_strategyHRH.pdf (accessed 12 November 2019).

9. Forcier MB et al. (2004). Impact, regulation and health policy implications of physician migration in OECD countries. Human Resources for Health, 2:12.

10. Diallo K. Data on the migration of health-care workers: sources, uses, and challenges (2004) Bulletin of the World Health Organization, no. 82, pp. 559-636.

11. Commonwealth Code of Practice for the International Recruitment of Health Workers (2003) London, Commonwealth Secretariat. Retrieved from: http://www.thecommonwealth.org/shared_asp_files/uploadedfiles/ \{7BDD970B-53AE-441D-81DB-1B64C37E992A\}_CommonwealthCodeof Practice.pdf, (accessed 15 April 2008).

12. Rasshirenie dostupa $\mathrm{k}$ rabotnikam zdravoohraneniya $\mathrm{v}$ otdalennyh $\mathrm{i}$ selskih rajonah. Rekomendacii po globalnoj politike. [Increased access to health workers in remote and rural areas. Global policy recommendations]. WHO website. Retrieved from: http://www.who.int/entity/hrh/retention/ retention_recommendations_ru.pdf (accessed 11 November 2019).

13. Ocenka finansirovaniya, obrazovaniya, upravleniya i politicheskogo konteksta dlya strategicheskogo planirovaniya kadrovyh resursov zdravoohraneniya [Assessment of financing, education, governance and policy context for strategic health workforce planning]. WHO website. Retrieved from: http://apps.who.int/gb/ebwha/pdf_files/WHA59REC1/r/Part2-Res-ru.pdf) (accessed 14 November 2019).

14. Lekhan V.M., Krjachkova L.V. (2017) Naukove obgruntuvannja suchasnykh pidkhodiv do pidghotovky kerivnykh medychnykh kadriv [Scientific substantiation of modern approaches to training of medical officials and executives] Proceedings of the Kadrova polityka u sferi okhorony zdorov'ja $\mathrm{v}$ umovakh zaghroz nacionaljnij bezpeci Ukrajiny (Ukraine, Kiev, March 23, 2017), Kiev, pp. 86-9.

15. Slabkyj Gh.O. (2018) Kadrova polityka [Personnel policy] Retrieved from: http://www.uiph.kiev.ua/index.asp?p=information $\& s=2$ (accessed 14 November 2019).

16. Vezhnovecj T.A. (2014) Do pytannja vyznachennja kryterijiv profesijnogho psykhologhichnogho doboru kerivnykiv zakladiv okhorony zdorov'ja [Issues on determination of the criteria for professional psychological choice of health care managers] Ukrajinsjkyj zhurnal $z$ problem medycyny praci, no 1, pp. 28-36.

17. Voronenko V., Feshhenko I. (2011) [Personnel is a key to success] Vashe zdorov'ja, no 49. Retrieved from: http:// www.vz.kiev.ua/?p=3813. 
18. Vasjuk N.O. (2015) Udoskonalennja kadrovogho zabezpechennja derzhavnogho upravlinnja okhoronoju zdorov ja v Ukrajini [Improvement of staffing of state health care management in Ukraine] Zbirnyk naukovykh pracj Nacionaljnoji akademiji derzhavnogho upravlinnja pry Prezydentovi Ukrajiny Vol. 2, pp. 34-51.

19. Nacionaljna strateghija reformuvannja systemy okhorony zdorov'ja $v$ Ukrajini na period 2015-2020 rokiv [National Health Care Reform Strategy in Ukraine for 2015-2020] Retrieved from: https://moz.gov.ua/ uploads/0/691-strategiya.pdf.

20. Pro skhvalennja Koncepciji reformy finansuvannja systemy okhorony zdorov'ja, Rozporjadzhennja Kabinetu Ministriv Ukrajiny №1013-r vid 30.11.2016 [On the approval of the Concept of Healthcare Financing Reform, Order of the Cabinet of Ministers of Ukraine № 1013-p of 30.11.2016] Retrieved from: https://zakon.rada.gov.ua/laws/show/10132016-p.

21. Derzhavnyj zaklad «Centr medychnoji statystyky Ministerstva okhorony zdorov'ja Ukrajiny [State Institution «Center for Medical Statistics of the Ministry of Health of Ukraine»]. Retrieved from: http://medstat.gov.ua.

22. Boghdan D., Bojko A., Vasyljkova A. ta in. (2019) Kadrovi resursy systemy okhorony zdorov'ja v Ukrajini. Sytuacijnyj analiz [Human resources of the health care system in Ukraine. Situational analysis] Proekt USAID «Pidtrymka reformy okhorony zdorov’ja» Kyjiv, 133 p.

\section{Information about the author:} Slabkiy G. O., orcid.org/0000-0003-2308-7869 Professor at the Department of Health Sciences

Uzhhorod National University 29, Mytna str., 88000, Uzhhorod, Ukraine 
DOI https://doi.org/10.36059/978-966-397-155-1/26-43

\title{
TRAINING OF PUBLIC HEALTH PROFESSIONALS IN UKRAINE: EXPERIENCE AND PROBLEMS
}

\author{
Bilak-Lukianchuk V. Yo.
}

\section{INTRODUCTION}

Health of the population is the most important resource in any country. In nowadays reality, all national health systems are prioritizing and developing public health services. One of the main tasks of reforming the health care system, implementing and improving public health services is to prepare a new generation of public health professionals. Formation of Ukraine as a democratic, legal, social state with a socially-oriented economy, its European and Euro-Atlantic integration envisage creation and development of a highly-qualified structure of health care professionals both in medical institutions and in governmental agencies - practitioners and scientists, civil servants and local government officials.

Human resources ensure the efficiency and quality of the provision of appropriate medical and management services. Human resources is working capacity of the company, the ability of staff to generate ideas, create new products, its educational, qualification level, psychophysiological characteristics and motivation.

Stability of system potential and human resources development are among the priorities of new European policy «Health 2020». All 53 Member States of European region of WHO have decided to create a new common policy framework - «Health 2020». Its general goal is «to significantly improve health and promote well-being of the population, reduce health inequalities, strengthen public health system and ensure that there are universal, socially just, sustainable and high-quality humancentered health care systems». «Health 2020» takes into account the diversity of countries in the region. Policy framework appeals to diverse audiences - both within and outside governmental agencies - inspiring them and offering optimal ways to address complex health care challenges in the 21 st century. Health care efficiency and economic efficiency are interrelated.

1 Zdorov'e - 2020. Osnovy evropeyskoy politiki i strategiya dlya XXI veka (2013) [Health -2020 . European policy framework and strategy for the 21 st century]. Retrieved from: http://www.euro. who.int/PubRequest?language=Russian 
At the same time, the optimal use of resources in health care sector and, above all, human resources is crucial.

In Ukraine, the health care area is focused on treating diseases rather than preventing them. Most resources are directed at treatment of diseases, and only a small portion are concentrated on preserving health. One of the key tasks of health care reform is to shift from a treatment policy to a policy of preserving and promoting health and preventing diseases.

Public health is a system of scientific, political, economic, medical and social measures aimed at organizing the efforts of society, state-owned and non-governmental institutions, communities and individuals to promote health, prevent diseases, extent active and working age by providing conditions that keep people healthy, as well as promoting a healthy lifestyle. Public health is concerned with threats to health of the population. Public health focuses on improving health and quality of life through the prevention and recovery from diseases and the elimination of factors that affect physical and mental health, by controlling the determinants of health and shaping a healthy lifestyle. Modern public health practice requires the effective work of an interdisciplinary team of specialists.

The aim is to create a system in which each central and local government executive takes into account consequences of his/her decisions for health of the population and prioritizes activities that help people avoid illness and injury and be healthy. Building a public health system in Ukraine is one of the requirements of the Association Agreement between Ukraine and the European Union.

In the European Region of WHO, the definition of public health as «the science and practice of disease prevention, life extension and health promotion through organized, community-based action» proposed by Acheson is used ${ }^{2}$.

\section{International and national prerequisites for training personnel for public health system}

In 2012, the European Regional Bureau of the World Health Organization (WHO) adopted the document «European Action Plan for Strengthening of Public Health Capacities and Services» (EAP), which has become a guide to public health development in European region ${ }^{3}$.

\footnotetext{
${ }^{2}$ Acheson D. (1988) Public health in England: the report of the Committee of Inquiry into the Future Development of the Public Health Function. London, H. M. Stationery Office.

3 Evropeyskiy plan deystviy po ukrepleniyu potentsiala i uslug obshchestvennogo zdravookhraneniya (2012) [European Action Plan for Strengthening of Public Health Capacities and Services]. Copenhagen: WHO Regional Office for Europe, (document EUR/RC62/12).
} 
The objective of the EAP is to support European Member States in improving health, reducing inequality, and ensuring implementation of essential public health operations (EPHOs) and a basic list of affordable, high quality, effective public health services on an individual basis, local and population levels, and strengthening the capacity of the public health system.

The task of EAP is to develop and implement, monitor, evaluate actions on strengthening of public health system potential and services through a broad consultation process involving all WHO Member States and key international partners.

The EAP on strengthening of public health system potential and services across Europe is not just a technical document. It is an action-oriented initiative, and its development and implementation reflects the values and principles secured at «Health 2020», outlining the vision and direction of health policy for sake of health in Europe in the 21st century.

Resolution of WHO Regional Committee for Europe EUR/RC60/R5 outlines major areas of action to address key public health care and health policy challenges in Europe that need to increase political commitment to the development of public health capacities, functions and services, and take concrete steps to invest resources in preventing and promoting human health; to continue actively focus on health systems strengthening (conform and, where appropriate, clarify definitions, concepts, functions and relationships, and develop tools for practical implementation), to review public health care tools for the 21 st century; to conduct critical appraisal of all ongoing activities, especially in setting standards and norms, in order to make best use of the experience and structures existing in the Region; to work closely with partners when solving all of the above tasks.

Both principles of «Health 2020» and EAP call for a commitment to improving health and reducing inequalities through a nationwide and community-wide approach. That is, the task of improving public health involves appropriate mechanisms of strategic management, and the decisionmaking process is based on basic principles of human rights, social justice, partnerships and sustainable development ${ }^{4}$.

The EAP is one of the fundamental components of the policy «Health 2020». Key areas of activity regard to strengthening and further development and supporting potential and services of public health system to

\footnotetext{
${ }^{4}$ Slabkyj Gh.O., Myronjuk I.S., Kachala L.O. (2017) Systema ghromadsjkogho zdorov’ja: bachennja Vsesvitnjoji orghanizaciji okhorony zdorov'ja, Osnovni operatyvni funkciji ghromadsjkogho zdorov'ja ta jikh zmist [Public Health System: World Health Organization Vision, Essential Public Health Functions and Their Meaning]. Ukrajina. Zdorov'ja naciji, no. 3 (44), pp. 24-31.
} 
improve health and reduce inequalities by influencing the social determinants of health. The unifying principle of the public health system is its social character, as well as the fact that it is focused mainly on the health of population in general. The public health system can be seen as a key aspect of the wider health care system and can play an important role in enhancing the efficiency and effectiveness of the functioning of health care system. It is proposed to keep the definition of «health care system» approved in 2008 by Tallinn Charter: «Within the political and institutional boundaries of each country, the health care system is the totality of all public and private organizations, institutions, resource structures which purpose is to improve, preserve or restore the health of people. Health care systems include the provision of both individual and public services, as well as actions to influence the policies and activities of other sectors to give due consideration to social, environmental and economic determinants of health» ${ }^{5}$.

The health care system (managed by the Ministry of Health) plays a central role in the management of public health and the provision of public health services. Thus, public health care is also directly relevant to health care systems, and these systems, in their turn, can only be effective if they have a strong component associated with public health services.

Ten EPHOs are proposed in a form of detailed list to evaluate the potential and services of the public health system and the actions needed to improve them. They are among the most important services in the public health system (EPHOs 1-5), and are relevant to all aspects (EPHOs 6-10) and contribute to the implementation of EPHOs 1-5. The EPHOs are not expected to be considered as 10 separate services. They can be adapted according to different conditions and performed in groups or blocks. For example, EPHOs 1 and 2 mainly relate to analytical information on public health that can be used in the process of problem solving regarding health care and promotion and disease prevention (EPHOs 3-5), while EPHOs 6-10 are intended to facilitate improving service delivery as a whole.

The seventh essential public health operation is to provide the public health area with sufficient number of qualified personnel.

\footnotetext{
${ }^{5}$ Sistemy zdravookhraneniya - zdorov'e - blagosostoyanie: Evropeyskaya ministerskaya konferentsiya VOZ po sistemam zdravookhraneniya (2008) [Health systems - Health Welfare: WHO European Ministerial Conference on Health Systems]. Tallinn, Estonia. Report (2009) Copenhagen: WHO Regional Office for Europe. Retrieved from: http://www.euro.who.intassets/pdf_file/0003/78951/E92150 R.pdf.
} 
WHO has adopted a number of important instruments that should contribute to the development of public health system in the region and in Ukraine directly $^{6}$, .

In Ukraine, the formation of a new public health service is conformed with program international and national documents, first of all with the Sustainable Development Strategy «Ukraine 2020» ${ }^{8}$, approved by the Decree of the President of Ukraine of January 12, 2015, the Association Agreement between Ukraine and the EU, section 22 of which outlines the priority tasks and courses of activity in the field of public health ${ }^{9}$. Institutional formation of the national public health service is conducted in accordance with the Concept for Development of the Public Health System, approved by the Decree of the Cabinet of Ministers of Ukraine of November 30, 2016 № 1002-p. ${ }^{10}$ and Action Plan for the Implementation of the Concept for Development of the Public Health System, approved by the Decree of the Cabinet of Ministers of Ukraine of August 18, 2017 No. 560-p. ${ }^{11}$ The Concept defines the courses, mechanisms and timing of the formation of public health system, with the aim of developing and implementing effective

${ }^{6}$ Komissiya po sotsial'nym determinantam zdorov'ya. Likvidirovat' razryv $\mathrm{v}$ techenie zhizni odnogo pokoleniya. Soblyudenie printsipa spravedlivosti v zdravookhranenii putem vozdeystviya na sotsial'nye determinanty zdorov'ya (2009) [Commission on Social Determinants of Health. Closing the gap in a generation. Health equity through action on the social determinants of health]. Final report of the Commission on the Social Determinants of Health. Geneva, WHO. Retrieved from: http://www.who.int/social_determinants/ thecommissionfnalreport/ru/index.html.

7 Rezolyutsiya WHA62.14 Vsemirnoy assamblei zdravookhraneniya "Umen'shenie nespravedlivosti v otnoshenii zdorov'ya posredstvom vozdeystviya na sotsial'nye determinanty zdorov'ya" (2009) [Resolution WHA62.14 of World Health Assembly «Reducing health inequities through action on the social determinants of health»]. Geneva, WHO. Retrieved from: http://apps.who.int/gb/or/r/r_wha62r1.html..

8 Pro Strateghiju stalogho rozvytku «Ukrajina - 2020», Ukaz Prezydenta Ukrajiny № 5/2015 vid 12.01.2015 [On the Sustainable Development Strategy «Ukraine 2020», Presidential Decree № 5/2015 of 12.01.2015]. Retrieved from: https://zakon.rada.gov.ua/laws/ show/5/2015

${ }^{9}$ Ughoda pro asociaciju mizh Ukrajinoju ta JeS: zmist ta implementacija [EU-Ukraine Association Agreement: content and implementation.]. Retrieved from: https://parlament.org.ua/ upload/docs/final_1.pdf

10 Pro skhvalennja Koncepciji rozvytku systemy ghromadsjkogho zdorov'ja, Rozporjadzhennja Kabinetu Ministriv Ukrajiny №1002-r. vid 30.11.2016 [On approval of the Concept of development of the public health system, Order of the Cabinet of Ministers of Ukraine №1002-p. of 30.11.2016]. Retrieved from: https://zakon.rada.gov.ua/laws/show/10022016-\%D1\%80

${ }^{11}$ Pro zatverdzhennja planu zakhodiv shhodo realizaciji Koncepciji rozvytku systemy ghromadsjkogho zdorov’ja, Rozporjadzhennja Kabinetu Ministriv Ukrajiny № 560-r vid 18.08.2017 [On Approval of the Action Plan for the Implementation of the Concept of Public Health System Development, Order of the Cabinet of Ministers of Ukraine № 560-p of 18 August 2017]. Retrieved from: https://zakon.rada.gov.ua/laws/show/560-2017-\%D1\%80 
public policies to promote health, prevent diseases, extend active and working age and encourage healthy lifestyles through the united efforts of the entire society.

Further work in the country is aimed at providing the public health system with qualified personnel. So, in 2015 the CMU approved the specialty «Public Health» ${ }^{12}$, and subsequently the Ministry of Education and Science of Ukraine approved educational standards for training of bachelors and masters ${ }^{13}$ in the specialty «Public Health».

A significant step in human resourcing of the newly created service was inclusion of the specialty «Public health» into the list of specialties available for the students of higher educational institutions, according to the Decree of the Cabinet of Ministers of Ukraine dated 01.02.2017 No. 53 «On Amendments to the Decree of the Cabinet of Ministers of Ukraine dated April 29, 2015 No. 266» ${ }^{14}$.

The Ministry of Health included in the Action Plan for the Implementation of the Concept on Development of the Public Health System in Ukraine the task of ensuring the development of the National Plan for the Development of Human Resources in the Public Health System, which will include the issues of education and training, mobility, career opportunities and development and approval of educational standards and educational programs, taking into account the best European and international experience in the specialty «Public Health» to provide three-level training (Bachelor's degree, Master's degree) and continuing professional development. In addition, the conceptual framework for the development of a model of public health education and training includes the task of shaping the future public health potential in line with changes and threats to public health at national and European levels, based on the best foreign education

${ }^{12}$ Pro zatverdzhennja pereliku ghaluzej znanj i specialjnostej, za jakymy zdijsnjujetjsja pidghotovka zdobuvachiv vyshhoji osvity, Postanova Kabinetu Ministriv Ukrajiny № 266 vid 29.04.2015 [On approval of the list of specialties for which higher education students are trained, Resolution of the Cabinet of Ministers of Ukraine № 266 of 29.04.2015]. Retrieved from: http://zakon4.rada.gov.ua/laws/ show/266-2015-п.

13 Pro zatverdzhennja standartu vyshhoji osvity za specialjnistju 229 «Ghromadsjke zdorov'ja» dlja drughogho (maghistersjkogho) rivnja osvity, Nakaz Ministerstva osvity i nauky Ukrajiny №1383 vid 12.12.2018 [On approval of the higher education standard in the specialty 229 «Public Health» for the second (Master's) degree of education, Order of the Ministry of Education and Science of Ukraine № 1383 of 12.12.2018]. Retrieved from: https://mon.gov.ua/ storage/app/media/vishcha-osvita/rekomendatsii-1648.pdf

${ }^{14}$ Pro vnesennja zmin do postanovy Kabinetu Ministriv Ukrajiny vid 29 kvitnja 2015 r. №266, Postanova Kabinetu Ministriv Ukrajiny №53 vid 01.02.2017 [On Amendments to the Resolution of the Cabinet of Ministers of Ukraine of April 29, 2015 No. 266, Resolution of the Cabinet of Ministers of Ukraine № 53 of 01.02.2017]. Retrieved from: https://zakon.rada.gov.ua/laws/show/53-2017-\%D0\%BF\#n2 
standards, researches and practice in the area of public health. The basis for the development of the above standard, plan and program were documents from WHO, WHO European Region, Association of Schools of Public Health in the European Region (ASPHER), Agency for Public Health Education Accreditation (APHEA), national strategy documents, best European experience.

The implementation of human resources policy should be aimed at various aspects: social - high level of development of human potential, meeting the expectations of the population for professional self-realization, decent pay; and economic - provision of all industries and sectors with qualified personnel, increasing the competitiveness of state, improving the level of welfare of the population.

The training of specialists in «Public Health» involves the formation of a new generation of professionals for public administration, local government, economic entities of various forms of ownership, including nongovernmental organizations in the field of public health. This would contribute to the improvement and implementation of the state policy aimed at solving the problems related to the worsening of medical-demographic situation in the country, inequality of access to health-saving and healthforming technologies and services, dissatisfaction of a considerable part of citizens with the state of medical care and protection of patients' rights, the necessity of development of cross-sectoral and inter-sectoral cooperation on public health in Ukraine in compliance with the national principle «health care in all state policies».

In particular, the training of specialists for educational degree of Bachelor is aimed at training specialists capable of solving complex tasks and problems in the field of public health or in learning process, which involves the application of certain theories and methods of the relevant science and is characterized by uncertainty of conditions and requirements.

The educational standard for the second educational degree (Master's degree) includes the objects of study, theoretical content of the subject area of study, methods and more. The objectives of Master's program are to acquire knowledge and skills in assessing health of the population and the determinants that influence it, as well as to develop and implement policies and measures aimed at preserving, promoting health and social well-being of the population.

The standard specifies that the training of specialists in Master's degree in the specialty 229 «Public Health» is carried out on the basis of the first (Bachelor's) and/or second (Master's) or equivalent level of higher education without limiting the specialty. 
At the same time, for the Master in specialty 229 «Public Health» on the basis of the first (Bachelor`s) level, the volume of educational-scientific (educational and professional) program constitutes 120 ECTS credits. A minimum of $35 \%$ of educational program scope should be aimed at acquisition of general and special (professional) competences in the specialty, defined by the Standard. It should be noted that competency formation was carried out taking into account the competences of public health professionals in the European Region ${ }^{15}$.

The integral competence of a Master in «Public Health» defines the ability to solve complex tasks and problems in public health or in learning process, which involves researches, application of scientific theories and analytical methods and is characterized by the complexity and uncertainty of the conditions.

In 2018, the first enrolment of students for Bachelor's degree and in 2019 - for Master`s degree was carried out in Ukraine.

In 2019, with a licensed amount of 550 students, 38 students were enrolled, including 5 under government order for budget funds. The Bachelor studies in «Public Health» are provided by the National University of Ostroh Academy and Sumy State University.

To prepare public health professionals under Master's program, with a licensed amount of 740 students, 52 students were admitted to higher education institutions, including 18 by government order. In Uzhhorod National University, 18 students have been admitted to the Master's program in the specialty «Public Health», 10 of them by government order. Masters in «Public Health» are trained by State Higher Educational Institution «Uzhhorod National University», I. Horbachevsky Ternopil State Medical University of the Ministry of Health of Ukraine, Kharkiv National Medical University, Municipal Higher Educational Institution «Zhytomyr Medical Institute» of Zhytomyr Regional Council.

Considering the largest number of students who are studying under Master's program in «Public Health» at Uzhhorod National University, we have researched and analysed the system of their preparation in this higher educational institution.

In accordance with the state standard for education under Master's program on a full-time basis the students were enrolled according to the

${ }^{15}$ Foldspengh A., Birt K., Otok R., (ed.). (2018). Perelik osnovnykh kompetencij fakhivciv ghromadsjkogho zdorov'ja Asociaciji uchbovykh zakladiv ghromadsjkogho zdorov'ja $v$ Jevropejsjkomu reghioni (ASPHER) [List of basic competences of public health professionals according to Association of Schools of Public Health in the European Region (ASPHER)]. Vol. 5. Brussels. 
principle of «cross-Master studies», having Bachelor's degree in the specialties «Human Health» and «Physical Culture and Sports». For studying under Master's program on a part-time basis the students were enrolled, having the first higher education in the specialty «Political Science» and «Medicine».

The positive aspect of preparation of Masters in the specialty «Public Health» at classical university, like Uzhhorod National University, is the presence of nonspecialized faculties and departments where professors can be involved in the preparation of Masters. An example of involving such specialists from other departments to formulate the competencies of future public health workers is given in Figure 1.

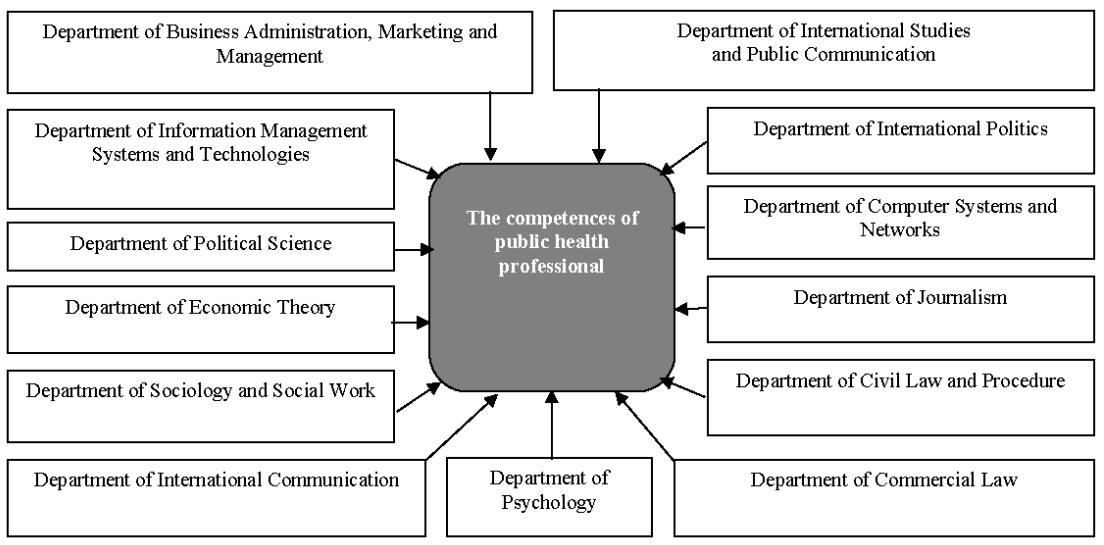

\section{Fig. 1. Departments professors of which can be involved in the preparation of Masters in «Public Health»}

\section{Analysis of training of public health professionals}

At Uzhhorod National University the educational and scientific program for Master's degree in the specialty 229 «Public Health» was developed in accordance with the requirements of the Law of Ukraine «On Higher Education» of 01.07.2014. № 1556-VII ${ }^{16}$. The Master's degree program in the specialty «Public Health» consists of 5 compulsory modules: introduction to public health, and public health system, policies, ethics,

16 Pro vyshhu osvitu, Zakon Ukrayiny №1556-VII vid 01.07.2014 [«About Higher Education», Law of Ukraine № 1556-VII of 01.07.2014]. Retrieved from: https://zakon.rada.gov.ua/laws/show/1556-18. 
management and leadership in the field of public health; epidemiology and biostatistics for public health professionals; monitoring and evaluation, data quality, data use and public health information; program planning, its implementation and evaluation; Business English; as well as 4 modules, one of which the Master chooses independently.

The Master's degree program is designed for 3600 hours (120 ECTS credits). The lecture course provides 462 academic hours. 512 academic hours were allocated for conducting seminars, 1318 academic hours - for practical classes, 1308 (36.3\%) academic hours - independent work. Independent work for preparation of Master's qualification work (thesis) includes 700 academic hours. Of the total number of academic hours, 30 hours are allocated to module control and 6 hours - to examinations ${ }^{17}$.

The structure of a discipline is shown in Figure 2.

\begin{tabular}{|c|c|c|c|c|c|}
\hline \multicolumn{4}{|c|}{ Classroom hours } & \multirow{2}{*}{$\begin{array}{c}\text { Independent } \\
\text { work }\end{array}$} & \multirow[b]{2}{*}{ Type of control } \\
\hline Total & Lectures & Seminars & $\begin{array}{c}\text { Practical } \\
\text { classes }\end{array}$ & & \\
\hline 3600 & 462 & 512 & 1318 & 1308 & $\begin{array}{l}\text { Oral questioning. } \\
\text { Solution of } \\
\text { situational } \\
\text { problems. } \\
\text { Module test } \\
\text { control. } \\
\text { Computer test. }\end{array}$ \\
\hline \multicolumn{5}{|c|}{ Total ECTS credits } & 90 \\
\hline \multicolumn{6}{|c|}{ including: } \\
\hline \multicolumn{5}{|c|}{ Scientific research work } & Type of control \\
\hline \multicolumn{2}{|c|}{ Credits } & 30 & \multicolumn{2}{|c|}{$\begin{array}{l}\text { Undertaking a scientific } \\
\text { independent research and } \\
\text { preparation of scientific } \\
\text { master's thesis }\end{array}$} & $\begin{array}{l}\text { Public defense of } \\
\text { scientific master's } \\
\text { thesis }\end{array}$ \\
\hline
\end{tabular}

\section{Fig. 2. The structure of the discipline «Public Health» at Uzhhorod National University}

Teaching methods include lectures and seminars, classes using remote method with the aid of Moodle system, practical classes on specific topics, including visits to practical public health facilities, preparation by masters of analytical reviews of scientific literature on specific topics, preparation of analytical materials describing medical-demographic situation in the region,

${ }^{17}$ Slabkyj Gh.O., Shafransjkyj V.V., Myronjuk I.S. (2017) Pytannja pidghotovky fakhivciv dlja sfery ghromadsjkogho zdorov'ja [Issues of Training Public Health Professionals]. Ukrajina. Zdorov’ja naciji. №3 (44), pp. 32-55. 
conducting business games, as well as independent implementation of research work, writing a scientific Master's thesis and its defence. In order to ensure that the necessary competences are acquired by the masters, the program is divided into disciplines. This division is presented in Fig. 3.

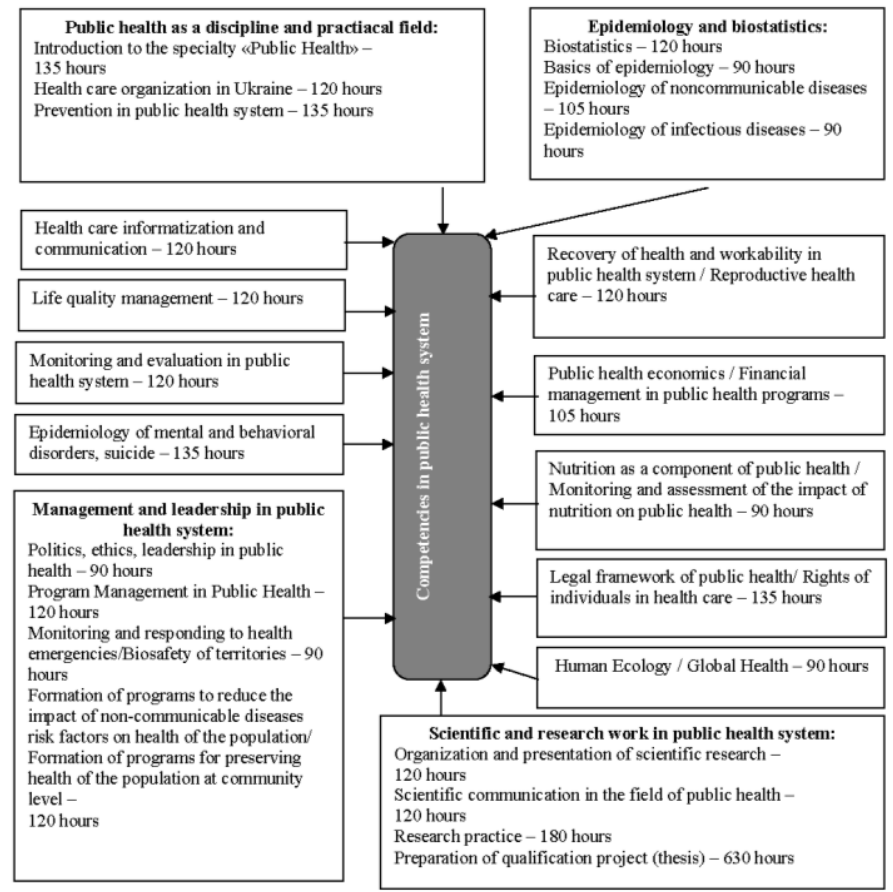

Fig. 3. Division of educational program into disciplines

The purpose of the Master's degree program in «Public Health» is to prepare specialists in this field for independent practical and scientific and pedagogical activity in accordance with certain competencies. The professional and scientific program provides for the formation of the ability to apply the acquired knowledge, abilities and skills on disciplines of general and professional training to solve typical tasks of the specialist's activity at relevant position or post, including conducting scientific-practical researches in the field of public health, teaching the subject «Public Health», conducting epidemiological surveillance of socially significant infectious and non-communicable diseases, the state of mental health of the population, 
environment; determination of environmental, socio-economic and medical determinants of health; organization and implementation of preventive and anti-epidemic measures; promoting healthy lifestyle and responsible attitude to a person's health; cross-sectoral cooperation for the sake of public health.

The program stipulates that working and educational practice, research work are carried out in accordance with the curriculum of Master's program in the specialty «Public Health» and are obligatory and present a type of educational activities directly oriented to professional and scientific training of students. Working and educational practice and research work consolidate the knowledge and skills acquired during mastering of theoretical disciplines and help students to develop practical skills and contribute to comprehensive formation of general and professional competences. In the course of learning Master's curriculum in the specialty «Public Health», students are expected to undergo working and educational practice and perform research work.

Practice bases are healthcare institutions, public health institutions, which have the necessary human and scientific and technical resources, the main activity of which has the object and types of professional activity of graduates in the specialty «Public Health».

The purpose of practice is acquisition by masters of experience and skills of collective and independent professional activity in the field of public health, including the assessment and monitoring of the state of health of the population, conducting research aimed at identifying factors that determine public health, the development of scientifically sound measures to preserve and promote health of the population, put them into practice and evaluate their effectiveness.

As a result of practice, the learner must acquire the following practical skills and competences: independent choosing and justification of the topic, purpose and objectives of the research, choosing and justification of the method and scope, which are adequate to the tasks; development of practical projects on pressing public health problems; mastering new theories, models, research methods, developing new methodological approaches and technologies; organization and participation in the assessment of the state of health of the population, epidemiological situation, the external environment; - planning and carrying out actions on health care and environmental protection, improvement of health of the population, organization of management in the field of public health; collecting and analysing public health information using modern methods of automated information collection and processing; processing and analysis of the obtained data with the help of modern information technologies; preparation 
and execution of scientific and technical projects and reports, normative and methodological documents.

Within the framework of the implementation of Master's curriculum in the specialty «Public Health», research work is also envisaged. Also preparation and defence of scientific master's project (thesis). The bases of the research work are departments, research institutions in this area of training and public health institutions with the necessary resources for the research.

The purpose of scientific and research work, performed by the masters, is to expand the acquired and new knowledge, test scientific hypotheses, establish patterns existing in nature, society, scientific generalization, scientific substantiation of projects.

A Master should know: the main directions and problems of research in public health area; structure of research, medical, preventive and public health institutions; organization of work of departmental and scientific units; computer operation safety rules; rules for collecting primary information; rules for processing and presentation of research results.

A Master should be able to: work with scientific literature on the chosen problem; set tasks, select adequate research methods and determine the size of sample amount of a research; analyse the data obtained from scientific research; make adjustments to research design; formulate conclusions and practical recommendations on the results of scientific research; to formulate the basic provisions of scientific qualification works: relevance, purpose, tasks, object, subject, methods of research, novelty, basic statements that are brought to the defence, theoretical and practical importance of a thesis.

A Master should have: skills of searching and generalization of sources of scientific literature; technology of planning and execution of research work at its various stages.

With a view to preparing masters at the University since September 1, 2019, the Department of Health Sciences was opened and its staffing list and personnel was formed.

The department has among its employees a doctor, $\mathrm{PhDs}$ and specialists with extensive practical experience related to the provision of services that are characteristic of public health system, including specialists in the organization and management of health care, epidemiology, monitoring and evaluation, sociology, social work and practical psychology, information technology and communication.

Having a considerable potential, during the preparation of masters, the teaching staff of the department faces a number of problems. The most important of these are: 
- lack of modern national educational and methodological developments for conducting classes on the topics defined by the program;

- lack of a state system of assessment of knowledge acquired by students during their studies under Master's program;

- the lack of masters who were enrolled to study in Master`s program on the principle of "cross-Master studies», the necessary basic knowledge to master certain subjects, such as «Epidemiology».

An important problem for both students and teachers is that the public health system is just being created. In some regions, including Transcarpathian region, Public Health Centers are not established and students are not able to anticipate their first place of work, and accordingly their specialization and list of priority competencies.

These problems are the subject to solution at all levels of management from the central (Ministry of Health of Ukraine and Ministry of Education and Science of Ukraine) to the basic level of higher education institutions and united communities.

\section{CONCLUSIONS}

In order to implement «European Action Plan for Strengthening of Public Health Capacities and Services», a public health system is being created in Ukraine, which needs qualified personnel. The Cabinet of Ministers of Ukraine approved the specialty «Public Health» and the Ministry of Education and Science of Ukraine approved national educational standards for training students for Bachelor's and Master's degrees. The licensed number of trained specialists in the amount of annual admission of students for preparation of Bachelor's degree - 550 persons and Master's degree -740 persons was also approved.

The enrolment of students in 2019 for mastering specialty «Public Health» (Bachelor's degree 6.9\% of the licensed number, Master's degree $7.0 \%$ of the licensed number) indicates that this specialty is not favourable one among entrants. The low demand for specialty «Public Health» is due to the lack of information on post-graduation employment. Training of future specialists is carried out in accordance with the requirements of the Law of Ukraine «On Higher Education» of 01.07.2014, № 1556-VII and in accordance with the state standard.

The educational program for obtaining Master's degree in the specialty «Public Health» consists of 5 compulsory modules: introduction to public health, and public health system, policies, ethics, management and leadership in the field of public health; epidemiology and biostatistics for public health professionals; monitoring and evaluation, data quality, data use 
and public health information; program planning, its implementation and evaluation; Business English; as well as 4 modules, one of which master chooses independently.

The educational program for obtaining Master's degree is designed for 3600 hours (120 ECTS credits). The lecture course provides 462 academic hours.

512 academic hours were allocated for conducting seminars, 1318 academic hours - for practical classes, 1308 (36.3\%) academic hours independent work. Independent work for preparation of Master's qualification work (thesis) includes 700 academic hours. Of the total number of academic hours, 30 hours are allocated to module control and 6 hours - to examinations.

The problems in organization of the educational process are the lack of modern national educational and methodological developments for conducting classes on the topics defined by the program, the state system of knowledge assessment acquired by students during their Master studies, and the lack by Masters enrolled on the basis of principle of «cross-Master studies», the necessary basic knowledge to master certain subjects.

Existing problems need to be addressed at all levels of management, from central to basic - united communities and higher education institutions.

\section{SUMMARY}

Ukraine experiences the formation of a public health system based on international approaches. In order to ensure its effective functioning in the country, the specialty «Public Health» was approved and training of specialists of the first educational level - Bachelor's degree and the second educational level - Master's degree began. State educational standards for the training of specialists in the field of public health system have been approved. Licensed number for training of specialists have also been approved. The enrolment of students in 2019 for mastering specialty «Public Health» (Bachelor's degree 6.9\% of the licensed number, Master's degree $7.0 \%$ of the licensed number) indicates that this specialty is not favourable one among entrants. The low demand for specialty «Public Health» is due to the lack of information on post-graduation employment.

Training of future specialists is carried out in accordance with the state standard, but there is no modern educational and methodological support in educational institutions. 


\section{REFERENCES}

1. Zdorov'e - 2020. Osnovy evropeyskoy politiki i strategiya dlya XXI veka (2013) [Health - 2020. European policy framework and strategy for the 21st century]. Retrieved from: http://www.euro.who.int/ PubRequest?language $=$ Russian.

2. Acheson D. (1988) Public health in England: the report of the Committee of Inquiry into the Future Development of the Public Health Function. London, H. M. Stationery Office.

3. Evropeyskiy plan deystviy po ukrepleniyu potentsiala i uslug obshchestvennogo zdravookhraneniya (2012) [European Action Plan for Strengthening of Public Health Capacities and Services]. Copenhagen: WHO Regional Office for Europe, (document EUR/RC62/12).

4. Slabkyj Gh.O., Myronjuk I.S., Kachala L.O. (2017) Systema ghromadsjkogho zdorov'ja: bachennja Vsesvitnjoji orghanizaciji okhorony zdorov'ja, Osnovni operatyvni funkciji ghromadsjkogho zdorov'ja ta jikh zmist [Public Health System: World Health Organization Vision, Essential Public Health Functions and Their Meaning]. Ukrajina. Zdorov'ja naciji, no. 3 (44), pp. 24-31.

5. Sistemy zdravookhraneniya - zdorov'e - blagosostoyanie: Evropeyskaya ministerskaya konferentsiya VOZ po sistemam zdravookhraneniya (2008) [Health systems - Health - Welfare: WHO European Ministerial Conference on Health Systems]. Tallinn, Estonia. Report (2009) Copenhagen: WHO Regional Office for Europe. Retrieved from: http://www.euro.who.intassets/pdf_file/0003/78951/E92150 R.pdf.

6. Komissiya po sotsial'nym determinantam zdorov'ya. Likvidirovat' razryv $\mathrm{v}$ techenie zhizni odnogo pokoleniya. Soblyudenie printsipa spravedlivosti $\mathrm{v}$ zdravookhranenii putem vozdeystviya na sotsial'nye determinanty zdorov'ya (2009) [Commission on Social Determinants of Health. Closing the gap in a generation. Health equity through action on the social determinants of health]. Final report of the Commission on the Social Determinants of Health. Geneva, WHO. Retrieved from: http://www.who.int/ social_determinants/thecommissionfnalreport/ru/index.html.

7. Rezolyutsiya WHA62.14 Vsemirnoy assamblei zdravookhraneniya “Umen'shenie nespravedlivosti $\mathrm{v}$ otnoshenii zdorov'ya posredstvom vozdeystviya na sotsial'nye determinanty zdorov'ya" (2009) [Resolution WHA62.14 of World Health Assembly «Reducing health inequities through action on the social determinants of health»]. Geneva, WHO. Retrieved from: http://apps.who.int/gb/or/r/r_wha62r1.html.

8. Pro Strateghiju stalogho rozvytku «Ukrajina - 2020», Ukaz Prezydenta Ukrajiny № 5/2015 vid 12.01.2015 [On the Sustainable 
Development Strategy «Ukraine 2020», Presidential Decree № 5/2015 of 12.01.2015]. Retrieved from: https://zakon.rada.gov.ua/laws/ show/5/2015

9. Ughoda pro asociaciju mizh Ukrajinoju ta JeS: zmist ta implementacija [EU-Ukraine Association Agreement: content and implementation.]. Retrieved from: https://parlament.org.ua/upload/ docs/final_1.pdf

10. Pro skhvalennja Koncepciji rozvytku systemy ghromadsjkogho zdorov'ja, Rozporjadzhennja Kabinetu Ministriv Ukrajiny № 1002-r. vid 30.11.2016 [On approval of the Concept of development of the public health system, Order of the Cabinet of Ministers of Ukraine №1002-p. of 30.11.2016]. Retrieved from: https://zakon.rada.gov.ua/laws/show/10022016-\%D1\%80

11. Pro zatverdzhennja planu zakhodiv shhodo realizaciji Koncepciji rozvytku systemy ghromadsjkogho zdorov'ja, Rozporjadzhennja Kabinetu Ministriv Ukrajiny № 560-r vid 18.08.2017 [On Approval of the Action Plan for the Implementation of the Concept of Public Health System Development, Order of the Cabinet of Ministers of Ukraine № 560-p of 18 August 2017]. Retrieved from: https://zakon.rada.gov.ua/laws/show/5602017-\%D1\%80

12. Pro zatverdzhennja pereliku ghaluzej znanj i specialjnostej, za jakymy zdijsnjujetjsja pidghotovka zdobuvachiv vyshhoji osvity, Postanova Kabinetu Ministriv Ukrajiny № 266 vid 29.04.2015 [On approval of the list of specialties for which higher education students are trained, Resolution of the Cabinet of Ministers of Ukraine № 266 of 29.04.2015]. Retrieved from: http://zakon4.rada.gov.ua/laws/ show/266-2015-п.

13. Pro zatverdzhennja standartu vyshhoji osvity za specialjnistju 229 «Ghromadsjke zdorov'ja» dlja drughogho (maghistersjkogho) rivnja osvity, Nakaz Ministerstva osvity i nauky Ukrajiny №1383 vid 12.12.2018 [On approval of the higher education standard in the specialty 229 «Public Health» for the second (Master's) degree of education, Order of the Ministry of Education and Science of Ukraine № 1383 of 12.12.2018]. Retrieved from: https://mon.gov.ua/ storage/app/media/vishcha-osvita/rekomendatsii1648.pdf

14. Pro vnesennja zmin do postanovy Kabinetu Ministriv Ukrajiny vid 29 kvitnja 2015 r. № 266, Postanova Kabinetu Ministriv Ukrajiny № 53 vid 01.02.2017 [On Amendments to the Resolution of the Cabinet of Ministers of Ukraine of April 29, 2015 No. 266, Resolution of the Cabinet of Ministers of Ukraine № 53 of 01.02.2017]. Retrieved from: https://zakon.rada.gov.ua/laws/show/53-2017-\%D0\%BF\#n2 
15. Foldspengh A., Birt K., Otok R., (ed.). (2018). Perelik osnovnykh kompetencij fakhivciv ghromadsjkogho zdorov'ja Asociaciji uchbovykh zakladiv ghromadsjkogho zdorov'ja v Jevropejsjkomu reghioni (ASPHER) [List of basic competences of public health professionals according to Association of Schools of Public Health in the European Region (ASPHER)]. Vol. 5. Brussels.

16. Pro vyshhu osvitu, Zakon Ukrayiny №1556-VII vid 01.07.2014 [«About Higher Education», Law of Ukraine № 1556-VII of 01.07.2014]. Retrieved from: https://zakon.rada.gov.ua/laws/show/1556-18.

17. Slabkyj Gh.O., Shafransjkyj V.V., Myronjuk I.S. (2017) Pytannja pidghotovky fakhivciv dlja sfery ghromadsjkogho zdorov'ja [Issues of Training Public Health Professionals]. Ukrajina. Zdorov'ja naciji. № 3 (44), pp. 32-55.

\section{Information about the author:}

Bilak-Lukianchuk V. Yo., orcid.org/0000-0003-3020-316X Associate Professor at the Department of Health Sciences,

Uzhhorod National University 29, Mytna str., 88000, Uzhhorod, Ukraine 
DOI https://doi.org/10.36059/978-966-397-155-1/44-61

\section{CHARACTERISTICS OF TRAUMATISM OF THE POPULATION OF TRANSCARPATHIAN REGION}

\section{Brych V. V.}

\section{INTRODUCTION}

The health of the population always occupies the most important part in the welfare system of the state. Recently, chronic noncommunicable diseases have been increasingly recognized as a major contributor to public health. However, less attention has been paid to injuries, which also have a significant impact on health, morbidity, disability and mortality.

Injuries, whether intentional or unintentional, are the third leading cause of death in the World Health Organization (WHO) European Region and pose a threat to economic and social development ${ }^{1}$. In general, injuries are a major cause of death of people aged 5-49 years, and the death rate from injury is 2,4 times higher in low- and middle-income countries compared with high-income countries. Injuries also exacerbate disease burden, measured in disability-adjusted life years (DALY) or years of healthy living, lost as a result of premature death or disability. In 2015, the injury-related burden that caused the loss of 28 million DALY represented $9.4 \%$ of all DALY lost ${ }^{2}$.

Traumatism is a combination of injuries that occur over a certain period of time in a certain territory among a certain population group. The following are considered the main types of injury in Ukraine: traffic road, occupational, domestic, sports and street injuries.

The incidence of the category of diseases «Injury, poisoning and certain other consequences of external causes (S00-T98)» in Ukraine in recent years has been more stable, ranging from 4023 to 100 thousand

\footnotetext{
${ }^{1}$ Sethi D, Mitis F, Racioppi F. (2010). Preventing injuries in Europe: from international collaboration to local implementation. Copenhagen: WHO Regional Office for Europe. Retrieved from: http://www.euro.who.int/en/publications/ abstracts/preventing-injuries-ineurope-from-international-collaboration-to-localimplementation.

${ }^{2}$ Aldridge E, Sethi D. Yon Y. (2017). Injuries: a call for public health action in Europe. Copenhagen: WHO Regional Office for Europe. Retrieved from: http://www.euro.who.int/ data/assets/pdf_file/0018/348102/WH08_IJ_complete-web-version.pdf?ua=1 
people in $2014^{3}$ to 4010 in 2017 , while in 2000 and 2010 this figure was 4749 and 4853 per 100 thousand population respectively ${ }^{4}$. Despite the fact that the share of the above category in the structure of the general morbidity of the population of Ukraine is small (6-6,5\%), it remains one of the main causes of disability.

Occupational traumatism occupies a special place. In Ukraine the situation in the field of labor protection has remained tense in recent years. The current Occupational Health and Safety Management System has proved to be insufficient in the current conditions. As a consequence, the level of injuries in the workplace remains relatively high ${ }^{5}$.

Medical and social impact of injury is significant not only because of its spread and high mortality rate, but also because injuries cause significant economic losses to industries, leading to increased costs of healthcare, social benefits and improving quality of life for people with disabilities.

Special attention is given to the westernmost region of Ukraine, the Transcarpathian region, which is characterized by certain features: the predominance of rural population $(63 \%)$, borderline placement (it borders with 4 other countries), a large number of villages with the status of mountain settlements, recurrent natural disasters such as floods, massive migration to other regions of Ukraine and abroad, and so on. This can lead to increased traumatism and therefore require taking special measures for injury prevention and medical care, including rehabilitation.

Trauma management has 2 main components: trauma prevention and trauma care, including rehabilitation. To ensure the full implementation of these components in the regions, it is necessary to understand the main trends in the epidemiology of trauma in the target area.

It should be emphasized that the best conditions for collecting information on all injuries requiring outpatient medical intervention, observation and/or hospital treatment, as well as for objective assessment

3 Derzhavna sluzhba statystyky Ukrainy (2017) Zaklady okhorony zdorov'ja ta zakhvorjuvanistj naselennja Ukrajiny u 2016 roci [Healthcare institutions and the incidence of the population of Ukraine in 2016], Kyiv. Retrieved from: http://www.ukrstat.gov.ua/ druk/publicat/kat_u/2016/bl/06/bl_zoz_15xl.zip

4 Derzhavna sluzhba statystyky Ukrainy (2018) Zaklady okhorony zdorov'ja ta zakhvorjuvanistj naselennja Ukrajiny u 2017 roci [Healthcare institutions and the incidence of the population of Ukraine in 2017], Kyiv. Retrieved from: http://www.ukrstat.gov.ua/ druk/publicat/kat_u/2018/zb/06/zb_zoz_17.pdf

5 Dmytrjuk S. P., Ghodjajev S. Gh. (2017). Osnovni prychyny ta metody analizu pokaznykiv vyrobnychogho travmatyzmu [Principal reasons and methods of analysis of indexes of production traumatism of]. Budivnyctvo, materialoznavstvo, mashynobuduvannja. Zb. nauk. pracj. [Construction, materials science, mechanical engineering], vol. 101, pp.94-99. 
and identification of the most serious cases with serious consequences, can only be ensured by a network of health care institutions ${ }^{6}$. In order to plan injury prevention measures in a particular region of Ukraine, the Transcarpathian region, it was decided to analyze the dynamics and the state of the spread of different types of injuries in the region. Therefore, we have analyzed statistical reference «Network of institutions and key indicators of the health system in the Transcarpathian region» for 2014-2018.

\section{Injury and its structure in the Transcarpathian region in 2014-2018}

The current state of health care in Ukraine is extremely unsatisfactory. According to WHO, Ukraine has entered the so-called «red zone». In 2017 noncommunicable diseases killed 605,000 people in Ukraine, which is approximately $90 \%$ of all deaths ${ }^{7}$. Of course, these nationwide tendencies are observed in all regions of Ukraine; however, it should be noted that the Transcarpathian region is characterized by its peculiarities. They are related to geographical, socio-economic and cultural features that have formed historically.

Despite the poor state of health of the population, there has been a trend in Ukraine and the Transcarpathian region in particular of overall morbidity reduction over the last three years (2016-2018). Thus, in 2016 the levels of general morbidity increased to 64375 per 100 thousand population in Ukraine and 61084.6 per 100 thousand in the Transcarpathian region compared to 2014 (62759,0 and 60007,7 respectively) and 2015 (62775,0 and 60615,1 respectively); however, in 2017 and 2018 in the Transcarpathian region they reduced to 58729,9 and 57469,3 per 100 thousand population respectively, while in Ukraine they reduced to 62895 per 100 thousand population in 2017 (Fig. 1).

Recently, the most widespread chronic noncommunicable diseases and socially dangerous infectious diseases have received increasing attention in all regions of Ukraine. However, injury as an important component of health problems and disability in population remains neglected, though it can significantly affect the working age population.

In order to study the injury situation, we have analyzed the level of total injuries in the Transcarpathian region and their structure (Table 1).

6 Lazebnyk Ju. O. (2018). Proghramno-metodologhichni zasady udoskonalennja nacionaljnoji systemy sposterezhennja zi statystyky travmatyzmu [Program-methodological Principles of Improvement of the National System of Statistical Observation of Traumatism]. Statistics of the Ukraine, no. 3, pp. 49-58.

${ }^{7}$ Barannyk L. B. (2019) Zdorov'ja naselennja jak indykator rozvytku socialjnogho kapitalu v Ukrajini [Public health as an indicator of the social capital development in Ukraine]. Scientific Notes of Ostroh Academy National University, «Economics» series, no. 12, pp. 64-69. Retrieved from: http://nbuv.gov.ua/UJRN/Nznuoa_2019_12_12. 


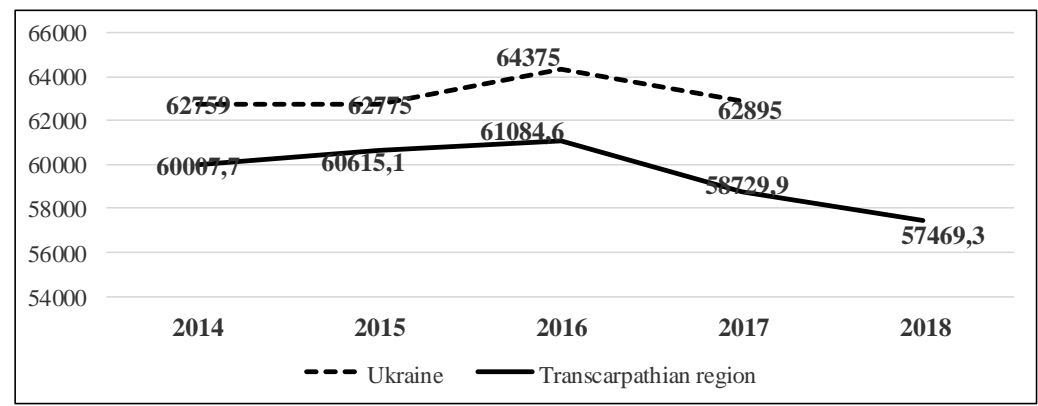

Fig. 1. Morbidity rates in Ukraine and Transcarpathian region in 2014-2018 (per 100000 population)

Table 1

Injury rate of the entire population of the Transcarpathian region in 2014-2018 (per 100 thousand population)

\begin{tabular}{|c|c|c|c|c|c|}
\hline \multirow{2}{*}{ Type of injury } & \multicolumn{5}{|c|}{ Years } \\
\cline { 2 - 6 } & $\mathbf{2 0 1 4}$ & $\mathbf{2 0 1 5}$ & $\mathbf{2 0 1 6}$ & $\mathbf{2 0 1 7}$ & $\mathbf{2 0 1 8}$ \\
\hline General & 3841 & 3771 & 3881 & 3591 & 3553 \\
\hline Domestic & 3389 & 3295 & 3409 & 3187 & 3196 \\
\hline Street traumas & 331 & 346 & 344 & 338 & 291 \\
\hline Traffic road injuries & 40 & 50 & 57 & 44 & 41 \\
\hline Sports injuries & 13 & 18 & 11 & 13 & 12 \\
\hline Other & 68 & 62 & 60 & 9 & 13 \\
\hline
\end{tabular}

The overall injury rate of the entire population in the Transcarpathian region over the 5 years since 2014 (3841 per 100 thousand population) has decreased by 7,5\%, although it increased in 2016 (3553 per 100 thousand population) (Fig. 2).

Thus, in 2014, the rate of general injury was 3841 per 100 thousand population, in 2015 it decreased by $1,8 \%$ to 3771 per 100 thousand population, and in 2016 it increased by 1\% (3881 per 100 thousand population). In 2017, there was a more significant reduction in the overall injury in the Transcarpathian region by $7,5 \%$ to the level of 3591 per 100 thousand population, while in 2018 it decreased by only 1\% (3553 per 100 thousand population). Also, general traumatism structure for the period of 2014-2018 was studied, the results of the study are presented in Figure 3. This period was characterized by an increase in the share of domestic injuries, a decrease in street and minor fluctuations in road, sports and industrial injuries. 




Fig. 2. Dynamics of the rates of general traumatism in the Transcarpathian region in 2014-2018 (per 100 thousand population)

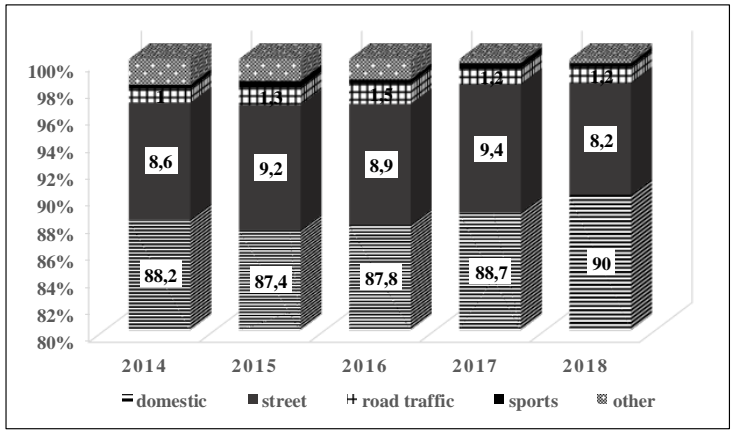

Fig. 3. Structure of traumatism in the Transcarpathian region in 2014-2018 (\%)

At the same time, the largest share in the structure of general traumatism in all years belonged to domestic injury (87.4-90\%) (Fig. 3). This type of injury ranked first among all trauma of the population. The structure of domestic injuries includes wounds, burns, bruises, dislocations, etc. Life in modern conditions is characterized by the excessive amount of various equipment and vehicles in production and households. As a result, people are constantly exposed to dangerous factors during a particular activity. Domestic traumatism combines injuries that occur at home (in the apartment, in the yard). Many injuries occur during quarrels and fights under the influence of alcohol. 
In 2014, domestic injuries in the Transcarpathian region accounted for $88.2 \%$ of the total injury and amounted to 3389 per 100000 population. In 2015, its level increased by 2,6\% to 3295 per 100 thousand population. This represented $87,4 \%$ of the total traumatism in the region. In the following years, there was a gradual decrease in the level of domestic injuries from 3409 per 100000 population in 2016 to 3196 per 100000 population in 2018 (Fig. 4).

At the same time, the share of domestic injuries in the total structure increased from $87.8 \%$ in 2016 to $88,7 \%$ and $90 \%$ in 2017 and 2018, respectively (Fig. 3).

In order to better understand the rates of injuries in Transcarpathian region, it should be noted that the region is characterized by certain geographical peculiarities. Geographically the region can be divided into three landscape zones. The first zone includes 2 mountainous districts (Mizhhiria and Rakhiv), the second - 2 plain areas (Vynohradiv and Berehove), and the third 9 mountain-plain areas (Uzhhorod, Mukachevo, Perechyn, Velykyi Bereznyi, Volovets, Tiachiv and Irshava).

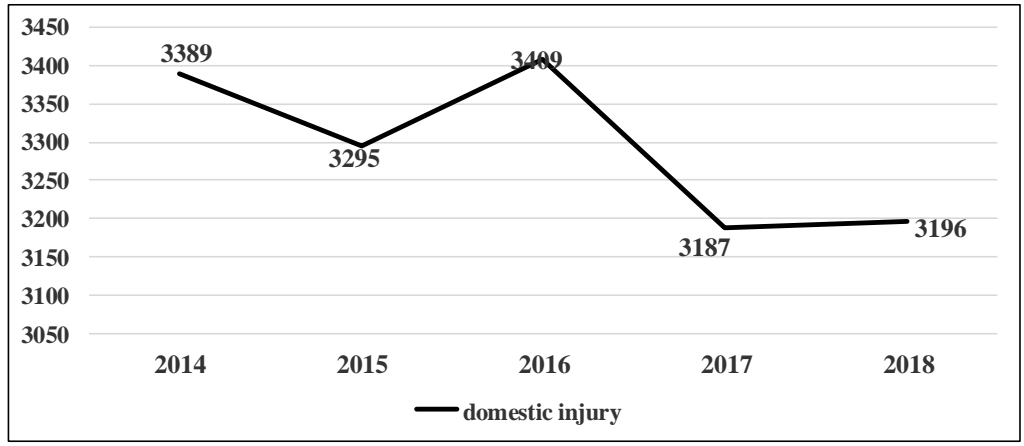

Fig. 4. Dynamics of domestic injury rates in the Transcarpathian region in 2014-2018 (per 100 thousand population)

Particularly noteworthy is Rakhiv district, where the level of domestic injuries, with a tendency to decline over the years of the study, exceeded 5000 per 100 thousand population (5694 in 2014; 5248 in 2015; 5359 in 2016; 5294 in 2017; 5044 in 2018), and also exceeded the national average by 1,5 times. It should be noted that this district is characterized by a significant proportion of the mountain population $(81,9 \%)$. At the same time, such high rates of domestic injuries were not found in other mountainous districts. The lowest level of domestic injuries in all years of the study (2014-2018) was recorded in Uzhgorod district. In five years, it has seen a 
2,2-fold decrease: from 1847 to 825 per 100000 population. This difference is connected with the peculiarities of the registration, since the trauma in Uzhhorod, the regional center is recorded separately and in all years exceeds the regional rate of domestic trauma by 1,3 times.

In order to prevent domestic injuries in the region, measures should be taken to improve living conditions and expand public services to the population, organize leisure and various large-scale cultural and recreational events efficiently, and carry out purposeful work on creating safe domestic environment. All these activities should be carried out with public involvement.

The study of the traumatism in the region has shown that street injury was the next; in 2014-2018 it occupied the second place in the structure of traumatism among the population of the Transcarpathian region $(8,2-9,2 \%)$ (Fig. 3). In 2014, street injuries were reported at the level of 331 per 100 thousand population and accounted for $8,6 \%$ of the total injuries, in 2015 the rate was 346 per 100 thousand population $(9,2 \%)$, in $2016-344$ per 10 thousand population $(8.9 \%)$, in $2017-338$ per 100 thousand population $(9,4 \%)$, and in 2018-291 per 100 thousand population (8,2\%) (Fig. 3, Fig. 5).

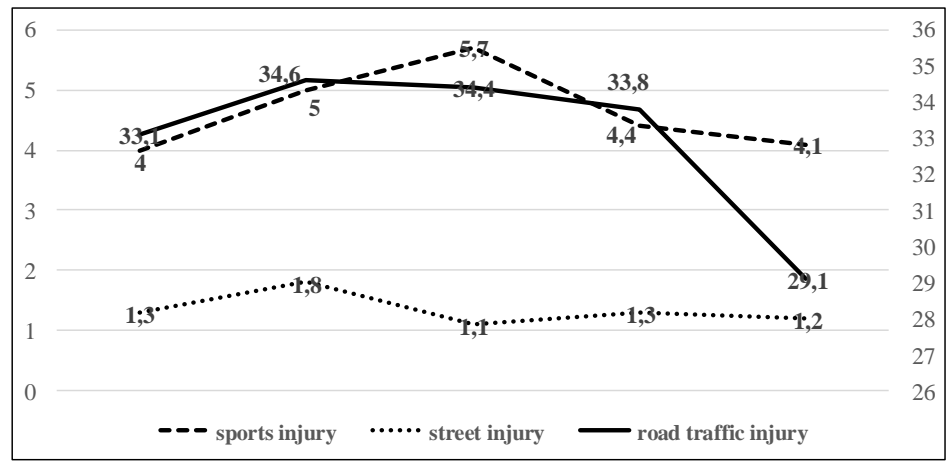

Fig. 5. Dynamics of the rates of street, road traffic and sports injuries in the Transcarpathian region in 2014-2018 (per 10 thousand population)

With a view to preventing street injuries, the authorities raise questions about the rational planning and maintenance of streets and squares with their subsequent proper care and proper lighting. Equally important are the fences of homes under construction or repair, safety of children's leisure, information campaigns for the public (print, radio, television, films, lectures, reports, etc.) on the street safety rules, fight against the use of psychoactive substances, as street injuries often occur to intoxicated persons. 
Road traffic injuries also cause significant damage to public health. Road accidents are caused by different types of vehicles in their movement (traffic) in cases not related to the production activities of the victims, regardless of the victim's presence in the vehicle (driver, passenger) or outside it (pedestrian) at the moment of the accident. A vehicle is any machine used to transport cargo, objects or people (car, motorcycle, bicycle, airplane, steamer, trolleybus, tram, railroad, horse-drawn transport, etc.). Injury in road accidents is caused by a large number of reasons.

The severity of this type of injury is greatly influenced by factors such as the vehicle's speed, the driver's use of psychoactive substances, condition and category of the road, type of settlement, weather conditions, as well as time of the year and time of the day. In Ukraine, the largest number of road accidents is recorded in late summer and autumn months. This is explained by the fact that with relatively high traffic intensity (especially during harvesting campaigns), the weather and climatic conditions, the operational state of the roads (vehicles bringing dirt on the road from unpaved exits, wetting caused by rainfall at the road sides, especially soft shoulders), light and visibility on the road (shortening of daylight hours, fog, rain) become worse. In winter, the accident rate continues to be high, which is caused by poor visibility due to the short duration of the daylight hours, cloudy weather and ice formation on the road surface.

Therefore, road traffic injuries occupy the third place in the structure of general traumatism of the population in the Transcarpathian region (Fig. 3). Within five years its share ranged from $1 \%$ to $1,5 \%$. Since 2014 , there has been an increase in the level of traffic injuries from 40 to 50 and 57 per 100 thousand population in 2015 and 2016 over 3 subsequent years. Instead, in 2017, the number of road injuries in the Transcarpathian region decreased sharply by $29,5 \%$ to 44 per 100 thousand people. And in 2018, the level of this type of injury decreased by another $7 \%$, returned almost to the figure of 2014 and amounted to 41 per 100 thousand population. At the same time, road accidents accounted for $1,2 \%$ of the total injuries in the Transcarpathian region in 2017 and 2018.

It should be noted that the highest level of traffic injuries is characteristic of Mizhhiria district, where $100 \%$ of the villages the status of mountain settlements, and the roadways do not have the status of roads of international importance. Thus, if in 2014 traffic injury rate in the district exceeded the regional by 2,5 times (100 against 40 per 100 thousand population), in 2019 it exceeded the regional rate by 5.3 times ( 219 against 41 per 100 thousand people). The lowest rate of traffic injuries was registered in Mukachevo district. 
In order to prevent road traffic injuries within the framework of public health protection, the «National Action Plan on the Prevention of Noncommunicable Diseases for Achieving Global Sustainable Development Goals» dated 26.07.2018 No. 530-p was adopted by the Cabinet of Ministers of Ukraine ${ }^{8}$. It provides for the preparation and dissemination of information materials to drivers of vehicles and students of driving schools about the effects of driving under the influence of alcohol and drugs; ensuring that traffic safety training materials are included in the training programs for doctors and nurses; involvement of police officers at the local level in training on key behavioral factors; developing and day-to-day involvement of primary care workers; carrying out information campaigns about use of child car seats, developing regulations to increase responsibility for driving in the state of alcohol / drug / toxic substance intoxication.

The above regulatory document also provides for monitoring road safety, which includes:

1) ensuring the establishment of a national road traffic surveillance system, the registration of road accidents, and road traffic deaths and injuries;

2) ensuring the collection of objective and reliable data on gross violations of road safety (speeding, non-use / misuse of seat belts, child seats, helmets, influence of factors distracting from driving);

3 ) ensure the revision of indicators of monitoring road safety violations at the national and regional level for the current assessment of road safety.

The next stage of the study was the analysis of sports injuries. They occur to people involved in sports during exercise or sports competitions. Sports injuries rarely result in death, but they have a significant impact on athletes' health, both immediately after the injury and later. Among all diseases of athletes, almost half account for injuries and traumatic diseases of the musculoskeletal system. The greatest number of sports traumas are due to the influence of physical (mechanical and temperature) factors, and the most common are mechanical ones.

The analysis of the structure of general traumatism in the Transcarpathian region shows that sports traumatism is hardly characteristic of the region, and its share in the structure of general traumatism in 2014,

\footnotetext{
${ }^{8}$ Pro zatverdzhennja Nacionaljnogho planu zakhodiv shhodo neinfekcijnykh zakhvorjuvanj dlja dosjaghnennja ghlobaljnykh cilej stalogho rozvytku [National Action Plan on the Prevention of Noncommunicable Diseases for Achieving Global Sustainable Development Goals]: Rozporjadzhennja Kabinetu Ministriv Ukrajiny [Cabinet of Ministers of Ukraine] 2018, No. 530-p. Retrieved from: https://www.kmu.gov.ua/ua/npas/pro-zatverdzhennyanacionalnogo-planu-zahodiv-shchodo-neinfekcijnih-zahvoryuvan-dlya-dosyagnennyaglobalnih-cilej-stalogo-rozvitku
} 
2016 and 2018 amounted to $0,3 \%$, in 2015 it increased slightly and amounted to $0,5 \%$, and in 2014 to $0,4 \%$.

The analysis of the sports injury has revealed that in 2015 its rate (13 per 100 thousand population) increased by 38,5\% compared to 2014 (18 per 100 thousand population). At the same time, in 2016 it decreased by $39 \%$ up to 11 per 100 thousand population. In 2016 and 2017, the sports injury rates were set as 13 and 12 per 100 thousand residents of the Transcarpathian region.

Particular attention should be paid to occupational injuries. According to the State Labor Service of Ukraine, the absolute values of occupational injuries in Ukraine have decreased by $35 \%$ in the last five-year period of 2014-2018 (6318 cases in 2014, 4126 in 2018). According to the same data, the absolute value of industrial injuries in the Transcarpathian region increased by $16 \%$ (from 44 cases in 2014 to 51 in 2018) ${ }^{9}$. The Transcarpathian region together with some other regions of Ukraine (Chernivtsi, Ternopil, Mykolaiv, Kirovohrad) is characterized by the lowest rate of occupational injuries, with $0,84 \%$ of accidents in $2014-2018^{10}$.

Occupational injury prevention has always been an important part of the measures taken by the government to combat traumatism. Creation of proper working conditions at every workplace, safety and health protection are urgent problems in Ukraine, as there is high morbidity and mortality rate among people of working age, increased levels of occupational and domestic injuries, including ones with lethal consequences. Therefore, in order to prevent occupational injury and to increase the level of production safety, employers, in the first place, should take the following measures: ensure that the safety management system is in place at the enterprise; identify the probability of accidents at work in time and warn employees about the possibility of such situations; eliminate the causes leading to accidents; provide training and assessment of knowledge on the safety of workers, including workers engaged in high-risk work; ensure that employees comply with the requirements of industrial and labor discipline; monitor employees' compliance with the requirements of legislative and regulatory acts on labor protection.

\footnotetext{
${ }^{9}$ State Service of Ukraine on Labor (2019) Statystychni dani vyrobnychogho travmatyzmu z pochatku roku [Statistical data occupational injuries YTD]. Retrieved from: http://dsp.gov.ua/ statystychni-dani-vyrobnychoho-travma-2/

${ }^{10}$ Mitina NB., Babenko O.Ju., Vorobjova L.O., Malynovsjka N.V. (2018) Doslidzhennja stanu travmatyzmu ta rivnja profesijnoji zakhvorjuvanosti na promyslovykh ob'jektakh Ukrajiny [Study of the state of traumatic and professional disease level on industrial objects of Ukraine]. Budivnyctvo, materialoznavstvo, mashynobuduvannja. Zb. nauk. pracj. [Construction, materials science, mechanical engineering], vol. 105, pp.139-147.
} 
The level of injury among children and young people is important in predicting the health of the population, but statistics on its spread in these age groups have not been found. As this category of the population is the future of the country, special attention is paid to the prevention of injuries. This policy is regulated by legislation, in particular the order of the Ministry of Education and Science of Ukraine No. 659 of May 16, 2019 On Approval of the «Regulation on the Procedure of Investigation of Accidents that Occurred with the Students During the Educational Process» ${ }^{11}$. In order to prevent injuries in schools, measures are being taken in accordance with the aforementioned document, which establishes a uniform procedure for investigating and keeping records of accidents that have occurred with pupils, students, cadets, trainees, interns, graduate students, postgraduate students during the educational process, including labor and vocational training in educational institutions, organizations and enterprises in the territory of Ukraine, and extends to institutions of pre-school, general secondary, professional (vocational), extracurricular, specialized education, higher education and institutions of postgraduate education, regardless of ownership and subordination.

Prevention can only be achieved if evidence-based interventions are implemented effectively through systematic and organized approaches. Evidence has systematically been collated in a series of European and world reports on preventing injuries and violence. Sustained investments in safe environments (such as road and housing design) and products (like childproof lighters and packaging for medications), together with the use of legislation, regulation, enforcement and education for behaviour modification and skills development, has allowed many countries in the Region to continue to reduce injury-related deaths.

\section{The value of the S00-T98 category of diseases: Injury, poisoning} and certain other consequences of external causes in the structure

\section{of the general morbidity of the population of the Transcarpathian region}

The dynamics of general morbidity in Ukraine and Transcarpathian region for the period of 2014-2018 have already been considered. For a better understanding of the situation with injuries we have analyzed disease

\footnotetext{
${ }^{11}$ Pro zatverdzhennja Polozhennja pro porjadok rozsliduvannja neshhasnykh vypadkiv, shho stalysja iz zdobuvachamy osvity pid chas osvitnjogho procesu [Regulation on the Procedure of Investigation of Accidents that Occurred with the Students During the Educational Process]: Nakaz Ministerstva osvity i nauky Ukrajiny [Order of the Ministry of Education and Science of Ukraine] 2019, No. 659. Retrieved from: https://zakon.rada.gov.ua/laws/ show/z0612-19
} 
incidence in the category of diseases «Injury, poisoning and certain other consequences of external causes (S00-T98)».

The incidence rate (per 100,000 population) of the category "Injuries, Poisoning and Some Other Consequences of External Causes (S00-T98)" in Ukraine has been more stable in recent years, with changes occurring within 1\%: from 4023 in 2014 to 4010 in 2017 (Fig. 6).

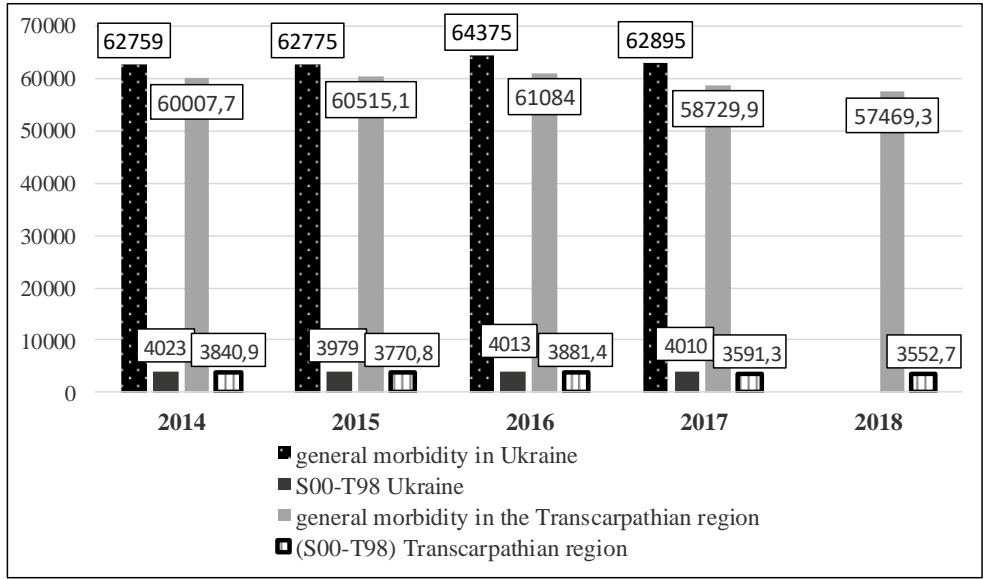

Fig. 6. Total morbidity and morbidity rates by disease of category S00-T98 in Ukraine and Transcarpathian region 2014-2018 (per 100 thousand population)

Although 62759 cases per 100000 population were first reported in Ukraine in 2014, the number of first-time cases identified by the category of «Injury, poisoning and certain other consequences of external causes (S00-T98)» was 6,4\% (4023 per 100 thousand people). It was found that in the Transcarpathian region the share of this category of $(3840,9$ per 100 thousand population) also made $6.4 \%$ in the structure of all first registered diseases in 2014 (60007,7 per 100 thousand population).

It was found that the highest incidence rate for the specified category S00-T98 is characteristic for the mountainous Rakhiv district $(5972,0$ per 100 thousand population), and the lowest for the district Irshava (2134,0 per 100 thousand population).

It was determined that in 2015 , with the total number of first-reported diseases in Ukraine 62775 per 100000 population, the share of the category «Injury, poisoning and certain other consequences of external causes (S00- 
T98)» was 6,3\% (3979 per 100000 people). In the structure of the overall incidence the share of diseases in the above category in the Transcarpathian region $(60515,1$ per 100 thousand population) was $6,2 \%$ and amounted to 3770,8 per 100 thousand population. A detailed analysis showed that in 2015 Rakhiv district also ranked the first in the incidence rate for category S00T98 (5821,2 per 100 thousand population), while in Irshava district the morbidity rate for that category increased 1,2 times (2617,5 per 100 thousand population) and the lowest rate was registered in Uzhhorod district (1255,4 per 100 thousand population).

The chart (Fig. 6) shows an increase in the overall incidence rate in Ukraine in 2016, which amounted to 2,5\% (up to 64375 per 100 thousand population). At the same time, the share of diseases of the category «Injury, poisoning and certain other consequences of external causes (S00-T98)» decreased to $6 . \%$ (4013 per 100 thousand population). In the Transcarpathian region, the overall incidence rate in 2016 also increased by $1 \%$ (61084,6 per 100 thousand population), but the share of the incidence by category S00-T98 (3881,4 per 100 thousand population), unlike in other regions of Ukraine, also increased to $6,4 \%$.

The analysis of morbidity rate made it possible to determine that in 2017 the total number of first registered diseases in Ukraine decreased to 62895 per 100 thousand population, but the share of diseases of the category «Injury, poisoning and certain other consequences of external causes (S00T98)» increased and amounted to 6,4\% (4010 per 100000 population). Instead, in 2017, the share of the above category in the Transcarpathian region decreased to $6.1 \%$ (3591,3 with the overall incidence in the region being 58729,9 per 100 thousand population).

The incidence rate of category S00-T98 (3552,7 per 100 thousand population) in the Transcarpathian region in 2018 decreased by $1,1 \%$, and its share in the structure of the total morbidity across the region ( 57469.3 per 100 thousand population) was $6,2 \%$.

A detailed analysis of the incidence rates of the Transcarpathian region by district revealed that during 2014-2018 the highest rate of morbidity of the category «Injury, poisoning and certain other consequences of external causes (S00-T98)» was recorded in Rakhiv district, except 2018, when the highest rate was registered in Tiachiv district (5460,0 per 100 thousand population).

Thus, the analysis of incidence rates of the category «Injuries, poisoning and some other consequences of external causes (S00-T98)» in the Transcarpathian region has shown a gradual decrease of 7,0\% over 5 years (2014-2018). But in the structure of all reported diseases in the region, the share of this category has remained almost unchanged and amounted to $6,1-6,4 \%$. 
It should be noted that trauma is one of the causes not only of morbidity and mortality, but also of disability of the population. This leads to permanent loss of working capacity of the adult population and, consequently, to production losses, as well as increases social payments, the cost of rehabilitation treatment and maintaining quality of life for the affected population.

Injuries as the cause of disability, ranked third after neoplasms and diseases of the musculoskeletal system in the structure of primary disability in the Transcarpathian region during 2014-2018.

During the period of five years (2014-2018), primary disability was recorded in 16858 persons of working age in the Transcarpathian region; in $10,9 \%$ cases the disability was caused by injuries.

Therefore, a separate analysis has been carried out of the information on primary disability status by adult disability groups in general and injuryrelated disability of the working age population in 2014-2018 based on the statistics of the Medical Social Expert Commission of the Transcarpathian region (Table 2).

Obviously, Group III (63-73\%) accounted for the majority of injuryrelated disabilities among disability groups for persons of working age. At the same time, $8,4 \%$ of all persons of working age who applied for disability status due to traumas have received Group I disability status in 5 years.

The analysis has shown that the share of the third disability group among persons of working age with primary injury-related disability within five years increased from $69,2 \%$ to $73,1 \%$. But the fact that the share of Group I decreased from $7,1 \%$ to $5,9 \%$ (Table 2) is positive.

In the structure of primary injury-related disability of persons of working age the share of Group II for the period of 2014-2018 took an average position and was $30,6 \%$ in 2017. In 2018 this figure dropped to $21,2 \%$.

All this highlights the importance of prevention of traumas and injury in general within the policy of preserving the working capacity of the region's population. 
Table 2

Primary injury-related disability of the population of the Transcarpathian region in 2014-2018

\begin{tabular}{|c|c|c|c|c|c|c|c|c|c|c|c|c|c|c|}
\hline \multirow{3}{*}{ Years } & \multicolumn{7}{|c|}{ Total population } & \multicolumn{7}{|c|}{ Working-age population } \\
\hline & \multirow{2}{*}{$\frac{\stackrel{\pi}{\frac{\pi}{6}}}{\stackrel{\dot{\theta}}{\sigma}}$} & \multicolumn{2}{|c|}{ 预 } & \multicolumn{2}{|c|}{ 总 } & \multicolumn{2}{|c|}{ 总是 } & \multirow{2}{*}{$\frac{\stackrel{\tilde{\pi}}{0}}{\dot{\theta}}$} & \multicolumn{2}{|c|}{ 莺 } & \multicolumn{2}{|c|}{ 总 } & \multicolumn{2}{|c|}{ 总是 } \\
\hline & & 完 & o & $\begin{array}{l}\dot{\sigma} \\
\frac{\sigma}{\sigma}\end{array}$ & $s^{\circ}$ & $\frac{\dot{\theta}}{\sigma}$ & $0^{\circ}$ & & 完 & $0^{\circ}$ & 完 & $\therefore$ & 完 & $\therefore$ \\
\hline ָั & $\tilde{y}$ & ले & a & 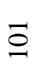 & ते & $\widetilde{\sim}$ & बें & \&̊+ & ते & $\vec{\therefore}$ & ஃ & $\ddot{\lambda}$ & $\vec{\sim}$ & ถู \\
\hline กิ่ & $\stackrel{\bigcirc}{\ni}$ & m & $\infty_{\infty}^{m}$ & $\infty$ & $\frac{n}{i}$ & $\stackrel{\infty}{\sim}$ & $\stackrel{1}{2}$ & $\infty$ & तิ & in & $\infty$ & $\stackrel{0}{\vec{N}}$ &  & $\hat{i}$ \\
\hline ํํำ & $\underset{n}{ \pm}$ & $\bar{\imath}$ & 2 & 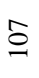 & $\begin{array}{l}0 \\
\text { Dे } \\
\text { in }\end{array}$ & $\stackrel{9}{\sim}$ & $\begin{array}{l}\text { r } \\
\text { t }\end{array}$ & 管 & $\beth$ & $\vec{f}$ & $\stackrel{\infty}{\sigma}$ & 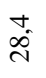 & તે & $\widehat{8}$ \\
\hline ลิ & $\bar{m}$ & $m$ & $a$ & gे & $\overrightarrow{\hat{\lambda}}$ & $\underset{\text { I }}{\text { S }}$ & है & in & ิ & $\tilde{n}$ & $\subseteq$ & : & & $\overline{8}$ \\
\hline 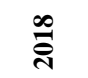 & ช̂? & $m$ & $\infty_{\infty}^{2}$ & $\infty$ & ¿ें & $\stackrel{\substack{i \\
i}}{i}$ & 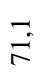 & $\stackrel{n}{m}$ & तิ & in & $\because$ & $\frac{N}{\pi}$ & $\stackrel{\infty}{\sim}$ & $\vec{\Re}$ \\
\hline 吾 & 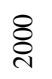 & $\stackrel{\infty}{\circ}$ & ${ }_{\infty}^{+}$ & $\begin{array}{l}\infty \\
\infty \\
+\end{array}$ & $\dot{d}$ & $\stackrel{7}{2}$ & $\frac{2}{8}$ & ले & $\stackrel{\infty}{=}$ & के & भे & & $\stackrel{\mathbb{I}}{\stackrel{I}{2}}$ & ถู \\
\hline
\end{tabular}

\section{CONCLUSIONS}

Traumatism has significant medical and social importance for the state and each of its regions, since its spread affects the mortality rate, causes significant economic losses in production, leads to increased costs of medical care, rehabilitation treatment and maintaining the quality of life of individuals.

Systematic analysis shows that over the last five years (2014-2018) the incidence rate (per 100000 population) of the category of diseases «Injury, poisoning and certain other consequences of external causes (S00-T98)» in Ukraine has decreased by 1\%: from 4023 in 2014 to 4010 in 2017. In the Transcarpathian region the incidence rate for the specified category has decreased gradually by $7 \%$ during 2014-2018: from 3840,9 to 3552,7 per 100 thousand population. However, in the structure of all reported diseases 
in the region, the share of S00-T98 diseases has remained almost unchanged, accounting for $6,1-6,4 \%$.

It has been found that the overall rate of injuries in the Transcarpathian region has decreased by $7,5 \%$ over 5 years since 2014 . This period has been characterized by an increase in the share of domestic injuries, a decrease in street and minor fluctuations in road, sports and occupational injuries. In general, the rates of all types of injuries have reduced across the Transcarpathian region.

The analysis of the structure of primary disability in the Transcarpathian region during 2014-2018 has shown that injuries as a cause of disability ranked third after neoplasms and diseases of the musculoskeletal system.

Despite some positive dynamics, the traumatism situation requires consolidated efforts by society towards the prevention of the spread of trauma through cross-sectoral interaction at the state and regional levels. The specific features of each region should be taken into account in developing injury prevention and trauma care measures.

\section{SUMMARY}

Traumatism has significant medical and social importance for the state and each of its regions, since its spread affects the mortality rate, causes significant economic losses in production, leads to increased costs of medical care, rehabilitation treatment and maintaining the quality of life of individuals with disabilities.

Special attention has been given to the westernmost region of Ukraine, the Transcarpathian region, which is characterized by certain features: the predominance of rural population (63\%), borderline placement (with 4 other countries), a large number of villages with the status of mountain settlements, recurrent natural disasters such as floods, massive migration to other regions of Ukraine and abroad, and so on. In order to plan injury prevention measures in the Transcarpathian region, the dynamics and state of the spread of various types of injuries in the region in 2014-2018 have been analyzed. Systematic analysis has shown that the overall rates of injuries in the Transcarpathian region has decreased by 7,5\% over 5 years since 2014. This period has been characterized by an increase in the share of domestic injuries, a decrease in street and minor fluctuations in road, sports and occupational injuries. In general, there is a tendency for all types of injuries in the Transcarpathian region to decrease.

Despite some positive dynamics, the traumatism situation requires consolidated efforts by society towards the prevention of the spread of trauma through cross-sectoral interaction at the state and regional levels. The 
specific features of each region should be taken into account in developing injury prevention and trauma care measures.

\section{REFERENCES}

1. Sethi D, Mitis F, Racioppi F. (2010). Preventing injuries in Europe: from international collaboration to local implementation. Copenhagen: WHO Regional Office for Europe. Retrieved from: http://www.euro.who.int/en/publications/ abstracts/preventing-injuries-ineurope-from-international-collaboration-to-localimplementation.

2. Aldridge E, Sethi D. Yon Y. (2017). Injuries: a call for public health action in Europe. Copenhagen: WHO Regional Office for Europe. Retrieved from: http://www.euro.who.int/_data/assets/pdf_file/0018/348102/ WH08_IJ_complete-web-version.pdf?ua=1

3. Derzhavna sluzhba statystyky Ukrainy (2017) Zaklady okhorony zdorov'ja ta zakhvorjuvanistj naselennja Ukrajiny u 2016 roci [Healthcare institutions and the incidence of the population of Ukraine in 2016], Kyiv. Retrieved from: http://www.ukrstat.gov.ua/druk/publicat/kat_u/2016/bl/06/bl_zoz_15xl.zip

4. Derzhavna sluzhba statystyky Ukrainy (2018) Zaklady okhorony zdorov'ja ta zakhvorjuvanistj naselennja Ukrajiny u 2017 roci [Healthcare institutions and the incidence of the population of Ukraine in 2017], Kyiv. Retrieved from: http://www.ukrstat.gov.ua/druk/publicat/kat_u/2018/ zb/06/zb_zoz_17.pdf

5. Dmytrjuk S. P., Ghodjajev S. Gh. (2017). Osnovni prychyny ta metody analizu pokaznykiv vyrobnychogho travmatyzmu [Principal reasons and methods of analysis of indexes of production traumatism of]. Budivnyctvo, materialoznavstvo, mashynobuduvannja. Z Zb. nauk. pracj [Construction, materials science, mechanical engineering], vol. 101, pp.94-99.

6. Lazebnyk Ju. O. (2018). Proghramno-metodologhichni zasady udoskonalennja nacionaljnoji systemy sposterezhennja zi statystyky travmatyzmu [Program-methodological Principles of Improvement of the National System of Statistical Observation of Traumatism]. Statistics of the Ukraine, no. 3, pp. 49-58.

7. Barannyk L. B. (2019) Zdorov'ja naselennja jak indykator rozvytku socialjnogho kapitalu v Ukrajini [Public health as an indicator of the social capital development in Ukraine]. Scientific Notes of Ostroh Academy National University, «Economics» series, no. 12, pp. 64-69. Retrieved from: http://nbuv.gov.ua/UJRN/Nznuoa_2019_12_12.

8. Pro zatverdzhennja Nacionaljnogho planu zakhodiv shhodo neinfekcijnykh zakhvorjuvanj dlja dosjaghnennja ghlobaljnykh cilej stalogho 
rozvytku [National Action Plan on the Prevention of Noncommunicable Diseases for Achieving Global Sustainable Development Goals]: Rozporjadzhennja Kabinetu Ministriv Ukrajiny [Cabinet of Ministers of Ukraine] 2018, No. 530-p. Retrieved from: https://www.kmu.gov.ua/ua/ npas/pro-zatverdzhennya-nacionalnogo-planu-zahodiv-shchodoneinfekcijnih-zahvoryuvan-dlya-dosyagnennya-globalnih-cilej-stalogorozvitku

9. State Service of Ukraine on Labor (2019) Statystychni dani vyrobnychogho travmatyzmu z pochatku roku [Statistical data occupational injuries YTD]. Retrieved from: http://dsp.gov.ua/statystychni-danivyrobnychoho-travma-2/

10. Mitina NB., Babenko O.Ju., Vorobjova L.O., Malynovsjka N.V. (2018) Doslidzhennja stanu travmatyzmu ta rivnja profesijnoji zakhvorjuvanosti na promyslovykh ob'jektakh Ukrajiny [Study of the state of traumatic and professional disease level on industrial objects of Ukraine]. Budivnyctvo, materialoznavstvo, mashynobuduvannja. Z $b$. nauk. pracj [Construction, materials science, mechanical engineering], vol. 105, pp.139-147.

11. Pro zatverdzhennja Polozhennja pro porjadok rozsliduvannja neshhasnykh vypadkiv, shho stalysja iz zdobuvachamy osvity pid chas osvitnjogho procesu [Regulation on the Procedure of Investigation of Accidents that Occurred with the Students During the Educational Process]: Nakaz Ministerstva osvity i nauky Ukrajiny [Order of the Ministry of Education and Science of Ukraine] 2019, No. 659. Retrieved from: https://zakon.rada.gov.ua/laws/show/z0612-19

\section{Information about the author:} Brych V. V., orcid.org/0000-0003-3741-6002 Associate Professor at the Department of Health Sciences Uzhhorod National University 29, Mytna str., 88000, Uzhhorod, Ukraine 
DOI https://doi.org/10.36059/978-966-397-155-1/62-79

\title{
CHARACTERISTICS OF THE NETWORK OF HEALTH CARE INSTITUTIONS AND PERSONNEL OF THE TRANSCARPATHIAN REGIONAL HEALTH CARE SYSTEM
}

\author{
Danko D. V.
}

\section{INTRODUCTION}

The main strategic goals of the health care system are preserving and improving the health of the population, enhancing the quality of medical care, as well as developing specific medical preventive measures, forms and methods of work of specialized services. The attainment of these goals is impossible without developing effective health care institutions network and providing skilled personnel. To make sound management decisions at all levels, including the regional level, it is necessary to conduct a thorough analysis of both the availability and use of all health care resources, including the network of institutions and the supply of qualified medical personnel.

In the current conditions, consistent work is being done to optimize and further develop the network of health care facilities delivering all types of medical care within the health care system of Ukraine ${ }^{1}$.

This is facilitated by the existence of a comprehensive health care system in the country that has been operating for about ten years, and its activities have been refined in pilot regions ${ }^{2}{ }^{3}$.

At present the reform of the health care system in Ukraine involves restructuring of the system with the priority of the development of primary

\footnotetext{
${ }^{1}$ Stratehichna doradcha hrupa z pytan reformuvannia systemy okhorony zdorovia v Ukraini (2015) Natsionalna stratehiia reformuvannia systemy okhorony zdorovia v Ukraini na period 2015-2020 rokiv [National Health Care Reform Strategy in Ukraine for the period of 20152020], pp. 41. Retrived from: http://healthsag.org.ua/strategiya/

${ }^{2}$ Lekhan V.M., Slabkyi H.O., Shevchenko M.V. (2015) Analiz rezultativ reformuvannia systemy okhorony zdorovia $\mathrm{v}$ pilotnykh rehionakh: pozytyvni naslidky, problemy ta mozhlyvi shliakhy yikh vyrishennia [Analyzing health reform outcomes in pilot regions: positive impacts, challenges, and possible solutions]. Zdorovia natsii, vol. 3 (Special issue), pp. 67-86.

3 Slabkyi H.O., Lekhan V.M. (2015) Uroky reformy okhorony zdorovia v Ukraini: dosiahnennia, nevyrisheni pytannia, ryzyky, problemy [Healthcare reform lessons in Ukraine: achievements, unresolved issues, risks, challenges]. Proceedings of the International Conference "Orhanizatsiia i upravlinnia okhoronoiu zdorovia" (Ukraine, October 20-21, 2015), pp. 26-27.
} 
medical health care based on general practice/family medicine (primary (care) ${ }^{4}$, in which there is the benefit of free choice of family doctors on the one hand ${ }^{5}$ and family doctors determine the patients' clinical pathways on the other ${ }^{6}$. At the level of specialized medical care Formation of hospital districts with the formation of intensive care hospitals is envisaged ${ }^{7}$. Also, a qualitatively new medical professional training system with continuous professional development will be introduced ${ }^{8}$.

Fundamentally new to the healthcare system of Ukraine is the introduction of a guaranteed package of medical services on the principle of «money follows the patient ${ }^{9}$, as well as the autonomy of healthcare institutions ${ }^{10}$.

The reform process is implemented step by step and allows to improve different elements and levels of health care work and medical care technologies, to introduce new organizational forms and accumulate the necessary resources.

${ }^{4}$ Slabkyi H. O., Zozulia I.S., Zozulia A.I. (2014) Priorytetnyi rozvytok pervynnoi medykosanitarnoi dopomohy na zasadakh simeinoi medytsyny [Priority development of primary health care based on family medicine]. Simeina medytsyna, vol. 3, No. 53, pp. 25-27.

5 Lekhan V. M., Nadutyi K.O., Slabkyi H.O. (2011) Innovatsiini pidkhody do zabezpechennia dostupnosti pervynnoi medyko-sanitarnoi dopomohy silskomu naselenniu [Innovative approaches to ensuring the availability of primary health care to the rural population]. Zdorovia natsii, vol. 3, No. 19, pp. 86-91.

${ }^{6}$ Matiukha L.F., Lekhan V.M., Hoida N.H. et al. (2011) Poriadok orhanizatsii nadannia medychnoi dopomohy ta zabezpechennia marshrutiv patsiienta likarem zahalnoi praktyky simeinym likarem pry riznykh klinichnykh stanakh ta zakhvoriuvanniakh [The procedure for the organization of care and providing pathways by a general practitioner - family physician in different clinical conditions and diseases]. Ministry of Health of Ukraine; National Medical Academy of Post-Graduate Education named after P. L. Shupyk, Ukrainian Institute for Social Research, Dnipropetrovsk State Medical Academy, Zaporizzhia Medical Post-Graduate Academy, Chernivtsi Health Care Department, p. 43.

${ }^{7}$ Parkhomenko H. Ya. (2011) Likarnia intensyvnoi dopomohy - likarnia yevropeiskoho zrazka [Intensive care hospital - a European-style hospital]. Visnyk sotsialnoi hihiieny ta orhanizatsii okhorony zdorovia Ukrainy, vol. 2, pp. 39-41.

${ }^{8}$ Kotenko S.L. (2015) Derzhavne rehuliuvannia kadrovoi polityky haluzi okhorony zdorovia [State regulation of the personnel policy of the health care industry]. Proceedings of the naukovo- Proceedings of the Conference "Zavdannia derzhavy u zabezpechenni efektyvnoi kadrovoi polityky systemy okhorony zdorovia" (Ukraine, Kyiv, April 22, 2015), pp. 56-59.

${ }^{9}$ Zakon Ukrainy vid 19 zhovtnia 2017 roku 2168-VIII (2017) Pro derzhavni finansovi harantii medychnoho obsluhovuvannia naselennia [Law of Ukraine On State Financial Guarantees of Public Health Services: Law of Ukraine of October 19, 2017 No. 2168-VIII]. Retrieved from: http://search.ligazakon.ua/l_doc2.nsf/link1/T172168.html

${ }^{10}$ Skryp V. V., Slabkyi H.O. (2015) Metodychni pidkhody do avtonomizatsii zakladiv okhorony zdorovia [Methodological approaches to the autonomy of health care institutions]. Intermedical Journal, vol. IV, No. 6, pp. 20-25. 
In this regard, there is a need for further improvement of the health care system organization and management. It is necessary to promote the optimization and restructuring of health care institutions network, prioritize the development of the primary care based on general practice/family medicine and emergency medical care, the formation of rehabilitation and palliative care facilities network, and the introduction of modern medical technologies of prevention, diagnostics, treatment, and rehabilitation.

In the context of the priority of primary care development and preparation for specialized and highly specialized medical care reform, it was found expedient to study and conduct a comprehensive system analysis of providing medical care to the population of the Transcarpathian region of Ukraine. It is a mountainous region, in which population is distributed according to the following geographical areas: flatland, foothill and mountainous zones ${ }^{11}$.

\section{Characteristics of health care institutions network in the Transcarpathian region}

The analysis of the network of the health care institutions in the Transcarpathian region was conducted using data from the Department of Health of the Transcarpathian Regional State Administration for the period of $2014-2018^{12}$. $^{13}$

The initial phase of the study included the analysis of the overall network of health care institutions/ separate subdivisions of the Transcarpathian region, with the population numbers in the administrative territories as of the end of 2018 (Table 1), followed by its comparison with 2014 and 2017 data.

11 Rohach I.M., Danko D.V. (2019) Kharakterystyka naselennia Zakarpatskoi oblasti [Characteristics of the population of the Transcarpathian region]. Ekonomika i pravo okhorony zdorovia, vol. 1, No. 9, pp. 75-78.

12 Zakarpatskyi oblasnyi medychnyi informatsiino-analitychnyi tsentr (2015) Merezha zakladiv ta osnovni pokaznyky diialnosti systemy okhorony zdorovia Zakarpatskoi oblasti za 2014 rik.[Network of institutions and key indicators of health care system activity in Transcarpathian region for 2014] Uzhhorod: Zakarpatskyi oblasnyi medychnyi informatsiinoanalitychnyi tsentr.

${ }^{13}$ Zakarpatskyi oblasnyi medychnyi informatsiino-analitychnyi tsentr (2019) Merezha zakladiv ta osnovni pokaznyky diialnosti systemy okhorony zdorovia Zakarpatskoi oblasti za 2018 rik [The network of institutions and key indicators of the health care system of Transcarpathian region for 2018] Uzhhorod: Zakarpatskyi oblasnyi medychnyi informatsiinoanalitychnyi tsentr. 
Table 1

General network of health care institutions/subdivisions of the Transcarpathian region with the number of population in administrative territories, 2018

\begin{tabular}{|c|c|c|c|c|c|c|c|c|c|c|c|c|c|c|}
\hline $\begin{array}{c}\text { Adminis- } \\
\text { trative } \\
\text { territories }\end{array}$ & 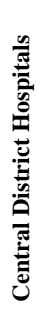 & 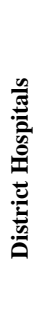 & 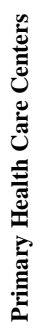 & 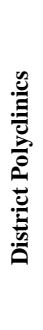 & 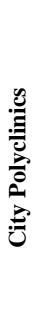 & 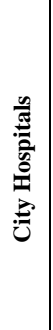 & 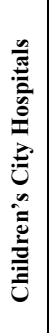 & 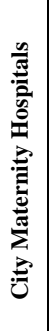 & 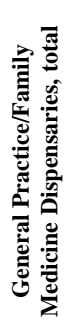 & 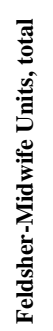 & 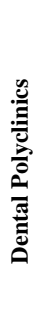 & 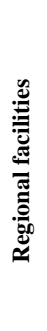 & 吾 & 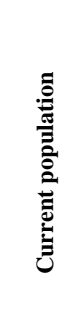 \\
\hline \multicolumn{15}{|c|}{ Districts } \\
\hline $\begin{array}{c}\text { Berehove } \\
\text { district }\end{array}$ & 1 & - & 1 & - & - & - & - & - & 24 & 19 & - & - & 45 & 74949 \\
\hline $\begin{array}{c}\text { VelykyiBer } \\
\text { eznyi } \\
\text { district }\end{array}$ & - & 1 & 1 & - & - & - & - & - & 9 & 24 & - & - & 365 & 26414 \\
\hline $\begin{array}{c}\text { Vynohradiv } \\
\text { district }\end{array}$ & - & 1 & 1 & - & - & - & - & - & 35 & 16 & - & - & 53 & 121187 \\
\hline $\begin{array}{l}\text { Volovets } \\
\text { district }\end{array}$ & 1 & - & 1 & - & - & - & - & - & 5 & 23 & - & - & 30 & 24175 \\
\hline $\begin{array}{l}\text { Irshava } \\
\text { district }\end{array}$ & - & 1 & 1 & - & - & - & - & - & 33 & 11 & 1 & - & 47 & 100493 \\
\hline $\begin{array}{c}\text { Mizhhiria } \\
\text { district }\end{array}$ & - & 1 & 1 & - & - & - & - & - & 17 & 20 & - & - & 39 & 47715 \\
\hline $\begin{array}{c}\text { Mukachevo } \\
\text { district }\end{array}$ & 1 & - & 2 & - & - & - & - & - & 36 & 45 & - & - & 84 & 186352 \\
\hline $\begin{array}{c}\text { Perechyn } \\
\text { district }\end{array}$ & 1 & - & 2 & - & - & - & - & - & 9 & 13 & - & - & 25 & 31936 \\
\hline $\begin{array}{l}\text { Rakhiv } \\
\text { district }\end{array}$ & - & 1 & 1 & - & - & 2 & - & - & 25 & 8 & - & - & 37 & 92814 \\
\hline $\begin{array}{c}\text { Svaliava } \\
\text { district }\end{array}$ & 1 & & 2 & - & - & & - & - & 14 & 11 & - & - & 28 & 54628 \\
\hline $\begin{array}{l}\text { Tiachiv } \\
\text { district }\end{array}$ & - & 2 & 3 & 1 & - & 2 & - & - & 36 & 25 & 1 & - & 74 & 175478 \\
\hline $\begin{array}{c}\text { Uzhhorod } \\
\text { district }\end{array}$ & - & 1 & 2 & - & - & - & - & - & 28 & 29 & - & - & 60 & 71635 \\
\hline $\begin{array}{c}\text { Khust } \\
\text { district }\end{array}$ & - & 1 & 1 & 1 & - & - & - & - & 27 & 16 & 1 & - & 47 & 127434 \\
\hline \multicolumn{15}{|c|}{ Cities } \\
\hline Uzhhorod & - & - & 1 & - & 1 & 1 & 1 & 1 & 9 & - & - & - & 14 & 113996 \\
\hline Chop & - & - & 1 & - & - & 1 & - & - & 1 & - & - & - & 3 & 8949 \\
\hline Additional & - & - & - & - & - & - & - & - & - & - & - & 25 & 25 & - \\
\hline Total & 5 & 9 & 21 & 2 & 1 & 6 & 1 & 1 & 308 & 260 & 3 & 25 & 646 & 1258155 \\
\hline
\end{tabular}


The analysis of the data presented in Table 1 indicates that the Transcarpathian region has an extensive network of health care institutions and separate structural units of primary, specialized and highly specialized medical care. In addition to the health facilities listed in the table, there are 4 community hospitals in Tiachiv district. In total there are 646 health facilities and their separate subdivisions in the region. $91.18 \%$ of health care institutions /separate units provide primary health care, $4,95 \%$ specialized health care, and $3.87 \%$ highly specialized medical care. However, the number of health care institutions in the region's administrative territories and the number of the population living in these territories do not correlate.

The number of health care institutions and their separate structural divisions has increased by 16 compared with 2014. However, it has decreased by 5 compared with 2017. The largest structural changes in the health care institutions network have occurred due to an increase in the number of General Practice/Family Medicine Dispensaries (GPFMD) by 33 and a decrease in the number of Feldsher-Midwife Units (FMU) by 20 in comparison with 2014.

The network of institutions/separate structural divisions of primary health care was analyzed in detail according to the region's geographical zones. There are the following geographical zones in the region: flatlands, foothill areas and mountain areas. The data obtained are shown in Table. 2.

The analysis of the data presented in Table 2 indicates that the regional primary health care system was fully formed in 2018. Its facilities are legally delimited with specialized health care facilities regardless of the region's geographical zones. For this purpose, Primary Health Care Centers (PHCC), which included GPFMD and FMU were established in all administrative territories. The total number of GPFMD is 308, out of these 48 GPFMD $(15.58 \%)$ operate in cities and $260(84.42 \%)$ in rural areas. The total number of FMU is $260.38(14.62 \%)$ of them are located in villages with the population of more than 1000 people.

In accordance with the current regulations, GPFMD should be formed and general practice/family medicine (GP/FM) positions should be introduced in health care units in these administrative territories.

The number of GPFMD correlates with the population numbers in all administrative territories, except for the city of Uzhhorod.

The number of PHCC increased by 10 in comparison with 2014. The new centers include 6 that were established in the newly formed territorial communities. The number of GPFMD increased by 33. All the independent primary health care structural units and the ones that were part of the specialized health care institutions are included in the PHCC. 
Table 2

Network of health care institutions / separate units of primary health care of the Transcarpathian region in the context of administrative territories and geographical zones, 2018

\begin{tabular}{|c|c|c|c|c|c|c|c|}
\hline $\begin{array}{c}\text { Administrative } \\
\text { territories, } \\
\text { geographical zones }\end{array}$ & $\begin{array}{c}\text { Primary } \\
\text { Health } \\
\text { Care } \\
\text { Centers }\end{array}$ & $\begin{array}{c}\text { General } \\
\text { Practice/ } \\
\text { Family } \\
\text { Medicine } \\
\text { Dispen- } \\
\text { saries }\end{array}$ & $\begin{array}{c}\text { General Practice/ } \\
\text { Family Medicine } \\
\text { Dispensaries }\end{array}$ & $\begin{array}{c}\text { Felds } \\
\text { her- } \\
\text { Mid } \\
\text { wife }\end{array}$ & $\begin{array}{c}\text { Feldsher- } \\
\text { Midwife } \\
\text { Units in } \\
\text { villages } \\
\text { with the } \\
\text { population } \\
\text { over 1000 }\end{array}$ \\
\hline \multicolumn{7}{|l|}{ Flatland zone } \\
Units
\end{tabular}

The next step in the study was to examine the health care facilities network in the Transcarpathian region according to geographical zones and analyze it in comparison with 2014. The data obtained are shown in table 3.

According to the data in table 3 , there are specialized medical care facilities in each administrative territory in the region that provide both outpatient and inpatient medical care; however, they differ structurally. Thus, there are central district hospitals $(\mathrm{CDH})$ in five districts, district hospitals $(\mathrm{DH})$ in nine districts, city hospitals $(\mathrm{CH})$ in two districts, district polyclinics in two districts and dental polyclinics in three districts. It should be noted that there are two city hospitals in both Tiachiv and Rakhiv districts respectively. Also, there are four community hospitals in Tiachiv district, while Children's Hospital, which provides specialized medical care, operates only in Uzhhorod. 


\section{Table 3}

\section{Network of Health Care Institutions that Provide Specialized Medical Assistance in Transcarpathian Region in the context of Administrative Territories and Geographical Zones, 2018}

\begin{tabular}{|c|c|c|c|c|c|c|c|c|}
\hline $\begin{array}{l}\text { Administrative } \\
\text { territories, } \\
\text { geographical zones }\end{array}$ & ชิ & $\overline{\mathbf{D}}$ & 苞 & 色 & 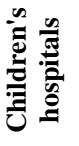 & 离品 & 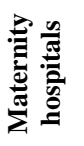 & 焉 \\
\hline \multicolumn{9}{|c|}{ Flatland zone } \\
\hline Uzhhorod city & - & - & 1 & 1 & 1 & - & 1 & - \\
\hline Chop city & - & - & 1 & - & - & - & - & - \\
\hline Berehove district & 1 & - & - & - & - & - & - & - \\
\hline Vynohradiv district & & 1 & - & - & - & - & - & - \\
\hline Mukachevo district & 1 & - & - & - & - & - & - & - \\
\hline Uzhhorod district & $\alpha$ & 1 & - & - & - & - & - & - \\
\hline \multicolumn{9}{|c|}{ Foothill zone } \\
\hline Irshava district & - & 1 & - & - & - & - & - & 1 \\
\hline Perechyn district & 1 & - & - & - & - & - & - & - \\
\hline Svaliava district & 1 & - & - & - & - & - & - & - \\
\hline Tiachiv district & - & 2 & 2 & 1 & - & 4 & - & 1 \\
\hline Khust district & - & 1 & & 1 & - & - & - & 1 \\
\hline \multicolumn{9}{|c|}{ Mountain zone } \\
\hline $\begin{array}{l}\text { VelykyiBereznyi } \\
\text { district }\end{array}$ & - & 1 & - & - & - & - & - & - \\
\hline Volovets district & 1 & - & - & - & - & - & - & - \\
\hline Mizhhiria district & - & 1 & & - & - & - & - & - \\
\hline Rakhiv district & - & 1 & 2 & - & - & - & - & - \\
\hline
\end{tabular}

The following health care facilities, which provided specialized medical care were closed in the region in the period of 2014-2018: Uzhhorod District Hospital, Uzhhorod District Polyclinic and five district hospitals (three in Mukachevo district and two in Rakhiv district). During the same period, District Dental Polyclinic was opened in Tiachiv.

Outpatient care has the largest demand of all specialized medical care. Therefore, the next step of the study was to examine the planned capacity of outpatient polyclinics in terms across the region's administrative territories and geographical zones in the dynamics of 2014 and 2018. The data obtained are shown in Table. 4. 
Table 4

Planned capacity of outpatient polyclinics for specialized health care delivery in the context of administrative territories and geographical zones, 2014, 2018 (per 10,000 population)

\begin{tabular}{|c|c|c|c|}
\hline $\begin{array}{c}\text { Administrative territories, } \\
\text { geographical zones }\end{array}$ & $\mathbf{2 0 1 4}$ & $\mathbf{2 0 1 8}$ & $\mathbf{2 0 1 8}$ to 2014 \\
\hline \multicolumn{5}{|c|}{ Flatland zone } \\
\hline Uzhhorod city & 179 & 176 & -3 \\
\hline Berehove district & 194 & 190 & -4 \\
\hline Vynohradiv district & 192 & 184 & -8 \\
\hline Mukachevo district & 181 & 175 & -6 \\
\hline Uzhhorod district & 207 & 196 & \\
\hline \multicolumn{5}{|c|}{ Foothill zone } \\
\hline Irshava district & 248 & 244 & +17 \\
\hline Perechyn district & 211 & 228 & - \\
\hline Svaliava district & 157 & 157 & +1 \\
\hline Tiachiv district & 196 & 197 & +2 \\
\hline Khust district & 134 & 136 & -1 \\
\hline \multicolumn{5}{|c|}{ Mountain zone } \\
\hline VelykyiBereznyi district & 259 & 258 & -1 \\
\hline Volovets district & 197 & 196 & -2 \\
\hline Mizhhiria district & 196 & 194 & +2 \\
\hline Rakhiv district & 209 & 211 & \\
\hline
\end{tabular}

The analysis of the data presented in Table 4 indicates that there were no statistically significant differences in all administrative territories of the region in terms of planned outpatient clinics capacity for specialized medical care delivery in the period of 2014-2018.There is also no correlation between the geographical zone and the planned capacity for specialized medical care delivery of the outpatient clinics that function in that specific zone. At the same time, statistically significant differences were established in the planned outpatient clinics capacity for specialized medical care provision in different administrative territories. In Uzhhorod, the planned outpatient clinics capacity to provide specialized health care per 10,000 populations is 176 receptions per day. In terms of districts, the marginal difference of this rate is 1.90 times and ranges from 136 receptions in Khust district (foothill zone) to 258 in Velykyi Bereznyi district (mountain zone). This situation shows unequal access of the population from different administrative territories of the region to specialized outpatient care.

Further, the availability of hospital beds for the provision of specialized medical care was examined in the context of administrative territories and 
geographical zones. Comparisons were made between the availability of beds for specialized care in 2014 and 2018. The data obtained are shown in table 5.

Table 5

\section{Availability of hospital beds for specialized medical care in the context of administrative territories and geographical zones, 2014, 2018 (per 10,000 population)}

\begin{tabular}{|c|c|c|c|}
\hline $\begin{array}{c}\text { Administrative territories, } \\
\text { geographical zones }\end{array}$ & $\mathbf{2 0 1 4}$ & $\mathbf{2 0 1 8}$ & $\mathbf{2 0 1 8}$ to 2014 \\
\hline \multicolumn{5}{|c|}{ Flatland zone } \\
\hline Uzhhorod city & 54,55 & 55,50 & $+0,95$ \\
\hline Berehove district & 44,72 & 38,82 & $-5,90$ \\
\hline Vynohradiv district & 41,53 & 39,58 & $-1,95$ \\
\hline Mukachevo district & 45,45 & 28,23 & $-17,22$ \\
\hline Uzhhorod district & 18,65 & 38,45 & $+19,80$ \\
\hline \multicolumn{5}{|c|}{ Foothill zones } \\
\hline Irshava district & 40,64 & 39,76 & $-0,88$ \\
\hline Perechyn district & 39,81 & 38,19 & $-1,62$ \\
\hline Svaliava district & 45,36 & 40,90 & $-4,46$ \\
\hline Tiachiv district & 43,06 & 39,97 & $-3,09$ \\
\hline Khust district & 41,43 & 38,45 & $-2,98$ \\
\hline \multicolumn{5}{|c|}{ Mountain zone } \\
\hline VelykyiBereznyi district & 44,18 & 40,19 & $-3,99$ \\
\hline Volovets district & 46,96 & 47,26 & $+0,34$ \\
\hline Mizhhiria district & 42,96 & 43,30 & $+0,34$ \\
\hline Rakhiv district & 41,80 & 40,73 & $-1,07$ \\
\hline
\end{tabular}

The analysis of Table 4 data indicates the decrease of the hospital bed funds in health care institutions that provide inpatient specialized medical care in $10(71.43 \%)$ administrative territories during the observation period. The highest reduction rate (17.22 beds per 10 thousand population) was registered in Mukachevo district. At the same time, there was an increase in the hospital bed fund in $4(28.57 \%)$ administrative territories. The highest rate of increase (19.80 beds per 10 thousand population) was registered in Uzhhorod district.

The highest hospital bed number in institutions that provide specialized medical care was registered in Uzhhorod - 55.50 per 10 thousand population. There are statistically significant differences in the numbers of hospital beds in specialized medical care institutions in different districts. Thus, the marginal difference of these numbers is 1.67 times ranging from 28.23 in Mukachevo to 47.26 in Volovets districts. 
Besides, there are 25 highly specialized health care facilities in the region, which are the communal property of the regional administration. The highly specialized medical institutions of the region's health care include Transcarpathian Regional Clinical Hospital named after A. Novak, Regional Children's Hospital, Regional Psychiatric Hospital, Regional Clinical Infectious Diseases Hospital, Regional Territorial Medical Phthisiology Association Center, Transcarpathian Regional Clinical Oncology Center, Transcarpathian Regional Drug- and Alcohol-Addiction Center, Regional Hospital of War Veterans, Regional Clinical Center of Neurosurgery and Neurology, etc. These highly specialized medical care facilities have a total of 2,888 beds.

Also, there are other facilities in the region, such as the State Scientific and Practical Medical Rehabilitation Centre of the Ministry of Health of Ukraine and state owned Ukrainian Allergology Hospital.

\section{Characteristics of the regional medical care system personnel}

In total, the health care system of the Transcarpathian region employed 4408 physicians, amounting to 35.1 per 10 thousand population in 2018. Out of the total number of doctors, $70.6 \%$ were certified, including $72.3 \%$ with the highest certification category, $16.4 \%$ with the first certification category and $12.3 \%$ with the second certification category. The regional health care system also employed 9520 mid-level medical practitioners, i.e. 74.9 care providers per 10 thousand population. Out of the total number of mid-level medical care providers, $68.1 \%$ were certified, including $74.2 \%$ with the highest certification category, $14.5 \%$ with the first certification category and $12.1 \%$ with the second certification category.

The ratio of physicians and mid-level medical staff in the health system of the region was 1: 2.18, which is much lower than the WHO recommendations. As a result, doctors are overloaded and perform functions outside their purview.

We have also examined the availability of full-time positions of doctors (except for dentists) in health care facilities in the context of administrative territories and geographical zones in 2014 and 2018. The data obtained are given in Table. 6 .

The analysis of the data given in table 6 indicates that there was a slight tendency in 2018 compared to 2014 towards a reduction of doctors' positions in medical institutions in all administrative territories and geographical zones except Uzhhorod district, where an increase by 50.0 was registered. Most of the full-time positions of doctors are occupied except for Berehove district, where $28.66 \%$ of full-time positions are vacant, as well as Tiachiv and Khust districts, with $9.12 \%$ and $9.21 \%$ of vacant full-time positions respectively. The conducted 
analysis also makes it possible to conclude that not all doctors work full-time in the institutions of such administrative territories as Berehove, Mukachevo, Irshava, Tiachiv and Khust districts.

Table 6

Availability of full-time positions of doctors and their staffing in the health care system of the Transcarpathian region in the context of administrative territories and geographical zones, 2014, 2018

\begin{tabular}{|c|c|c|c|c|c|c|}
\hline \multirow[b]{2}{*}{$\begin{array}{c}\text { Administrative } \\
\text { territories, } \\
\text { geographical zones }\end{array}$} & \multicolumn{3}{|c|}{2014} & \multicolumn{3}{|c|}{2018} \\
\hline & $\stackrel{0}{:}$ & : & 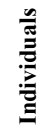 & $\stackrel{\varrho}{\stackrel{\Xi}{\varrho}}$ & 奇 & 芫 \\
\hline \multicolumn{6}{|c|}{ Flatland zone } & \\
\hline Uzhhorod city & 440,00 & 426,00 & 439 & 430,50 & 398,75 & 398 \\
\hline Berehove district & 207,25 & 175,00 & 187 & 206,75 & 147,50 & 155 \\
\hline Vynohradiv district & 283,25 & 264,75 & 245 & 287,00 & 262,25 & 245 \\
\hline Mukachevo district & 478,00 & 457,75 & 482 & 408,50 & 377,0 & 386 \\
\hline Uzhhorod district & 166,00 & 158,25 & 166 & 216,00 & 195,75 & 199 \\
\hline \multicolumn{7}{|c|}{ Foothill zone } \\
\hline Irshava district & 221,00 & 219,00 & 238 & 226,50 & 217,25 & 232 \\
\hline Perechyn district & 82,25 & 77,75 & 71 & 78,50 & 72,25 & 68 \\
\hline Svaliava district & 144,25 & 127,75 & 134 & 144,00 & 118,50 & 126 \\
\hline Tiachiv district & 434,00 & 409,50 & 435 & 419,25 & 381,00 & 400 \\
\hline Khust district & 320,75 & 303,50 & 332 & 331,00 & 300,50 & 321 \\
\hline \multicolumn{7}{|c|}{ Mountain zone } \\
\hline $\begin{array}{l}\text { VelykyiBereznyi } \\
\text { district }\end{array}$ & 65,50 & 63,50 & 64 & 64,50 & 61,25 & 61 \\
\hline Volovets district & 74,25 & 64,50 & 58 & 74,75 & 59,00 & 53 \\
\hline Mizhhiria district & 123,25 & 113,75 & 105 & 115,25 & 101,75 & 105 \\
\hline Rakhiv district & 228,50 & 218,50 & 203 & 229,75 & 216,75 & 199 \\
\hline
\end{tabular}

The data obtained during the research indicate that 1168.75 medical positions were introduced in healthcare institutions that deliver highly specialized medical care; among them 1093, 50 (93.60\%) were occupied by 986 physicians in 2018. In 2014, 1155.75 medical positions were introduced in healthcare institutions of highly specialized medical care; 1101.75 $(95.33 \%)$ of them were occupied by 1027 physicians. This situation indicates that there is a reduction in the number of medical positions, their staffing and the number of physicians working in highly specialized medical care institutions. 
Also, the availability of mid-level health care positions in medical facilities in administrative territories and geographical zones in 2014 and 2018 were studied. The data obtained are given in Table. 7.

Table 7

Availability of positions of mid-level medical workers and their staffing in the health care system of Transcarpathian region in the context of administrative territories and geographical zones in 2014, 2018

\begin{tabular}{|c|c|c|c|c|c|c|}
\hline \multirow[b]{2}{*}{$\begin{array}{c}\text { Administrative } \\
\text { territories, } \\
\text { geographical } \\
\text { zones }\end{array}$} & \multicolumn{3}{|c|}{2014} & \multicolumn{3}{|c|}{2018} \\
\hline & $\frac{n}{b}$ & : & 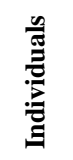 & $\stackrel{n}{: 0}$ & : & $\frac{n}{\underline{E}}$ \\
\hline \multicolumn{6}{|c|}{ Flatland zone } & \\
\hline Uzhhorod city & 671,75 & 647,75 & 669 & 665,25 & 612,25 & 614 \\
\hline Berehove district & 443,25 & 402,25 & 483 & 412,75 & 318,75 & 345 \\
\hline $\begin{array}{c}\text { Vynohradiv } \\
\text { district }\end{array}$ & 671,50 & 646,75 & 773 & 675,25 & 610,50 & 678 \\
\hline $\begin{array}{c}\text { Mukachevo } \\
\text { district }\end{array}$ & 989,00 & 955,75 & 1085 & 790,50 & 755,50 & 845 \\
\hline Uzhhorod district & 278,25 & 253,00 & 247 & 357,00 & 275,25 & 270 \\
\hline \multicolumn{7}{|c|}{ Foothill zone } \\
\hline Irshava district & 634,50 & 632,25 & 911 & 599,75 & 584,25 & 816 \\
\hline Perechyn district & 167,75 & 162,50 & 169 & 149,50 & 137,75 & 136 \\
\hline Svaliava district & 289,25 & 286,75 & 409 & 281,25 & 256,00 & 340 \\
\hline Tiachiv district & 947,75 & 938,25 & 1165 & 860,25 & 804,25 & 976 \\
\hline Khust district & 663,25 & 655,75 & 830 & 674,75 & 659,25 & 774 \\
\hline \multicolumn{7}{|c|}{ Mountain zone } \\
\hline $\begin{array}{c}\text { VelykyiBereznyi } \\
\text { district }\end{array}$ & 155,50 & 154,50 & 165 & 157,25 & 152,75 & 160 \\
\hline Volovets district & 173,25 & 167,50 & 200 & 173,50 & 164,00 & 193 \\
\hline Mizhhiria district & 291,50 & 287,00 & 340 & 287,50 & 277,50 & 329 \\
\hline Rakhiv district & 481,50 & 463,00 & 548 & 485,00 & 441,00 & 510 \\
\hline
\end{tabular}

The analysis of the data presented in Table 7 indicates the stability of full-time positions of mid-level medical staff and their staffing in the healthcare system of the Transcarpathian region. The exception is Tiachiv district where the number of mid-level medical staff positions reduced by $87.50(9.23 \%)$ during the period of five years (2014-2018). At the same time, in Uzhhorod district the number of mid-level medical staff positions increased by 78, 25 (28.30\%) during the period of five years (2014-2018). 
Besides, 2399.50 positions of mid-level medical staff were introduced in health care institutions of highly specialized medical care. $2311(96.31 \%)$ of them were occupied, employing 2386 mid-level medical care providers in 2018. In 2014, 2355.50 mid-level medical staff positions were occupied in health care institutions of highly specialized medical care employing 2465 individuals, thus filling $97.17 \%$ of positions. This emphasizes that mid-level medical staff in highly specialized medical healthcare institutions in the region was preserved.

Taking into account the importance of mid-level medical staff in medical care delivery, we further analyzed the supply of mid-level medical staff in health care facilities of primary and specialized medical care per 10 thousand population in the context of administrative territories and geographical zones in 2014 and 2018. The data obtained are given in Table. 8.

Table 8

Supply of mid-level medical staff in health care facilities of primary and specialized medical care in the context of administrative territories and geographical zones in 2014, 2018 (per 10 thousand population)

\begin{tabular}{|c|c|c|c|c|c|c|}
\hline \multirow[b]{2}{*}{$\begin{array}{l}\text { Administrative } \\
\text { territories, } \\
\text { geographical } \\
\text { zones }\end{array}$} & \multicolumn{3}{|c|}{2014} & \multicolumn{3}{|c|}{2018} \\
\hline & $\stackrel{a}{a}$ & 苞 & 这 & $\stackrel{0}{0}$ & 苞 & 芫起 \\
\hline \multicolumn{6}{|c|}{ Flatland zone } & \\
\hline Uzhhorod city & 58,73 & 56,63 & 58,49 & 59,17 & 54,45 & 54,61 \\
\hline Berehove district & 58,30 & 52,91 & 63,53 & 55,44 & 42,81 & 46,34 \\
\hline $\begin{array}{c}\text { Vynohradiv } \\
\text { district }\end{array}$ & 55,77 & 53,72 & 64,20 & 55,68 & 50,34 & 55,91 \\
\hline $\begin{array}{c}\text { Mukachevo } \\
\text { district }\end{array}$ & 53,19 & 51,40 & 58,35 & 42,59 & 40,70 & 45,52 \\
\hline Uzhhorod district & 35,30 & 32,09 & 31,33 & 49,82 & 38,41 & 37,68 \\
\hline \multicolumn{7}{|c|}{ Foothill zone } \\
\hline Irshava district & 63,67 & 63,45 & 91,42 & 59,61 & 58,07 & 81,10 \\
\hline Perechyn district & 52,59 & 50,94 & 52,98 & 46,42 & 42,77 & 42,23 \\
\hline Svaliava district & 53,55 & 53,09 & 75,73 & 52,06 & 47,38 & 62,93 \\
\hline Tiachiv district & 54,42 & 53,87 & 66,89 & 49,12 & 45,92 & 55,73 \\
\hline Khust district & 52,04 & 51,45 & 65,12 & 52,95 & 51,73 & 60,74 \\
\hline \multicolumn{7}{|c|}{ Mountain zone } \\
\hline $\begin{array}{c}\text { VelykyiBereznyi } \\
\text { district }\end{array}$ & 58,22 & 57,84 & 61,77 & 59,07 & 57,38 & 60,10 \\
\hline Volovets district & 70,74 & 68,39 & 81,66 & 71,31 & 67,40 & 79,32 \\
\hline Mizhhiria district & 60,79 & 59,85 & 70,90 & 60,44 & 58,34 & 69,16 \\
\hline Rakhiv district & 52,28 & 50,27 & 59,50 & 52,12 & 47,39 & 54,81 \\
\hline
\end{tabular}


The analysis of the data given in table 8 indicates that the supply of midlevel medical staff in the primary and specialized health care facilities per 10 thousand people in administrative territories is statistically significant and fluctuates 1.67 times. Thus, the lowest supply of mid-level medical staff (42.59) was registered in Mukachevo district and the highest (71.31) in Volovets district.

In general, the supply of mid-level medical staff is highest in the mountainous areas in terms of geographical zones.

The rate of mid-level medical staff in the Transcarpathian region as a whole decreased from 73.47 to 71.69 per 10 thousand population (by 1.78 positions for every 10 thousand people) in the period from 2014 to 2018. At the same time, none of the positions in 15 (5.77\%) FeldscherMidwife units out of total 260 is occupied by a medical professional.

In order to provide a comprehensive understanding of the health care of the region we have researched and presented data on the system of emergency medical care provided to the population. The obtained data are presented in table 9. The Transcarpathian Territorial Center of Emergency Medical Care (TTCEMC) carries out the organization of emergency medical care in the region. There are 14 emergency medical care units in the region, which employ 154 doctors and 589 junior specialists with medical education.

Table 9

Emergency medical service network and staff of the Transcarpathian region, 2018

\begin{tabular}{|c|c|c|c|c|c|c|c|}
\hline \multirow[b]{2}{*}{$\begin{array}{l}\text { Administrative } \\
\text { territories }\end{array}$} & \multirow[b]{2}{*}{$\begin{array}{c}\text { Total } \\
\text { positions }\end{array}$} & \multicolumn{3}{|c|}{ Positions of physicians } & \multicolumn{3}{|c|}{$\begin{array}{c}\text { Positions of mid-level medical } \\
\text { staff }\end{array}$} \\
\hline & & 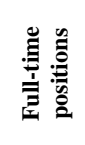 & 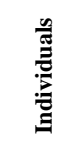 & 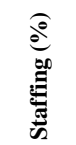 & 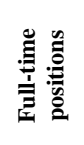 & 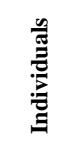 & 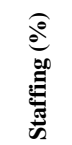 \\
\hline 1 & 2 & 3 & 4 & 5 & 6 & 7 & 8 \\
\hline $\begin{array}{c}\text { Transcarpathian } \\
\text { regional center of } \\
\text { emergency } \\
\text { medical care }\end{array}$ & 1325,75 & 180,75 & 154,00 & 85,20 & 544,50 & 589,00 & 96,87 \\
\hline \multicolumn{8}{|c|}{ Emergency medical care units } \\
\hline district & 60,50 & 5,50 & 4,00 & 72,73 & 28,00 & 27,00 & 96,43 \\
\hline $\begin{array}{l}\text { VelykyiBereznyi } \\
\text { district }\end{array}$ & 42,00 & 4,50 & 4,00 & 88,89 & 22,50 & 22,00 & 97,78 \\
\hline $\begin{array}{c}\text { Vynohradiv } \\
\text { district }\end{array}$ & 88,50 & 5,50 & 4,00 & 72,73 & 41,50 & 48,00 & 100,0 \\
\hline Volovets district & 35,50 & 5,50 & 4,00 & 72,73 & 13,50 & 14,00 & 100,0 \\
\hline Irshava district & 90,25 & 5,50 & 4,00 & 72,73 & 42,25 & 44,00 & 100,0 \\
\hline
\end{tabular}


Continuation of Table 9

\begin{tabular}{|c|c|c|c|c|c|c|c|}
\hline $\mathbf{1}$ & $\mathbf{2}$ & $\mathbf{3}$ & $\mathbf{4}$ & $\mathbf{5}$ & $\mathbf{6}$ & $\mathbf{7}$ & $\mathbf{8}$ \\
\hline Mizhhiria district & 82,50 & 5,50 & 4,00 & 72,73 & 36,75 & 47,00 & 100,0 \\
\hline $\begin{array}{c}\text { Mukachevo } \\
\text { district }\end{array}$ & 204,50 & 37,00 & 36,00 & 97,30 & 82,50 & 95,00 & 100,0 \\
\hline Perechyn district & 43,50 & 5,50 & 5,00 & 90,91 & 18,00 & 16,00 & 88,89 \\
\hline Rakhiv district & 72,50 & 5,50 & 5,00 & 100 & 35,00 & 31,00 & 88,57 \\
\hline Svaliava district & 41,50 & 5,50 & 3,00 & 54,55 & 18,00 & 19,00 & 100,0 \\
\hline Tiachiv district & 160,00 & 5,50 & 5,00 & 90,91 & 72,50 & 89,00 & 100,0 \\
\hline Uzhhorod district & 77,50 & 18,50 & 13,00 & 70,27 & 27,00 & 26,00 & 96,30 \\
\hline Khust district & 81,00 & 11,00 & 10,00 & 90,91 & 36,50 & 37,00 & 100,0 \\
\hline Uzhhorod & 164,25 & 45,50 & 42,00 & 92,31 & 47,00 & 54,00 & 100,0 \\
\hline $\begin{array}{c}\text { Administrative } \\
\text { and managerial } \\
\text { staff }\end{array}$ & 81,75 & 15,25 & 11,00 & 72,13 & 23,50 & 20,00 & 85,11 \\
\hline
\end{tabular}

\section{CONCLUSIONS}

The conducted analysis of the health care institutions network and health care personnel in the Transcarpathian region showed that there are 646 health care facilities and separate structural divisions in the region, of which $91.18 \%$ provide primary care, $4.95 \%$ provide specialized and $3.87 \%$ highly specialized medical care. Besides, there is an emergency medical care unit in each administrative territory.

The planned capacity of outpatient clinics for providing specialized medical care and the availability of hospital beds have statistically significant differences in the context of administrative zones.

Statistically significant differences were also established in the supply of medical staff in the context of administrative territories. At the same time, a common problem for all administrative territories is the tendency towards a reduction of the positions and low ratio of physicians and mid-level medical staff; as a result, physicians perform functions outside their purview.

\section{SUMMARY}

The conducted analysis of the health care institutions network and health care personnel in the Transcarpathian region showed that there are 646 health care facilities and separate structural divisions in the region, of which $91.18 \%$ provide primary care, $4.95 \%$ provide specialized and $3.87 \%$ highly specialized medical care. Besides, there is an emergency medical care unit in each administrative territory.

The planned capacity of outpatient clinics to provide specialized medical care and the availability of hospital beds have statistically significant differences in the context of administrative zones.

The availability of hospital beds for specialized inpatient care in the districts fluctuates 1.67 times: from 28.23 in Mukachevo district to 47.26 in 
Volovets district, whereas there are 55.50 beds per 10 thousand population in Uzhhorod. At the same time, highly specialized medical care facilities have a total of 2,888 beds.

The article shows that the Transcarpathian health care system employed 4408 physicians (without managerial staff and dentists), which accounted for 35.1 per 10 thousand population in 2018. Out of the total number of doctors, $70.6 \%$ were certified, including $72.3 \%$ with the highest certification category, $16.4 \%$ with the first certification category and $12.3 \%$ with the second certification category. The health care system of the region also employed 9520 mid-level medical staff, i.e. 74.9 per 10 thousand population. Out of the total number of mid-level medical staff, $68.1 \%$ were certified, including $74.2 \%$ with the highest certification category, $14.5 \%$ with the first certification category and $12.1 \%$ with the second certification category.

Statistically significant differences were also established in the supply of medical staff in the context of administrative territories. At the same time, a common problem for all administrative territories is the tendency towards a reduction of staff positions and low ratio of physicians and mid-level medical staff.

\section{REFERENCES}

1. Stratehichna doradcha hrupa z pytan reformuvannia systemy okhorony zdorovia v Ukraini (2015) Natsionalna stratehiia reformuvannia systemy okhorony zdorovia v Ukraini na period 2015-2020 rokiv [National Health Care Reform Strategy in Ukraine for the period of 2015-2020], pp. 41. Retrived from: http://healthsag.org.ua/strategiya/

2. Lekhan V.M., Slabkyi H.O., Shevchenko M.V. (2015) Analiz rezultativ reformuvannia systemy okhorony zdorovia $\mathrm{v}$ pilotnykh rehionakh: pozytyvni naslidky, problemy ta mozhlyvi shliakhy yikh vyrishennia [Analyzing health reform outcomes in pilot regions: positive impacts, challenges, and possible solutions]. Zdorovia Natsii, vol. 3 (Special issue), pp. 67-86.

3. Slabkyi H.O., Lekhan V.M. (2015) Uroky reformy okhorony zdorovia v Ukraini: dosiahnennia, nevyrisheni pytannia, ryzyky, problemy [Healthcare reform lessons in Ukraine: achievements, unresolved issues, risks, challenges]. Proceedings of the International Conference "Orhanizatsiia i upravlinnia okhoronoiu zdorovia" (Ukraine, October 20-21, 2015), pp. 26-27.

4. Slabkyi H. O., Zozulia I.S., Zozulia A.I. (2014) Priorytetnyi rozvytok pervynnoi medyko-sanitarnoi dopomohy na zasadakh simeinoi medytsyny 
[Priority development of primary health care based on family medicine]. Simeina medytsyna, vol. 3, No. 53, pp. 25-27.

5. Lekhan V. M., Nadutyi K.O., Slabkyi H.O. (2011) Innovatsiini pidkhody do zabezpechennia dostupnosti pervynnoi medyko-sanitarnoi dopomohy silskomu naselenniu [Innovative approaches to ensuring the availability of primary health care to the rural population]. Zdorovia natsii, vol. 3, No. 19, pp. 86-91.

6. Matiukha L.F., Lekhan V.M., Hoida N.H. et al. (2011) Poriadok orhanizatsii nadannia medychnoi dopomohy ta zabezpechennia marshrutiv patsiienta likarem zahalnoi praktyky - simeinym likarem pry riznykh klinichnykh stanakh ta zakhvoriuvanniakh [The procedure for the organization of care and providing pathways by a general practitioner family physician in different clinical conditions and diseases]. Ministry of Health of Ukraine; National Medical Academy of Post-Graduate Education named after P. L. Shupyk, Ukrainian Institute for Social Research, Dnipropetrovsk State Medical Academy, Zaporizzhia Medical PostGraduate Academy, Chernivtsi Health Care Department, p. 43.

7. Parkhomenko H. Ya. (2011) Likarnia intensyvnoi dopomohy likarnia yevropeiskoho zrazka [Intensive care hospital - a European-style hospital]. Visnyk sotsialnoi hihiieny ta orhanizatsii okhorony zdorovia Ukrainy, vol. 2, pp. 39-41.

8. Kotenko S.L. (2015) Derzhavne rehuliuvannia kadrovoi polityky haluzi okhorony zdorovia [State regulation of the personnel policy of the health care industry]. Proceedings of the Conference "Zavdannia derzhavy $\mathrm{u}$ zabezpechenni efektyvnoi kadrovoi polityky systemy okhorony zdorovia" (Ukraine, Kyiv, April 22, 2015), pp. 56-59.

9. Zakon Ukrainy vid 19 zhovtnia 2017 roku 2168-VIII (2017) Pro derzhavni finansovi harantii medychnoho obsluhovuvannia naselennia [Law of Ukraine On State Financial Guarantees of Public Health Services: Law of Ukraine of October 19, 2017 No. 2168-VIII]. Retrieved from: http://search.ligazakon.ua/l_doc2.nsf/link1/T172168.html

10. Skryp V. V., Slabkyi H.O. (2015) Metodychni pidkhody do avtonomizatsii zakladiv okhorony zdorovia [Methodological approaches to the autonomy of health care institutions]. Intermedical Journal, vol. IV, No. 6, pp. 20-25.

11. Rohach I.M., Danko D.V. (2019) Kharakterystyka naselennia Zakarpatskoi oblasti [Characteristics of the population of the Transcarpathian region]. Ekonomika i pravo okhorony zdorovia, vol. 1, No. 9, pp. 75-78. 
12. Zakarpatskyi oblasnyi medychnyi informatsiino-analitychnyi tsentr (2015) Merezha zakladiv ta osnovni pokaznyky diialnosti systemy okhorony zdorovia Zakarpatskoi oblasti za 2014 rik. [Network of institutions and key indicators of health care system activity in Transcarpathian region for 2014] Uzhhorod: Zakarpatskyi oblasnyi medychnyi informatsiino-analitychnyi tsentr.

13. Zakarpatskyi oblasnyi medychnyi informatsiino-analitychnyi tsentr (2019) Merezha zakladiv ta osnovni pokaznyky diialnosti systemy okhorony zdorovia Zakarpatskoi oblasti za 2018 rik [The network of institutions and key indicators of the health care system of Transcarpathian region for 2018] Uzhhorod: Zakarpatskyi oblasnyi medychnyi informatsiino-analitychnyi tsentr.

Information about the author: Danko D. V., orcid.org/0000-0003-2992-5333 Associate Professor at the Department of Social Medicine and Hygiene Uzhhorod National University 1, Narodna Sq., 88000, Uzhhorod, Ukraine 


\section{ANALYSIS OF INDICATORS OF DENTAL HEALTH'S ADULT POPULATION OF THE TRANSCARPATHIA REGION AND PROVIDING THEM SPECIALIZED MEDICAL CARE IN THE PUBLIC HEALTH SECTOR}

\section{Pishkovtsi A.-M. M.}

\section{INTRODUCTION}

According to experts, oral health is one of the fundamental foundations of general human health. According to official WHO statistics, about $98 \%$ of people in the world suffer from inflammatory diseases of periodontal tissues. The incidence of caries is also almost $100 \%{ }^{1}$. In order to protect the dental health population, one of the most important goals is to control the European strategic organization of protecting the health by achieving good health for all ${ }^{2}$.

In 2003, the World Health Organization, together with the International Federation of Dentists, proposed new global goals for dental health for the period up to $2020^{3}$. Unlike previous global goals, which indicated specific numbers, there are no new goals for them, since the variability indicators of dental morbidity in the world does not allow to determine even approximate averaged indicators. WHO recommends the development of measurable dental health goals in each country based on proposed global goals by 2020 .

${ }^{1}$ Department of Health Statistics and Informatics, World Health Organization Information, Evidence and Research Group (2013) My`rovaya staty`sty ka 2013 [World Statistics 2013], Department of Health Statistics and Informatics, World Health Organization Information, Evidence and Research Group. Retrieved from: http://www.who.int/gho/publications/ world_health_statistics/2013/en/index.html. (accessed 18 November 2019)

${ }^{2}$ European Series on Health for All (2005) Osnovy politiki dostizheniya zdorovya dlya vseh v Evropejskom regione VOZ [Health for All Policy Framework for the WHO European Region]. European Series on Health for All (electronic journal) no. 7, 98 pp. Retrieved from: http://www.euro.who.int/ru/publications/abstracts/health21-the-health-for-all-policyframework-for-the-who-european-region (accessed 17 November 2019)

${ }^{3}$ FDI General Assembly (2003) Zayavlenie mezhdunarodnoj stomatologicheskoj associacii (FDI) «Globalnye celi v oblasti stomatologicheskogo zdorovya (Sovmestnoe zayavlenie FDI VOZ - IADR)» [Statement of the International Dental Association (FDI) «Global Dental Health Goals (Joint Statement of FDI-WHO-IADR)»]. FDI General Assembly. Retrieved from: http://www.e-stomatology.ru/star/ info/fdi/fdi_global. Htm (accessed 14 November 2019) 
The importance of dental health is also indicated by the fact that in 2013 the World Dental Federation FDI established the World Oral Health Day $(\mathrm{WOHD})^{4}$.

The current state of dental health of the population of Ukraine is characterized by a high prevalence of dental diseases, curtailment of preventive measures, and a reduction in government funding for the dental service ${ }^{5}$.

In Ukraine, the number of dentists (public and private dentistry) is 6.2 per 10 thousand people, including state ownership - 4.56 per 10 thousand. According to statistics from the Ministry of Health (MoH) of Ukraine, the majority of the population (> 80\%) receives dental care in public health institutions of state ownership ${ }^{6}$.

In most European countries, $80-85 \%$ of dentists are general practitioners. They work on the principle of a family doctor and, while treating the most common diseases of the teeth, oral cavity and maxillofacial region, they carry out preventive measures for adults and children. Only $15-20 \%$ of doctors provide specialized or highly specialized dental care. State programs for the prevention of dental diseases are developed and work ${ }^{7}$. In Ukraine, dental disease prevention programs have not been implemented.

After the introduction of the internship in Dentistry in 2006 in Ukraine, the share of dentists (general practitioners) grew to $70 \%$. The rest are doctors of specialization. In accordance with the existing qualification characteristics, the dentist performs the functions of a family dentist or general practitioner and must provide primary dental care, as well as carry out preventive measures on an outpatient basis.

However, organizationally this issue has not been resolved today. According to the current legislation, all dentists are legally assigned to the secondary level of medical care, although most of them work at the primary level of dental care.

A particularly difficult situation with dental care has developed in rural areas. After the dentist ceased to be present at the primary level, the mass

\footnotetext{
4 PII Vsemirnaya stomatologicheskaya federaciya [FDI World Dental Federation] Retrieved from:https://www.fdiworlddental.org/ (accessed 17 November 2019)

${ }^{5}$ Vahnenko O. M. (2011) Analiz resursnogo zabezpechennya stomatologichnoyi sluzhbi v Ukrayini [Analyze of resource care of dental service in Ukraine]. Modern dentistry,no. 3, pp. $172-176$.

${ }^{6}$ Yu.V.Voronenko, O.V.Pavlenko, I.P.Mazur (2018) Stomatologichna dopomoga $v$ Ukrayini: osnovni pokazniki diyalnosti za 2008-2018 roki [Dental auxiliaries in Ukraine: the main displays of activity in 2008-2018: pre-historic]. Kropivnitsky: Polium. (in Ukrainian)

${ }^{7}$ Kostlan Ya. (1982) Stomatologicheskoe obsluzhivanie v Evrope [Dental care in Europe] World Health Organization. European Regional Office. Copenhagen
} 
liquidation of dental offices and the reduction of dental positions began. There is no activity in the emergence of private dental offices, especially in remote villages, due to a lack of funds for the local population.

In 2017, the Verkhovna Rada of Ukraine adopted a number of laws aimed at changes in the health care system, in particular: "On amendments to some legislative acts of Ukraine regarding improvement of legislation on the activities of health care institutions ${ }^{8}$, , On state financial guarantees of public health services» ${ }^{9}$. The Ministry of Health of Ukraine announced the reform of the healthcare system, including the introduction of the principle "money goes for the patient", and a change in the principles of financing primary health care in $2018^{10}$.

The fundamentals of Ukrainian legislation on health care ${ }^{11}$ determine that primary medical care provides for counseling, diagnosis and treatment of the most common diseases, injuries, poisoning, pathological, physiological (during pregnancy) conditions, the implementation of preventive measures and referral in accordance with the medical indications of the patient, who does not need emergency medical care to provide him with secondary (specialized) or tertiary (high-specialist reshape the company), medical care and emergency medical care in the cases. According to the new edition of the third part of Art. 351 of the Fundamentals of the legislation of Ukraine on health care, primary care is provided by general

\footnotetext{
${ }^{8}$ Pro vnesennya zmin do deyakih zakonodavchih aktiv Ukrayini shodo udoskonalennya zakonodavstva z pitan diyalnosti zakladiv ohoroni zdorov'ya [On Introduction of Wetlands to the Actual Legislative Acts of Ukraine on Food and Nutrition Legislation on Health Protection]: Zakon Ukrayini vid 06.04.2017 r. № 2002 [Law of Ukraine no. 2002 of 06.04.2017]. Retrieved from:http://www.ukrainepravo.com/law-making/bill_passed_by_legislature/zakon-ukraini-provnesennya-zmin-do-deyakikh-zakonodavchikh-aktiv-ukraini-shchodo-udoskonalennya-zak/ (accessed 15 November 2019)

${ }^{9}$ Pro derzhavni finansovi garantiyi medichnogo obslugovuvannya naselennya [On Holders of Financial Guarantees for Medical Services to the Population]: Zakon Ukrayini vid 19 zhovtnya 2017 roku № 2168-VIII [Law of Ukraine No. 2168-VIII of June 19, 2017]. Retrieved from: http://search.ligazakon.ua/__doc2.nsf/link1/T172168.html (accessed 14 November 2019)

10 Pro zatverdzhennya Poryadku realizaciyi derzhavnih garantij medichnogo obslugovuvannya naselennya za programoyu medichnih garantij dlya pervinnoyi medichnoyi dopomogi na 2018 rik [On Approval of the Procedure for Realization of the Realization of the Population's Healthcare Guarantees for the Program of Medical Guarantees for Primary Medical Assistance for 2018]: Postanova KMU vid 25.04.2018 r. № 407 [Resolution of the Cabinet of Ministers of Ukraine No. 407 dated 25.04.2018]. Retrieved from: https://www.apteka.ua/article/458646 (accessed 13 November 2019)

${ }^{11}$ Osnovi zakonodavstva Ukrayini pro ohoronu zdorov'ya [On Healthy Hunting Legislation of Ukraine]: Zakon Ukrayini vid 19 listopada 1992 roku № 2801-XII [Law of Ukraine No. 2801-XII of November 19, 1992]. Retrieved from: https://zakon.rada.gov.ua/laws/show/280112 (accessed 17 November 2019)
} 
practitioners - family doctors and doctors of other specialties, defined by the central executive body that ensures the formation of state policy in the field of health care, and other medical workers working under their supervision. At the same time, dentists, in fact being the doctors of the first contact for patients with diseases of the teeth and maxillofacial region, are not assigned to primary care physicians in the country.

Based on the foregoing, it follows that the optimization of dental care for the population during the reform of the healthcare system requires an analysis of the level of dental health of the population and the existing dental care system.

\section{Analysis of adult dental health in Transcarpathian region}

The analysis of dental health of the adult population of Transcarpathian region and the provision of specialized dental care in the public health sector was carried out using data from the Department of Health of the Transcarpathian Regional State Administration for the period 2014$2018^{12,13,14,15,16}$.

When studying the dental health status of the adult population of the Transcarpathian region, the following indicators were studied and analyzed:

\footnotetext{
${ }^{12}$ Transcarpathian Regional Medical Information and Analytical Center (2015) Merezha zakladiv ta osnovni pokazniki diyalnosti sistemi ohoroni zdorov'ya Zakarpatskoyi oblasti za 2014 rik [The extent of laying and the main indicators of health care system of Transcarpathian region in 2014]. Uzhgorod: Transcarpathian Regional Medical Information and Analytical Center (in Ukrainian)

${ }^{13}$ Transcarpathian Regional Medical Information and Analytical Center (2016) Merezha zakladiv ta osnovni pokazniki diyalnosti sistemi ohoroni zdorov'ya Zakarpatskoyi oblasti za 2015 rik [The extent of laying and the main indicators of health care system of Transcarpathian region in 2015]. Uzhgorod: Transcarpathian Regional Medical Information and Analytical Center (in Ukrainian)

${ }^{14}$ Transcarpathian Regional Medical Information and Analytical Center (2017) Merezha zakladiv ta osnovni pokazniki diyalnosti sistemi ohoroni zdorov'ya Zakarpatskoyi oblasti za 2016 rik [The extent of laying and the main indicators of health care system of Transcarpathian region in 2016]. Uzhgorod: Transcarpathian Regional Medical Information and Analytical Center (in Ukrainian)

${ }^{15}$ Transcarpathian Regional Medical Information and Analytical Center (2018) Merezha zakladiv ta osnovni pokazniki diyalnosti sistemi ohoroni zdorov'ya Zakarpatskoyi oblasti za 2017 rik [The extent of laying and the main indicators of health care system of Transcarpathian region in 2017]. Uzhgorod: Transcarpathian Regional Medical Information and Analytical Center (in Ukrainian)

${ }^{16}$ Transcarpathian Regional Medical Information and Analytical Center (2019) Merezha zakladiv ta osnovni pokazniki diyalnosti sistemi ohoroni zdorov'ya Zakarpatskoyi oblasti za 2018 rik [The extent of laying and the main indicators of health care system of Transcarpathian region in 2018]. Uzhgorod: Transcarpathian Regional Medical Information and Analytical Center (in Ukrainian)
} 
the incidence of the adult population of the region for caries, periodontal disease, diseases of the mucous membrane of the cavity, as well as the prevalence of adult caries, periodontal disease and diseases of the oral mucosa per 10 thousand adult population of the area. All indicators are recorded on the basis of population overtures for dental medical care in public health institutions, so we can talk not about «objective data on the state of dental health» in the adult population of the region, but only about trends.

In the table. 1 shows data on prevalence rates among the adult population of the area of dental caries.

Table 1

The prevalence of dental caries among the adult population (per 10 thousand adults), 2014-2018

\begin{tabular}{|c|c|c|c|c|c|}
\hline Administrative territory & $\mathbf{2 0 1 4}$ & $\mathbf{2 0 1 5}$ & $\mathbf{2 0 1 6}$ & $\mathbf{2 0 1 7}$ & $\mathbf{2 0 1 8}$ \\
\hline Uzhgorod city & 24171,89 & 17036,23 & 13194,75 & 15975,25 & 15837,55 \\
\hline \multicolumn{6}{|c|}{ Districts } \\
\hline Beregovsky & 19042,14 & 18904,70 & 18404,72 & 84688,19 & 22290,31 \\
\hline Vinogradovsky & 8885,48 & 9898,59 & 13557,66 & 16541,84 & 12838,72 \\
\hline Velykyi Bereznyi & 9244,31 & 11920,27 & 10831,24 & 11378,74 & 15229,71 \\
\hline Volovetsky & 7077,43 & 17365,88 & 24880,10 & 8528,72 & 12688,99 \\
\hline Irshavsky & 14435,10 & 14012,98 & 14415,88 & 14003,88 & 14372,56 \\
\hline Mizhhirskyi & 11092,43 & 16231,27 & 12224,86 & 16772,10 & 20180,43 \\
\hline Mukachevo & 15819,12 & 15402,26 & 15908,43 & 22904,77 & 13569,24 \\
\hline Perechyn & 16345,09 & 27513,01 & 13290,19 & 19921,04 & 17017,03 \\
\hline Rakhiv & 19460,13 & 16593,45 & 17129,80 & 20160,80 & 19628,46 \\
\hline Svalyavsky & 21404,87 & 19786,17 & 23170,16 & 12192,68 & 19133,81 \\
\hline Tyachivsky & 17636,84 & 18268,45 & 28701,62 & 30214,37 & 42545,05 \\
\hline Uzhgorod & 13061,54 & 14689,08 & 15862,16 & 15564,80 & 16499,05 \\
\hline Khust & 17353,43 & 17637,82 & 18784,84 & 17612,69 & 19484,71 \\
\hline All over the region & 15130,14 & 15469,29 & 17749,40 & 20499,38 & 20405,60 \\
\hline
\end{tabular}

An analysis of the data in Table 1 showed that over the period of the study (2014-2018), the prevalence rate among the adult population of the area of dental caries increased 1.35 times and amounted to 20405.60 per 10 thousand population. The growth of this indicator was registered in 10 (71.43\%) of the administrative territories of the region. The highest levels of growth in prevalence among adults in the area of dental caries were recorded in Mizhhirskyi (1.82 times) and Tyachiv (2.41 times) districts. In the context of the administrative territories of the region, statistically significant differences of this indicator were recorded from 12688.99 in Volovetsky to 42545.05 per 10 thousand of the adult population in Tyachiv district. 
The next step in the study was to study the prevalence of adult periodontal disease in adults. The results are shown in table 2 .

Table 2

The prevalence of periodontal disease among the adult population (per 10 thousand adults), 2014-2018

\begin{tabular}{|c|c|c|c|c|c|}
\hline Administrative territory & $\mathbf{2 0 1 4}$ & $\mathbf{2 0 1 5}$ & $\mathbf{2 0 1 6}$ & $\mathbf{2 0 1 7}$ & $\mathbf{2 0 1 8}$ \\
\hline Uzhgorod city & 497,81 & 1690,41 & 2257,90 & 2060,64 & 2259,34 \\
\hline \multicolumn{5}{|c|}{ Districts } \\
\hline Beregovsky & 456,19 & 478,93 & 478,10 & 508,30 & 625,39 \\
\hline Vinogradovsky & 132,26 & 291,45 & 469,49 & 175,82 & 182,49 \\
\hline Velykyi Bereznyi & 265,08 & 496,09 & 337,51 & 164,29 & 225,59 \\
\hline Volovetsky & 524,55 & 3657,21 & 1972,35 & 412,19 & 377,09 \\
\hline Irshavky & 332,02 & 571,65 & 279,37 & 89,30 & 68,00 \\
\hline Mizhhirskyi & 81,52 & 215,90 & 219,50 & 193,74 & 454,11 \\
\hline Mukachevo & 243,28 & 335,75 & 256,78 & 102,21 & 30,65 \\
\hline Perechyn & 475,08 & 816,93 & 202,09 & 506,69 & 373,52 \\
\hline Rakhiv & 381,58 & 136,60 & 98,84 & 50,93 & 48,97 \\
\hline Svalyavsky & 1939,19 & 409,40 & 4382,85 & 2827,78 & 1426,25 \\
\hline Tyachivsky & 524,61 & 785,46 & 1763,14 & 4788,71 & 4005,44 \\
\hline Uzhgorod & 247,63 & 237,74 & 2092,12 & 565,49 & 553,70 \\
\hline Khust & 134,25 & 155,09 & 137,47 & 132,48 & 70,63 \\
\hline All over the region & 370,75 & 522,70 & 946,42 & 1186,59 & 1050,65 \\
\hline
\end{tabular}

According to the data given in table 2 shows that the prevalence rate among the adult population of the region during the observation (2014-2018) of periodontal disease increased by 2.83 times and amounted to 1050.65 per 10 thousand of the adult population with territorial marginal differences of 130.68 times. The lowest prevalence rate among the adult population of the area of periodontal disease (30.65) was recorded in Mukachevo, and the most (4005.44) in Tyachiv district. During the study period, a decrease in the prevalence rate of periodontal disease among adults in the region of periodontal disease was recorded in $8(57.14 \%)$ administrative territories, and its growth was recorded in $6(42.86 \%)$ administrative territories. At the same time, the highest level of decline in this indicator was recorded in Irshavsky (4.88 times), Mukachevo (7.94 times) and Rakhovsky (7.79 times) districts, and the highest level of growth of this indicator was recorded in Mizhhirskyi (5.57 times) and Tyachiv (7.64 times) districts. This situation is associated with different levels of access to dental care for the population, especially for those who live in remote areas.

In accordance with the research program, the next step was to study the prevalence among adults of the area of diseases of the oral mucosa in the dynamics of 2014-2018. The data obtained are given in table 3. 
Table 3

The prevalence among the adult population of the area of diseases of the oral mucosa (per 10 thousand adults), 2014-2018

\begin{tabular}{|c|c|c|c|c|c|}
\hline Administrative territory & 2014 & 2015 & 2016 & 2017 & 2018 \\
\hline Uzhgorod city & 255,87 & 128,33 & 235,72 & 293,40 & 460,81 \\
\hline \multicolumn{6}{|c|}{ Districts } \\
\hline Beregovsky & 23,70 & 9,13 & 12,57 & 27,58 & 50,37 \\
\hline Vinogradovsky & 76,54 & 89,21 & 123,91 & 78,35 & 77,03 \\
\hline Velykyi Bereznyi & 75,17 & 78,20 & 68,42 & 88,46 & 100,44 \\
\hline Volovetsky & 206,10 & 1933,87 & 486,07 & 422,70 & 336,56 \\
\hline Irshavsky & 85,56 & 100,02 & 89,62 & 85,01 & 70,04 \\
\hline Mizhhirskyi & 81,52 & 104,49 & 70,12 & 136,01 & 116,25 \\
\hline Mukachevo & 76,51 & 48,72 & 35,62 & 25,15 & 44,05 \\
\hline Perechyn & 32,06 & 52,05 & 31,79 & 65,80 & 83,39 \\
\hline Rakhiv & 143,80 & 21,06 & 21,38 & 18,26 & 26,01 \\
\hline Svalyavsky & 251,70 & 251,53 & 751,21 & 2121,33 & 2729,85 \\
\hline Tyachivsky & 119,65 & 125,11 & 149,90 & 146,54 & 127,41 \\
\hline Uzhgorod & 96,87 & 102,85 & 1676,65 & 511,70 & 296,12 \\
\hline Khust & 11,58 & 25,85 & 71,43 & 178,70 & 33,63 \\
\hline All over the region & 101,15 & 118,12 & 234,92 & 262,84 & 282,63 \\
\hline
\end{tabular}

Prevalence rates among adults of the oral mucosa (Table 3) increased 2.79 times during the observation years and amounted to 282.63 per 10 thousand adults of the region. At the same time, the limit indicators in the context of the administrative territories of the region fluctuate 104.95 times: from 26.01 in Rakhiv to 2729.85 per 10 thousand adults in the Svalyava district with an increase of the indicated indicator in the district in the years of study 10.85 times. This requires a special study to investigate the causes of the extremely high incidence of adult oral mucosal disease and the rapid rate of increase in the prevalence of the disease in the adult population.

Further, the indicators of morbidity of the adult population of the Transcarpathian region for major dental diseases were studied. Table 4 shows the data on the incidence of the adult population of dental caries.

According to table 4 shows that the incidence of adult population of the region for dental caries in the study period increased by 1.06 times and amounted to 7207,73 per 10 thousand adults. The marginal difference of the indicated indicator in the section of administrative territories makes 17,51 times: from 979,81 in Mukachevo to 17160,07 in Tyachivsky district. With an increase in the period of the study, the incidence of adult caries in the dental caries was registered in $7(50.0 \%)$ administrative territories of the region. 
Table 4

The incidence of adult dental caries in the region (per 10 thousand adults), 2014-2018

\begin{tabular}{|c|c|c|c|c|c|}
\hline Administrative territory & $\mathbf{2 0 1 4}$ & $\mathbf{2 0 1 5}$ & $\mathbf{2 0 1 6}$ & $\mathbf{2 0 1 7}$ & $\mathbf{2 0 1 8}$ \\
\hline Uzhgorod city & 4146,57 & 3946,88 & 3124,84 & 4171,09 & 4778,99 \\
\hline \multicolumn{5}{|c|}{ Districts } \\
\hline Beregovsky & 6545,06 & 5881,08 & 6428,91 & 22925,01 & 5422,74 \\
\hline Vinogradovsky & 5591,61 & 5746,90 & 5452,49 & 9855,75 & 7242,95 \\
\hline Velykyi Bereznyi & 4500,41 & 4490,10 & 4597,77 & 4364,52 & 4522,74 \\
\hline Volovetsky & 5232,25 & 5919,72 & 6119,55 & 3887,17 & 3848,74 \\
\hline Irshavsky & 9321,33 & 8850,41 & 9353,20 & 8974,33 & 8264,55 \\
\hline Mizhhirskyi & 5418,12 & 5809,96 & 5527,98 & 5854,26 & 4624,41 \\
\hline Mukachevo & 6574,32 & 4988,06 & 4569,22 & 1944,16 & 979,81 \\
\hline Perechyn & 4717,96 & 5112,70 & 4935,08 & 3835,30 & 4132,91 \\
\hline Rakhiv & 8078,56 & 8072,31 & 8098,89 & 9199,06 & 9350,63 \\
\hline Svalyavsky & 8166,11 & 8103,50 & 9592,50 & 5917,43 & 9156,20 \\
\hline Tyachivsky & 8431,32 & 7737,67 & 11684,34 & 12458,57 & 17160,07 \\
\hline Uzhgorod & 5795,66 & 7004,18 & 6054,74 & 5421,14 & 6210,49 \\
\hline Khust & 7187,32 & 7035,32 & 7121,19 & 7605,67 & 5924,52 \\
\hline All over the region & 6793,49 & 6488,33 & 6866,24 & 7626,66 & 7207,73 \\
\hline
\end{tabular}

Table 5

Adult incidence of periodontal disease

with the highest and lowest rates in terms of administrative territories (per 10 thousand adult population), 2014-2018

\begin{tabular}{|c|c|c|c|c|c|}
\hline Administrative territory & $\mathbf{2 0 1 4}$ & $\mathbf{2 0 1 5}$ & $\mathbf{2 0 1 6}$ & $\mathbf{2 0 1 7}$ & $\mathbf{2 0 1 8}$ \\
\hline Uzhgorod city & 85,40 & 391,63 & 534,73 & 538,03 & 681,76 \\
\hline \multicolumn{7}{|c|}{ Districts } \\
\hline Mukachevo & 101,11 & 108,73 & 73,75 & 8,68 & 2,21 \\
\hline Rakhiv & 158,41 & 66,45 & 46,73 & 23,24 & 23,33 \\
\hline Svalyavsky & 739,81 & 167,67 & 1814,51 & 1372,40 & 682,51 \\
\hline Tyachivsky & 250,79 & 332,68 & 717,77 & 1974,57 & 1615,55 \\
\hline Uzhgorod & 109,88 & 113,36 & 798,58 & 196,96 & 208,42 \\
\hline Khust & 55,60 & 61,86 & 52,12 & 57,21 & 21,48 \\
\hline All over the region & 166,47 & 219,24 & 366,12 & 441,46 & 371,11 \\
\hline
\end{tabular}

According to the data in table. 5 shows that the period of the study the incidence rate of adult population of the periodontal disease increased 2.23 times and amounted to 371.11 per 10 thousand population. Thus the marginal difference of the indicator in the section of administrative territories of the region fluctuates 731.0 times: from 2.21 in Mukachevo to 1615.55 in Tyachiv district. In the Tyachiv district this indicator increased 6.44 times during the study period: from 250.79 in 2014 to 1615.55 in 2018. 
Further, in table. 6 presents the study data on the incidence rates of the adult population of the region for diseases of the oral mucosa.

Table 6

The incidence of adult population of the region for diseases of the oral mucosa with the largest and smallest indicators in the section of administrative territories (per 10 thousand adult population), 2014-2018

\begin{tabular}{|c|c|c|c|c|c|}
\hline Administrative territory & $\mathbf{2 0 1 4}$ & $\mathbf{2 0 1 5}$ & $\mathbf{2 0 1 6}$ & $\mathbf{2 0 1 7}$ & $\mathbf{2 0 1 8}$ \\
\hline Uzhgorod city & 43,89 & 29,73 & 55,82 & 76,61 & 139,05 \\
\hline \multicolumn{5}{|c|}{ Districts } \\
\hline Beregovsky & 8,15 & 2,84 & 4,39 & 7,47 & 12,25 \\
\hline Mukachevo & 31,80 & 15,78 & 10,23 & 2,13 & 3,18 \\
\hline Rakhiv & 59,70 & 10,25 & 10,11 & 8,33 & 12,39 \\
\hline Svalyavsky & 96,03 & 103,02 & 311,00 & 1029,54 & 1306,33 \\
\hline Uzhgorod & 42,98 & 49,04 & 639,99 & 178,22 & 111,47 \\
\hline Khust & 4,80 & 10,31 & 27,08 & 77,17 & 10,23 \\
\hline All over the region & 45,42 & 49,54 & 90,88 & 97,79 & 99,83 \\
\hline
\end{tabular}

The analysis given in the table. 6 data on the incidence of diseases of the oral mucous membrane of the adult population of the region indicate that over the study period this indicator increased by 2.19 times and amounted to 99.83 per 10 thousand adult population (Ukraine 82.4). In the context of the administrative territories of the region, as in the analysis of other pathologies, significant statistical differences in the incidence rate of the adult population of diseases of the oral mucosa were revealed. So, its marginal difference is 410.79 times from 3.18 in Mukachevo to 1306.33 in Savelovsky district. When conducting an analysis of the incidence of the adult population, the Svalyavsky district is of particular interest since it recorded, over the years of research, the incidence rate of the adult population by diseases of the oral mucosa by 13.60 times.

Thus, the analysis indicates a deterioration in dental health in the adult population of Transcarpathian region

\section{Characteristics of the system of providing the population} with dental medical care for adults in the public health sector

At the first stage of the study, the provision of the adult population with the full-time posts of dentists per 10 thousand adults was studied. The study and analysis of this indicator was carried out in the context of the administrative territories of the region. The results are shown in table 7. 
Table 7

Adult availability of full-time positions of dental practitioners (per 10 thousand adults), 2014-2018

\begin{tabular}{|c|c|c|c|c|c|}
\hline Administrative territory & $\mathbf{2 0 1 4}$ & $\mathbf{2 0 1 5}$ & $\mathbf{2 0 1 6}$ & $\mathbf{2 0 1 7}$ & $\mathbf{2 0 1 8}$ \\
\hline Uzhgorod city & 3,21 & 3,06 & 3,08 & 3,11 & 3,23 \\
\hline \multicolumn{7}{|c|}{ Districts } \\
\hline Beregovsky & 3,08 & 3,01 & 3,08 & 3,10 & 3,11 \\
\hline Vinogradovsky & 3,25 & 3,13 & 3,24 & 3,24 & 3,48 \\
\hline Velykyi Bereznyi & 3,37 & 3,62 & 3,63 & 3,64 & 3,67 \\
\hline Volovetsky & 3,44 & 3,19 & 3,19 & 3,19 & 3,21 \\
\hline Irshavsky & 3,96 & 3,87 & 3,94 & 3,93 & 3,92 \\
\hline Mizhhirskyi & 3,50 & 3,23 & 3,24 & 3,24 & 1,32 \\
\hline Mukachevo & 4,08 & 3,70 & 3,00 & 1,15 & 1,02 \\
\hline Perechyn & 2,73 & 2,73 & 2,42 & 2,43 & 2,22 \\
\hline Rakhiv & 3,89 & 3,88 & 3,88 & 3,87 & 3,72 \\
\hline Svalyavsky & 3,79 & 3,68 & 3,69 & 3,69 & 3,70 \\
\hline Tyachivsky & 4,26 & 3,97 & 3,96 & 3,94 & 3,53 \\
\hline Uzhgorod & 2,30 & 2,29 & 2,78 & 2,44 & 2,19 \\
\hline Khust & 3,44 & 3,37 & 3,35 & 3,43 & 1,10 \\
\hline $\begin{array}{c}\text { Institutions of regional } \\
\text { subordination }\end{array}$ & 0,05 & 0,08 & 0,06 & 0,05 & 0,05 \\
\hline All over the region & 3,63 & 3,51 & 3,42 & 3,13 & 2,74 \\
\hline
\end{tabular}

The data in table 7 indicate that during the study period as a whole in the region the security of the adult population in full-time positions of dentists has decreased by 1.32 times and amounted to 2.74 per 10 thousand adult population. In terms of administrative territories of the region, the highest level of reduction of the positions of dental practitioners for the provision of medical care to the adult population was registered in the Mukachevo district in 4,0 times with an indicator of 1,02, in the Mizhhirskyi district in 2,65 times with an indicator of 1,32 and in the Khust district in 3,13 times with a score of 1.10. A statistically insignificant increase in the indicator of the availability of adult population to full-time positions of dentists was registered in the territory of $4(28.57 \%)$ administrative territories.

Further, the issue of staffing of staff positions of dentists for servicing adult population by individuals in the context of the administrative territories of the region was studied. The data obtained are shown in Table 8. 
Table 8

Staffing levels of dentists for serving adults by individuals, 2014-2018 (\%)

\begin{tabular}{|c|c|c|c|c|c|}
\hline Administrative territory & $\mathbf{2 0 1 4}$ & $\mathbf{2 0 1 5}$ & $\mathbf{2 0 1 6}$ & $\mathbf{2 0 1 7}$ & $\mathbf{2 0 1 8}$ \\
\hline Uzhgorod city & 93,22 & 100,00 & 100,00 & 100,00 & 100,00 \\
\hline \multicolumn{5}{|c|}{ Districts } \\
\hline Beregovsky & 94,59 & 95,83 & 94,52 & 94,52 & 49,32 \\
\hline Vinogradovsky & 95,73 & 96,46 & 100,00 & 100,00 & 95,24 \\
\hline Velykyi Bereznyi & 100,00 & 100,00 & 100,00 & 100,00 & 100,00 \\
\hline Volovetsky & 100,00 & 91,67 & 91,67 & 91,67 & 100,00 \\
\hline Irshavsky & 100,00 & 100,00 & 100,00 & 100,00 & 97,50 \\
\hline Mizhhirskyi & 100,00 & 100,00 & 100,00 & 100,00 & 100,00 \\
\hline Mukachevo & 98,73 & 99,07 & 100,00 & 97,01 & 100,00 \\
\hline Perechyn & 92,31 & 92,31 & 95,65 & 95,65 & 95,24 \\
\hline Rakhiv & 100,00 & 98,11 & 99,06 & 96,23 & 96,08 \\
\hline Svalyavsky & 100,00 & 96,72 & 96,72 & 100,00 & 100,00 \\
\hline Tyachivsky & 99,12 & 98,58 & 98,11 & 98,10 & 98,94 \\
\hline Uzhgorod & 100,00 & 100,00 & 88,41 & 96,72 & 100,00 \\
\hline Khust & 100,00 & 100,00 & 100,00 & 100,00 & 95,35 \\
\hline $\begin{array}{c}\text { Institutions of regional } \\
\text { subordination }\end{array}$ & 100,00 & 100,00 & 100,00 & 85,71 & 100,00 \\
\hline All over the region & 98,29 & 98,53 & 98,34 & 98,18 & 94,89 \\
\hline
\end{tabular}

The analysis is given in table. 8 of the data indicates that the level of staffing of full-time positions of dentists for servicing adult population by individuals in the region in the period 2014-2018 decreased by $3.40 \%$ and amounted to $94.89 \%$. In territory $7(50,0 \%)$ of administrative territories ia in establishments of regional subordination the level of staffing of full-time positions of doctors - dentists for service of adult population by individuals is $100 \%$. The lowest level of staffing of natural persons is registered in the Beregovsky district, where it is $49.32 \%$.

The next step was to study the dynamics of the proportion of adults covered by preventive dental examinations for the period 2014-2019, the results of which are shown in table 9.

The analysis is given in table 9 data indicate that during the study period, the proportion of adults covered by preventive dental examinations decreased by $3.56 \%$ to $20.79 \%$ (Ukraine $17.2 \%$ ). At the same time, the share of adult population covered by preventive dental examinations in the context of administrative territories of the region has significant differences and ranges from $1.87 \%$ in the Mukachevo district to $30.18 \%$ in Uzhgorod. The marginal difference of the indicator is 16.14 times. In general, the data obtained indicate that the population is not interested in visiting dentists with a preventive purpose, and on the other hand, that there is no preventive component in the activity of the dental service of the region. 
Table 9

\section{Percentage of adult population covered}

by preventive dental examinations, 2014-2018 (\%)

\begin{tabular}{|c|c|c|c|c|c|}
\hline Administrative territory & $\mathbf{2 0 1 4}$ & $\mathbf{2 0 1 5}$ & $\mathbf{2 0 1 6}$ & $\mathbf{2 0 1 7}$ & $\mathbf{2 0 1 8}$ \\
\hline Uzhgorod city & 17,15 & 23,17 & 23,68 & 26,11 & 30,18 \\
\hline \multicolumn{7}{|c|}{ Districts } \\
\hline Beregovsky & 4,63 & 4,02 & 5,29 & 7,95 & 8,69 \\
\hline Vinogradovsky & 21,14 & 19,27 & 20,43 & 21,33 & 19,45 \\
\hline Velykyi Bereznyi & 22,34 & 14,26 & 13,67 & 13,40 & 14,44 \\
\hline Volovetsky & 15,99 & 19,12 & 18,54 & 12,86 & 8,72 \\
\hline Irshavsky & 31,77 & 30,51 & 31,84 & 30,74 & 28,78 \\
\hline Mizhhirskyi & 37,19 & 38,41 & 48,10 & 34,90 & 24,58 \\
\hline Mukachevo & 14,60 & 8,52 & 13,14 & 1,77 & 1,87 \\
\hline Perechyn & 12,22 & 14,77 & 10,59 & 12,37 & 22,18 \\
\hline Rakhiv & 20,15 & 48,65 & 47,65 & 45,76 & 46,67 \\
\hline Svalyavsky & 1,38 & 10,32 & 10,36 & 12,21 & 10,38 \\
\hline Tyachivsky & 38,58 & 34,38 & 20,63 & 20,55 & 18,05 \\
\hline Uzhgorod & 44,37 & 47,68 & 37,50 & 34,26 & 37,64 \\
\hline Khust & 29,45 & 15,12 & 14,41 & 16,24 & 15,99 \\
\hline All over the region & 24,35 & 24,59 & 23,02 & 21,04 & 20,79 \\
\hline
\end{tabular}

A logical continuation of the study was the study of the proportion of the adult population requiring the results of preventive examinations of sanitation of the oral cavity. The data obtained are given in table 10 .

Table 10

The proportion of the adult population requiring oral sanitation, 2014-2018 (\% of those examined)

\begin{tabular}{|c|c|c|c|c|c|}
\hline Administrative territory & $\mathbf{2 0 1 4}$ & $\mathbf{2 0 1 5}$ & $\mathbf{2 0 1 6}$ & $\mathbf{2 0 1 7}$ & $\mathbf{2 0 1 8}$ \\
\hline Uzhgorod city & 89,56 & 86,42 & 84,72 & 79,45 & 70,87 \\
\hline \multicolumn{7}{|c|}{ Districts } \\
\hline Beregovsky & 37,14 & 48,50 & 69,49 & 75,23 & 67,30 \\
\hline Vinogradovsky & 59,38 & 62,50 & 57,44 & 60,56 & 58,18 \\
\hline Velykyi Bereznyi & 67,24 & 71,83 & 71,22 & 72,94 & 71,83 \\
\hline Volovetsky & 59,43 & 57,95 & 50,50 & 38,41 & 37,68 \\
\hline Irshavsky & 72,40 & 71,74 & 74,77 & 73,30 & 75,29 \\
\hline Mizhhirskyi & 78,82 & 85,01 & 72,74 & 89,25 & 70,92 \\
\hline Mukachevo & 88,57 & 8,26 & 88,54 & 91,49 & 100,00 \\
\hline Perechyn & 55,92 & 52,79 & 60,43 & 64,87 & 66,89 \\
\hline Rakhiv & 72,13 & 45,16 & 49,41 & 51,65 & 53,96 \\
\hline Svalyavsky & 102,61 & 54,16 & 93,65 & 38,83 & 54,16 \\
\hline Tyachivsky & 85,50 & 83,04 & 91,00 & 91,18 & 95,04 \\
\hline Uzhgorod & 93,98 & 90,73 & 92,90 & 90,72 & 83,59 \\
\hline Khust & 95,00 & 91,97 & 86,67 & 79,62 & 82,74 \\
\hline All over the region & 82,10 & 192,79 & 89,09 & 89,92 & 89,79 \\
\hline
\end{tabular}


It was found that the proportion of adults who, as a result of preventive examinations, required remediation as a whole in the region increased by $7.69 \%$ and amounted to $89.79 \%$ of the number of surveyed (Ukraine $55.4 \%$ ). In terms of administrative territories of the region, this indicator ranged from $37.68 \%$ in the Volovetsky district to $100 \%$ in the Mukachevo district. The marginal difference of the indicator is 2.65 times.

In order to study the effectiveness of dental preventive examinations, the proportion of the adult population was further examined by the results of the prophylactic examination, which, according to the testimony, was the rehabilitation of the oral cavity. The data obtained are shown in Table 11.

Table 11

The proportion of the adult population who underwent rehabilitation of the oral cavity, 2014-2018 (\% of those in need)

\begin{tabular}{|c|c|c|c|c|c|}
\hline Administrative territory & $\mathbf{2 0 1 4}$ & $\mathbf{2 0 1 5}$ & $\mathbf{2 0 1 6}$ & $\mathbf{2 0 1 7}$ & $\mathbf{2 0 1 8}$ \\
\hline Uzhgorod city & 78,89 & 80,73 & 82,42 & 95,95 & 93,05 \\
\hline \multicolumn{7}{|c|}{ Districts } \\
\hline Beregovsky & 92,26 & 90,31 & 83,74 & 72,26 & 81,95 \\
\hline Vinogradovsky & 95,18 & 95,73 & 92,54 & 93,41 & 94,73 \\
\hline Velykyi Bereznyi & 73,27 & 81,09 & 82,16 & 84,92 & 81,09 \\
\hline Volovetsky & 86,47 & 82,25 & 81,44 & 95,47 & 83,25 \\
\hline Irshavsky & 80,23 & 82,67 & 83,63 & 82,70 & 85,09 \\
\hline Mizhhirskyi & 73,78 & 73,38 & 71,99 & 67,21 & 100,00 \\
\hline Mukachevo & 94,54 & 100,0 & 91,04 & 86,54 & 87,19 \\
\hline Perechyn & 60,55 & 60,95 & 63,57 & 75,89 & 61,12 \\
\hline Rakhiv & 74,22 & 85,00 & 86,34 & 77,78 & 75,91 \\
\hline Svalyavsky & 94,91 & 91,76 & 65,29 & 98,93 & 78,81 \\
\hline Tyachivsky & 88,17 & 87,69 & 95,00 & 94,71 & 94,45 \\
\hline Uzhgorod & 96,61 & 95,83 & 93,24 & 91,15 & 87,86 \\
\hline Khust & 83,96 & 92,05 & 89,12 & 84,31 & 80,36 \\
\hline All over the region & 84,99 & 85,76 & 82,86 & 85,10 & 81,07 \\
\hline
\end{tabular}

Obtained in the course of the study and given in table 11 data indicate that the proportion of adults from the needy, who, according to the results of a preventive examination, performed oral remediation in the years of the study (2014-2918) in the region decreased by $3.92 \%$ and amounted to 81 , $07 \%$. The decrease in the proportion of the population that underwent oral cavity repair in the years of the study decreased in 7 (50.0\%) administrative territories and the proportion of the corresponding adult population also increased in $7(50.0 \%)$ administrative territories of the region. The lowest proportion of the population who underwent oral remediation was registered in the Perechyn district $-61.12 \%$. 
An important indicator of the activity of the dental service is the indicator of the public's appeal to dentists. We studied the indicator of the population of the Transcarpathian region to the dentists in the dynamics of 2014-2018, per 10 thousand adults. The results obtained are shown in table 12 .

Table 12

The appeal of the adult population to dentists, 2014-2018 (per 10 thousand adults)

\begin{tabular}{|c|c|c|c|c|c|}
\hline Administrative territory & $\mathbf{2 0 1 4}$ & $\mathbf{2 0 1 5}$ & $\mathbf{2 0 1 6}$ & $\mathbf{2 0 1 7}$ & $\mathbf{2 0 1 8}$ \\
\hline Uzhgorod city & 4412,76 & 4224,83 & 4412,75 & 4714,44 & 5399,75 \\
\hline \multicolumn{7}{|c|}{ Districts } \\
\hline Beregovsky & 6888,76 & 5947,55 & 6846,67 & 6564,98 & 6033,19 \\
\hline Vinogradovsky & 8144,16 & 7471,00 & 7882,95 & 7919,91 & 7205,79 \\
\hline Velykyi Bereznyi & 9110,13 & 6807,82 & 7091,00 & 6633,06 & 6894,38 \\
\hline Volovetsky & 8544,60 & 8838,92 & 8517,00 & 8051,62 & 6836,99 \\
\hline Irshavsky & 11978,38 & 11602,71 & 11668,20 & 11210,84 & 9998,56 \\
\hline Mizhhirskyi & 7735,97 & 7753,03 & 8224,70 & 7748,55 & 5368,09 \\
\hline Mukachevo & 9716,64 & 6985,04 & 5694,07 & 2102,66 & 1742,34 \\
\hline Perechyn & 6809,83 & 6547,52 & 6635,75 & 5377,11 & 6718,14 \\
\hline Rakhiv & 7491,86 & 7545,52 & 7267,07 & 7873,28 & 8001,31 \\
\hline Svalyavsky & 8743,95 & 8194,93 & 7866,99 & 7586,92 & 7365,51 \\
\hline Tyachivsky & 5203,57 & 4721,73 & 7870,70 & 7820,67 & 5569,61 \\
\hline Uzhgorod & 8401,74 & 8324,01 & 6870,55 & 5982,87 & 6028,54 \\
\hline Khust & 6846,26 & 8280,93 & 7770,59 & 7689,18 & 4714,87 \\
\hline All over the region & 7800,08 & 7286,63 & 7463,20 & 6787,95 & 5911,84 \\
\hline
\end{tabular}

The analysis of the data presented in Table 12 indicates a decrease in the indicator of adult treatment of dentists in terms of 10 thousand adults in the years of the study by 1.32 times with the level of 5911.84 (Ukraine 7000). At the same time, the decrease in the rate of referral of adult population to dentists was registered in the territory of 10 (71.4\%) administrative territories. It should be noted that this indicator has statistically significant differences in the section of administrative territories of the region. Thus, the marginal difference in the rate of adult treatment of dentists is 5.74 times: from 1742.34 in Mukachevo to 9998.56 in the Irshava district.

Further, in table 13 presents the results of the study on the number of primary referrals of adults to dentists in terms of 10 thousand adults for the period 2014-2018. 
Table 13

Number of primary referrals of adults to dentists, 2014-2018 (per 10 thousand adults)

\begin{tabular}{|c|c|c|c|c|c|}
\hline Administrative territory & $\mathbf{2 0 1 4}$ & $\mathbf{2 0 1 5}$ & $\mathbf{2 0 1 6}$ & $\mathbf{2 0 1 7}$ & $\mathbf{2 0 1 8}$ \\
\hline Uzhgorod city & 1715,45 & 2316,76 & 2368,24 & 2610,97 & 3017,51 \\
\hline \multicolumn{7}{|c|}{ Districts } \\
\hline Beregovsky & 3437,15 & 3110,91 & 3493,08 & 2706,99 & 2432,78 \\
\hline Vinogradovsky & 6292,98 & 5805,78 & 4054,93 & 5958,08 & 5641,49 \\
\hline Velykyi Bereznyi & 4868,30 & 3766,78 & 4244,92 & 3835,68 & 2969,68 \\
\hline Volovetsky & 7392,87 & 3408,83 & 2459,62 & 4557,74 & 3033,14 \\
\hline Irshavsky & 6457,41 & 6315,87 & 6488,12 & 6408,46 & 5750,23 \\
\hline Mizhhirskyi & 4884,52 & 3579,48 & 4521,92 & 3490,48 & 2291,53 \\
\hline Mukachevo & 4155,94 & 3238,53 & 2872,20 & 848,80 & 722,08 \\
\hline Perechyn & 2886,47 & 1858,28 & 3713,32 & 1925,25 & 2428,69 \\
\hline Rakhiv & 4151,34 & 4864,75 & 4727,95 & 4562,85 & 4763,81 \\
\hline Svalyavsky & 3815,07 & 4095,54 & 4140,02 & 4853,27 & 4785,35 \\
\hline Tyachivsky & 4780,51 & 4235,54 & 4070,97 & 4123,39 & 4033,39 \\
\hline Uzhgorod & 4437,19 & 4768,29 & 3817,10 & 3482,95 & 3764,15 \\
\hline Khust & 4141,73 & 3988,77 & 3790,93 & 4318,29 & 3040,60 \\
\hline All over the region & 4490,04 & 4194,33 & 3952,64 & 3801,21 & 3532,23 \\
\hline
\end{tabular}

According to the results obtained during the study on the table. 13 data show that the number of primary appeals to the adult dentists for the period of the study decreased by 1.27 times and amounted to 3532.23 per 10 thousand adults, which is $59.75 \%$ of all appeals to the population for dental care (Ukraine 33,3\%). During the study period, the number of primary referrals of adults to dentists per 10 thousand adults decreased by 11 (\%) administrative territories of the region. In the context of administrative territories, this indicator differs 7.96 times: from 722.08 in Mukachevo district to 5750.23 in Irshava district.

The next step of the study was to study and analyze the function of the position of dentists, providing outpatient medical care to adults in terms of occupied position for the period 2014-2018. The results are shown in table 14. 
Table 14

Function of the position of dental practitioners providing outpatient medical care to adults, 2014-2018 (in terms of occupied position)

\begin{tabular}{|c|c|c|c|c|c|}
\hline Administrative territory & $\mathbf{2 0 1 4}$ & $\mathbf{2 0 1 5}$ & $\mathbf{2 0 1 6}$ & $\mathbf{2 0 1 7}$ & $\mathbf{2 0 1 8}$ \\
\hline Uzhgorod city & 1476,91 & 1380,46 & 1434,14 & 1516,54 & 1669,83 \\
\hline \multicolumn{5}{|c|}{ Districts } \\
\hline Beregovsky & 2367,37 & 2064,23 & 2350,49 & 2243,13 & 3939,00 \\
\hline Vinogradovsky & 2620,96 & 2477,36 & 2433,61 & 2447,73 & 2172,07 \\
\hline Velykyi Bereznyi & 2702,71 & 1879,87 & 1953,33 & 1824,53 & 1879,87 \\
\hline Volovetsky & 2484,77 & 3022,91 & 2914,36 & 2750,73 & 2132,00 \\
\hline Irshavsky & 3028,13 & 2994,68 & 2963,33 & 2853,53 & 2613,98 \\
\hline Mizhhirskyi & 2209,33 & 2399,15 & 2538,81 & 2389,19 & 4072,63 \\
\hline Mukachevo & 2413,23 & 1903,20 & 1895,25 & 1879,32 & 1708,20 \\
\hline Perechyn & 2698,17 & 2595,00 & 2861,82 & 2315,09 & 3184,40 \\
\hline Rakhiv & 1927,47 & 1982,73 & 1889,71 & 2112,51 & 2240,04 \\
\hline Svalyavsky & 2306,79 & 2302,92 & 2205,42 & 2054,69 & 1991,34 \\
\hline Tyachivsky & 1232,39 & 1207,41 & 2023,98 & 2020,83 & 1594,99 \\
\hline Uzhgorod & 3648,77 & 3632,77 & 2798,23 & 2533,08 & 2749,45 \\
\hline Khust & 1988,30 & 2458,18 & 2321,92 & 2242,72 & 4497,76 \\
\hline $\begin{array}{c}\text { Institutions of regional } \\
\text { subordination }\end{array}$ & 2417,56 & 2136,77 & 2590,18 & 3004,22 & 2549,80 \\
\hline All over the region & 2185,90 & 2107,62 & 2216,30 & 2208,64 & 2270,48 \\
\hline
\end{tabular}

According to the data in table 14. As a whole, in the region, the function of the position of dental practitioners providing outpatient medical care to the adult population increased by 84.58 medical procedures and amounted to 2270.48 in terms of the occupied position. The greatest increase in the function of the post was registered in Khust district - 2.3 times with the level of 4497.76. The decrease in the function of the post was registered in the territory of $7(50.0 \%)$ territories, and its increase in the territory of $7(50.0 \%)$ of administrative territories.

\section{CONCLUSIONS}

Analysis of dental health indicators of adults in the Transcarpathian region revealed its deterioration over the 2014-2018 period. During the study period, the incidence of both the incidence of the adult population and the prevalence of dental diseases among him. At the same time, the organization and delivery of specialized medical care in the public health sector tend to deteriorate.

\section{SUMMARY}

The conducted analysis of dental health indicators of adult population of Transcarpathian region showed its deterioration for the period 2014-2018. 
Thus, the incidence rates of adult population for dental caries increased by 1.06 times and amounted to 7207.73 , for periodontal disease increased by 2.23 times and amounted to 371.11 , for diseases of the oral mucosa indicates that during the study period specified the figure increased by 2.19 times and amounted to 99.83 per 10 thousand adults with a national figure of 82.4. Prevalence rates among adults among the adult population of dental caries increased 1.35 times and amounted to 20405.60, periodontal disease increased 2.83 times and amounted to 1050.65 , diseases of the oral mucosa increased 2.79 times and amounted to 282, 63 per 10 thousand adult population of the region. The incidence rates of the adult population of the Transcarpathian region and the prevalence of dental diseases studied in the cross section of administrative territories have significant statistical differences.

The analysis of the provision of specialized medical care to the public in the public health sector showed its deterioration, including the reduction: the provision of adult population to full-time positions of dentists by 1.32 times with a level of 2.74 per 10 thousand adults, completeness. staff positions of dentists to serve adults by individuals by $3.40 \%$ with a level of $94.89 \%$, coverage by preventive dental examinations by $3.56 \%$ with a level of $20.79 \%$, the proportion of adults in need, as According to the results of the prophylactic examination, the oral cavity was rehabilitated by $3.92 \%$ with the level of $81.07 \%$, the appeal of the adult population to dentists was 1.32 times in terms of 10 thousand with the level of 5911.84. There are statistically significant differences in the level of security of the adult population of the Transcarpathian region with the positions of dental practitioners and the indicators of the activity investigated by administrative territories.

The results obtained should be taken into account in the process of reforming the system of health care delivery to the population of the region.

\section{REFERENCES}

1. Department of Health Statistics and Informatics, World Health Organization Information, Evidence and Research Group (2013) My'rovaya staty`sty $k a 2013$ [World Statistics 2013], Department of Health Statistics and Informatics, World Health Organization Information, Evidence and Research Group. Retrieved from: http://www.who.int/gho/publications/ world_health_statistics/2013/en /index.html. (accessed 18 November 2019)

2. European Series on Health for All (2005) Osnovy politiki dostizheniya zdorovya dlya vseh v Evropejskom regione VOZ [Health for All Policy Framework for the WHO European Region]. European Series on 
Health for All (electronic journal) no. 7, 98 pp. Retrieved from: http://www.euro.who.int/ru/publications/abstracts/health21-the-health-forall-policy-framework-for-the-who-european-region (accessed 17 November 2019)

3. FDI General Assembly (2003) Zayavlenie mezhdunarodnoj stomatologicheskoj associacii (FDI) «Globalnye celi v oblasti stomatologicheskogo zdorovya (Sovmestnoe zayavlenie FDI - VOZ IADR)» [Statement of the International Dental Association (FDI) «Global Dental Health Goals (Joint Statement of FDI-WHO-IADR)»]. FDI General Assembly. Retrieved from: http://www.e-stomatology.ru/star/ info/fdi/fdi_global. Htm (accessed 14 November 2019)

4. PII Vsemirnaya stomatologicheskaya federaciya [FDI World Dental Federation] Retrieved from:https://www.fdiworlddental.org/ (accessed 17 November 2019)

5. Vahnenko O. M. (2011) Analiz resursnogo zabezpechennya stomatologichnoyi sluzhbi v Ukrayini [Analyze of resource care of dental service in Ukraine]. Modern dentistry,no. 3, pp.172-176.

6. Yu.V.Voronenko, O.V.Pavlenko, I.P.Mazur (2018) Stomatologichna dopomoga v Ukrayini: osnovni pokazniki diyalnosti za 2008-2018 roki [Dental auxiliaries in Ukraine: the main displays of activity in 2008-2018: pre-historic]. Kropivnitsky: Polium. (in Ukrainian)

7. Kostlan Ya. (1982) Stomatologicheskoe obsluzhivanie v Evrope [Dental care in Europe] World Health Organization. European Regional Office. Copenhagen.

8. Pro vnesennya zmin do deyakih zakonodavchih aktiv Ukrayini shodo udoskonalennya zakonodavstva $\mathrm{z}$ pitan diyalnosti zakladiv ohoroni zdorov'ya [On Introduction of Wetlands to the Actual Legislative Acts of Ukraine on Food and Nutrition Legislation on Health Protection]: Zakon Ukrayini vid 06.04.2017 r. № 2002 [Law of Ukraine no. 2002 of 06.04.2017]. Retrieved from: http://www.ukrainepravo.com/lawmaking/bill_passed_by_legislature/zakon-ukraini-pro-vnesennya-zmin-dodeyakikh-zakonodavchikh-aktiv-ukraini-shchodo-udoskonalennya-zak/ (accessed 15 November 2019)

9. Pro derzhavni finansovi garantiyi medichnogo obslugovuvannya naselennya [On Holders of Financial Guarantees for Medical Services to the Population]: Zakon Ukrayini vid 19 zhovtnya 2017 roku № 2168-VIII [Law of Ukraine No. 2168-VIII of June 19, 2017]. Retrieved from: http://search.ligazakon.ua/1_doc2.nsf/link1/T172168.html (accessed 14 November 2019) 
10. Pro zatverdzhennya Poryadku realizaciyi derzhavnih garantij medichnogo obslugovuvannya naselennya za programoyu medichnih garantij dlya pervinnoyi medichnoyi dopomogi na 2018 rik [On Approval of the Procedure for Realization of the Realization of the Population's Healthcare Guarantees for the Program of Medical Guarantees for Primary Medical Assistance for 2018]: Postanova KMU vid 25.04.2018 r. № 407 [Resolution of the Cabinet of Ministers of Ukraine No. 407 dated 25.04.2018]. Retrieved from: https://www.apteka.ua/article/458646 (accessed 13 November 2019)

11. Osnovi zakonodavstva Ukrayini pro ohoronu zdorov'ya [On Healthy Hunting Legislation of Ukraine]: Zakon Ukrayini vid 19 listopada 1992 roku № 2801-XII [Law of Ukraine No. 2801-XII of November 19, 1992]. Retrieved from: https://zakon.rada.gov.ua/laws/show/2801-12 (accessed 17 November 2019)

12. Transcarpathian Regional Medical Information and Analytical Center (2015) Merezha zakladiv ta osnovni pokazniki diyalnosti sistemi ohoroni zdorov'ya Zakarpatskoyi oblasti za 2014 rik [The extent of laying and the main indicators of health care system of Transcarpathian region in 2014]. Uzhgorod: Transcarpathian Regional Medical Information and Analytical Center (in Ukrainian)

13. Transcarpathian Regional Medical Information and Analytical Center (2016) Merezha zakladiv ta osnovni pokazniki diyalnosti sistemi ohoroni zdorov'ya Zakarpatskoyi oblasti za 2015 rik [The extent of laying and the main indicators of health care system of Transcarpathian region in 2015]. Uzhgorod: Transcarpathian Regional Medical Information and Analytical Center (in Ukrainian)

14. Transcarpathian Regional Medical Information and Analytical Center (2017) Merezha zakladiv ta osnovni pokazniki diyalnosti sistemi ohoroni zdorov'ya Zakarpatskoyi oblasti za 2016 rik [The extent of laying and the main indicators of health care system of Transcarpathian region in 2016]. Uzhgorod: Transcarpathian Regional Medical Information and Analytical Center (in Ukrainian)

15. Transcarpathian Regional Medical Information and Analytical Center (2018) Merezha zakladiv ta osnovni pokazniki diyalnosti sistemi ohoroni zdorov'ya Zakarpatskoyi oblasti za 2017 rik [The extent of laying and the main indicators of health care system of Transcarpathian region in 2017]. Uzhgorod: Transcarpathian Regional Medical Information and Analytical Center (in Ukrainian)

16. Transcarpathian Regional Medical Information and Analytical Center (2019) Merezha zakladiv ta osnovni pokazniki diyalnosti sistemi 
ohoroni zdorov'ya Zakarpatskoyi oblasti za 2018 rik [The extent of laying and the main indicators of health care system of Transcarpathian region in 2018]. Uzhgorod: Transcarpathian Regional Medical Information and Analytical Center (in Ukrainian)

Information about the author: Pyshkivtsi A.-M. M., orcid.org/0000-0002-6478-1948 Postgraduate student of the Department of Health Sciences

Uzhhorod National University 29, Mytna str., 88000, Uzhhorod, Ukraine 


\title{
RECEIVING AND MAINTAINING HEALTH WORKFORSE RESOURSES IN WHO STRATEGIC DOCUMENTS
}

\author{
Keretsman A. O.
}

\section{INTRODUCTION}

Health workforces in medical care play a key role in the organization and delivery of health care worldwide. The ability of health systems to function effectively and respond adequately to new challenges depends to a large extent on the availability of a sufficient number of health workers with the necessary skills and working where they are needed, in an environment conducive to their motivation and involvement ${ }^{1}$.

With the collapse of the USSR, the economic crisis, low wages and unsatisfactory social conditions, which were observed in almost all countries of the post-Soviet space in the 1990s, significantly increased opportunities for labour migration ${ }^{2}$. Although migration of skilled workers is increasing in a number of sectors ${ }^{3}$, the significant increase in migration of health-care workers in recent years poses a number of specific policy issues to countries, becoming a sphere of special international attention due to its negative consequences. In particular, the negative effects of the migration of health care workers on developing countries' health systems were highlighted in 2006 in the World Health Report $2006^{4}$.

${ }^{1}$ Kadrovye resursy zdravoohraneniya [Health workforce] // Euro: website. Retrieved from: http://www.euro.who.int/ru/health-topics/Health-systems/health-workforce/health-workforce (accessed 15 November 2019).

${ }^{2}$ Migraciya rabotnikov zdravoohraneniya [Migration of health workers]. WHO: website. Retrieved from: http://www.who.int/mediacentre/factsheets/fs301/ru/index.html (accessed 18 November 2019).

3 Findlay A, Lowell L. (2002) Migratsiia vysokokvalifitsirovannykh spetsialistov iz razvivaiushchikhsia stran: vozdeistvie i otvetnye mery na urovne politiki. [Migration of highly skilled persons from developing countries: impact and policy responses]. International Labour Organization, Dokumenty po mezhdunarodnoi migratsii [International Labour Organization, International Migration Papers]. Geneva, no. 43.

${ }^{4}$ Vsemirnyj doklad ob ohrane zdorovya 2006 goda - sovmestnaya rabota $\mathrm{v}$ interesah ohrany zdorovya [The world health report 2006 - working together for health. Geneva, World Health Organization]. , WHO: website. Retrieved from: http://www.who.int/whr/2006/en/ (accessed 13 November 2019 ). 
International recruitment and migration of health workers remains an important issue on the global health agenda from the early 1990s to the present days ${ }^{5,6}$. The outflow of qualified medical personnel from the country and domestically into other sectors of the economy is recognized as one of the main obstacles that hinders the development of modern healthcare systems ${ }^{7}$. At the same time, the crisis state of health personnel is a universal problem, from which no country is immune.

As a result of decades of underinvestment in the training of health workers, their retraining, wages, working conditions and management, a chronic shortage of health care system workers has been worsening, leading to acute shortages of key professionals, increasing rates of change in occupation and early retirement, as well as national and international migration $^{8}$. So, with the current estimates, currently in the world the approximate shortage of doctors, midwives, nurses, pharmacists, dentists and other staff is more than 7.2 million people. At the same time, the personnel cadre concerns not only practical health workers, but also extends to teachers and instructors, supervisors, and support staff. Inadequate distribution of resources, inefficient use of knowledge or neglect of knowledge, as well as migration, as WHO experts predict, without effective intervention can lead to a shortage of 18 million health workers in the future ${ }^{9}$.

At the same time, it is difficult for most countries to adequately allocate the available Health workforce resources, and the ease with which healthcare

${ }^{5}$ Razvitie medicinskih kadrov [Medical personnel development]. WHO: website. Retrieved from: http://whodc.mednet.ru/ru/component/attachments/download/20.html (accessed 13 November 2019).

${ }^{6}$ Kajgoroda T. V. (2019) Kadrovye resursy zdravoohraneniya [Health personnel resources]. Socialnye aspekty zdorovya naseleniya (electronic journal), vol.3, no 67. Retrieved from: http://vestnik.mednet.ru/content/view/1081/30/lang,ru_ru.cp1251. (accessed 12 November 2019)

7 Wismar M., Maier C.B., Glinos I.A., Dussault G., Figueras J. (2011) Mobilnost medicinskikh rabotnikov i sistemy zdravookhraneniya. Fakticheskie dannye iz 17 stran [Health professional mobility and health systems. Evidence from 17 European countries]. Evropeiskoe regionalnoe biuro VOZ [WHO Regional Office for Europe] . Copenhagen, 597 pp.

${ }^{8}$ Vseobshaya realnost: bez trudovyh resursov net zdoroCopenhagenvya [A Universal Truth: No health without a workforce]. WHO: website. Retrieved from: http://www.who.int/workforcealliance/knowledge/resources/hrhreport2013/ en/index.html (accessed 11 November 2019)

${ }^{9}$ G. Dussault, J. Buchan, W. Sermeus, Z. Padaiga. Ocenka budushih potrebnostej v kadrovyh resursah zdravoohraneniya [Assessment of future health workforce needs]. Euro: website. Retrieved from: http://www.euro.who.int/_data/assets/pdf_file/0018/133038/ e94295R.pdf (accessed 13 November 2019) 
providers move from one country to another complicates planning at the national level, in particular due to poor accounting for migration flows. ${ }^{10}$.

Given that in the overwhelming majority of countries of the world there is no explicitly defined strategy for the development of human resources of the Health Departmens, scientists increasingly recognize the need to develop methods and means of maintaining and attracting medical personnel to achieve the Sustainable Development Goals and create fair primary health care systems, which will make health services are more affordable, efficient and rational ${ }^{11}$.

In view of this, we consider it necessary to analyze the WHO strategic documents on retention and involvement of health care workers, which will facilitate the development of concrete measures to address migration at national and regional levels.

\section{Migration of medical personnel and ways to solve it in WHO documents}

Different types of migration flows can have different triggers, different effects and have different consequences for the policies of exporting and importing countries. This is determined by its duration (may be temporary or permanent) and depends on whether the migration of workers is voluntary or forced. Often, it can be provoked by various circumstances in the country of destination or, from the country of which it is carried out, and be a symptom of deep problems of the health systems themselves (for example, problems of maintaining medical professionals or improving human resources planning $)^{12}$. But, most often, the international migration of health workers is seen as an elementary one-way "brain drain", as a result of which health systems in countries lose trained personnel. As a result of external migration, they suffer from staff shortages, low morale and poor quality, insufficient medical services and limited access to them. In most countries, there is also a movement from the public sector to the private, especially in the case of a

10 Rukovodstvo po monitoringu i otsenke kadrovykh resursov zdravookhraneniia (spetsialno dlia stran s nizkim i srednim urovnem dokhoda) [Guidance on monitoring and evaluation of the health workforce (specifically for low- and middle-income countries)] Evropeiskoe regionalnoe biuro VOZ [WHO Regional Office for Europe] . Copenhagen, 188 pp.

11 Dokument A72/24 Semdesiat vtoroi sessii Vsemirnoi assamblei zdravookhraneniia [Document A72/24 Seventy-second World Health Assembly]. Retrieved from: http://apps.who.int/gb/ebwha/pdf_files/WHA72/A72_24-ru.pdf. (accessed 11 November 2019).

12 Stilwell B et al. (2003) Razrabotka osnovannoi na fakticheskikh dannykh eticheskoi politiki $v$ otnoshenii migratsii meditsinskikh rabotnikov: kontseptualnye $i$ prakticheskie problemy [Developing evidence based ethical policies on the migration of health workers: conceptual and practical challenges]. Liudskie resursy dlia zdravookhraneniia. 
significant difference in income levels ${ }^{13,14}$. At the same time, migration is determined by the individual's right to act in their own interests, taking into account various personal motives ${ }^{15}$, different approaches of governments to managing the migration of medical workers and the intermediary role of recruitment agencies ${ }^{16}$. The frequent lack of evidence on the migration of medical workers ${ }^{17}$ and the lack of universal international standards and documents that could be used to compare migration levels between countries according to common criteria only complicates the development of practical measures for a single human resources planning and management strategy ${ }^{18}$.

On the basis of a comprehensive discussion at the Third Global Forum ${ }^{19}$ recommendations were adopted to fill the shortage of workers in an era of universal coverage of health services. Key recommendations include:

1. Strengthening political and technical leadership in countries to support long-term health workforse resource development efforts.

${ }^{13}$ Dumont J, Zurn P. (2007) Meditsinskie rabotniki-immigranty v stranakh OESR v bolee shirokom kontekste vysokokvalifitsirovannoi migratsii [Immigrant health workers in OECD countries in the broader context of highly skilled migration]. SOPEMI Ed. Perspektivy mezhdunarodnoi migratsii. Organizatsiia ekonomicheskogo sotrudnichestva i razvitiia. [SOPEMI ed. International migration outlook. Organisation for Economic Co-operation and Development]. Parish.

${ }^{14}$ Robinson R. (2007) Zatraty i vygody migracii medicinskih rabotnikov iz Vostochnoj i Yuzhnoj Afriki (VYuA) [The costs and benefits of health worker migration from East and Southern Africa (ESA]). Literature review. Harare, EQUINET, 2007 (EQUINET Discussion Paper 49; Retrieved from: http://www.equinetafrica.org/bibl/docs/DIS49HR.robinson.pdf (accessed 14 November 2019).

${ }^{15}$ Bueno de Mesquita J, Gordon M. (2005) Mezhdunarodnaya migraciya medicinskih rabotnikov: analiz soblyudeniya prav cheloveka [The international migration of health workers: a human rights analysis]. Medact, (electronic journal). Retrieved from: http://www.medact.org/ content/Skills\%20drain/Bueno\%20de\%20Mesquita\%20and\%20Gordon.pdf (accessed 10 November 2019).

${ }^{16}$ Buchan J, Perfilieva P. Migraciya medicinskih rabotnikov v Evropejskom regione: tematicheskie issledovaniya po stranam i politicheskie posledstviya. [Health worker migration in the European Region:country case studies and policy implications]. Euro: website. Retrieved from: http://www.euro.who.int/document/e88366.pdf (accessed 10 November 2019).

17 Diallo K. (2004) Dannye o migratsii meditsinskikh rabotnikov: istochniki, vidy ispolzovaniia i problemy [Data on the migration of health-care workers: sources, uses, and challenges].Bulletin of the World Health Organization, 82:559-636.

${ }^{18}$ Auriol L, Sexton J. (2002) Liudskie resursy v oblasti nauki i tekhnologii: voprosy izmereniia i mezhdunarodnaia mobilnost [Human resources in science and technology:measurement issues and international mobility] Organizatsiia ekonomicheskogo sotrudnichestva i razvitiia [Organisation for Economic Co-operation and Development]. Paris: pp. 13-39.

19 Tretii globalnyi forum po kadrovym resursam zdravookhraneniia (2013) Kadrovye resursy zdravookhraneniia: osnova dlia obespecheniia vseobshchego okhvata medikosanitarnymi uslugami i povestka dnia v oblasti razvitiia na period posle 2015 goda [Human resources for health: a framework for universal health coverage and the post-2015 development agenda]. Recife, Brazil. 
2. Gathering reliable data and enhancing health workforse resources for health databases.

3. Maximize the role of mid-level and individual communities to improve the accessibility and affordability of primary care services.

4. Retention of health workers in the countries with the most severe shortage of these resources and more balanced geographical distribution.

5. Provide mechanisms that provide for the rights and responsibilities of employees health care when developing and implementing policies and strategies to achieve overall health coverage.

To respond to these political challenges and manage migration, WHO recommends that governments act in three ways ${ }^{20}$ :

- improve the available data on the migration flows of medical workers for more effective monitoring of trends;

- pay closer attention to different options for managing migration processes in order to reduce its negative impact on the provision of health workers;

- in all countries that are faced with this problem - to ensure the effectiveness of personnel policies, planning and practical actions in the health sector, which will allow better assurance of human resources.

In developing national programs, WHO recommends that governments develop strategies that take into account motivation, working conditions, decent wages, educational opportunities, and other factors that will reduce the outflow of medical personnel ${ }^{21}$. In particular, the resolution adopted at the 57th Session of the WHO European Regional Committee in 2004 by the World Health Organization Assembly WHA57.19 «International migration of health personnel: a threat to health systems in developing countries» ${ }^{22}$ emphasized that the policy promotion of retention of health care personnel should include measures to strengthen human resources through a review of wage rates and the implementation of incentive systems. Personnel policy makers are therefore encouraged to enlist the support of international

${ }^{20}$ Kadry zdravoohraneniya 2030. Globalnaya strategiya dlya razvitiya kadrovyh resursov zdravoohraneniya [Health personnel 2030. Global strategy for health workforce development. WHO: website. Retrieved from: https://www.who.int/hrh/resources/russian_global_ strategyHRH.pdf (accessed 12 November 2019).

${ }^{21}$ Politika v otnoshenii trudovyh resursov zdravoohraneniya v Evrope [Health workforce policies in the European Region]. Euro: website. Retrieved from: http://www.euro.who.int/ document/rc57/edoc09.pdf (accessed 11 November 2019).

22 Mezhdunarodnaya migraciya i medicinskij personal: problema dlya sistem zdravoohraneniya $\mathrm{v}$ razvivayushihsya stranah [International migration and health personnel: a challenge for health systems in developing countries]. WHO: website. Retrieved from: http://www.who.int/gb/ebwha/pdf_files/WHA57/A57_R19-en.pdf (accessed 12 November 2019). 
organizations and governments of importing countries, which in turn will help to identify the most effective balance of key interventions (such as recruiting within the country, improving the conditions for retaining professionals and returning to work, non-practitioners). Also, as noted in the program document of the Directorate of Health and Social Affairs of Norway $^{23}$ only when creating effective interagency agreements and achieving cooperation of all departments (finance, legal regulation, foreign aid, health and immigration, etc.) can one act in common a coherent political direction, which will ensure control and management of the input flow of workers in importing countries. At the same time, it is possible to achieve a really positive contribution of the migration of medical workers to the health care system of importing countries by hiring and promoting equal rights and equal opportunities for health professionals from other countries ${ }^{24}$.

Appropriate recruitment policies include «prompt satisfaction» of work permit requests; developing coordinated approaches to recruitment with the involvement of many employers to achieve economies of scale in the hiring process; developing a cross-sectoral approach to coordinate the employment of healthcare professionals in the country of destination; providing observation during the initial period of work or assisting in adaptation, such as language training and cultural orientation, and providing social support, which in turn can help newcomers to assimilate effectively.

In some countries (England, Ireland, Scotland), international medical associations have developed principles and principles to promote equality and equal opportunity for medical professionals who have been sent from other countries or refugees and to maintain a healthy morale in the health sector, hiring protocols ${ }^{25},{ }^{26}$, . The principles of ethical and effective

\footnotetext{
${ }^{23}$ Nabor medicinskih rabotnikov. Na puti k globalnoj solidarnosti [Recruitment of health workers. Towards global solidarity]. Shdir: http://www.shdir.no/vp/multimedia/archive/00018/ IS-1490E_18611a.pdf (accessed 13 November 2019).

${ }^{24}$ Buchan J, Perfilieva P. Migraciya medicinskih rabotnikov v Evropejskom regione: tematicheskie issledovaniya po stranam i politicheskie posledstviya [Health worker migration in the European Region: country case studies and policy implications]. Euro: website. Retrieved from: http://www.euro.who.int/document/e88366.pdf (accessed 13 November 2019).

${ }^{25}$ Zayavlenie s izlozheniem pozicii po eticheskomu podboru medsester [Position statement on ethical nurse recruitment]. Icn: website. Retrieved from: http://www.icn.ch/psrecruit01.htm (accessed 12 November 2019).

${ }^{26}$ Kodeks praktiki mezhdunarodnogo najma medicinskih rabotnikov: Melburnskij manifest. [A Code of Practice for the International Recruitment of Health Professionals: the Melbourne Manifesto]. Ruralhealth: website. Retrieved from: http://nrha.ruralhealth.org.au/cms/uploads/ publications/melbourne_manifesto.pdf (accessed 11 November 2019).

${ }^{27}$ Rukovodstvo EFN po peredovoj praktike najma mezhdunarodnyh medsester [EFN good practice guidance for international nurse recruitment]. Efnweb: website. Retrieved from: http://www.efnweb.org/version1/en/documents/EFNGoodPracticeGuidanceforRecruitment.doc (accessed 11 November 2019).
} 
international recruitment presented in them are based on an appropriate assessment of the competencies of health professionals from other countries in accordance with the regulatory framework of the host country. This will allow for the assessment of patient safety risk factors associated with the use of multinational staff in another mother tongue, other types of education received, and other approaches to assisting with cultural differences.

Subsequently, with a view to reaching a global consensus on the strategy for the international recruitment of health workers, WHO is initiating the adoption of a Community Code on the international recruitment of health workers $^{28}$, which establishes for the Commonwealth of Nations and Pacific Island Governments a number of leading international States medical professionals. In particular, it calls for the purpose of hindering the targeted recruitment of healthcare workers from countries that are themselves in short supply, as well as protecting the rights of hired workers and providing conditions for professional activity in the hiring countries. It is also emphasized that the recruitment of healthcare workers should be transparent and that recruitment agencies and employers should clearly explain the terms and conditions of employment of the employees they hire: ensuring that candidates have a full understanding of the terms of their contracts; providing them with information on regulatory authorities and the necessary requirements for them; propose additional strategies for retaining qualified personnel. At the same time, recruitment agencies should not hire those who have unsettled obligations in their own countries, which will help to achieve mutual benefits for retaining health care workers domestically.

In order to create mechanisms that would mitigate the negative impact of the outflow of health care system personnel as a result of migration, a resolution WHA59.23 «Rapidly increasing the training of health workers» was adopted at the 59th session of the WHO Assembly ${ }^{29}$. Among the key steps in this direction was the promotion of training in accredited institutions by a full list of highly qualified specialists, facilitating the establishment of planning groups in each country to address the shortage of health workers, involving a wider range of participants, including unions, public and private

${ }^{28}$ Kodeks Sodruzhestva po praktike mezhdunarodnogo najma medicinskih rabotnikov [Commonwealth Code of Practice for the International Recruitment of Health Workers]. The common wealth: website. Retrieved from: http://www.thecommonwealth.org/shared_asp_files/ uploadedfiles/\{7BDD970B-53AE-441D-81DB-

1B64C37E992A \}_CommonwealthCodeofPractice.pdf (accessed 14 November 2019).

${ }^{29}$ Bystroe povyshenie urovnya podgotovki medicinskih rabotnikov [Rapidly increasing the training of health worker]. WHO: website. Retrieved from: http://apps.who.int/gb/ebwha/ pdf_files/WHA59-REC1/r/Part2-Res-ru.pdf (accessed 15 November 2019) 
sectors and non-governmental organizations. However, experts stress ${ }^{30}$ that their overarching goal in developing a comprehensive national strategy for healthcare workers has not been achieved.

Given the complexity of developing national programs for the recruitment of health workers at the 124th session of the Executive Committee in January 2009, governments are invited to participate in discussions on retention at national, regional and global levels, which will improve the WHO Code of Practice international recruitment of health personnel $^{31}$.

A further step in overcoming migration problems was the development of a WHO Framework for Financing and Economic Aspects for the Enhancement and Improvement of Health Care Professionals ${ }^{32}$, which invites resource managers to create global partnership networks to promote more balanced distribution, frames within the country. At the same time, such partnerships should be based on the development of adequate policy approaches to migration management.

At the global level, WHO identifies two possible policy options for countries and regions facing the problem of emigration or immigration of healthcare professionals:

- not to make any interventions by the state, allowing the market to determine the direction, level and dynamics of migration of health care workers;

- facilitate the development of policies that facilitate or streamline the migration process so that neither country is at a loss (policy aimed at improving the monitoring of migration of health care workers, facilitating direct migration flows and improving human resource practices, in

${ }^{30}$ Ocenka finansirovaniya, obrazovaniya, upravleniya i politicheskogo konteksta dlya strategicheskogo planirovaniya kadrovyh resursov zdravoohraneniya [Assessment of financing, education, governance and policy context for strategic health workforce planning]. WHO: website. Retrieved from: (http://apps.who.int/gb/ebwha/pdf_files/WHA59-REC1/r/Part2-Resru.pdf) (accessed 14 November 2019).

${ }^{31}$ Kodeks praktiki Vsemirnoj organizacii zdravoohraneniya po mezhdunarodnomu najmu mediko-sanitarnogo personala [World Health Organization Code of Practice on the International Recruitment of Health Personnel]. WHO: website. Retrieved from: http://www.who.int/hrh/migration/ code/code_background_paper_ru.pdf (accessed 14 November 2019).

32 Finansirovanie i ekonomicheskie aspekty uvelicheniya chislennosti i povysheniya kvalifikacii rabotnikov zdravoohraneniya. Ramochnyj document [Financing and economic aspects of health workforce scale-up and improvement: framework paper]. WHO: website. Retrieved from: http://whqlibdoc.who.int/publications/2008/9789241598286_eng.pdf (accessed 11 November 2019). 
particular, an attempt to direct employees from other countries into geographic or specialization areas that are more in need of additional staff) ${ }^{33}$.

\section{WHO Recommendations for the retention of medical personnel}

Based on evidence of relocation of health workers across national borders and focusing on strategies to increase the number of specialists in remote and rural areas by improving hiring conditions, WHO in Geneva in 2010 develops Recommendations for a Global Policy for Enhancing Access to Healthcare Workers health in remote and rural areas ${ }^{34}$.

The recommendations for retaining and recruiting medical staff in this report are grouped into four main sections: education recommendations, regulatory guidance, financial incentive guidance, and personal and professional support recommendations.

So, recommendations on education include:

1. Use of a targeted recruitment policy (enrollment of students in rural areas to increase the likelihood that graduates will make the decision to pursue their profession in rural areas).

2. Placement of medical schools, campuses, and postgraduate programs in family medicine outside metropolitan and other major cities, since graduates of these schools and programs are more likely to work in rural areas.

3. Providing students with incomplete higher education programs, studying various medical disciplines, gaining experience in rural communities and rotating between health care institutions, as this can have a positive impact on the recruitment and recruitment of health care workers in rural areas.

4. Modifying curricula for part-time and full-time higher education programs, including rural health topics, to increase the competence of health professionals working in rural areas and thus their job satisfaction and their content.

\footnotetext{
${ }^{33}$ Buchan J. Kak upravlyat processom migracii rabotnikov zdravoohraneniya, chtoby snizit lyubye otricatelnye vozdejstviya na obespechennost imi? Kratkij analiticheskij obzor [How to manage the migration of health workers in order to reduce any negative impacts on their wellbeing? Brief analytical overview]. Euro: website. Retrieved from: http://www.euro.who.int/ _data/assets/pdf_file/0009/76428/E93414R.pdf (accessed 12 November 2019).

${ }^{34}$ Rasshirenie dostupa $\mathrm{k}$ rabotnikam zdravoohraneniya $\mathrm{v}$ otdalennyh i selskih rajonah. Rekomendacii po globalnoj politike. [Increased access to health workers in remote and rural areas. Global policy recommendations]. WHO: website. Retrieved from: http://www.who.int/ entity/hrh/retention/retention_recommendations_ru.pdf (accessed 11 November 2019).
} 
5. Develop a continuing education and vocational training program that meets the needs of rural health workers and is carried out at the place of residence and work to support their maintenance.

The Regulatory Guidelines (block II) provide for: the establishment and regulation of an expanded field of practice in rural or remote areas in order to enhance potential job satisfaction that will facilitate recruitment and retention; to increase the number of health care practitioners in rural and remote areas, it is necessary to establish different categories of health care workers with appropriate training; with the aim of expanding the recruitment and retention of health workers in these areas, where compulsory work is required in rural and remote areas, to provide workers with appropriate incentives such as scholarships or financial assistance (educational subsidies).

To enhance rural retention, WHO recommends a set of financial incentives (within its fiscal capacities) - Block III, including preferential loans, heavy labor payments, housing subsidies, free transportation, paid holidays, etc.). It will be sufficient to cover the costs of lost opportunities through work in rural areas (as perceived by healthcare professionals).

The recommendations for personal and professional support (block IV) include:

- improving the living conditions of health workers and their families, investing in infrastructure and services (sanitation, electricity, telecommunications, schools, etc.), as these factors have a significant impact on workers' decision to move to and stay in rural areas;

- the creation of good and safe working conditions (including appropriate equipment and supplies, favorable guidance and mentoring) to ensure the professional attractiveness of these posts and thus increase the recruitment and retention of health workers in remote and rural areas;

- development and implementation of appropriate educational measures that will facilitate cooperation between health workers from areas with good and inadequate care, using telemedicine as a supportive tool;

- developing and supporting a program of career growth and the creation of senior-level posts in rural areas so that health care workers can move up the ladder through their own experience, training and training, not necessarily leaving rural areas;

- support for the development of professional networks, rural associations of health professionals, journals in the field of health care in rural areas, etc.to improve the morale and status of rural health care providers and to reduce the sense of professional isolation; 
- Provision of public recognition measures, such as holding rural health days, awarding awards and titles at local, national and international levels, with a view to enhancing the status of work in rural areas, since these activities provide conditions for enhancing internal motivation and thus promoting, the retention of rural health workers.

These evidence-based recommendations relate to displacement health workers within national boundaries and focused solely on strategies to increase the presence of healthcare workers in remote and rural areas through improved attraction, recruitment and maintenance. They apply to all categories of healthcare professionals in the official regulated health sector, including managers health care and support staff, as well as students seeking or completing training and complementing the ongoing work of the WHO Global Code on the practice of international recruitment ${ }^{35}$.

In our opinion, these recommendations can serve as a basis for program development at the regional and national levels, given the possibility of adapting them to specific conditions of application and implementation. After all, all efforts to improve the recruitment and retention of healthcare workers in remote and rural areas are based on a number of interrelated principles. For example, adhering to the principle of fairness in health can facilitate the allocation of available resources and help reduce and eliminate the manifestations of health inequities, and the enshrining in the national health plan of rural retention policies will provide a basis for accountability for all partners to achieve tangible, measurable results.

At the same time, experts say, the choice of measures to retain and motivate health care workers should be made taking into account the deep understanding of the peculiarities of medical personnel. This requires, at a minimum, a comprehensive situational analysis, in particular of the labor market and the analysis of the factors that influence the decisions of health care workers to move to another country because of other areas, to stay there or to leave $\mathrm{e}^{36}$. At the same time, linking practical policy measures and adapting them to the specific circumstances of each country can only ensure that the broader social, economic and political factors at national, regional

${ }^{35}$ Kadry zdravoohraneniya 2030. Globalnaya strategiya dlya razvitiya kadrovyh resursov zdravoohraneniya [Health personnel 2030. Global strategy for health workforce development] WHO: website. Retrieved from: https://www.who.int/hrh/resources/russian_global_strategy HRH.pdf (accessed 14 November 2019).

36 Mobilnost kadrov zdravoohraneniya v usloviyah bystro izmenyayushejsya Evropy. Novaya dinamika, mobilnyj personal i razlichnye otvetnye dejstviya [Health professional mobility in a changing Europe. New dynamics, mobile individuals and diverse responses]. Euro: website. Retrieved from: http://www.euro.who.int/_data/assets/pdf_file /0006/248343/ Health-Professional-Mobility-in-a-Changing-Europe.pdf) (accessed 12 November 2019). 
and social levels that influence staff retention are properly addressed. Also, to assess options and promote interventions to improve the retention of health care workers, particularly in rural areas, knowledge and experience in central and local HR management is required, and those with well-developed management skills are required to implement selected policy interventions and leadership, especially at the institution level ${ }^{37}$.

Also, to assess options and promote interventions to improve the retention of health care workers, particularly in rural areas, knowledge and experience in central and local HR management is required, and those with well-developed management skills are required to implement selected policy interventions and leadership, especially at the institution level. ${ }^{38}$.

Stakeholder engagement is also an important element in the successful implementation of retention policies. In order to secure the long-term support of all parties involved, WHO recommends involving rural communities, professional associations and policy makers in the formulation of personnel policies ${ }^{39}$.

In order to broaden the scope of the recommendations and cover the recruitment and retention strategy in all under-served regions, the WHO Department of Human Resources for Migration and Retention at the WHO Headquarters in Geneva is responsible for initiating review these global recommendations based on new evidence, research and feedback from the countries that use them. The result of this work was a practical document on a set of WHO recommendations ${ }^{40}$, that, in order to improve the quality of care through the availability of the necessary medical staff foresee, first of all, partnerships in any healthcare facility, regardless of ownership.

${ }^{37}$ Mehanizm ocenki stran VOZ na osnove ispolzovaniya dannyh o kadrovyh resursah zdravoohraneniya [WHO country assessment tool on the uses and sources for human resources for health (HRH) data]. WHO: website. Retrieved from: http://www.who.int/entity/hrh/ resources/HRH_data-online_version_survey_use_sources.pdf (accessed 12 November 2019).

${ }^{38}$ Privlechenie i uderzhanie rabotnikov zdravoohraneniya v subregionalnoj seti VostochnoEvropejskih gosudarstv [Attracting and retaining health workers in the Member States of the South-eastern Europe Health Network]/ Euro: website. Retrieved from: http://www.euro.who.int/_data/assets/pdf_file/0013/152203/e95774.pdf (accessed 14 November 2019)

39 Udovletvorenie potrebnostej $\mathrm{v}$ kadrah dlya obshestvennogo zdravoohraneniya [Addressing needs in the public health workforce in Europe]. Euro: website. Retrieved from: http://www.euro.who.int/_data/assets/pdf_file/0003/248304/Addressing-needs-in-the-publichealth-workforce-in-Europe.pdf (accessed 12 November 2019)

${ }^{40}$ Nabor rekomendacij dlya sozdaniya partnerstva. Prakticheskij dokument dlya sozdaniya partnerstva po uluchsheniyu kachestva medicinskih uslug [Partnership preparation package. A practical document to implement twinning partnerships for improvement]. WHO: website. Retrieved from: http://apps.who.int/iris/bitstream/handle/10665/273158/WHO-HISSDS-2018.13-eng.pdf (accessed 14 November 2019). 
Against this background, to better understand how measures work and why they work in some conditions but are ineffective in others, it is necessary to monitor the migration of health care workers at all levels (regional, national and global). In doing so, it is necessary to carry out scientific analytical studies to assess the effectiveness of personnel policy, to review, if necessary, measures to retain and recruit medical personnel after their implementation, in particular at the regional level, to record valuable lessons learned in the historical aspect, which will increase in the future evidence. Evidence and will facilitate the development of practical measures to retain and engage healthcare professionals at all levels in accordance with the requirements of the evidence assessment system for I have GRADE practical recommendations (relevance, acceptability, affordability, efficiency and impact).

Thus, based on the study of international experience in retaining and engaging health care workers, which testifies to different approaches to solving personnel problems in different countries, and taking into account the different influence of socio-economic and other peculiarities of the country on the migration of health workers, that practical recommendations on the recruitment and retention of medical personnel in Ukraine should be recognized as one of the main tasks in the formulation of personnel policy in the field of health care and should be formulated in accordance with a regional needs, taking into account the specific conditions and factors that determine the negative effects of migration of health care workers. At the same time, their formation should be carried out in accordance with the European vector of development of Ukraine.

\section{CONCLUSIONS}

1. An analysis of WHO strategic documents on the retention and involvement of health professionals demonstrates that there is an urgent need to address the challenges posed by the migration of health workers due to the lack of a universal strategy for developing human resources in the vast majority of countries in the world. I, and practical guidance on keeping them and engaging them in specific circumstances.

2. It has been identified that measures to retain and attract health care workers globally are primarily a political issue that must be addressed in three main areas: to better monitor trends - to improve the available data on migration flows of health care workers; in order to reduce the negative impact of migration on health workers' security - developing different options for managing migration processes; In order to better meet the needs 
of the human resources, to ensure the efficiency of personnel policy, planning and practical actions in the health sector.

3. It has been found that practical recommendations for retaining and involving healthcare professionals at the regional level, particularly in rural and remote areas, address the need to develop education, migration regulation, financial incentive and personal guidance and professional support.

4. It is proved that in order to expand the scope of practical recommendations on retention and involvement of medical personnel and coverage of their recruitment and retention strategy in all underserved regions, it is necessary to create evidence-based evidence on the levels and causes of migration of health care workers that meet the requirements of the international evidence assessment system for the GRADE Practice Guidelines.

5. Studying international experience in retaining and engaging healthcare professionals and different approaches to addressing HR issues in different countries gives us reason to argue that practical guidelines for the recruitment and retention of medical personnel in Ukraine should be tailored to regional needs, taking into account the socio-economic and other characteristics of the country, which determine the main problems of migration in personnel policy in the field of health care.

\section{SUMMARY}

The study provides a scientific and theoretical substantiation of the place and role of measures to retain and involve health workers in the personnel policy of the WHO European Region health system. Indeed, the ability of healthcare systems to function effectively and respond appropriately to new challenges is largely dependent on the availability of sufficient health professionals who possess the necessary skills and work where they are needed, in an environment conducive to their motivation and attraction.

A systematic analysis of WHO strategic documents on the retention and involvement of health workers was carried out, which made it possible to identify the main directions of personnel policy for solving the problems of international migration and migration of health workers domestically at the global and regional levels. It has been identified that measures to retain and attract health care workers at the global level are first and foremost a political issue that should be addressed in three main areas: improving the available data on the migration flows of health care workers; developing different options for managing migration processes; ensuring the effectiveness of personnel policy, planning and action in the health sector. 
Recommendations for retaining and engaging health professionals at the regional level, particularly in rural and remote areas, address the need to develop recommendations on education, migration regulation, financial incentives and personal and professional support.

Based on the WHO documents, the necessity and development of practical recommendations for solving human resources problems in the health care of Ukraine, including the problems of migration and their recognition as one of the main tasks in the formulation of personnel policy in the field of health care, are considered and substantiated. Conditions and factors that determine the negative effects of migration of health care workers on the country. At the same time, their formation should be carried out in accordance with the European vector of development of Ukraine.

\section{REFERENCES}

1. Kadrovye resursy zdravoohraneniya [Health workforce] // Euro: website. Retrieved from: http://www.euro.who.int/ru/health-topics/Healthsystems/health-workforce/health-workforce (accessed 15 November 2019).

2. Migraciya rabotnikov zdravoohraneniya [Migration of health workers]. WHO: website. Retrieved from: http://www.who.int/mediacentre/ factsheets/fs301/ru/index.html (accessed 18 November 2019).

3. Findlay A, Lowell L. (2002) Migratsiia vysokokvalifitsirovannykh spetsialistov iz razvivaiushchikhsia stran: vozdeistvie i otvetnye mery na urovne politiki. [Migration of highly skilled persons from developing countries: impact and policy responses]. International Labour Organization, Dokumenty po mezhdunarodnoi migratsii [International Labour Organization, International Migration Papers]. Geneva, no. 43.

4. Vsemirnyj doklad ob ohrane zdorovya 2006 goda - sovmestnaya rabota $\mathrm{v}$ interesah ohrany zdorovya [The world health report 2006 - working together for health. Geneva, World Health Organization]. , WHO: website. Retrieved from: http://www.who.int/whr/2006/en/ (accessed 13 November 2019).

5. Razvitie medicinskih kadrov [Medical personnel development]. WHO: website. Retrieved from: http://whodc.mednet.ru/ru/component/ attachments/download/20.html (accessed 13 November 2019).

6. Kajgoroda T. V. (2019) Kadrovye resursy zdravoohraneniya [Health personnel resources]. Socialnye aspekty zdorovya naseleniya (electronic journal), vol. 3, no 67. Retrieved from: http://vestnik.mednet.ru/content/ view/1081/30/lang,ru_ru.cp1251. (accessed 12 November 2019)

7. Wismar M., Maier C.B., Glinos I.A., Dussault G., Figueras J. (2011) Mobilnost medicinskikh rabotnikov i sistemy zdravookhraneniya. 
Fakticheskie dannye iz 17 stran [Health professional mobility and health systems. Evidence from 17 European countries]. Evropeiskoe regionalnoe biuro VOZ [WHO Regional Office for Europe] . Copenhagen, $597 \mathrm{pp}$.

8. Vseobshaya realnost: bez trudovyh resursov net zdoroCopenhagenvya [A Universal Truth: No health without a workforce]. WHO: website. Retrieved from: http://www.who.int/workforcealliance/ knowledge/resources/hrhreport2013/ en/index.html (accessed 11 November 2019)

9. G. Dussault, J. Buchan, W. Sermeus, Z. Padaiga. Ocenka budushih potrebnostej $\mathrm{v}$ kadrovyh resursah zdravoohraneniya [Assessment of future health workforce needs].Euro: website. Retrieved from: http://www.euro.who.int/_data/assets/pdf_file/0018/133038/e94295R.pdf (accessed 13 November 2019)

10. Rukovodstvo po monitoringu i otsenke kadrovykh resursov zdravookhraneniia (spetsialno dlia stran $\mathrm{s}$ nizkim i srednim urovnem dokhoda) [Guidance on monitoring and evaluation of the health workforce (specifically for low- and middle-income countries)] Evropeiskoe regionalnoe biuro VOZ [WHO Regional Office for Europe] . Copenhagen, $88 \mathrm{pp}$.

11. Dokument A72/24 Semdesiat vtoroi sessii Vsemirnoi assamblei zdravookhraneniia [Document A72/24 Seventy-second World Health Assembly]. Retrieved from: http://apps.who.int/gb/ebwha/pdf_files/ WHA72/A72_24-ru.pdf. (accessed 11 November 2019)

12. Stilwell B et al. (2003) Razrabotka osnovannoi na fakticheskikh dannykh eticheskoi politiki $v$ otnoshenii migratsii meditsinskikh rabotnikov: kontseptualnye i prakticheskie problemy [Developing evidence based ethical policies on the migration of health workers: conceptual and practical challenges]. Liudskie resursy dlia zdravookhraneniia.

13. Dumont J, Zurn P. (2007) Meditsinskie rabotniki-immigranty v stranakh OESR $\mathrm{v}$ bolee shirokom kontekste vysokokvalifitsirovannoi migratsii [Immigrant health workers in OECD countries in the broader context of highly skilled migration]. SOPEMI Ed. Perspektivy mezhdunarodnoi migratsii. Organizatsiia ekonomicheskogo sotrudnichestva i razvitiia. [SOPEMI ed. International migration outlook. Organisation for Economic Co-operation and Development]. Parish.

14. Robinson R. (2007) Zatraty i vygody migracii medicinskih rabotnikov iz Vostochnoj i Yuzhnoj Afriki (VYuA) [The costs and benefits of health worker migration from East and Southern Africa (ESA]). Literature review. Harare, EQUINET, 2007 (EQUINET Discussion Paper 49; 
Retrieved from: http://www.equinetafrica.org/bibl/docs/ DIS49HR. robinson.pdf (accessed 14 November 2019).

15. Bueno de Mesquita J, Gordon M. (2005) Mezhdunarodnaya migraciya medicinskih rabotnikov: analiz soblyudeniya prav cheloveka [The international migration of health workers: a human rights analysis]. Medact, (electronic journal). Retrieved from: http://www.medact.org/content/Skills\% 20drain/ Bueno\%20de\%20Mesquita\%20and\%20Gordon.pdf (accessed 10 November 2019).

16. Buchan J, Perfilieva P. Migraciya medicinskih rabotnikov v Evropejskom regione: tematicheskie issledovaniya po stranam i politicheskie posledstviya. [Health worker migration in the European Region:country case studies and policy implications]. Euro: website. Retrieved from: http://www.euro.who.int/document/e88366.pdf (accessed 10 November 2019).

17. Diallo K. (2004) Dannye o migratsii meditsinskikh rabotnikov: istochniki, vidy ispolzovaniia i problemy [Data on the migration of healthcare workers: sources, uses, and challenges].Bulletin of the World Health Organization, 82:559-636.

18. Auriol L, Sexton J. (2002) Liudskie resursy v oblasti nauki i tekhnologii: voprosy izmereniia i mezhdunarodnaia mobilnost [Human resources in science and technology:measurement issues and international mobility] Organizatsiia ekonomicheskogo sotrudnichestva i razvitiia [Organisation for Economic Co-operation and Development]. Paris: pp. 13-39.

19. Tretii globalnyi forum po kadrovym resursam zdravookhraneniia (2013) Kadrovye resursy zdravookhraneniia: osnova dlia obespecheniia vseobshchego okhvata mediko-sanitarnymi uslugami $i$ povestka dnia $v$ oblasti razvitiia na period posle 2015 goda [Human resources for health: a framework for universal health coverage and the post-2015 development agenda]. Recife, Brazil.

20. Kadry zdravoohraneniya 2030. Globalnaya strategiya dlya razvitiya kadrovyh resursov zdravoohraneniya [Health personnel 2030. Global strategy for health workforce development. WHO: website. Retrieved from: https://www.who.int/hrh/resources/russian_global_strategyHRH.pdf (accessed 12 November 2019).

21. Politika $\mathrm{v}$ otnoshenii trudovyh resursov zdravoohraneniya $\mathrm{v}$ Evrope [Health workforce policies in the European Region]. Euro: website. Retrieved from: http://www.euro.who.int/document/rc57/edoc09.pdf (accessed 11 November 2019).

22. Mezhdunarodnaya migraciya i medicinskij personal: problema dlya sistem zdravoohraneniya $\mathrm{v}$ razvivayushihsya stranah [International 
migration and health personnel: a challenge for health systems in developing countries]. WHO: website. Retrieved from: http://www.who.int/gb/ebwha/ pdf_files/WHA57/A57_R19-en.pdf (accessed 12 November 2019).

23. Nabor medicinskih rabotnikov. Na puti k globalnoj solidarnosti [Recruitment of health workers. Towards global solidarity]. Shdir: http://www.shdir.no/vp/multimedia/archive/00018/IS-1490E_18611a.pdf (accessed 13 November 2019).

24. Buchan J, Perfilieva P. Migraciya medicinskih rabotnikov $\mathrm{v}$ Evropejskom regione: tematicheskie issledovaniya po stranam i politicheskie posledstviya [Health worker migration in the European Region: country case studies and policy implications]. Euro: website. Retrieved from: http://www.euro.who.int/document/e88366.pdf (accessed 13 November 2019).

25. Zayavlenie s izlozheniem pozicii po eticheskomu podboru medsester [Position statement on ethical nurse recruitment]. Icn: website. Retrieved from: http://www.icn.ch/psrecruit01.htm (accessed 12 November 2019).

26. Kodeks praktiki mezhdunarodnogo najma medicinskih rabotnikov: Melburnskij manifest. [A Code of Practice for the International Recruitment of Health Professionals: the Melbourne Manifesto]. Ruralhealth: website. Retrieved from: http://nrha.ruralhealth.org.au/cms/ uploads/publications/ melbourne_manifesto.pdf (accessed 11 November 2019).

27. Rukovodstvo EFN po peredovoj praktike najma mezhdunarodnyh medsester [EFN good practice guidance for international nurse recruitment]. Efnweb: website. Retrieved from: http://www.efnweb.org/version1/ en/documents/EFNGoodPracticeGuidanceforRecruitment.doc (accessed 11 November 2019).

28. Kodeks Sodruzhestva po praktike mezhdunarodnogo najma medicinskih rabotnikov [Commonwealth Code of Practice for the International Recruitment of Health Workers]. The common wealth: website. Retrieved from: http://www.thecommonwealth.org/shared_asp_files/ uploadedfiles/\{7BDD970B-53AE-441D-81DB-1B64C37E992A _ CommonwealthCodeofPractice.pdf (accessed 14 November 2019).

29. Bystroe povyshenie urovnya podgotovki medicinskih rabotnikov [Rapidly increasing the training of health worker]. WHO: website. Retrieved from: http://apps.who.int/gb/ebwha/pdf_files/WHA59-REC1/r/Part2-Resru.pdf (accessed 15 November 2019).

30. Ocenka finansirovaniya, obrazovaniya, upravleniya i politicheskogo konteksta dlya strategicheskogo planirovaniya kadrovyh resursov zdravoohraneniya [Assessment of financing, education, governance and policy context for strategic health workforce planning]. WHO: website. 
Retrieved from: (http://apps.who.int/gb/ebwha/pdf_files/WHA59-REC1/r/ Part2-Res-ru.pdf) (accessed 14 November 2019).

31. Kodeks praktiki Vsemirnoj organizacii zdravoohraneniya po mezhdunarodnomu najmu mediko-sanitarnogo personala [World Health Organization Code of Practice on the International Recruitment of Health Personnel]. WHO: website. Retrieved from: http://www.who.int/hrh/ migration/code/code_background_paper_ru.pdf (accessed 14 November 2019).

32. Finansirovanie i ekonomicheskie aspekty uvelicheniya chislennosti i povysheniya kvalifikacii rabotnikov zdravoohraneniya. Ramochnyj document [Financing and economic aspects of health workforce scale-up and improvement: framework paper]. WHO: website. Retrieved from: http://whqlibdoc.who.int/publications/2008/9789241598286_eng.pdf (accessed 11 November 2019).

33. Buchan J. Kak upravlyat processom migracii rabotnikov zdravoohraneniya, chtoby snizit lyubye otricatelnye vozdejstviya na obespechennost imi? Kratkij analiticheskij obzor [How to manage the migration of health workers in order to reduce any negative impacts on their well-being? Brief analytical overview]. Euro: website. Retrieved from: http://www.euro.who.int/_data/assets/pdf_file/0009/76428/E93414R.pdf (accessed 12 November 2019).

34. Rasshirenie dostupa k rabotnikam zdravoohraneniya $\mathrm{v}$ otdalennyh i selskih rajonah. Rekomendacii po globalnoj politike. [Increased access to health workers in remote and rural areas. Global policy recommendations]. WHO: website. Retrieved from: http://www.who.int/entity/hrh/retention/ retention_recommendations_ru.pdf (accessed 11 November 2019).

35. Kadry zdravoohraneniya 2030. Globalnaya strategiya dlya razvitiya kadrovyh resursov zdravoohraneniya [Health personnel 2030. Global strategy for health workforce development] WHO: website. Retrieved from: https://www.who.int/hrh/resources/russian_global_strategyHRH.pdf (accessed 14 November 2019).

36. Mobilnost kadrov zdravoohraneniya $\mathrm{v}$ usloviyah bystro izmenyayushejsya Evropy. Novaya dinamika, mobilnyj personal i razlichnye otvetnye dejstviya [Health professional mobility in a changing Europe. New dynamics, mobile individuals and diverse responses]. Euro: website. Retrieved from: http://www.euro.who.int/_data/assets/pdf_file/ 0006/248343/Health-Professional-Mobility-in-a-Changing-Europe.pdf) (accessed 12 November 2019).

37. Mehanizm ocenki stran VOZ na osnove ispolzovaniya dannyh o kadrovyh resursah zdravoohraneniya [WHO country assessment tool on the 
uses and sources for human resources for health (HRH) data]. WHO: website. Retrieved from: http://www.who.int/entity/hrh/resources/ HRH_data-online_version_survey_use_sources.pdf (accessed 12 November 2019).

38. Privlechenie i uderzhanie rabotnikov zdravoohraneniya $\mathrm{v}$ subregionalnoj seti Vostochno-Evropejskih gosudarstv [Attracting and retaining health workers in the Member States of the South-eastern Europe Health Network]/ Euro: website. Retrieved from: http://www.euro.who.int/_data/assets/pdf_file/0013/152203/e95774.pdf (accessed 14 November 2019)

39. Udovletvorenie potrebnostej $\mathrm{v}$ kadrah dlya obshestvennogo zdravoohraneniya [Addressing needs in the public health workforce in Europe]. Euro: website. Retrieved from: http://www.euro.who.int/_ data/assets/pdf_file/0003/248304/Addressing-needs-in-the-public-healthworkforce-in-Europe.pdf (accessed 12 November 2019)

40. Nabor rekomendacij dlya sozdaniya partnerstva. Prakticheskij dokument dlya sozdaniya partnerstva po uluchsheniyu kachestva medicinskih uslug [Partnership preparation package. A practical document to implement twinning partnerships for improvement]. WHO: website. Retrieved from: http://apps.who.int/iris/bitstream/handle/10665/273158/ WHO-HIS-SDS-2018.13-eng.pdf (accessed 14 November 2019).

Information about the author: Keretsman A. O. orcid.org/0000-0002-8902-2227 Associate Professor of the Department of Social Medicine and Hygiene Uzhgorod National University 1, Narodna Sq., 88000, Uzhhorod, Ukraine 


\section{DESCRIPTION OF UKRAINIAN STUDENTS' AWARENESS OF PERSONAL HEALTH PROTECTION AND THEIR LIFESTYLE STUDY RESULTS}

\section{Zhdanova O. V.}

\section{INTRODUCTION}

Health of students as the nation's intellectual and labor potential is an important challenge for any country ${ }^{1}$. Scientists around the world study this issue. $^{2}$ The increasingly stringent requirements for specialist training and qualification level in higher educational institutions result in excessive strain for students and deterioration of their health. For instance, physical and psychological/emotional strain results in exhaustion of adaptation reserves of the nervous, endocrine and immune systems, thus increasing the risk of diseases ${ }^{3},{ }^{4}$. Researchers state that students' health deteriorates significantly over the time of their university studies and that by graduation time only $20 \%$ of the graduates may be considered to be apparently healthy people ${ }^{5}$.

At the same time, lifestyle factors also impact the health of population including students. Pursuant to $\mathrm{WHO}^{67}$, this factor contributes to $50-55 \%$ of human health factors. In particular, the affecting factors include unhealthy nutrition, recurrent stress, labor, substandard domestic and economic

1 Hrebnyak N.P. Students' Health and Lifestyles / N.P. Hrebnyak, V.P. Hrebnyak, V.V. Mashinistov // Issues of Social Hygiene, Health Care and Medical Sphere History. - 2007. № 4. - P. 33-37.

${ }^{2}$ Hooper L., Abdelhamid A., Moore H.J., Douthwaite W., Skeaff C.M., Summerbell C.D. Effect of reducing total fat intake on body weight: systematic review and meta-analysis of randomised controlled trials and cohort studies. British Medical Journal, 2012. no. 12. P. 12-15.

${ }^{3}$ Baklykova A.V. Health and Lifestyles of Medical Students // Molodoy Ucheniy - 2010. № 5. V. 2. - P. 205-207.

4 Sadvakasov T.M. Comparative Characteristic of Young Persons' Lifestyles // T.M. Sadvakasov, Sh.D. Dzhaketayeva, G.A. Zhanalina, Z.A. Aldanova, K.T. Abdrakhmanov, T.S. Sergaliyev, D.B. Kulov // Medical Science and Ecology. - 2015. - № 1(74). - P. 46-47.

5 Shagina I.R. Impact of Studies on Students' Health // Astrakhan Medical Journal. 2010. - № 2. - P. 26-29.

${ }^{6}$ Fats and fatty acids in human nutrition: report of an expert consultation. Food and Agricultural Organization of the United Nations / FAO Food and Nutrition. - Rome, Italy. 2010. - P. 91.

${ }^{7}$ Diet, nutrition and the prevention of chronic diseases: report of a Joint WHO/FAO Expert Consultation. World Health Organization - WHO Technical Report Series, No. 916. - Geneva, Switzerland, -2003. 
conditions, physical inactivity, tobacco, alcohol and drug abuse, uncontrolled use of medications and low cultural level.

The research of students' health displayed that health deterioration directly depends on their lifestyles ${ }^{8,9}$.

According to O.S. Popkova ${ }^{10}$, popular students' unhealthy habits especially alert the researchers with regard to alcohol use, which is attributed to young females $(73 \%)$ even more often than to young males $(66 \%)$. Typically, though, young females use low-alcohol beverages periodically, while young males use stronger drinks and do it significantly more often. Smoking habit is an equally hazardous phenomenon in this environment (77\% of young females and $85 \%$ of young males, with $50 \%$ of regular female smokers and $76 \%$ of male smokers). Based on the poll, more than $38 \%$ of young males and $26 \%$ of young females experimented with narcotic substances, and $11 \%$ of young males and $2 \%$ of young do it on a regular basis. None of the subjects admitted parenteral use of narcotic substances. Also, a high level of gastrointestinal tract diseases (41\%) was detected in student community due to substantial malnutrition. Students are far from leading healthy lives. This is confirmed by statistics stating that students dedicate their leisure time either to friends or to personal computers ${ }^{11}$. At the same time, the students are informed wrongly about sexual intercourse and contraception methods. This increases risks of unawareness and lack of knowledge about medical consequences of abortions ${ }^{12}$.

Physical training and sports represent the main elements of healthy lifestyle. The research results demonstrate ${ }^{13}$ that $49 \%$ of young males and $64 \%$ of young females exercise once or twice a week and $29 \%$ and $19 \%$, correspondingly, three or four times a week. The main motivations stated by the students as reasons behind their sports exercise include the motivation to improve own health $(57 \%)$, to gain healthy looks $(51 \%)$, to be more fit

\footnotetext{
${ }^{8}$ Harkusha S.V. Description of Contemporary Youths Health State in Ukraine. Chernihiv Shevchenko National Pedagogical University's Journal. Series on pedagogical science and physical culture2013;1(107):92-5.

${ }^{9}$ Ponomaryova L.A. Analysis of Medical Students Health Level / L.A. Ponomaryova, S.I. Dvoynikov // Family Health, XXI Century: materials of the VI th scientific international conference - Perm', 2002. - p. 111-112.

${ }_{10}$ Popkova O.S. Social and Hygienic Features in Health Maintaining Behavior of Studentds // Molodoy Ucheniy. - 2015. - № 6.4 - p. 44-46. - URL https://moluch.ru/archive/ 86/16378/ (application date: 09.11.2019).

${ }^{11}$ Zhdanova O.V. Level of Internet Dependence of Student Use (based on sociological study) / O.V. Zhdanova, G.O. Slabkiy // Ukraine. Zdorovya Natsiyi. 2019. - № 2 - - P. 55-58

12 Baklykova A.V. Health and Lifestyle of Medical Students. Molodoy Ucheniy. 2010;5:205-7.

${ }^{13}$ Ushakova Ya.V. Health of Students and Factors of it Formastion /Ya.V. Ushakova // Nizhegorodskiy Lobachevskiy University Journal 2017. - №4 - p.197-202
} 
(47\%), to be in better shape (49\%), to get rid of fatigue and increase work performance (26\%). However, only 39\% perceive physical exercise and sports as elements of healthy way of life.

The issue of maintaining and strengthening student youths' health is a complex and multilayered issue. Due to the changes in today's economic realities, this problem calls for a new approach to attack it. Health sector has to find new forms of medical assistance provision including the design of efficient methods of mass preventive examinations and development of healthy culture in students stimulating them to treat their health as their valuable asset ${ }^{14}$.

Human psychology is built in such a way that while they are young and healthy they hardly care about their health. This approach continues until they feel specific symptoms of health problems. The setup of health care for students shall take into account that students are increased risk social group related to age-related issues, adaptation to physiological and anatomical changes, high psycho-emotional and intellectual stress, adaptation to new living conditions and educational environment and shaping of interpersonal relationships.

The analysis of published research data related to students' attitude towards their health witnesses certain problems in this area. The key issues are: unhealthy habits (alcohol, drugs and tobacco abuse), untimely meals, lack of sleep, insufficient physical activity, etc. However, when assessing their health, most students state they have good health and almost a quarter of respondents state they have average health.

At the same time, it is important to observe a number of healthy life conditions to maintain and strengthen the students' health. One of the mandatory requirements for healthy life is active lifestyle and systematic physical exercise corresponding to gender, age and health condition, as well as healthy nutrition and refusal from unhealthy habits.

\section{Description of student youths' knowledge of healthy lifestyle and safe behavior}

The research was based on sociological study of 446 students from different departments and of different years if Uzhhorod National University and Ukrainian Dental Academy. The poll covered 217 medical department students (102 young males and 115 young females), 105 dental department students (44 young males and 61 young females) and 124 students of non-

${ }^{14}$ Zhuravlyova I.V., editor. Health of Students: Sociological Analysis. RAS Institute of Sociology. Moscow; 2012. P. 252. 
medical departments (67 young males and 57 young females). The research used both the sociological and statistics research methods.

A special questionnaire was prepared for the sociological research. The questionnaire was reviewed and approved by the resolution of biotic commission of Uzhhorod National University on May 14. 2019, minutes № 2. The questionnaire included an introduction part with questions about the department and academic curriculum, a set of questions for students' self-assessment of their health and a set of questions to assess their actual way of life including nutrition, sleep, physical activity, alcohol use and safe sexual behavior. The students filled out the questionnaires in their classes after the end of lectures. The goal of research was explained to the respondents. The time of questionnaires filling was up to 20 minutes. The questionnaires were handed to the researcher.

The research results were entered into consolidated tables and relative percentage results were calculated.

During the sociological study, the following principles were observed: Helsinki Declaration adopted by the General Assembly of the World Health Organization (1964-2000), Convention of EC on Human Rights and Biomedicine (1997) of the European Convention on Vertebrate Animals Use for Experiments (1986), associated provisions of WHO, International Council of Medical Scientific Societies, International Medical Ethics Code (1983) and the legislation of Ukraine. No students under 18 were invited to take part in the research.

At the first stage of the research, the student youths' awareness of healthy life, safe behavior and prevention of non-communicable and communicable diseases including HIV were studied. The results of polling are shown in table 1

The analysis of data from table 1 indicates that the polled students of all departments marked personal awareness of healthy life knowledge as sufficiently high and the same attributes to personal health maintenance and protection. Out of all questions asked to the students they marked their knowledge as sufficient and satisfactory at least at $70 \%$ level.

The next step of the research was aimed at the study of actual level of students' knowledge of healthy lifestyle, safe behavior and health maintaining techniques. The research used a specialized questionnaire. The collected research results are stated in table 2 . 
Table 1

\section{Level of students' self-assessment of their knowledge of maintaining and improving personal health}

\begin{tabular}{|c|c|c|c|c|c|c|c|}
\hline \multicolumn{2}{|l|}{ Question } & \multicolumn{2}{|c|}{$\begin{array}{c}\text { Medical } \\
\text { Department, p-217 }\end{array}$} & \multicolumn{2}{|c|}{$\begin{array}{c}\text { Dental } \\
\text { Department } \\
\text { p-105 }\end{array}$} & \multicolumn{2}{|c|}{$\begin{array}{c}\text { Other } \\
\text { Departments } \\
\text { p-124 }\end{array}$} \\
\hline & & abs & $\%$ & abs & $\%$ & abs & $\%$ \\
\hline \multirow{3}{*}{$\begin{array}{l}\text { Components of } \\
\text { healthy life }\end{array}$} & 1 & 94 & 43.32 & 31 & 25.00 & 17 & 16.19 \\
\hline & 2 & 93 & 42.86 & 86 & 69.35 & 69 & 65.71 \\
\hline & 3 & 30 & 13.82 & 7 & 5.65 & 19 & 18.09 \\
\hline \multirow{3}{*}{$\begin{array}{l}\text { Rational nutrition } \\
\text { principles }\end{array}$} & 1 & 32 & 14.75 & 29 & 23.39 & 15 & 14.29 \\
\hline & 2 & 144 & 66.36 & 90 & 72.58 & 73 & 69.52 \\
\hline & 3 & 41 & 18.89 & 5 & 4.05 & 17 & 16.19 \\
\hline \multirow{3}{*}{$\begin{array}{l}\text { Physical exercise } \\
\text { standards }\end{array}$} & 1 & 35 & 16.13 & 21 & 16.94 & 15 & 14.29 \\
\hline & 2 & 145 & 66.82 & 96 & 77.42 & 45 & 42.86 \\
\hline & 3 & 37 & 17.05 & 7 & 5.65 & 45 & 42.86 \\
\hline \multirow{3}{*}{$\begin{array}{l}\text { Stress prevention } \\
\text { principles }\end{array}$} & 1 & 24 & 11.06 & 12 & 9.68 & 11 & 10.48 \\
\hline & 2 & 144 & 66.36 & 95 & 76.61 & 77 & 73.33 \\
\hline & 3 & 49 & 22.58 & 17 & 13.71 & 17 & 16.19 \\
\hline \multirow{3}{*}{$\begin{array}{l}\text { HIV infection } \\
\text { prevention }\end{array}$} & 1 & 52 & 23.96 & 42 & 33.87 & 27 & 25.71 \\
\hline & 2 & 135 & 62.21 & 67 & 54.03 & 69 & 65.71 \\
\hline & 3 & 29 & 13.36 & 15 & 12.09 & 9 & 8.57 \\
\hline \multirow{3}{*}{$\begin{array}{c}\text { Sexually } \\
\text { transmitted } \\
\text { diseases } \\
\text { prevention }\end{array}$} & 1 & 84 & 38.71 & 31 & 25.00 & 30 & 28.57 \\
\hline & 2 & 121 & 55.76 & 84 & 67.74 & 64 & 60.95 \\
\hline & 3 & 12 & 5.53 & 9 & 7.26 & 11 & 10.48 \\
\hline \multirow{3}{*}{$\begin{array}{l}\text { Health damage } \\
\text { due to tobacco use }\end{array}$} & 1 & 34 & 15.67 & 29 & 23.39 & 17 & 16.19 \\
\hline & 2 & 154 & 70.97 & 90 & 72.58 & 73 & 69.52 \\
\hline & 3 & 29 & 13.36 & 5 & 66.36 & 15 & 14.29 \\
\hline \multirow{3}{*}{$\begin{array}{l}\text { Health damage } \\
\text { due to alcohol use }\end{array}$} & 1 & 45 & 20.74 & 31 & 25.00 & 21 & 20.00 \\
\hline & 2 & 141 & 64.98 & 86 & 69.35 & 73 & 69.52 \\
\hline & 3 & 31 & 14.29 & 7 & 5.65 & 11 & 10.48 \\
\hline \multirow{3}{*}{$\begin{array}{c}\text { Health damage } \\
\text { due to narcotics } \\
\text { use }\end{array}$} & 1 & 44 & 20.28 & 32 & 25.81 & 19 & 18.09 \\
\hline & 2 & 116 & 53.46 & 91 & 73.39 & 66 & 62.86 \\
\hline & 3 & 57 & 26.27 & 11 & 8.87 & 20 & 19.05 \\
\hline \multirow{3}{*}{$\begin{array}{l}\text { Unwanted } \\
\text { pregnancy } \\
\text { prevention }\end{array}$} & 1 & 94 & 43.32 & 51 & 41.13 & 24 & 19.35 \\
\hline & 2 & 110 & 50.69 & 62 & 50.00 & 72 & 58.06 \\
\hline & 3 & 13 & 5.99 & 11 & 8.87 & 9 & 7.26 \\
\hline
\end{tabular}

Note: 1-sufficient, 2 - satisfactory, 3 - uninformed. 
Table 2

Students' awareness of healthy lifestyle and safe behavior

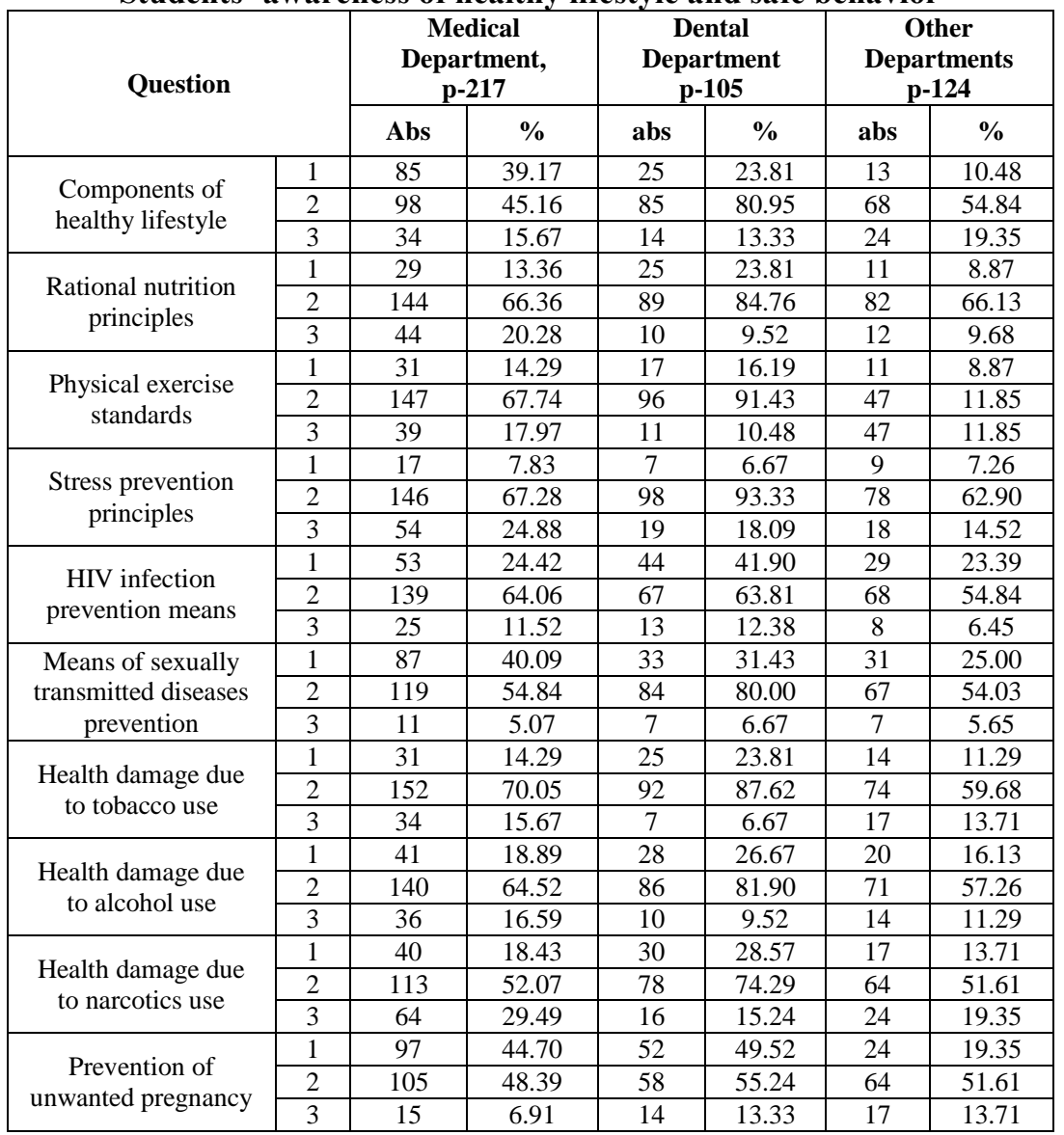

Note: 1-sufficient, 2 - satisfactory, 3 - wrong answer.

The results of the research aimed at the study of actual students' knowledge of healthy lifestyle, safe behavior and health maintaining technologies stated in table 2 indicated a rather high level of students' awareness of the said issues. The actual awareness level is lower by a statistically negligible value as compared to their self-assessment. The awareness level of medical and dental department students is higher that non-medical department students. 
In general, the research results indicate a rather high level of student knowledge of issues related to healthy lifestyle, safe behavior and health maintaining technologies.

\section{Description of lifestyle and behavior aimed at maintaining and improving personal health}

Thereafter, certain components of the polled students' lifestyle were studied. These related to the nutrition of the students, their physical exercise level and sleep duration. The results are stated in table 3.

The results witness the fact that a significant number of students lead lives, which don't help neither maintain nor improve personal health. For instance, $52.27 \%$ of young males of the dental department, $42.11 \%$ of young female students and $40.29 \%$ of young male students of non-medical departments sleep less than 4 hours a day. Malnutrition with regard to the meals timing, as well as to foods range and quality of food products applies to more than $70 \%$ of students of all departments regardless of gender with the exception of young female students of the medical department who violate the nutrition rules in $49.56 \%$ of instances. At the same time, more than $60 \%$ of the polled students drink sugar-containing carbonated beverages on a daily basis.

All the polled students have insufficient physical exercise. Less than 25\% of the polled students exercise daily, except of young males from the dental department, where $27.27 \%$ of the polled students do physical exercise daily. Less than $30 \%$ of all polled students regardless of gender or faculty go to the gym or swimming pool. At the same time, more than $75 \%$ of the polled students walk less than 5000 steps daily. The least number of steps is covered by young females from the dental department. This group's percentage covering more than 5000 steps daily equals $11.48 \%$. At the same time, the people spending more than 2 hours using their computers daily amount to more than $40 \%$.

The next step of the study was the sexual behavior research and condom use as HIV and STD infections prevention as well as unwanted pregnancy avoidance. The results are shown in table 4 .

The analysys of data from table 4 indicates that more than $70 \%$ of the polled students over the 12 months prior to the poll had sexual intercourse. The overwhelming majority of the polled students have one intercourse partner. Dental department students (34.38\% of young males) have at least three intercourse partners and the same result was claimed by $15.79 \%$ of young males from non-medical departments. 
Table 3

Selected data on the polled students' lifestyles

\begin{tabular}{|c|c|c|c|c|c|c|c|}
\hline \multicolumn{2}{|l|}{ Description } & \multicolumn{2}{|c|}{$\begin{array}{c}\text { Medical } \\
\text { Department }\end{array}$} & \multicolumn{2}{|c|}{$\begin{array}{c}\text { Dental } \\
\text { Department }\end{array}$} & \multicolumn{2}{|c|}{$\begin{array}{c}\text { Other } \\
\text { Departments }\end{array}$} \\
\hline & & abs & $\%$ & abs & $\%$ & abs & $\%$ \\
\hline \multirow{2}{*}{$\begin{array}{c}\text { At least } 7 \text { hours of } \\
\text { sleep, daily }\end{array}$} & 1 & 27 & 26.47 & 11 & 25.00 & 24 & 35.82 \\
\hline & 2 & 31 & 26.96 & 14 & 22.95 & 21 & 36.84 \\
\hline \multirow{2}{*}{$\begin{array}{l}\text { Less than } 4 \text { hours of } \\
\text { sleep, daily }\end{array}$} & 1 & 39 & 38.24 & 23 & 52.27 & 27 & 40.29 \\
\hline & 2 & 27 & 23.48 & 21 & 34.43 & 24 & 42.11 \\
\hline \multirow{2}{*}{ Regular meals } & 1 & 15 & 14.71 & 7 & 15.91 & 14 & 20.89 \\
\hline & 2 & 31 & 26.96 & 12 & 19.67 & 16 & 28.07 \\
\hline \multirow{2}{*}{$\begin{array}{l}\text { Foods range and } \\
\text { quality tracking }\end{array}$} & 1 & 11 & 10.78 & 7 & 15.91 & 14 & 20.89 \\
\hline & 2 & 19 & 16.52 & 12 & 19.67 & 16 & 28.07 \\
\hline \multirow{2}{*}{$\begin{array}{c}\text { Haphazard foods } \\
\text { selection }\end{array}$} & 1 & 87 & 85.29 & 37 & 84.09 & 53 & 79.10 \\
\hline & 2 & 57 & 49.56 & 49 & 80.33 & 41 & 71.93 \\
\hline \multirow{2}{*}{$\begin{array}{c}\text { Daily use of sweet } \\
\text { carbonated } \\
\text { beverages }\end{array}$} & 1 & 69 & 67.65 & 32 & 72.73 & 42 & 62.69 \\
\hline & 2 & 71 & 61.74 & 47 & 77.05 & 44 & 77.19 \\
\hline \multirow{2}{*}{$\begin{array}{l}\text { Daily physical } \\
\text { exercise }\end{array}$} & 1 & 19 & 18.63 & 12 & 27.27 & 13 & 19.40 \\
\hline & 2 & 25 & 21.74 & 10 & 16.39 & 9 & 15.79 \\
\hline \multirow{2}{*}{$\begin{array}{l}\text { At least a weekly } \\
\text { visit to the gym }\end{array}$} & 1 & 21 & 20.59 & 11 & 25.00 & 11 & 16.42 \\
\hline & 2 & 32 & 27.83 & 12 & 19.67 & 10 & 17.54 \\
\hline \multirow{2}{*}{$\begin{array}{l}\text { At least a weekly } \\
\text { visit to the } \\
\text { swimming pool }\end{array}$} & 1 & 17 & 16.67 & 12 & 27.27 & 7 & 10.45 \\
\hline & 2 & 21 & 18.26 & 7 & 11.48 & 11 & 19.29 \\
\hline \multirow{2}{*}{$\begin{array}{l}\text { More than } 2 \text { hours } \\
\text { spent daily with PC }\end{array}$} & 1 & 46 & 45.09 & 21 & 47.73 & 24 & 35.82 \\
\hline & 2 & 51 & 44.35 & 27 & 44.26 & 27 & 47.37 \\
\hline \multirow{2}{*}{$\begin{array}{l}\text { At least one monthly } \\
\text { visit to a drama } \\
\text { theater }\end{array}$} & 1 & 4 & 3.92 & 2 & 4.55 & 2 & 2.99 \\
\hline & 2 & 3 & 2.61 & 3 & 4.92 & 7 & 12.28 \\
\hline \multirow{2}{*}{$\begin{array}{l}\text { Covers no less than } \\
5000 \text { steps daily }\end{array}$} & 1 & 23 & 22.55 & 9 & 20.45 & 12 & 17.91 \\
\hline & 2 & 20 & 17.39 & 7 & 11.48 & 14 & 24.56 \\
\hline
\end{tabular}

More than $70 \%$ of all polled students use condoms at all times except for young female students of dental department, where $63.26 \%$ use condoms all the time. During the latest intercourse the students who failed to use condoms most frequently belonged to the medical department $(23.26 \%$, young males) and to non-medical departments (21.88\% young males and 18.37 young females). The said statistics of condom use witness the fact that a significant part of students fails to follow safe sex practices and therefore they are not protected from HIV, STD or unwanted pregnancy. Taking into account the unsafe sexual behavior, depending on the department and gender, from 8.25 to 25.00 percent of the polled students passed HIV tests. 
Taking into account the negative impact of alcohol abuse and other researchers' data on high alcohol use level we had to study the information on students' alcohol intake at this stage of the country's social an economical development and higher education system development in the country. We covered the issues of determining the students' percentage who used alcohol, including the alcohol use over the 30 days preceding this poll, we asked what alcohol beverages the students prefer, enquired about the frequency of alcohol intake and studied the negative impacts of the alcohol use. The research results are quoted in table 5 .

Table 4

Sex-related behavior and condom use practice

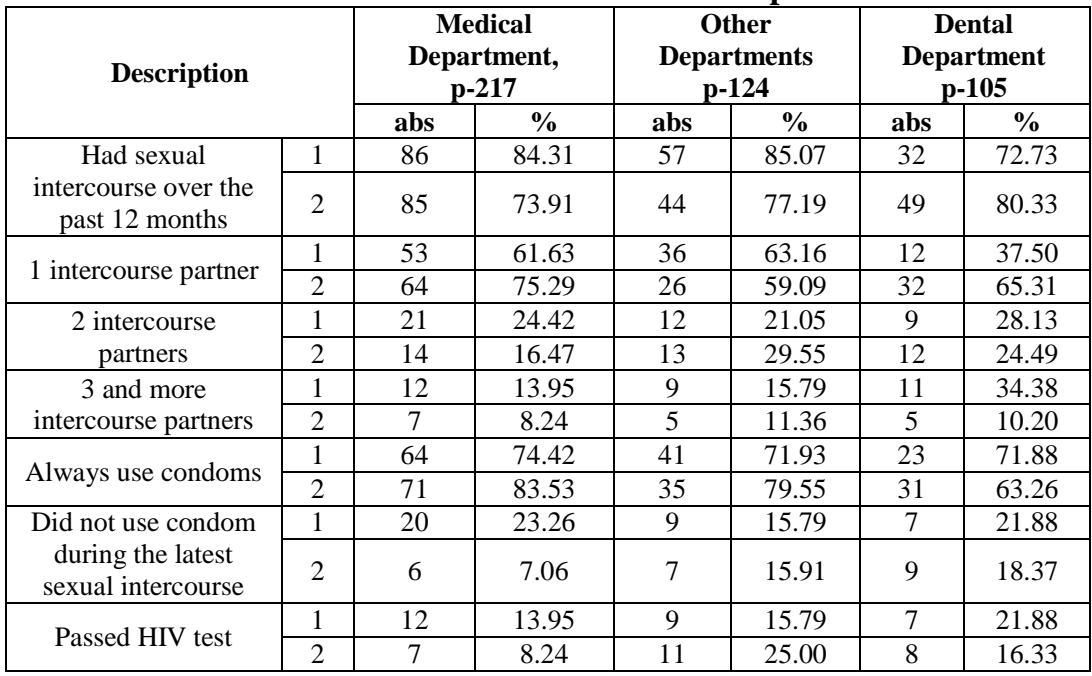

Note: 1-young males, 2 - young females.

The analysis of data from table 5 shows that all of the polled students have alcohol use experience. More than $90 \%$ of the polled students of the medical department and young males from non-medical departments drank alcohol over the past 30 days. The lowest percentage of alcohol users over the past 30 days belonged to the dental department: $68.18 \%$ of young males and $60.66 \%$ of young females. 
Table 5

The history of alcohol beverages intake

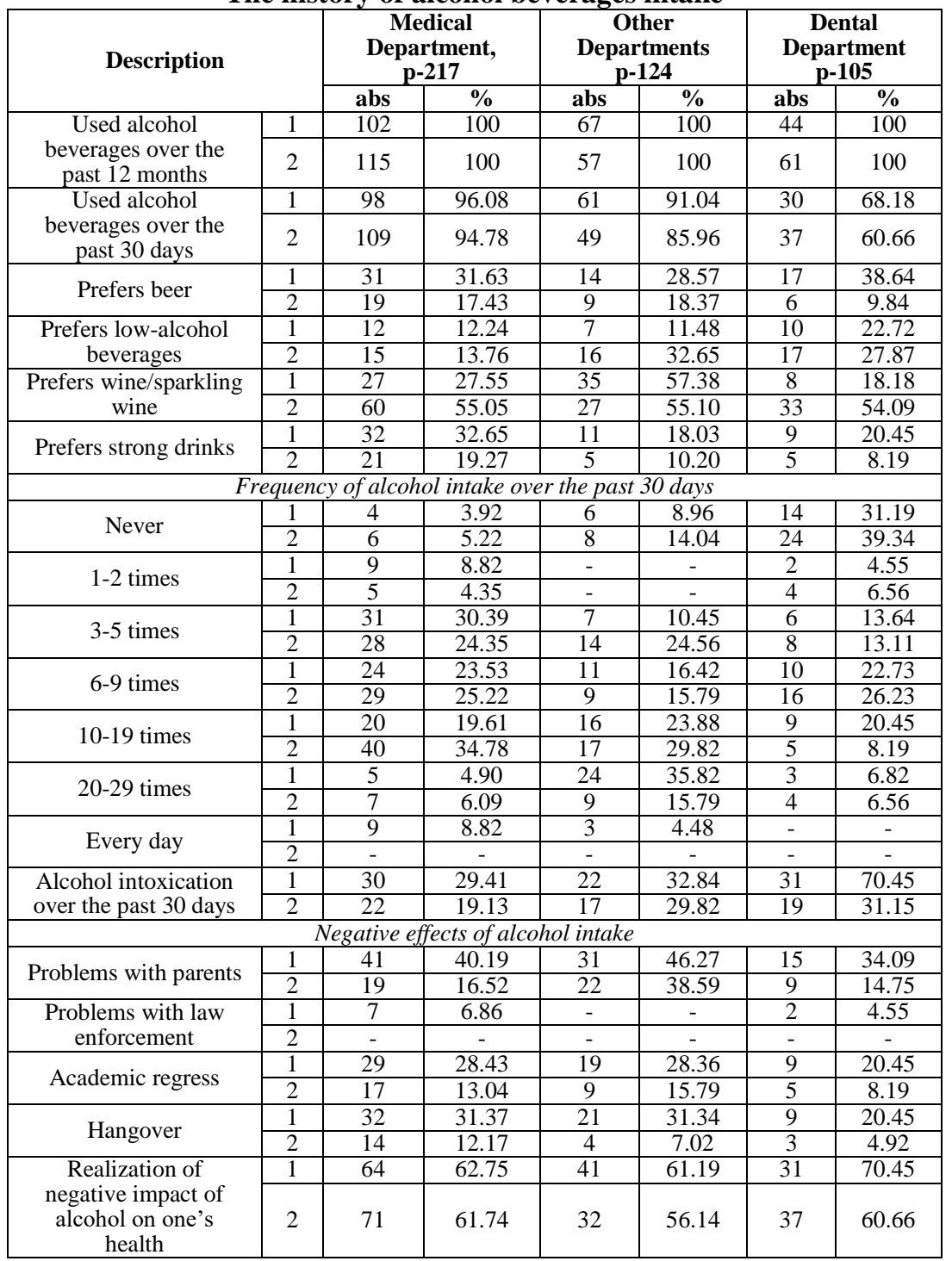

Note: 1-young males, 2 - young females. 
The following alcohol type preferences were discovered by gender and department. Young males from the medical department prefer beer (31.63\%) and strong drinks $(32.65 \%)$, while young females prefer wine/sparkling wine $(55.05 \%)$ and strong drinks (19.27\%). Young male students of dental department prefer beer (38.64\%) and low-alcohol beverages $(22.72 \%)$, and young females - wine/sparkling wine $(54.09 \%)$ and low-alcohol beverages $(27.87 \%)$. Young male students of non-medical departments prefer wine/sparkling wine $(57.38 \%)$ and beer $(28.57 \%)$, and young females wine/sparkling wine $(55.10 \%)$ and low-alcohol beverages $(32.65 \%)$.

As for the frequency of alcohol intake, the data indicate that the most frequent alcohol users (young males) study at the medical department 3-5 times a month (30.39\%), and young females - 10-19 times (34.78\%). Both, young males and young females from the dental department use alcohol most frequently - 6-9 times a month: $22.73 \%$ and $26.23 \%$, correspondingly. Young male students of non-medical departments use alcohol most frequently: 20-29 times a month (35.82\%), and young females: 10-19 times (29.82\%). At the same time, $8.82 \%$ of young males from the medical department and $4.48 \%$ from non-medical departments use alcohol on a daily basis.

Out of those who used alcohol over the past 30 days, the most frequently intoxicated ones were young male students $(70.45 \%)$ and young females $(31.15 \%)$ who study at the dental department and young male students from non-medical departments $(32.84 \%)$.

The students have certain negative effects of alcohol abuse. These primarily include problems with parents, hangover and academic regress. A few students had problems with the police.

At the same time, more than half of the polled students realize the negative effect of alcohol on health and this includes $70.65 \%$ of young male students and $60.66 \%$ of young female students who study at the dental department, $62.75 \%$ of young male students from the medical department and $61.19 \%$ of young male students who study at non-medical departments.

The next step of our research was the study of student's reasons for alcohol use. The results are shown in table 6 .

Based on the data from table 6 it is possible to state that for medical department students in $37.39 \%$ of cases (young females) the cause of alcohol use is certain events celebration, while for $18.63 \%$ of young male students of the same department the cause is riddance of problems. For $34.09 \%$ of young male students who study at the dental department the use of alcohol is a factor of having a good time, while for young female students of the same department the cause is the celebration of certain events in $24.59 \%$ of cases. The students of non-medical departments most often use alcohol to celebrate certain events: this is true for $20.89 \%$ of young males and $35.09 \%$ of young females. Roughly $10 \%$ of the subjects use alcohol socially. 
Table 6

The causes of alcohol beverages use

\begin{tabular}{|c|c|c|c|c|c|c|c|}
\hline \multicolumn{2}{|l|}{ Description } & \multicolumn{2}{|c|}{$\begin{array}{c}\text { Medical } \\
\text { Department, } \\
\text { p-217 }\end{array}$} & \multicolumn{2}{|c|}{$\begin{array}{c}\text { Dental } \\
\text { Department } \\
\text { p-105 }\end{array}$} & \multicolumn{2}{|c|}{$\begin{array}{c}\text { Other } \\
\text { Departments } \\
\text { p-124 }\end{array}$} \\
\hline & & abs & $\%$ & abs & $\%$ & abs & $\%$ \\
\hline \multirow{2}{*}{ Get rid of problems } & 1 & 19 & 18.63 & 6 & 13.64 & 7 & 10.45 \\
\hline & 2 & 8 & 6.96 & 5 & 8.19 & 3 & 5.26 \\
\hline \multirow{2}{*}{ Feel relaxed } & 1 & 17 & 16.67 & 5 & 11.36 & 6 & 8.96 \\
\hline & 2 & 12 & 10.43 & 7 & 11.48 & 7 & 12.28 \\
\hline \multirow{2}{*}{ Feel joy } & 1 & 9 & 8.82 & 5 & 11.36 & 9 & 13.43 \\
\hline & 2 & 11 & 9.56 & 7 & 11.48 & 4 & 7.02 \\
\hline \multirow{2}{*}{ Have fun } & 1 & 14 & 13.73 & 15 & 34.09 & 14 & 20.89 \\
\hline & 2 & 19 & 16.52 & 17 & 27.87 & 8 & 14.04 \\
\hline \multirow{2}{*}{ Feel friendly } & 1 & 7 & 6.86 & 3 & 6.82 & 7 & 10.45 \\
\hline & 2 & 13 & 11.30 & 5 & 8.19 & 4 & 7.02 \\
\hline \multirow{2}{*}{$\begin{array}{c}\text { To keep other } \\
\text { people's company }\end{array}$} & 1 & 12 & 11.76 & 3 & 6.82 & 7 & 10.45 \\
\hline & 2 & 9 & 7.83 & 5 & 8.19 & 4 & 7.02 \\
\hline \multirow{2}{*}{$\begin{array}{c}\text { To celebrate certain } \\
\text { events }\end{array}$} & 1 & 15 & 14.71 & 7 & 15.91 & 14 & 20.89 \\
\hline & 2 & 43 & 37.39 & 15 & 24.59 & 20 & 35.09 \\
\hline \multirow{2}{*}{ Physical need } & 1 & 9 & 8.82 & - & - & 3 & 4.48 \\
\hline & 2 & - & - & - & - & - & - \\
\hline
\end{tabular}

Note: 1-young males, 2 - young females.

At the end of the study, the issue of affordability/availability of cigarettes, alcohol and drugs was studied. Table 7 states the results based on "easily available/affordable" and "rather easily available/affordable" answers.

Table 7

Availability of cigarettes, alcohol and drugs (sum total of "easily available/affordable" and "rather easily available/affordable" answers)

\begin{tabular}{|c|c|c|c|c|c|c|c|}
\hline \multirow{2}{*}{\multicolumn{2}{|c|}{ Description }} & \multicolumn{2}{|c|}{$\begin{array}{c}\text { Medical } \\
\text { Department, } \\
\text { p-217 }\end{array}$} & \multicolumn{2}{|c|}{$\begin{array}{c}\text { Dental } \\
\text { Department } \\
\text { p-105 }\end{array}$} & \multicolumn{2}{|c|}{$\begin{array}{c}\text { Other } \\
\text { Departments } \\
\text { p-124 }\end{array}$} \\
\hline & & abs & $\%$ & abs & $\%$ & abs & $\%$ \\
\hline \multicolumn{2}{|l|}{1} & 2 & 3 & 4 & 5 & 6 & 7 \\
\hline \multirow{2}{*}{ Cigarettes } & 1 & 102 & 100.0 & 44 & 100 & 67 & 100 \\
\hline & 2 & 115 & 100.0 & 61 & 100 & 57 & 100 \\
\hline \multirow{2}{*}{ Beer } & 1 & 102 & 100.0 & 44 & 100 & 67 & 100 \\
\hline & 2 & 115 & 100.0 & 61 & 100 & 57 & 100 \\
\hline \multirow{2}{*}{ Wine, sparkling wine } & 1 & 102 & 100.0 & 44 & 100 & 67 & 100 \\
\hline & 2 & 115 & 100.0 & 61 & 100 & 57 & 100 \\
\hline \multirow{2}{*}{ Low-alcohol beverages } & 1 & 97 & 95.10 & 44 & 100 & 67 & 100 \\
\hline & 2 & 115 & 100.0 & 61 & 100 & 57 & 100 \\
\hline \multirow{2}{*}{ Strong alcohol } & 1 & 100 & 98.04 & 44 & 100 & 67 & 100 \\
\hline & 2 & 109 & 94.78 & 61 & 100 & 57 & 100 \\
\hline
\end{tabular}


Continuation of Table 7

\begin{tabular}{|c|c|c|c|c|c|c|c|}
\hline $\mathbf{1}$ & $\mathbf{2}$ & $\mathbf{3}$ & $\mathbf{4}$ & $\mathbf{5}$ & $\mathbf{6}$ & $\mathbf{7}$ & $\mathbf{8}$ \\
\hline \multirow{2}{*}{ Marijuana or hashish } & 1 & 41 & 40.19 & 15 & 34.09 & 14 & 20.89 \\
\cline { 2 - 8 } & 2 & 21 & 18.27 & 11 & 18.03 & 7 & 12.28 \\
\hline \multirow{2}{*}{ Amphetamine } & 1 & 32 & 31.37 & 13 & 29.55 & 12 & 17.91 \\
\cline { 2 - 8 } & 2 & 19 & 16.52 & 7 & 11.47 & 5 & 8.77 \\
\hline \multirow{2}{*}{$\begin{array}{c}\text { LCD or other } \\
\text { hallucinogens }\end{array}$} & 1 & 30 & 29.41 & 11 & 25.00 & 13 & 19.40 \\
\hline \multirow{2}{*}{$\begin{array}{c}\text { Tranquilizers } \\
\text { or other sedatives }\end{array}$} & 1 & 15 & 13.04 & 12 & 19.67 & 8 & 14.04 \\
\hline \multirow{2}{*}{ Ecstasy } & 2 & 13 & 33.33 & 9 & 20.45 & 11 & 16.42 \\
\hline & 2 & 47 & 46.01 & 21 & 47.73 & 22 & 32.84 \\
\cline { 2 - 8 } & 2 & 32 & 27.83 & 23 & 37.70 & 14 & 24.56 \\
\hline
\end{tabular}

Note: 1-young males, 2 - young females.

The research results from table 7 demonstrate that practically for all the polled students, cigarettes, beer, low-alcohol beverages, wine, sparkling wine and strong alcohol are fully affordable. The students also noted a high accessibility/affordability level of ecstasy, tranquilizers and other sedatives, as well as LSD or other hallucinogens.

\section{CONCLUSIONS}

Based on the results of the sociological study, which covered 446 students of medical, dental and non-medical departments, it was discovered that despite the high level of awareness, the students follow lifestyles, which do not help maintaining and improving their health.

The key problems are alcohol intake, irrational nutrition, lack of sleep and insufficient physical activity. This requires shaping modern methods of prevention and forming the students' responsible attitude towards their own health.

\section{SUMMARY}

The results of sociological study of 446 students of different years and departments of Uzhhorod National University and Ukrainian Dental Academy. The poll covered 217 medical department students (102 young males and 115 young females), 105 dental department students (44 young males and 61 young females) and 124 students of non-medical departments (67 young males and 57 young females).

The poll results witness a rather high awareness of students with regard to healthy lifestyle, safe behavior and health maintaining technologies. At the same time, the awareness of medical and dental students with regard to the said issues is higher than the awareness of the students of non-medical departments.

It was found that significant quantity of students lead lives, which do not help to maintain or improve their personal health. For instance, $52.27 \%$ of 
young male students of dental department, and $42.11 \%$ of young females and $40.29 \%$ of young males from non-medical sleep less than 4 hours a day. More than $70 \%$ of all departments regardless of their gender have wrong diets, both with regard to meals time and to foods range (except for young female students of medical department, who violate diet rules in $49.56 \%$ of cases). At the same time, more that $60 \%$ of all polled students use sweet carbonated beverages. All the polled students have insufficient physical activity. Less than $25 \%$ of all the polled students exercise daily, except for young male students from dental department, where $27.27 \%$ exercise daily. Regardless of department and gender, less than $30 \%$ of the polled students visit gym or swimming pool.

It was found that roughly $70 \%$ of the polled students had intercourse over the past 12 month prior to the poll. Most of the subjects have one sex partner. Three and more sex partners were reported by $34.38 \%$ of young males, who study at the dental department and $15.79 \%$ young male students, who study at non-medical departments. At the same time, only about $70 \%$ of subjects use condoms all the time during sexual intercourse.

Over the past 30 days, more than $90 \%$ of the polled subjects from medical departments and young male students from non-medical departments had alcohol. The lowest percentage of subjects who drank alcohol over the past 30 days was among dental students: $68.18 \%$ of young males and of $60.66 \%$ young females. In general, young male students prefer beer and strong drinks, while young females prefer wine/sparkling wine.

Out of those who used alcohol over the past 30 days most often reported intoxication was among young males $(70.45 \%)$ and young females $(31.15 \%)$, who study at the dental department and young male students from non-medical departments (32.84\%).

All students stated high accessibility level of cigarettes, alcohol and some other psychoactive substances.

The poll data form basis for modern prevention approaches formation and for shaping the students' responsible attitude towards their own health.

\section{REFERENCES}

1. Grebnyak N.P. Zdorov'e i obraz zhizni studentov / N.P. Grebnyak, V.P. Grebnyak, V.V. Mashinistov // Problemy sotsial'noy gigieny, zdravookhraneniya i istorii meditsiny. - 2007. - № 4. - S. 33-37.

2. Hooper L., Abdelhamid A., Moore H.J., Douthwaite W., Skeaff C.M., Summerbell C.D. Effect of reducing total fat intake on body weight: systematic review and meta-analysis of randomised controlled trials and cohort studies. British Medical Journal, 2012, no. 12, P. 12-15.

3. Baklykova A.V. Zdorov'e i obraz zhizni studentov-medikov // Molodoy uchenyy. - 2010. - № 5. T. 2. - S. 205-207. 
4. Sadvakasov T.M. Sravnitel'naya kharakteristika obraza zhizni lits molodogo vozrasta // T.M. Sadvakasov, Sh.D. Dzhaketaeva, G.A. Zhanalina, Zh.A. Aldanova, K.T. Abdrakhmanov, T.S. Sergaliev, D.B. Kulov // Meditsina i ekologiya. - 2015. - № 1(74). - S. 46-47.

5. Shagina I.R. Vliyanie uchebnogo protsessa na zdorov'e studentov // Astrakhanskiy meditsinskiy zhurnal. - 2010. - № 2. - S. 26-29.

6. Fats and fatty acids in human nutrition: report of an expert consultation. Food and Agricultural Organization of the United Nations / FAO Food and Nutrition. - Rome, Italy. - 2010. - P. 91.

7.Diet, nutrition and the prevention of chronic diseases: report of a Joint WHO/FAO Expert Consultation. World Health Organization - WHO Technical Report Series, No. 916. - Geneva, Switzerland, - 2003.

8. Gharkusha C.V. Kharakterystyka stanu zdorov'ja suchasnoji molodi v Ukrajini. Visnyk Chernigh. nac. ped. un-tu im. T.Gh. Shevchenka. Ser.: ped. nauky. Fiz. vykh. i sport. ChNGhGhU. 2013;1(107):92-5.

9. Ponomareva L.A. Analiz urovnya zdorov'ya studentov-medikov / L. A. Ponomareva, S. I. Dvoynikov // Zdorov'e sem'i XXI vek: mater. VI Mezhdunar. nauch. konf. - Perm', 2002. - S. 111-112.

10. Popkova O. S. Sotsial'no-gigienicheskie osobennosti formirovaniya zdorov'esberegayushchego povedeniya u studentov // Molodoy uchenyy. 2015. - №6.4. - S. 44-46. - URL https://moluch.ru/archive/86/16378/ (data obrashcheniya: 09.11.2019).

11. Zhdanova O.V. Rivenj internet-zalezhnosti studensjkoji molodi (za danymy sociologhichnogho doslidzhennja)/ O.V. Zhdanova, Gh.O.Slabkyj // Ukrajina. Zdorov'ja naciji. 2019. - \#2. - S.55-58

12. Baklykova A.V. Zdorov'e i obraz zhizni studentov-medikov. Molodoy uchenyy. 2010;5:205-7.

13. Ushakova Ya.V. Zdorov'e studentov i faktory ego formirovaniya/Ya.V. Ushakova // Vesnik Nizhegorodskogo universiteta im. N.I. Lobacheskogo. 2017. - №4 - S.197-202

14. Zhuravleva I.V., redaktor. Zdorov'e studentov: sotsiologicheskiy analiz. Institut sotsiologii RAN. Moskva; 2012. $252 \mathrm{~s}$.

\section{Information about the author:} Zhdanova O. V., orcid.org/0000-0002-4229-4604 Post-Graduate Student of Health Sciences

Uzhhorod National University 29, Mytna str., 88000, Uzhhorod, Ukraine 


\section{STATE OF READINESS FOR THE HEALTH SYSTEM OF UKRAINE FOR IMPLEMENTATION OF A NEW MODEL OF REHABILITATION AID}

\section{Myronyuk I. S.}

\section{INTRODUCTION}

The World Health Organization (WHO) believes that rehabilitation services are a public health strategy that is largely targeted at specific people and can be implemented through specific rehabilitation programs (typically for people with disabilities) or integrate into other health sector programs and services, such as primary health care programs, psychiatric, ophthalmic, or cardiac care ${ }^{1}$. Today, the situation in Ukraine is a complete reboot of the entire healthcare system. Thus, there are parallel processes of systemic changes both in the system of providing medical care to the population ${ }^{2}$, as well as in the process of creating and becoming a public health system of Ukraine $^{3}$ and a new system of providing rehabilitation assistance to the population. In different sectors of the health care system, reforms are being implemented at different speeds and, naturally, there are situations where reforms in one component of the country's health and safety sector are slightly ahead of the changes in the other one. So, in Ukraine, systematic changes in the organization of provision of medical care to the population at the primary level have been practically introduced: a new financing model has been formed, changes in the organization of work have been introduced, and basic functions of family medicine and general practice have been outlined. At the same time, rehabilitation services, medical, physical, and other types of rehabilitation, both at the primary level of medical care and at the level of territorial communities, are currently under

\footnotetext{
${ }^{1}$ Rehabilitation. Key facts. WHO global website [Electronic resource]. Retrieved from: https://www.who.int/ru/news-room/fact-sheets/detail/rehabilitation

2 Про державні фінансові гарантії медичного обслуговування населення: Закон України (2018). Відомості Верховної Ради (ВВР), № 5, ст. 31

3 Про схвалення Концепції розвитку системи громадського здоров'я (2016): розпорядження Кабінету Міністрів України. [Електронний ресурс] - Режим доступу: https://www.kmu.gov.ua/npas/249618799
} 
development ${ }^{4}$. In 2015, a WHO Mission worked in Ukraine to assess the state of rehabilitation assistance to the country's population. Mission experts have made it clear that Ukraine needs to implement a National Plan on Limitation of Life, Health and Rehabilitation that would, in particular, address a number of problems of non-compliance of the existing rehabilitation system in the country with international standards ${ }^{5}$. Yes, it has been determined that the very concept and understanding of «disability» does not correspond to a modern and internationally agreed understanding of the limitations of life and function; legislation and by-laws on rehabilitation in Ukraine are fragmented, there is a lack of coordination between authorized ministries and organizations; there is no holistic system of rehabilitation services covering all phases and levels of assistance; rehabilitation services are not available to many people in need; staffing for rehabilitation does not meet world and European standards. At the same time, WHO itself recognizes that Ukraine's listed problems in rehabilitation are not purely Ukrainian and are characteristic of many countries. Thus, the unresolved global rehabilitation tasks are due to the fact that the current demographic trends and the dynamics of the population's health indicators place new tasks before the health care system, and therefore the need for rehabilitation services is increasing. The proportion of the elderly is increasing in the population structure and it is projected that by 2050 the proportion of people over 60 will double. In addition, more people are living with non-communicable diseases and the effects of various injuries. The prevalence of non-communicable diseases alone has increased by $18 \%$ over the last 10 years. Most often, these disorders limit the functionality of the individual and contribute to the growth of disability $^{6}$. Since the recommendations and conclusions of the WHO Special Mission have been made public, a considerable period of time has passed, and the rehabilitation system in Ukraine is progressing slowly and needs to be implemented in practical health care.

\footnotetext{
${ }^{4}$ Деякі питання реалізації державних гарантій медичного обслуговування населення за програмою медичних гарантій для первинної медичної допомоги на 2019 рік (2018): постанова Кабінету Міністрів України. [Електронний ресурс] - Режим доступу: https://zakon.rada.gov.ua/laws/show/1117-2018-\%D0\%BF

${ }^{5}$ Оцінка системи реабілітації в Україні. Основні висновки. - Оціночна місія ВООЗ. Грудень 2015. -[Електронний ресурс]. - Режим доступу: https://physrehab.org.ua/wpcontent/uploads/docs/Assessment\%20of\%20the\%20Rehabilitation\%20System\%20in\%20Ukrai ne.\%20Summary\%20rstr\%20UKR.pdf

${ }^{6}$ Див 1.
} 


\section{Legal regulation of the rehabilitation assistance system in Ukraine: the state of the issue}

The legal framework for the rehabilitation assistance system is fragmented and not in line with the international commitments made by Ukraine, namely the Convention on the Rights of Persons with Disabilities, which entered into force for Ukraine in March 2010 ${ }^{7}$. Thus, the Law of Ukraine, which regulated the whole system of providing rehabilitation assistance in the country (the Law of Ukraine «On Rehabilitation of Persons with Disabilities in Ukraine») in the 2005 version, extended exclusively to persons with disabilities and did not take into account the need to provide rehabilitation services to persons immediately after the acquisition of impaired health in order to prevent the actual fact of disability ${ }^{8}$. Some changes have been made to this version of the Law. Thus, in 2011, in order to fulfill the requirements for implementation of the UN Convention on the Rights of Persons with Disabilities, the Law of Ukraine «On Rehabilitation of Persons with Disabilities in Ukraine» was amended to define the terms «disabled», «disabled child» and «disability». Emphasis was placed not on the state of health of the individual, but on the establishment of a close link between the person with health disorders and obstacles in society, which could lead to a limitation of life of such person. Since the beginning of the armed conflict in eastern Ukraine, this Law was amended in 2014, in particular by categories of persons who may have needed rehabilitation services as a result of an anti-terrorist operation. With some modifications, the Act now extends to 16 additional categories of persons. Consequently, without changing the approach to rehabilitation and leaving the existing structure of rehabilitation services for people with disabilities, it simply added 16 categories of persons with health disabilities resulting from the armed conflict. Positive is the formal extension of the service to obtain technical and other means of rehabilitation, means of medical appointment to the victims of the armed conflict, disability which has not been established ${ }^{9}$. But such point changes in the basic state regulatory system of rehabilitation of the act could not shift from the «dead point» the process of

\footnotetext{
${ }^{7}$ Конвенція про права осіб з інвалідністю (Конвенція про права інвалідів): Верховна рада України. [Електронний ресурс] - Режим доступу: https://zakon.rada.gov.ua/laws/ show/z0417-19

${ }^{8}$ Про реабілітацію інвалідів в Україні: Закон України. Відомості Верховної Ради України (BBP), 2006, N2-3, ст. 36. [Електронний ресурс] - Режим доступу: http://zakon.rada.gov.ua/laws/show/2961-15

9 Мойса Б., Павліченко О., Мартиненко О. Реабілітація жертв конфлікту. Чи пропонує держава щось, крім встановлення інвалідності та милиць? Українська Гельсінська спілка з прав людини. К., 2018. 64 с.
} 
reforming the system. Therefore, in 2016 a draft law was submitted by the deputy group for consideration by the Verkhovna Rada of Ukraine, which regulates the activity of the rehabilitation assistance system - the draft law of Ukraine of April 15, 2016 No. 4458 "On Disability Prevention and Rehabilitation System in Ukraine" definition of terms has already been significantly expanded as a list of basic concepts, so their interpretation is adjusted in accordance with generally accepted international standards. The categories of persons covered by the Law have been expanded, including citizens of Ukraine and foreigners in need of rehabilitation services. Although this draft Law of Ukraine has not been adopted, it envisaged many significant innovations. In 2017, the President of Ukraine submitted another Draft Law of Ukraine, namely, "On the Rehabilitation System in Ukraine" "11. In addition to the introduction of new concepts in accordance with international standards - «physical therapy», «ergotherapy» and others, this draft legislative act contains key provisions that refer to persons in need of rehabilitation: 1) persons with lifelimitation; 2) persons, whose illnesses, injuries, or birth defects can lead to permanent loss of life.

At the same time, while the central legislative body of Ukraine is considering draft laws on the regulation of the rehabilitation assistance system in the country, the central executive authorities are actively implementing the normative regulation of providing rehabilitation assistance to the population according to international standards. Thus, the start of the implementation of the Plan of Measures for Implementation of the International Classification of Functioning, Life and Health Limitations and the International Classification of Functioning, Limitation of Life and Health of Children and Adolescents approved by the Decree of the Cabinet of Ministers of December 28, 2017 \# 288 On its implementation by the Ministry of Health of Ukraine by the order of May 25, 2018 under No. 981 approved the official translation of the International Classification of Functions, Limitations and International Classification of Functioning, Life and Health Limitations of Children and Adolescents.

The first decisive step towards significant changes in the system of rehabilitation assistance to the population was the introduction by the Ministry of Economic Development and Trade of Ukraine of amendments to

\footnotetext{
${ }^{10}$ Про попередження інвалідності та систему реабілітації в Україні: проект Закону України [Електронний ресурс] - Режим доступу: http://search.ligazakon.ua/1_doc2.nsf/link1/ JH3FU00A.html

${ }^{11}$ Про систему реабілітації в Україні: проект Закону України [Електронний ресурс] Режим доступу: https://novynarnia.com/2017/10/02/zakon-ukrayini-pro-sistemu-reabilitatsiyiv-ukrayini-proekt/
} 
the National Classifier of Ukraine DK 003: 2010 "Classifier of professions". In particular, by Amendment \# 5 the following professions were officially introduced to the classifier in Ukraine: 2221.2 "Physician of Physical and Rehabilitation Medicine"; 2229.2 Physical Therapist and 2229.2 Ergotherapist. By this document, these professions have been formally formalized in Ukraine.

Another important step in building a rehabilitation system for the population was to identify new professions, for example, in 2017, the Ministry of Health of Ukraine introduced changes to the Handbook of qualification characteristics of workers' professions. Issue 78 «Health Care», «Professionals» section introduced the following professions: Physical and Rehabilitation Physician, Physical Therapist and ergotherapist. In 2018, the list has also been supplemented by the professions of Physical Therapist Assistant and Occupational Therapist Assistant, which have been added to the Specialists section ${ }^{12}$. This normative document of the Ministry of Health of Ukraine regulates the tasks and duties of health professionals. Important is the fact that this order provides qualification categories not only for the medical profession - physician of physical and rehabilitation medicine, but also for physical therapists / ergotherapists and their assistants. The implementation of this provision is important and promising, since it creates the basis for the introduction of a system of continuous professional development and continuous training of physical therapists, ergotherapists and their assistants by analogy with a similar system introduced in the country for doctors. At the same time, at present, the system of postgraduate education, training and certification of both physical therapists / ergotherapists and assistants of the physical therapist or ergotherapist has not been developed in the country.

Thus, at the beginning of 2019, Ukraine has practically created a base for staffing the updated system of rehabilitation assistance to the population at all levels of health care assistance. However, the introduction of new posts in budgetary health care institutions was formally hindered by the provisions of the Ministry of Health of Ukraine Regulations No. $385^{13}$ of October 28, 2002. This order determined the list of health care institutions, medical, pharmacist and pharmacy specialist who obtain education in health care institutions. The head of the budget health care institution may not enter in

12 Про внесення змін до Довідника кваліфікаційних характеристик професій працівників. Випуск 78 «Охорона здоров’я»: наказ МОЗ України від 13.12.2018 № 2331. [Електронний ресурс] - Режим доступу: https://zakon.rada.gov.ua/rada/show/v2331282-18

${ }^{13}$ Про внесення змін до наказу Міністерства охорони здоров'я України від 28 жовтня 2002 року № 385: наказ МОЗ України від 25.03.2019 № 668. [Електронний ресурс] Режим доступу: https://zakon.rada.gov.ua/laws/show/z0417-19 
the staff list of the institution the positions that are not provided in the list. Therefore, in March 2019, it was formalized the possibility of entering the positions of the said specialists (physicians and rehabilitation doctors, physical therapists / ergotherapists and their assistants) in the health care institutions of Ukraine by amending the relevant regulatory order of the Ministry of Health of Ukraine of October 28, 2002 № 385. Today, health care managers of all forms of ownership and of all levels of care can enter these positions in the staffing lists of institutions. The central executive body also took into account the specific features of the training of rehabilitation specialists that existed in Ukraine until recently. Thus, until February 1, 2017, specialists were trained in the system of rehabilitation assistance in the field of knowledge 0102 Physical education, sports and human health and specialties (areas of training) of human health, physical rehabilitation and fitness and recreation. The diplomas of bachelors, masters, who completed their studies in these specialties or areas, indicated, in particular, a specialist in physical rehabilitation (often in conjunction with the qualification of a coach for the chosen sport or physical education teacher). Of course, finding a graduate with such a diploma in health care was problematic, and they mostly implemented themselves in the system of rehabilitation assistance in the existing positions of massage nurses or instructors of physical therapy in sanatorium establishments. Changes in the training of specialists at higher educational establishments of Ukraine began only in 2017, when the Decree of the Cabinet of Ministers of Ukraine of February 01, 2017 No. 53 introduced changes to the list of fields of knowledge and specialties for which higher education applicants are trained in Ukraine.

Namely, in the field of knowledge 22; Health care introduced the specialty 227 «Physical therapy. Ergotherapy». Therefore, in view of such peculiarities of training of specialists in physical rehabilitation, which have existed in Ukraine until recently, the Ministry of Health of Ukraine issued a separate clause in the order No. $668^{14}$ of 25.03 .2019 , granting employment for the positions of physical therapists, ergotherapists and their assistants, specialists and bachelor specialists educated in the specialty «Physical Rehabilitation» and the direction of preparation «Human Health». At the same time, it should be kept in mind that the employment of persons with a diploma qualification as a specialist in physical rehabilitation is possible provided they have completed their specialization in physical therapy within five years from the moment of employment.

Ukraine's education system, in particular higher education, has also responded quickly to the need to build a new rehabilitation system in the

${ }^{14}$ Там само. 
country. Thus, in addition to introducing new specialties for higher education applicants, the Ministry of Education and Science of Ukraine has developed, publicly discussed and implemented a new Higher Education Standard of Ukraine: first (bachelor) level, field of knowledge 22 «Health», specialty 227 «Physical Therapy, ergotherapy «. The relevant standard of master's training has already been publicly discussed and is undergoing approval and signing.

Thus, today in Ukraine, a sufficient list of legal and regulatory documents has been practically developed and put into effect to launch a new model of rehabilitation assistance to the population, which should affect both the health indicators of the population as a whole and the reduction of the levels of disability of the Ukrainian population that exceed similar figures in most countries today ${ }^{15}$.

\section{Assessment of the readiness of the practical system of providing medical assistance to the population}

\section{for the implementation of the new system of rehabilitation assistance}

In our opinion, assessing the readiness of the existing system of providing medical care to the population of Ukraine, as a practical component of the health care system, for the implementation of new approaches to providing rehabilitation care can be based on different approaches. First of all, it should be noted that there are already a number of health care facilities in the country where processes of introducing new approaches to providing rehabilitation assistance to different categories of population are taking place. These are mainly specialized rehabilitation centers of different ownership forms, separate departmental health institutions of the Ministry of Defense of Ukraine and some others. At the same time, against the backdrop of the entire health care system in the country, these facilities should most likely be considered as exceptions to the rule. The system's readiness to innovate can also be approached differently and from different perspectives. In particular, it is possible to assess the readiness of the material base and, probably, in the vast majority of health facilities located in small settlements, it will not be sufficient. At the same time, the weak material and technical base, in our opinion, is not the main obstacle to the rapid implementation of the updated system of rehabilitation care at different levels of health care delivery to the population.

${ }^{15}$ Слабкий Г.О. Шафранский В.В. Дудіна О.О. (2016) Інвалідність дітей як проблема громадського здоров'я: профілактика та забезпечення ефективної реабілітації. Вісник соц. гігієни та організації охорони здоров’я України. № 3 (69). С. 27-30. 
More important at this stage of establishing a new rehabilitation care system as part of the health care delivery system, in particular, is the willingness of health care managers and health care professionals to cooperate with physical and medical rehabilitation specialists at all stages of health care assistance and availability of such specialists is sufficient at labor market. These are the very aspects that play a key role in determining the location and form of rehabilitation care in health care facilities in the early stages of the new health care system in Ukraine. For all professionals, the problem of staffing the rehabilitation assistance system remains a significant one. Staffing is now needed in large numbers to ensure the process of patient rehabilitation in healthcare settings. Each patient at the most intensive, subacute, rehabilitation stage should receive three hours of individual training daily with a physical therapist, an ergotherapist, or other functional specialist in a multidisciplinary team.

On the one hand, it is necessary to build (reload) high-quality national education of relevant specialists very quickly. On the other hand, work out procedures for regulating new healthcare professionals who, even while working in health care institutions, did not have their own official positions there.

The question of how to organize a rehabilitation service the best has been debated for a long time. Some countries have programs that set up specialized rehabilitation departments (specialized approach). Other countries have emphasized improving the training of medical students through integrated training in rehabilitation methods in combination with the preventive and curative aspects of disability. This approach aims to encourage all physicians to undertake rehabilitation as an integral part of their daily work (non-specialized approach). It should be noted that both specialized and non-specialized approaches have proven to be viable. Therefore, both approaches should be used in the reorganization of medical care and training in higher education institutions in Ukraine ${ }^{16}$.

The problem of saturation of the labor market by trained specialists in physical and medical rehabilitation in the first stages will be one of the decisive ones. Indeed, in 2017, the higher education system of Ukraine launched the first bachelor's degree in the specialty 227. Physical therapy. Ergotherapy. These specialists may be employed employed in the future as Physical Therapist Assistants (ergotherapist assistants) or continue their Master's Degree in a specialty or 227.1. Physical therapy or 227.2.

${ }^{16}$ Мисула І.Р., Голяченко А.О., Бакалюк Т.Г., Зятковська О.Я., Завіднюк Ю. В., Сірант Г. О. (2018) Шляхи вдосконалення викладання медичної реабілітації в сучасних умовах. Медична освіта. № 1. С. 39-42. 
Ergotherapy. So, the first bachelor's degree in specialty 227.Physical therapy. Ergotherapy is expected in Ukraine only in 2021. At the same time, this is not a significant problem, because today, firstly, the posts of assistants to the physical therapist or ergotherapist in health care institutions are practically not introduced, secondly: if such a position is introduced by the head of the health care institution, he may not accept a full-time bachelor's degree in physical rehabilitation, which has been produced in Ukraine for quite some time. The first issues of masters of physical therapy and ergotherapy, as well as specialization of doctors in the specialty «physician of physical and rehabilitation medicine» in Ukraine have already taken place. Of course, the number of trained specialists in these specialties will not meet all the needs of healthcare institutions. However, today there is another problem - it is the formation of a range of vacancies for rehabilitation professionals in healthcare facilities.

Of course, sanatorium establishments, which traditionally operate in the market of rehabilitation and rehabilitation treatment services, have gradually started to enter the positions of relevant specialists in the staff lists. At the same time, health care facilities that provide emergency and planned medical care in the attached territories are practically unplanned. This situation is caused by the considerable level of uncertainty of the work of such institutions in the conditions of reformation of the secondary and tertiary level of providing medical care, which is currently actively implemented in the country. Yes, the transition of health care institutions to new forms of management (transition from municipal (state) institutions to the status of medical non-profit enterprises), change of the principle of financing: for the rendered medical services and treated cases, and not for the maintenance of the institution is a challenge for the effective functioning of each a separate institution in the new environment. Therefore, reorganizing the work of the institution through the re-profiling of departments, positions and directions of rendering medical (and rehabilitation) services in such conditions is considered by managers to be quite risky ${ }^{17}$.

However, the situation may change dramatically in the nearest future. Namely, from January 1, 2020 in connection with the implementation of the full scope of the Health Guarantee Program, which is being implemented in Ukraine for the implementation of the Law of Ukraine "On State Financial Guarantees of Public Health Services". Thus, the National Health Service of Ukraine will purchase medical services in health care facilities of all levels

17 Богдан Д., Бойко А., Василькова А., Вежновець Т., Звінчук О., Латипов А., Миронюк І., та ін. (2019) Кадрові ресурси системи охорони здоров'я в Україні. Ситуаційний аналіз / Київ: Проект USAID «Підтримка реформи охорони здоров'я» 133 с. 
of care, organizational and legal form (except budgetary institution) and form of ownership and pay for them under the contract. The procurement procedure for medical services will require providers to comply with the terms of service and specifications for specific services / groups of services. The important fact is that rehabilitation services (both medical and physical rehabilitation) are provided for in the vast majority of packages of medical services that will be purchased by the National Health Service of Ukraine for budgetary funds ${ }^{18}$. In addition to 2020 , the purchase of medical services under the package «Medical Rehabilitation» is also envisaged. The requirements for the Medical Rehabilitation Package include the provision of inpatient or outpatient medical rehabilitation to patients with diseases in the recovery period, that is, beyond the acute period, in particular:

- adults and children from three years of age with disorders of the nervous system;

- adults and children from three years old with impaired function of the musculoskeletal system;

- children born prematurely and / or ill during the first three years of life.

Medical rehabilitation services for patients in the acute period of the disease are provided in packages of services provided in the inpatient setting and will, accordingly, be paid according to the treated case.

Importantly, there are clear requirements for the logistics and staffing of each paid service package. For example, the package «Medical Rehabilitation / Rehab for Infants Who Have Been Prematurely and / or Sick during the First Three Years of Life» provides the following requirements for staffing the healthcare facility for that package to receive payment for its delivery.

\section{Requirements for specialization of medical workers:}

1. Pediatrician; at least two people working in the main place of work in one institution.

2. Physician holding a valid certificate of a specialist of a doctor in the field of specialization: physician in physical and rehabilitation medicine, physical therapist, ergotherapist, physician in therapeutic exercise and sports medicine - at least two people working at the main place of work in this institution.

3. Physical Therapist Assistant - at least two people working in the main place of work in this institution.

4. Assistant ergotherapist - at least two people who work at the main place of work in this institution.

\footnotetext{
${ }^{18}$ Вимоги ПМГ 2020. Національна служба здоров'я України. [Електронний ресурс] Режим доступу: https://nszu.gov.ua/likar-2020
} 
5. Speech therapist for conducting neurorehabilitation activities for adults and children - at least two people working in the main place of work in this institution.

6. Psychologist - at least two persons who work at the main place of work in this institution.

7. Pediatric ophthalmologist (according to the concluded contracts).

8. Physician-surgeon (in accordance with the concluded contracts).

9. A medical nurse practicing in physical education, or a nurse practitioner who has received training in medical rehabilitation and has received a qualification in the specialty «Physical rehabilitation» or has acquired additional knowledge in the specialization in nursing in medical rehabilitation ${ }^{19}$.

Therefore, secondary and tertiary (specialized and highly specialized) pediatric hospitals will need to be staffed in the near future by staff members: both physical and rehabilitation physicians, physical therapists, ergotherapists and their assistants. There is a clear requirement for each of the specialties: at least two persons working in the main place of work in this institution.

Similarly, clear requirements for staffing of rehabilitation care professionals are laid down in the requirements for the provision of packages of secondary and tertiary (highly specialized) medical care for common diseases and pathological conditions, which is provided in almost all multidisciplinary health care establishments. For example, in the package of medical services «Medical Assistance for Acute Stroke» the following requirements for specialization of medical workers are given:

1. Neuropathologist having adequate training in the provision of medical assistance for acute stroke - not less than 4.75 full-time positions (around the clock).

2. Anesthesiologist - at least 4.75 full-time positions (around the clock).

3. Physical and Rehabilitation Physician / Physical Therapist / ergotherapist / Physical Education Physician / Sports Medicine Physician at least 2 full-time members of staff at this institution.

4. Speech therapist (language and speech therapist) - at least one person working in the main place of work in this institution (preferably).

5. Nurse - no less than 4.75 full-time positions (around the clock) for every 4 beds where patients with acute stroke are hospitalized.

Based on the above, virtually all health care institutions, regardless of the level of care, specialization and ownership in the near future, will need to equip jobs and recruit specialists for rehabilitation care in various specialties. Of course, if this institution wants to apply for budgetary funds for medical

${ }^{19}$ Вимоги ПМГ 2020. Національна служба здоров'я України. [Електронний ресурс] Режим доступу: https://nszu.gov.ua/likar-2020 
and rehabilitation services. If the planned innovations are implemented, all the conditions will be in place in the country for the rapid and effective development of a new rehabilitation assistance system as an integral part of Ukraine's health care system.

\section{CONCLUSION}

Subsequent to the work of the WHO Assessment Mission (2015), which assessed the state of rehabilitation assistance to the country's population and concluded that the system of rehabilitation assistance in Ukraine did not meet international standards, significant changes had taken place. Today, through the efforts of central executive bodies, national agencies and the expert environment in Ukraine, a sufficient list of regulatory documents has been practically developed and put in place to launch a new model of the system of rehabilitation assistance to the population. Thus, new professions of rehabilitation specialists were introduced (physician of physical and rehabilitation medicine, physical therapist, ergotherapist and assistants of the physical therapist and ergotherapist), conditions were created for the introduction of appropriate positions in the staff lists of educational institutions of health care, and the process of training of staff was started in Ukraine. At present, there are practically no legal barriers to the introduction of a new rehabilitation system in the country. The shortage of trained professionals and of the health care system staff at the level of health care institutions for the introduction of new posts and the development of the provision of rehabilitation services to the population may be overcome in the near future. The implementation of new conditions for payment of budgetary funds for the provision of medical services on the basis of packages of medical services of the National Health Service of Ukraine under the concluded contracts will force the health care institutions to fulfill the conditions of personnel and material support of these packages. Practically all of the offered packages of medical services provide rehabilitation services, which should be provided by full-time workers - specialists of rehabilitation assistance.

If the planned innovations are implemented, all the conditions will be in place in the country for the rapid and effective development of a new rehabilitation assistance system as an integral part of Ukraine's health care system.

\section{SUMMARY}

The paper presents the results of the assessment of the readiness of the health care system of Ukraine, including the system of providing medical assistance to the population, for the implementation of the new rehabilitation aid system. The analysis of the legal support of the functioning of the new system of rehabilitation assistance in accordance with international standards 
is carried out. Regulations of central executive bodies, ministries and institutions on the introduction of new professions of rehabilitation assistance specialists in the country and the conditions of their professional training and functioning have practically eliminated barriers to the introduction of a new rehabilitation assistance system in the country. The problems presented in the way of rapid implementation of the new system of rehabilitation assistance in the existing system of providing medical services to the population directly at the level of health care institutions of different levels of providing medical assistance to the population are presented. At the same time, the planned implementation in 2020 of new conditions for payment of budgetary funds for the provision of medical services on the basis of packages of medical services of the National Health Service of Ukraine under the concluded agreements will create favorable conditions for the rapid development of the rehabilitation assistance system at all levels of its provision.

\section{REFERENCES}

1. Rehabilitation. Key facts. WHO global website. Retrieved from: https://www.who.int/ru/news-room/fact-sheets/detail/rehabilitation_(accessed 12 November 2019)

2. Pro derzhavni finansovi harantii medychnoho obsluhovuvannia naselennia [On State Financial Guarantees of Medical Services to the Population] (2018): Zakon Ukrainy [Law of Ukraine]. Retrieved from: https://zakon5.rada.gov.ua/laws/show/2168-19 [in Ukrainian] (accessed 12 November 2019)

3. Pro skhvalennia Kontseptsii rozvytku systemy hromadskoho zdorovia (2016): rozporiadzhennia Kabinetu Ministriv Ukrainy. Retrieved from: https://www.kmu.gov.ua/npas/249618799 [in Ukrainian] (accessed 12 November 2019)

4. Deiaki pytannia realizatsii derzhavnykh harantii medychnoho obsluhovuvannia naselennia za prohramoiu medychnykh harantii dlia pervynnoi medychnoi dopomohy na 2019 rik (2018): postanova Kabinetu Ministriv Ukrainy. Retrieved from: https://zakon.rada.gov.ua/laws/show/ 1117-2018-\%D0\%BF [in Ukrainian] (accessed 12 November 2019)

5. Otsinka systemy reabilitatsii v Ukraini. Osnovni vysnovky [Assessment of the rehabilitation system in Ukraine. The main conclusions] (December 2015). WHO evaluation mission. Retrieved from: https://physrehab.org.ua/wp-content/uploads/docs/Assessment $\% 20$ of $\% 20$ the $\% 20$ Rehabilitation $\% 20$ System $\% 20$ in $\% 20$ Ukraine. $\% 20$ Summary\%20rstr\%20UKR.pdf_[in Ukrainian] (accessed 12 November 2019) 
6. Rehabilitation. Key facts. WHO global website. Retrieved from: https://www.who.int/ru/news-room/fact-sheets/detail/rehabilitation_(accessed 12 November 2019)

7. Konventsiia pro prava osib $\mathrm{z}$ invalidnistiu (Konventsiia pro prava invalidiv) [Convention on the Rights of Persons with Disabilities (Convention on the Rights of the disabled)] (2010). Retrieved from: https://zakon.rada.gov.ua/laws/show/995_g71 [in Ukrainian] (accessed 11 November 2019)

8. Pro reabilitatsiiu invalidiv $\mathrm{v}$ Ukraini [On Rehabilitation of Persons with Disabilities in Ukraine] (2006): Zakon Ukrainy [Law of Ukraine] Retrieved from: http://zakon.rada.gov.ua/laws/show/2961-15 [in Ukrainian] (accessed 11 November 2019)

9. Moysa B., Pavlichenko O., Martynenko O. (2018) Reabilitatsiia zhertv konfliktu. Chy proponuie derzhava shchos, krim vstanovlennia invalidnosti ta mylyts? Kyiv: Ukrainian Helsinki Human Rights Union [in Ukrainian].

10. Pro poperedzhennia invalidnosti ta systemu reabilitatsii v Ukraini [On Disability Prevention and Rehabilitation System in Ukraine] (2016, April 15): Proekt Zakonu Ukrainy [Draft Law of Ukraine] No. 4458. Retrieved from: http://search.ligazakon.ua/1_doc2.nsf/link1/JH3FU00A.html [in Ukrainian] (accessed 12 November 2019)

11. Pro systemu reabilitatsii v Ukraini [On the Rehabilitation System in Ukraine]: Proekt Zakonu Ukrainy [Draft Law of Ukraine]. Retrieved from: https://novynarnia.com/2017/10/02/zakon-ukrayini-pro-sistemureabilitatsiyi-v-ukrayini-proekt/ [in Ukrainian] (accessed 12 November 2019)

12. Pro vnesennia zmin do Dovidnyka kvalifikatsiinykh kharakterystyk profesii pratsivnykiv. Vypusk 78 «Okhorona zdorovia» 78 (2018): nakaz Ministerstva okhorony zdorovia Ukrainy [order of the Ministry of Health of Ukraine] № 2331. Retrieved from: https://zakon.rada.gov.ua/rada/show/ v2331282-18 [in Ukrainian] (accessed 12 November 2019)

13. Pro vnesennia zmin do nakazu Ministerstva okhorony zdorovia Ukrainy vid 28 zhovtnia 2002 roku № 385 [On amendments to the order of the Ministry of Health of Ukraine № 385 ( 2002, October 28)] : nakaz Ministerstva okhorony zdorovia Ukrainy [order of the Ministry of Health of Ukraine] № 668. (2019, March 25). Retrieved from: https://zakon.rada.gov.ua/laws/show/z0417-19 [in Ukrainian] (accessed 11 November 2019)

14. Pro vnesennia zmin do nakazu Ministerstva okhorony zdorovia Ukrainy vid 28 zhovtnia 2002 roku № 385 [On amendments to the order of the Ministry of Health of Ukraine № 385 ( 2002, October 28)] : nakaz Ministerstva okhorony zdorovia Ukrainy [order of the Ministry of Health of Ukraine] № 668. (2019, March 25). Retrieved from: 
https://zakon.rada.gov.ua/laws/show/z0417-19 [in Ukrainian] (accessed 11 November 2019).

15. Slabkiy G.O., Shafranskiy V.V., Dudina O.O. (2016) Invalidnist ditei yak problema hromadskoho zdorovia: profilaktyka ta zabezpechennia efektyvnoi reabilitatsii [Disability of children as a problem of public health: prevention and effective rehabilitation ]// Visnyk sots. hihiieny ta orhanizatsii okhorony zdorovia Ukrainy [Bulletin of Social Hygiene and Health Protection Organization of Ukraine] №3 (69). C. 27-30.

16. Misula IR, Golyachenko AO, Bakaliuk TG, Zyatkovskaya OY, Zavidnyuk Yu. V., Sirant GO. (2018) Shliakhy vdoskonalennia vykladannia medychnoi reabilitatsii $\mathrm{v}$ suchasnykh umovakh [Ways to improve the teaching of medical rehabilitation in modern conditions.]. Medychna osvita [Medical education]. № 1 c. $39-42$

17. Bohdan D., Boyko A., Vasilkova A., Vezhnovets T., Zvinchuk O., Latipov A., Myronyuk I., et al. (2019) Kadrovi resursy systemy okhorony zdorovia v Ukraini. Sytuatsiinyi analiz [Human resources of the health care system in Ukraine. Situational Analysis] Kiev: USAID Healthcare Support Project [in Ukrainian]

18. Vymohy PMH 2020. [PMG 2020 requirements] Natsionalna sluzhba zdorovia Ukrainy. Retrieved from: https://nszu.gov.ua/likar-2020 [in Ukrainian] (accessed 12 November 2019)

19. Vymohy PMH 2020. [PMG 2020 requirements] Natsionalna sluzhba zdorovia Ukrainy. Retrieved from: https://nszu.gov.ua/likar-2020 [in Ukrainian] (accessed 12 November 2019)

\section{Information about the author:} Myronyuk I. S., orcid.org/0000-0003-4203-4447

$\mathrm{PhD}$, Dean of the Faculty of Health and Physical Education Uzhhorod National University 3, Narodna Sq., 88000, Uzhhorod, Ukraine 


\title{
ORGANIZATIONAL MODEL OF A MULTIDISCIPLINARY APPROACH AT THE STAGE OF THE ESTABLISHMENT OF A NEW REHABILITATION SYSTEM IN UKRAINE
}

\author{
Spivak A. P.
}

\section{INTRODUCTION}

In the context of the ongoing reform of the health care system in Ukraine $^{1}$, the component of rehabilitation assistance has remained sidelined for a long time. The expert environment has long been drawing attention to the need to completely reboot the system of providing rehabilitation assistance to the population of the country ${ }^{2}$. Yes, the legal security is not in line with the international commitments made by Ukraine, namely the Convention on the Rights of Persons with Disabilities, which entered into force for Ukraine in March 2010 ${ }^{3}$. The World Health Organization (WHO) mission in 2015 also points to the inconsistency of the rehabilitation system of Ukraine with international standards ${ }^{4}$. A major impetus for the implementation of changes in the system of providing rehabilitation assistance to the population was the armed conflict in the east of Ukraine. The Law of Ukraine, which regulated the entire existing system of providing rehabilitation assistance in the country (the Law of Ukraine «On Rehabilitation of Persons with Disabilities in Ukraine»), in the 2005 version, extended exclusively to persons with disabilities, which, after the start of hostilities in 2014, became a significant obstacle for obtaining rehabilitation

1 Закон України «Про державні фінансові гарантії медичного обслуговування населення»//Відомості Верховної Ради (ВВР), 2018, № 5, ст.31. [Електронний ресурс] Режим доступу: https://zakon5.rada.gov.ua/laws/show/2168-19

2 Богдан Мойса. Пропозиції до політики щодо реабілітації осіб з порушеннями здоров'я. Policy paper. /Богдан Мойса. - Лабораторія законодавчих ініціатив, вересень 2017 [Електронний ресурс] - Режимдоступу: http://parlament.org.ua/wp-content/uploads/ 2017/09/Propozicii_Politiki_reabilitacii_zdoroviya-1.pdf

${ }^{3}$ Конвенція про права осіб з інвалідністю (Конвенція про права інвалідів): Верховна рада України. [Електронний ресурс] - Режим доступу: https://zakon.rada.gov.ua/laws/ show/z0417-19

${ }^{4}$ Оцінка системи реабілітації в Україні. Основні висновки. - Оціночна місія ВООЗ. Грудень 2015. - [Електронний ресурс]. - Режим доступу: http://www.physrehab.org.ua/ tl_files/Docs/Assessment $\% 20$ of\%20the\%20Rehabilitation\%20System\%20in\%20Ukraine.\%20S ummary\%20rstr\%20UKR.pdf 
services for persons whose status of disability ${ }^{5}$ has not been established. This version of the Act did not take into account the need for the provision of rehabilitation services to persons immediately after the acquisition of a health disorder. In 2014, the Act was amended, in particular, by categories of persons who may need rehabilitation services as a result of an anti-terrorist operation. With some modifications, the Act extends to 16 additional categories, mainly servicemen and employees of enterprises and institutions that have defended the independence, sovereignty and territorial integrity of Ukraine and participated directly in the Anti-Terrorist Operation.

Taking into consideration the need for changes in the regulatory regulation of the rehabilitation assistance system in the country, which would give impetus to the creation of conditions for the functioning of a modern effective system of medical, physical, psychological and other components of rehabilitation in the country legislators have begun to initiate changes to this law. Thus, in 2016, a draft law was submitted by a parliamentary group to regulate the activity of the rehabilitation assistance system - Draft Law of Ukraine of April 15, 2016 No. 4458 "On Disability Prevention and Rehabilitation System in Ukraine" ${ }^{6}$. In the Article 1 of this draw law «Definition of terms», in particular, for the first time it is proposed to regulate in Ukraine the concept of «multidisciplinary team» - a group of specialists of different specialties who provide rehabilitation services to a person in order to ensure the restoration or compensation of existing limitations of life. In 2017, another draft Law of Ukraine "On the Rehabilitation System in Ukraine" Ukraine. Although in this draft legislative act a separate definition the term «multidisciplinary team» has not been given, the term is used in the definitions of other terms used in the draft law. Thus in Article 1 "Definition of terms" of this act the following definition of the concept rehabilitation process is given - a set of rehabilitation measures consistently carried out by a multidisciplinary team and / or specialists of rehabilitation who provide help by themselves, in order to achieve and maintain an optimal level by a person in need of rehabilitation in interaction with the environment."

5 Закон України «Про реабілітацію інвалідів в Україні» // Відомості Верховної Ради України (BBP), 2006, N2-3, ст. 36. [Електронний ресурс] - Режим доступу: http://zakon.rada.gov.ua/laws/show/2961-15

${ }^{6}$ Проект Закону України від 15.04.2016 № 4458 «Про попередження інвалідності та систему реабілітації в Україні» [Електронний ресурс] - Режим доступу: http://search.ligazakon.ua/__doc2.nsf/link1/JH3FU00A.html

7 Проект Закону України "Про систему реабілітації в Україні" [Електронний pecypc] - Режим доступу: https://novynarnia.com/2017/10/02/zakon-ukrayini-pro-sistemureabilitatsiyi-v-ukrayini-proekt/ 
Therefore, the legislator proposes two variants of the subject of the rehabilitation process understanding: a multidisciplinary team and / or individual independent specialists in the field of rehabilitation.

\section{The optimal model of a multidisciplinary approach to rehabilitation care: complete implementation of the world experience}

The organization of comprehensive rehabilitation care for different groups of patients on the basis of a multidisciplinary approach is quite common in the world ${ }^{8}$. Models of the interdisciplinary organization of social and social services were widely considered in the field of social medicine and public health ten years ago. However, in practice, an interdisciplinary approach, unlike a multidisciplinary one, has not become widespread.

In the definitions of both interdisciplinary and multidisciplinary system of organization of provision of different types of services following general features can be distinguished:

- collaboration, teamwork of a team of specialists from different fields;

- interaction, communication;

- collegial development of common approaches, equal consideration of the opinions of all specialists;

- An interactive process that involves client participation, a strict focus on the client's individual needs.

Specialists who are part of an interdisciplinary team must have the skills to identify priority tasks, collect and share information, develop and evaluate decisions, develop common positions, implement solutions and evaluate results.

At the same time, there is one significant difference between a multidisciplinary and a multidisciplinary approach. In particular, in 1995, Finset A., Krogstad JM., Hansen H. and co-authors described the main differences in organizational models of interdisciplinary and multidisciplinary teamwork ${ }^{9}$. Thus, the "coordinated interdisciplinary teams» set common goals and specialists in each specialty try to work to achieve these goals in their individual sessions. At the same time, in the «integrated multidisciplinary teams» common goals are realized in joint rehabilitation sessions with the participation of specialists of different specialties participating in such sessions.

\footnotetext{
${ }^{8}$ Driller L. Fostering the interdisciplinary team, fostering research in a society in transition. Arch Phys Med Rehabil 1990; 71: 275-278.

${ }^{9}$ Finset A., Krogstad JM., Hansen H, et al. Team development and memory training in traumatic brain injury rehabilitation: to birds in a stone. Brain Injury 1995; 9: 495-507.
} 
The understanding of the concept of «rehabilitation» in the field of health care as most of disciplinary phenomena was formed gradually. Thus, even in the current wording of some legislative acts of Ukraine the separate concept of «medical rehabilitation» as a type of medical care is considered. Thus, the Fundamental Legislation of Ukraine on Health Care states that medical rehabilitation is a type of medical care provided to patients in an outpatient or inpatient setting, and includes a system of medical and other measures aimed at restoring impaired or lost functions of the body, to identify and activate the body's compensatory capabilities in order to create conditions for the person to return to normal functioning and preventing complications and relapses of the disease ${ }^{10}$. The legislative acts of Ukraine, which have not been adopted yet ("On Disability Prevention and Rehabilitation System in Ukraine" and "On Rehabilitation System in Ukraine"), define already different components of the rehabilitation system: medical, psychological, professional rehabilitation, physical therapy and others.

At the same time, WHO generally considers the concept of rehabilitation as broad as possible, without identifying its individual components ${ }^{11}$. So, from the point of view of WHO, rehabilitation is a set of measures that is necessary in cases where a person encounters or may encounter functional limitations in daily activities due to aging or health problems, including chronic illness or disorder, physical or mental injury. Therefore, the monodisciplinary approach to rehabilitation as a purely medical aid is considered outdated nowadays.

The active discussion of the implementation of multidisciplinary rehabilitation teams in the professional environment in Ukraine began after the signing of the order of May 25, 2018 under No. 981 on approval of the translation of the International Classification of Functioning, Life and Health Limitations of health among children and adolescents. This is implemented as part of the implementation of the Plan of Measures for the Provision of the International Classification of Functioning, Restriction of Life activity and health and the International Classification of Functioning, Limitation of Life and Health of Children and Adolescents, approved by Cabinet of Ministers Decree No. 1008 of December 28, 2017.

The International Classification of Functioning (ICF) was approved by all 191 members of the World Health Organization on May 22, 2001, during

\footnotetext{
10 Закон України «Основи законодавства України про охорону здоров'я» // Відомості Верховної Ради України (ВВР), 1993, № 4, ст.19. [Електронний ресурс] - Режим доступу: https://zakon.rada.gov.ua/laws/show/2801-12/ed20150101/find?text=\%CC\%E $5 \% \mathrm{E} 4 \% \mathrm{E} 8 \% \mathrm{~F} 7 \% \mathrm{E}$ D\%E0+\%F0\%E5\%E0\%E1\%B3\%EB\%B3\%F2\%E0\%F6\%B3\%FF

11 Реабилитация. Основные факты // Глоюальный веб-сайт ВОЗ. [Електронний peсурс] - Режим доступу: https://www.who.int/ru/news-room/fact-sheets/detail/rehabilitation
} 
the 54th World Health Assembly. ICF supplements another WHO classification, the 10th International Classification of Diseases (ICC).

ICF is a classifier used in all developed countries by doctors, educators, rehabilitation specialists and psychologists. Its use in Ukraine is the basis for developing a system of rehabilitation, early intervention and inclusion, for planning social protection measures, compensation systems and for developing and implementing their policies. It is the early intervention programs that are being actively implemented in Ukraine that have become the locomotive for the active introduction of multidisciplinary teams in all areas of rehabilitation assistance to the population.

Summarizing the experiences of the various sectors where multidisciplinary approaches are implemented (early intervention programs, hospice care and palliative care, etc.), the following approaches can be identified to form a multidisciplinary rehabilitation team. The multidisciplinary model of work is defined as a set of independent experts in different fields of knowledge with separate plans of action and separate functional tasks. They all work side-by-side, and even when practically separate from one another, the components of a patient's individual rehabilitation program are regularly coordinated at periodic team meetings. The internal relationships of independent team experts are coordinated by one team leader. The functions of the leader of this group include general leadership, the distribution of responsibilities of its members and the definition of the range of services that will be offered to each patient and his immediate environment. In the health care system of Ukraine, the role of the head of the multidisciplinary rehabilitation team is assigned to the doctor of physical and rehabilitation medicine by the Ministry of Health ${ }^{12}$. So, in particular, thedoctor of physical and rehabilitation medicine organizes team interaction between the specialists involved in the rehabilitation, with regular meetings.

The basic principles of teamwork are:

1) the principle of membership (you can be a member of the team, regardless of whether this activity is the main activity or not;

2 ) the principle of integration (expressed in the presence in the team of specialists of different specialties, whose knowledge and experience should help to achieve the chosen goal);

3 ) the principle of collective responsibility (reduced to the professional and legal responsibility of each team member for their own and collective

12 Про внесення змін до Довідника кваліфікаційних характеристик професій працівників. Випуск 78 «Охорона здоров’я»: наказ МОЗ України від 13.12.2018 № 2331. [Електронний ресурс] - Режим доступу: https://zakon.rada.gov.ua/rada/show/v2331282-18 
decisions, for using the collective resources that will be most effective for providing certain services).

A significant factor for the development of effective teamwork is the assessment of the work and capabilities of the rehabilitation team. To maintain the required level of success you must:

1. Members of the rehabilitation team form their own approach to measuring the quality of work.

2. The team has defined standards and procedures.

3 . The processes and results are regularly evaluated.

4. There is a system of improvement.

Equally important for the successful work of the team are the following personal and professional qualities: the ability to listen and make contact, openness, sincerity, honesty, the ability to clearly present their thoughts, the willingness to provide feedback on the results of their activities, stress resistance, the ability to go for personal and professional risk, a willingness to share experience and knowledge.

Ideally, a multidisciplinary rehabilitation team should include:

- doctor of Physical and Rehabilitation Medicine,

- physical therapist,

- ergotherapist,

- logotherapist,

- social worker,

- psychologist,

- prosthetist orthosis,

- rehabilitation Nurse.

The organizational model of a multidisciplinary rehabilitation team is shown in Figure 1.

An important aspect of the functioning of a multidisciplinary team is their territorial and, consequently, information unity. Such multidisciplinary teams are formed in powerful, mostly multidisciplinary rehabilitation centers, where the maintenance of permanent multidisciplinary teams are not only appropriate in terms of medical and social effectiveness, but also costeffective.

In the vast majority of cases, a multidisciplinary rehabilitation team does not require such a wide range of specialists and can function effectively in an optimized structure. The professional and quantitative composition of the team, as well as the level of training of its participants depends on certain factors, such as:

- the goals and objectives set by the medical or rehabilitation institution or those solved within the framework of a certain plan of activity; 
- the capacity of the medical rehabilitation institution or the opportunities of the territorial community;

- specialization and the list of types of medical and rehabilitation services provided by the institution;

- all the identified and documented needs of patients in rehabilitation services.

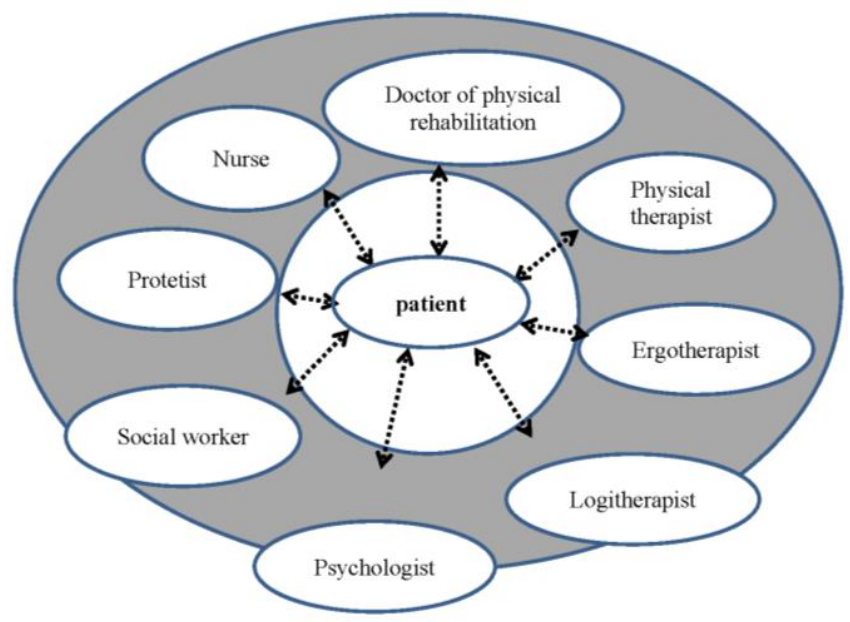

Fig. 1. The organizational model of a multidisciplinary rehabilitation team in ideal conditions

$\longleftrightarrow \cdots$ Direction of functional interection;

A single information field

The last statement in this list is the basic one, as a multidisciplinary approach to providing rehabilitation services is always client-centered. The client-centered approach requires that the patient is always at the center of the rehabilitation process or any therapy ${ }^{13}$. The main points of the clientcentered approach can be summarized as follows:

1. The client (the patient) seeks recovery. The role of the therapist (member of the rehabilitation team) is to use the desire of the client and guide him along the necessary path.

2. Therapy focuses on emotional aspects rather than intellectual aspects;

${ }^{13}$ Hart J. The development of client-centered therapy / J. Hart, T. Tomlinson // New Develop-ments in Client-Centered Therapy / J. Hart, T. Tomlinson. - Boston: HoughtonMifflin, 1970. - P. 3-22. 
3. Therapy is based on a specific situation (here and now) rather than past experience.

4. Therapy focuses on the client's initiative and helps solve their problem with a minimum of participation from the therapist.

The main therapeutic basis in the patient-centered approach is the relationship between the client and the therapist - a member of the rehabilitation team. The therapist practically creates an unconditionally positive environment (conditions) in which the resources for client changes are manifested.

Conditions include:

1. Acceptance - unconditional perception and respect towards the client, unconditional support and attention, care.

2. Empathy is an emotional orientation to the client and his empathic understanding. Empathy is a process in which the therapist becomes closer and closer to the client's inner world.

3. Therapist's congruence - the therapist is in agreement with his or her experiences. He is open to his own self-perception and ready to share with the client his experiences.

In case, all the identified needs of the patient in rehabilitation care can be met by the less extensive professional staff of a multidisciplinary team, it makes no sense to expand it. This statement is also true in cases of narrow specialization of rehabilitation centers, for example for patients with particular neurological or vascular diseases ${ }^{14}$. The optimal professional composition of a multidisciplinary team can be justified at different stages of patient rehabilitation ${ }^{15}$.

\section{Organizational model of a multidisciplinary approach to rehabilitation care at the transitional stage}

The rehabilitation assistance system in Ukraine is currently in its infancy. Central executive authorities, in particular the Cabinet of Ministers of Ukraine (CMU), the Ministry of Health (MOH) of Ukraine, have developed and issued a number of normative and regulatory documents that create the basis for the functioning of the rehabilitation assistance system in the new environment. Today, the process of normative regulation of human resources for the functioning of the rehabilitation assistance system as a component of

\footnotetext{
${ }^{14}$ Демиденко Т.Д., Ермакова Н.Г. Основы реабилитации неврологических больных. СПб.: Фолиант, 2004. - 304 с.

15 Малешко Г.В., Миронюк І.С., Слабкий Г.О., Брич В.В. (2019) Функціональноорганізаційні моделі реабілітаційної допомоги особам, що перенесли мозковий інсульт на регіональному рівні. Україна. Здоров’я нації. №2 (55). С. 87 - 96.
} 
the updated public health system is almost completed. In particular, the Ministry of Health of Ukraine formalized new specialties (professions) for health care workers: the professions of a physician, physical therapist, ergotherapist and assistants of physical therapist and ergotherapist ${ }^{16}$ were introduced. The issue of the possibility of introducing the positions of the mentioned above specialists in the health care institutions of Ukraine by amending the relevant regulatory order of the Ministry of Health of Ukraine of October 28, 2002 No. $385^{17}$ has been determined. Today, health care managers of all forms of ownership and of all levels of medical care can enter the positions of both FRM doctors, medical professionals (physical therapists, ergotherapists) and specialists (assistants of physical therapists and ergotherapists). Considering the peculiarities of the training of specialists in physical therapy issues, which have existed in Ukraine until recent years, the Ministry of Health of Ukraine issued a separate item in the order No. $668^{18}$ of 25.03.2019, authorizing the employment of the positions of physical therapists, ergotherapists and their assistants, masters «Physical Rehabilitation» and the direction of preparation «Health of a person» in the field of knowledge» Physical Culture and Sports». This was an important decision, because specialty 227 «Physical therapy. Ergotherapy "in the field of knowledge 22. Healthcare formally appeared in Ukraine only in 2017 and, accordingly, the training of specialists in this new specialty in higher education institutions began only in September 2017. Based on the above mentioned facts, the first bachelors in the specialty «Physical therapy, Ergotherapy" will only serve as physical therapists and ergotherapists in the summer of 2021. The saturation of the labor market in the field of rehabilitation assistance for physical therapists, ergotherapists and doctors of the FRG has already begun (the period of study in the magistracy for medical professionals and for specialization for doctors does not exceed 1.5 years). But the first graduation of such specialists, of course, will not meet the needs of the labor market in this field.

It should also be mentioned that a full-fledged labor market for both future graduates of higher education institutions in these specialties and for already trained specialists in Ukraine has not been formed yet. It is true that rehabilitation and spa facilities provide remote stages of rehabilitation care

16 Про внесення змін до Довідника кваліфікаційних характеристик професій працівників. Випуск 78 «Охорона здоров’я»: наказ МОЗ України від 13.12.2018 № 2331. [Електронний ресурс] - Режим доступу: https://zakon.rada.gov.ua/rada/show/v2331282-18

${ }^{17}$ Про внесення змін до наказу Міністерства охорони здоров'я України від 28 жовтня 2002 року № 385: наказ МО3 України від 25.03.2019 № 668. [Електронний ресурс] Режим доступу: https://zakon.rada.gov.ua/laws/show/z0417-19

${ }^{18}$ Так само 
have gradually begun to enter the posts of appropriate specialists, on the other hand health care providers that provide emergency and planned medical care are in no hurry to do so. At present, the existence of a post of physical therapist or / and ergotherapist in public institutions (communal medical non-profit enterprises) of secondary (specialized) and tertiary (highly specialized) levels of providing medical care to the population is rather an exception than a rule. At the primary and territorial communities level, this phenomenon is not observed at all. The current situation is largely influenced by the process of rapid reform of the system of medical assistance to the population of Ukraine, which has directly affected secondary and tertiary level healthcare institutions. In the context of systemic changes, the heads of such institutions are in no hurry to make significant changes to staffing lists and directions of providing medical services to the population.

Special mention should be made of the provision of healthcare facilities and such potential members of multidisciplinary teams as psychologists, social workers and logotherapists. These professionals are representatives of other fields, and are those who rarely included in the staffing of healthcare institutions. There are cases when some types of positions of social workers and / or psychologists are involved into the staffing list of specialized healthcare institutions for full-time These are usually drug dispensaries, phthisiatric care facilities, AIDS Centers and oncology hospitals (dispensaries). The specialty of "Logotherapist" in the field of knowledge 22 does not currently exist in health care system of Ukraine. It is also possible to involve rehabilitation teams of specialists of pedagogical profile - speech therapists in the work of multidisciplinary teams.

Considering current situation in the staffing of healthcare facilities by potential members of multidisciplinary rehabilitation teams, there is an urgent need to develop temporary organizational models of a multidisciplinary approach to rehabilitation care at a transitional stage. In each case, such an organizational model must be adapted to the available human and material resources of the healthcare facility.

Of course, today, some specialized rehabilitation centers of both state (communal) and private ownership have sufficient staff to form optimal multidisciplinary rehabilitation teams. If necessary, in some cases, they involve teamwork and external experts. Such a model of forming multidisciplinary rehabilitation teams is more probable and is implemented in large cities where the shortage of specialists in particular specialties is not critical. In the case of small towns and cities, multi-disciplinary healthcare institutions, the formation of the optimal team is difficult. 
The organizational model of a multidisciplinary rehabilitation team for the transition stage of the establishment of a rehabilitation system at the level of a healthcare facility is shown in Figure 2.

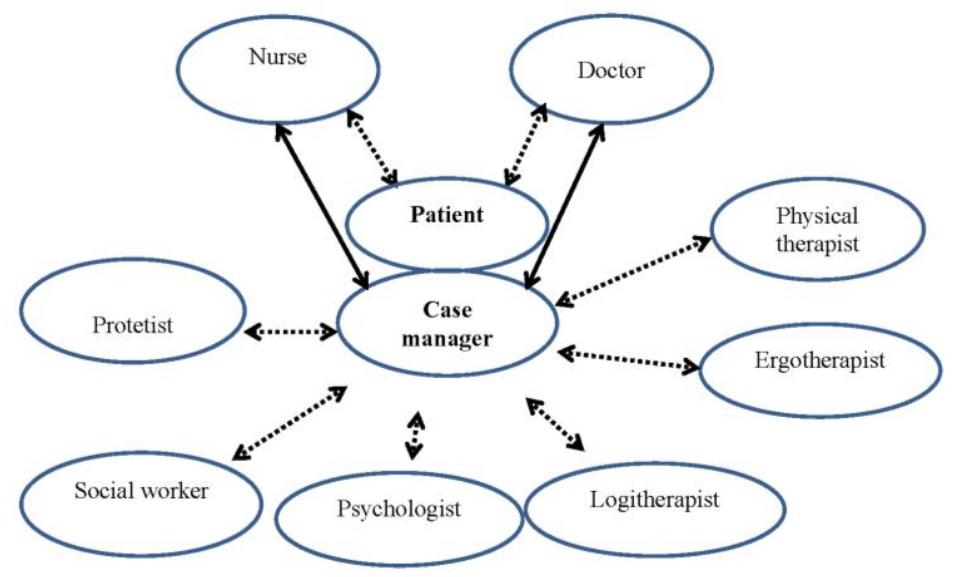

Fig. 2. Organizational model of a multidisciplinary rehabilitation team in transitional period $\longleftrightarrow \cdots$ Direction of functional interaction $\longleftrightarrow$ Direction of information interaction

In transitional conditions, there is a need to introduce into the multidisciplinary rehabilitation team an additional structural element - a member of the multidisciplinary team, who provides coordination of the patient's treatment - case manager. The key functions of the case manager are coordination and communication. In fact, the case manager directly interacts with the patient and members multidisciplinary teams that are staff members of the healthcare facility and permanent members of the multidisciplinary team. In the presented model the minimum possible composition of such a multidisciplinary team based on a single healthcare facility is shown: physician (if available - FRM physician), nurse and case manager. With the establishment of a health care facility in the state, staff members who may be involved in the work of a multidisciplinary rehabilitation team may be expanded to include a permanent staff member. Other necessary specialists are involved in team work according to the needs of the patient and as a the appointment of team leader (physician) case manager. 
The functions of the case manager can be assigned to a full-time employee of a health care facility, and a member of the rehabilitation team to a nurse. At the same time, external experts can be involved in performing these functions: representatives of non-governmental or charitable organizations, volunteers, members of the patient's immediate environment. Considering that any multidisciplinary team is formed mostly due to the situation, it is important to understand that the formation of its composition should be based on the patient-centered principle mentioned above. It is the identified and documented needs of a particular patient in rehabilitation services that are basic to forming a multidisciplinary rehabilitation team and the stage of involvement of individual members in the work.

This approach is realistic for the vast majority of health care facilities in a shortage of human and material resources and is economically eviable. In its implementation, individual members of the multidisciplinary rehabilitation team are involved occasionally, if there is a justified need, or act as external consultants, enabling economical use of resources.

Assigning case manager as a permanent member of a multidisciplinary rehabilitation team to a full-time employee healthcare provider (nurse, social worker, or other) will give the facility manager significant benefits over the temporary performance of these functions by different facility employees. An employee who constantly performs the functions of case manager in multidisciplinary rehabilitation teams with time will obtain necessary experience and special knowledge, improve his skills and will be able to do additional functions, for example, to coordinate the stage of providing rehabilitation assistance in the conditions of a single medical area and rehabilitation.

\section{CONCLUSION}

The rehabilitation assistance system in Ukraine is undergoing a complete systemic reboot and refinement phase to adapt to international standards. One of the basic approaches for providing rehabilitation care to patients is a multidisciplinary approach, which is functionally implemented by multidisciplinary rehabilitation teams of different specialists. The world experience of functioning of such multidisciplinary rehabilitation teams showed their effectiveness, worked out the optimal composition and forms of work organization. Implementation of the international experience of multidisciplinary rehabilitation teams in Ukraine at the current stage of the industry development is limited, in some powerful specialized rehabilitation centers in large cities. At the same time, in most areas of the country, health care institutions do not currently have the human or material resources to 
implement optimal models of a multidisciplinary rehabilitation approach and to form teams. The suggested organizational model of a multidisciplinary rehabilitation team for the transition phase of establishing a rehabilitation system at the level of a health care facility can be implemented in almost any health care facility in Ukraine and adapted to the specific conditions of operation of this institution. Introduction of multidisciplinary rehabilitation functionally team of a new member of the team - case manager, will allow effective use of personnel, logistical and financial resources of the health care institution with providing the optimal level of rehabilitation care for the patients of the institution. This model can be easily adapted to changes in the staffing of both the healthcare facility itself and the changes in the market of medical and rehabilitation services within the territory of the institution. As the labor market recharges the health care system, the proposed transition model will evolve to the best accepted model.

\section{SUMMARY}

The results of descriptive modeling of organizational and structural support for the functioning of rehabilitation assistance to the population of Ukraine on the basis of a multidisciplinary approach in the transition period are presented in the paper. An organizational model of a multidisciplinary rehabilitation team is suggested for the transitional stage of the establishment of a rehabilitation assistance system at the level of a health care institution, which can be implemented in almost any health care institution of Ukraine and adapted to the specific functioning of this institution. The subject of the study was the practical system of rehabilitation assistance in the country at the present stage of its development and the state of its readiness to work in new conditions. The innovation of introducing functionally into the multidisciplinary rehabilitation team of a new team member - case manager, will allow efficient use of personnel, material, technical and financial resources of the health care institution with providing the optimal level of rehabilitation care for patients of the institution. This model easily adapts to changes in the staffing of both the healthcare facility itself and the changes in the market of medical and rehabilitation services within the territory of the institution.

\section{REFERENCES}

1. Pro derzhavni finansovi harantii medychnoho obsluhovuvannia naselennia [On State Financial Guarantees of Medical Services to the Population] (2018): Zakon Ukrainy [Law of Ukraine]. Retrieved from: 
https://zakon5.rada.gov.ua/laws/show/2168-19 [in Ukrainian] (accessed 10 November 2019)

2. Bohdan Moysa (2017) Propozytsii do polityky shchodo reabilitatsii osib z porushenniamy zdorovia. Policy paper. [Proposals for a policy on the rehabilitation of persons with disabilities. Policy paper] Laboratoriya zakonodavchykh initsiatyv. Retrieved from: http://parlament.org.ua/wpcontent/uploads/2017/09/Propozicii_Politiki_reabilitacii_zdoroviya-1.pdf [in Ukrainian] (accessed 10 November 2019)

3. Konventsiia pro prava osib $\mathrm{z}$ invalidnistiu (Konventsiia pro prava invalidiv) [Convention on the Rights of Persons with Disabilities (Convention on the Rights of the disabled)] (2010). Retrieved from: https://zakon.rada.gov.ua/laws/show/995_g71 [in Ukrainian] (accessed 10 November 2019)

4. Otsinka systemy reabilitatsii v Ukraini. Osnovni vysnovky [Assessment of the rehabilitation system in Ukraine. The main conclusions] (December 2015). WHO evaluation mission. Retrieved from: https://physrehab.org.ua/wp-

content/uploads/docs/Assessment\%20of\%20the\%20Rehabilitation\%20Syste m\%20in\%20Ukraine.\%20Summary\%20rstr\%20UKR.pdf_[in Ukrainian] (accessed 11 November 2019)

5. Pro reabilitatsiiu invalidiv v Ukraini [On Rehabilitation of Persons with Disabilities in Ukraine] (2006): Zakon Ukrainy [Law of Ukraine] Retrieved from: http://zakon.rada.gov.ua/laws/show/2961-15 [in Ukrainian] (accessed 11 November 2019)

6. Pro poperedzhennia invalidnosti ta systemu reabilitatsii v Ukraini [On Disability Prevention and Rehabilitation System in Ukraine] ( 2016, April 15): Proekt Zakonu Ukrainy [Draft Law of Ukraine] No. 4458. Retrieved from: http://search.ligazakon.ua/__doc2.nsf/link1/JH3FU00A.html [in Ukrainian] (accessed 11 November 2019)

7. Pro systemu reabilitatsii v Ukraini [On the Rehabilitation System in Ukraine]: Proekt Zakonu Ukrainy [Draft Law of Ukraine]. Retrieved from: https://novynarnia.com/2017/10/02/zakon-ukrayini-pro-sistemureabilitatsiyi-v-ukrayini-proekt/ [in Ukrainian] (accessed 11 November 2019)

8. Driller L. Fostering the interdisciplinary team, fostering research in a society in transition. Arch Phys Med Rehabil 1990; 71: 275-278. 
9. Finset A., Krogstad JM., Hansen H, et al. Team development and memory training in traumatic brain injury rehabilitation: to birds in a stone. Brain Injury 1995; 9: 495-507.

10. Osnovy zakonodavstva Ukrainy pro okhoronu zdorovia [Fundamentals of Ukrainian legislation on health care] (1993): Zakon Ukrainy [Law of Ukraine]. Retrieved from: https://zakon.rada.gov.ua/ laws/show/2801-12/ed20150101/find?text=\%CC\%E5\%E4\%E8\%

$\mathrm{F} 7 \% \mathrm{ED} \% \mathrm{E} 0+\% \mathrm{~F} 0 \% \mathrm{E} 5 \% \mathrm{E} 0 \% \mathrm{E} 1 \% \mathrm{~B} 3 \% \mathrm{~EB} \% \mathrm{~B} 3 \% \mathrm{~F} 2 \% \mathrm{E} 0 \% \mathrm{~F} 6 \% \mathrm{~B} 3 \% \mathrm{FF}$ [in Ukrainian] (accessed 11 November 2019)

11. Reabilitatsiya. Osnovnyie faktyi [Rehabilitation. Basic facts]: Globalnyiy veb-sayt VOZ. Retrieved from: https://www.who.int/ru/newsroom/fact-sheets/detail/rehabilitation [in Russia] (accessed 11 November 2019)

12. Pro vnesennia zmin do Dovidnyka kvalifikatsiinykh kharakterystyk profesii pratsivnykiv. Vypusk 78 «Okhorona zdorovia» 78 [Changes to the Handbook of qualification characteristics of professions of workers «Health care order»] (2018, December 13): nakaz Ministerstva okhorony zdorovia Ukrainy [order of the Ministry of Health of Ukraine] № 2331. Retrieved from: https://zakon.rada.gov.ua/rada/show/v2331282-18 [in Ukrainian] (accessed 11 November 2019)

13. Hart J., T. Tomlinson (1970) The development of client-centered therapy. Boston: Houghton-Mifflin, pp. 3-22.

14. Demydenko T.D., Ermakova N.H. (2010) Osnovyi reabilitatsii nevrologicheskih bolnyih [Basics of Neurological Rehabilitation] Moscow: Folyant. ( in Russian)

15. Maleshko H.V., Myronyuk I.S., Slabkyy H.O., Brych V.V. (2019) Funktsional'no-orhanizatsiyni modeli reabilitatsiynoyi dopomohy osobam, shcho perenesly mozkovyy insul't na rehional'nomu rivni.[ Functionalorganizational models of rehabilitation assistance to people who suffered a stroke at the regional level. ]. Ukraine. The nation's health. Vol. 2, no. 55, pp. $87-96$.

16. Pro vnesennia zmin do Dovidnyka kvalifikatsiinykh kharakterystyk profesii pratsivnykiv. Vypusk 78 «Okhorona zdorovia» 78 [Changes to the Handbook of qualification characteristics of professions of workers «Health care order»] (2018, December 13): nakaz Ministerstva okhorony zdorovia Ukrainy [order of the Ministry of Health of Ukraine] № 2331. Retrieved 
from: https://zakon.rada.gov.ua/rada/show/v2331282-18 [in Ukrainian] (accessed 11 November 2019)

17. Pro vnesennia zmin do nakazu Ministerstva okhorony zdorovia Ukrainy vid 28 zhovtnia 2002 roku № 385 [On amendments to the order of the Ministry of Health of Ukraine № 385 ( 2002, October 28)] : nakaz Ministerstva okhorony zdorovia Ukrainy [order of the Ministry of Health of Ukraine] № 668. (2019, March 25). Retrieved from: https://zakon.rada.gov.ua/laws/show/z0417-19 [in Ukrainian] (accessed 11 November 2019)

Information about the author: Spivak A. P. orcid.org/0000-0001-7070-3746

Physical Rehabilitologist, Seniour Lecturer of the Department Of Physical Education

Uzhhorod National University 3, Narodna Square, 88000, Uzhhorod, Ukraine 


\section{EVOLUTIONAL CHANGES IN MODERN THINKING IN MEDICAL STUDENTS AND THEIR INTEGRATION IN HIGHER MEDICAL EDUCATION}

\section{Barannik K. S.}

\section{INTRODUCTION}

It is known that the increasing role of information, information technology has led to the fact that modern society exists at a new stage of development - information. There is a fundamentally new way of communicating and broadcasting information, dubbed «screen culture.» In fact, a new habitat for human beings is being formed - an information society, the specificity of which is the transmission of information by means of a moving image supplemented by sounds. The impact of the information society touches upon the spheres of people's society, their learning and governance processes. Under his influence there is a change of thinking, in connection with which more and more often in the scientific literature such concepts as «man-screen», «clip-thinking», «clip-consciousness» appear ${ }^{1}$. Due to the informatization of education, which is now considered almost a panacea, there are risks of the loss of the creative cultural and generational capacity of whole generations. If the older generation still retains other forms of perception of the information provided (comprehension, comparison, analysis, criticism, etc.), then the younger generation, and students in the first place, is increasingly dynamic, mosaic, «clip» receiving, processing and imaging information, first of all - educational. Clip thinking «as a phenomenon is a response to the growing amount of information. The media have developed a universal format for submitting information, the essence of which is to submit a set of abstracts or clips without defining context, because because of its relevance, the context for the thesis is objective reality. In other words, the universal media format forces events to be related if they have a temporary affinity rather than a factual one. The society, being at the present stage of development, is transformed into an «electronic society» or «global village» «And defines, through electronic

\footnotetext{
${ }^{1}$ Barannyk S.I., Yekhalov V.V., Romanyuta I.A., Lyashchenko P.V. (2018). Intehratsiya «klipovoho myslennya» v suchasnu vyshchu medychnu osvitu. Pivdennoukrayins'kyy medychnyy naukovy zhurnal. № 19(19) february. pp. 8-12.
} 
means of communication, a multidimensional perception of the world. The development of electronic means of communication returns human thinking to the pre-textual age, and the linear sequence of signs ceases to be the basis of culture. mainly visual and associative, archaic and devoid of temporal and spatial categories, and the individual has no need to remember information, summarize it, and make sense of it. He ceases to acquire objects of knowledge because they are illusory. This specificity of remembering the «electronic personality» entails a corresponding change in thinking reducing the number of desired, sought, meaningful, unknown objects. And the thought, which has lost its problematic components, ceases to generate thoughts, images, symbols, ideas ${ }^{2}$. Clip culture creates unique forms of perception, such as «zapping», «channel zapping», when switching channels of television continuously creates a new image consisting of fragments of information and excerpts. This image does not require connection of imagination, reflection, comprehension. All the time there is a «reboot», «updating» of information, when everything initially seen without a temporary break loses its meaning, that is, becomes obsolete. Modern people, accelerating the pace of change, forever broke with the past. The abandonment of the previous way of thinking, of the previous feelings, of the previously established methods of adaptation to those conditions of life that are constantly changing, contributes to the constant search for one's identity. The acceleration of the pace of life is no longer within the scope of normal human existence, under its pressure all social institutions of society are changing. It was under this continuous informational bombardment of human consciousness that the «clip thinking» was formed. Humanity captures such a psychological previously unknown condition, which in its impact can be equated with illness. This disease also has the name «futuroshok» - «shock of the future.»

Factors that influenced the formation of a new, diffused, defragmented type of thinking:

1. Acceleration of the pace of life and constant increase of information flow.

2. Increasing requirements for the speed of receipt of information and its relevance.

3. Increasing the diversity of incoming information.

4. Increase in the number of cases that a person deals with simultaneously.

${ }^{2}$ Hych H. M. (2016). «Klipove» myslennya molodi: druh chy voroh navchannya? Naukovi pratsi. Pedahohika, vipusk. 257. T. 269. p. 38-42. 
5. The growth of democracy at different levels of the social system: preaching becomes a debate, rhetoric - a dialectic ${ }^{3}$.

6 . The language of images and gestures is much older than the language of symbols, so it is easier for a person to perceive information in the form of images than in a linear form (letters, numbers, formulas, etc.).

In today's society, there has been a steady tendency to form fragmentary provision and to obtain information with a dominance of quantity rather than quality. In psychology, pedagogy and journalism, such thinking is characterized as a clip - fragmentary and illogical ${ }^{4}$. Today, we have to talk about the peculiarities and consequences of such thinking, including:

- inability to handle large amounts of data;

- simplifying information;

- large but haphazard awareness of any issues;

- «clip» is increasingly replacing the meaning of the story structure of the text (context);

- pursuit of external signs and change of impressions, the advantage is given to virtual reality: objective reality also becomes simulative;

- inhibition of the ability to concentrate on one thing for a long time;

- the possibility of being exposed to external influence and manipulation;

- limiting the ability to analyze and build long logical circuits;

- weakening of empathy (compassion), guilt and responsibility;

- permanent over-excitement, rapid fatigue, procrastination (constant postponement of difficult cases «for later»), mental lability.

Often, the complaints that young people read poorly and poorly understand the content of the reading can be heard from the mouth of teachers of different disciplines, the study of which is related to the processing of a large number of primary sources in the form of verbal texts. The same applies to traditional lectures, which suggest that the focus of the listeners over time is focused on one subject. Obviously, traditional teaching methods present serious difficulties for learners with a non-textual type of perception, the number of which is increasing rapidly every year. Experts from different industries who are paying attention to this problem are divided into two camps, which can be conditionally defined as

${ }^{3}$ Yekhalov V.V., Samoylenko A.V., Romanyuta I.A., Barannyk S.I. (2018). Klinichne ta «klipove» myslennya u likariv-interniv. Ukrayins'kyy zhurnal medytsyny, biolohiyi ta sportu. Tom 3, №1(10). pp. 241-244.

${ }^{4}$ Barannyk S.I., Yekhalov V.V., Mizyakina K.V., Barannik K.S. (2019). Evolyutsiyni aspekty «Klipovoho myslennya» u studentiv-medykiv ta yikh intehratsiya u vyshchu medychnu osvitu. «Sotsial'no-humanitarni doslidzhennya ta innovatsiyna osvitnya diyal'nist'» Materialy Mizhnarodnoyi naukovoyi konferentsiyi. 24-25 travnya 2019 r., m. Dnipro / Nauk. red. O.Yu. Vysots'kyy. Dnipro: SPD «Okhotnik». 528 P. pp 435-438. 
«conservative» and «progressive». Conservatives want to keep the perception and consciousness of people within anything within the cognitive style that seems to them to be more sophisticated. In order to prevent the emergence / progression of clip-on thinking, special trainings are offered to help focus more attention, and we recommend reading more classic texts.

Due to the informatization of education, which is now considered almost a panacea, there are risks of the loss of the creative cultural and generational capacity of whole generations. If the older generation still retains other forms of perception of the information provided (comprehension, comparison, analysis, criticism, etc.), then the younger generation, and students in the first place, are increasingly dynamic, mosaic, «clip» receiving, processing and imaging information, first of all - educational. A person cannot concentrate on information for a long time, and his / her ability to analyze is significantly reduced. It is difficult for the owner of the clip thinking to analyze the situation, since any information is not delayed in his mind and is quickly replaced by new 3 . The success rate decreases and the learning rate decreases. People quickly forget what they have been taught recently and cannot master the works of classical literature ${ }^{5}$. Clinical medicine today faces two dangers: fetishization of technology and neglect of clinical thinking, which give rise to such a negative phenomenon in the medical environment as «feldsherism» («action - result», without taking into account the individual features of the patient, pathogenesis, mechanisms of effects, mechanisms of action, mechanisms of action,

However, the future doctor should be guided by a large number of new drugs, follow the guidelines of clinical protocols and doctrines, and his activities should be based on the principles of evidence-based medicine. He needs to analyze dozens of metrics at once. All of these symbols should be the same as a single analytical picture. The quality of work of a future doctor depends on how quickly and well he analyzes the information and makes decisions in a difficult situation. Sometimes it only takes seconds. Logical thinking is a priority for those who have too much time, but sometimes too little. Our specialty cannot be learned only through textbooks. The doctor should be able to think. You can read a lot of books, protocols,

${ }^{5}$ Yekhalov V.V., Sedinkin V.A., Barannyk S.I. (2017). «Klipove myslennya» ta suchasna vyshcha medychna osvita. Aktual'ni pytannya osvity i nauky: zbirnyk naukovykh statey, materialy V mizhnarodnoyi naukovo-praktychnoyi konferentsiyi 10-11 lystopada 2017 r. / Natsional'na akademiya Natsional'noyi hvardiyi Ukrayiny. Kharkiv: KHOHOKZ. 384 p. pp 172-178. 
recommendations and face a complication that is not spelled out. The most responsible task of the doctor is to find a solution in non-standard situations ${ }^{6}$.

The contradiction that arises between the vast amount of information we need to process and the growth of our workload is forcing our future colleague to «protect himself to survive.» So why not «turn your enemy into a friend» using the positives of clip-thinking, which:

- allows you to see the multifaceted, multivariate, ambiguous approaches to the analysis or solving specific issues and problems;

- creates an opportunity to protect against excessive flow of information;

- promotes greater adaptation to and changing social reality.

Clip thinking is negative only when it is related to the inability to determine the main thing. And if such an opportunity is, then in our time it becomes a strength, not a weakness. The control function focuses on the dynamic distribution of the attention of the anesthesiologist between numerous problems, routine and non-routine actions. Resource management is at the highest level of mentality, which knows all the available reserves. These two levels imply a flexible adaptation of the thinking process. This ability to «analyze thinking» in order to strategically control one's own mentality, called psychologists' metacognition, is a very important contribution to the successful resolution of critical situations in medical practice.

The «clip» way of working with information adds dynamism to cognitive learning activities, which allows us to manage, at least formally, the necessary tasks in the conditions of a growing amount of educational material: often we get to the situation when we mention something, but we are not completely sure of the accuracy of reproduction information. Clip behavior allows you to see the multifaceted, multivariate, ambiguous approaches to analyzing or solving specific issues and tasks (this thinking helps the audience to better understand and understand the wide variety of relationships between phenomena and events). Clip thinking can be used as a protective reaction of the body to information overload, contributes to greater adaptation to the changing social reality and its cognition; If we take into account all the information that a person sees and hears in a day, plus the «world dump» the Internet, then it is not surprising that her thinking

\footnotetext{
${ }^{6}$ Kligunenko Ye.N., Yekhalov V.V., Kushch Ye.A., Kravets O.V., Gayduk O.I., Barannik S.I., Khobotova N.V.(2019)/ Klipovoye myshleniye v anesteziologii: katastrofa ili zakonomernost’? Meditsina nevídkladnikh staní. № 3(98). pp. 111-123.
} 
changes, adapts, adapts to new conditions ${ }^{7}$. However, the "clip culture" is a reaction to social dynamics and an information boom that helps one's selfpreservation and adaptation to the environment. Thus, we can say that with the help of «clip thinking» a person escapes from the flow of information that presses on him. In general, in modern science, clip thinking is mostly referred to in a negative sense, in the context of a transformation of consciousness characterized by degradation. Many talk about superficial, eclectic, stereotypical perception of information. There are also some positive points: first, it is a security feature that cuts off a huge amount of information that is becoming more and more available, allowing you to get results quickly, using certain data. In any case, the factors that have provoked the formation of clip thinking are known, such as electronic publishing and network media, the Internet, mobile devices, ie technologies that are the driving force behind progress, which is known to be irreversible. Clip culture is becoming an integral component of the anthropological type of human information society. All this requires a separate thorough study ${ }^{8}$. Clip thinking «is a new form of development of human relations with information that needs to be widely studied.

\section{The aim of the study}

In our work we tried to analyze the impact of "clip thinking" on the ability of medical students to learn practical material during higher education, and to determine its level in different groups of students.

\section{Material and methods.}

The material for the study were the results of an anonymous survey of 300 students of the third year of medical faculty and interns who had a fulltime study at the Dnepropetrovsk Medical Academy of the Ministry of Health of Ukraine during the 2016/17 academic year (group A - 100 people), interns (group B - 100 people) and Group B (100 students of III year students) of the 2018/19 academic year. The questionnaire was used for the survey $^{9,10}$, which contained a diverse plan of 30 questions with two answer

\footnotetext{
${ }^{7}$ Litvinova M.B. (2017). Dosvid diahnos/tuvannya klipovoho myslennya. Pedahohichni nauky Vypusk LXXVI, Tom 3. pp. 140-145

Semenovskikh T. V. Fenomen (2014) «klipovogo myshleniya» v obrazovatel'noy vuzovskoy srede. Internet-zhurnal «Naukovedeniye», vip. 5(24). pp. 1-10.

${ }^{9}$ Kligunenko Ye.N., Yekhalov V.V., Kushch Ye.A., Kravets O.V., Gayduk O.I., Barannik S.I., Khobotova N.V.(2019)/ Klipovoye myshleniye v anesteziologii: katastrofa ili zakonomernost'? Meditsina nevídkladnikh staní. №3(98). pp. 111-123.

${ }^{10}$ Litvinova M.B. (2017). Dosvid diahnostuvannya klipovoho myslennya. Pedahohichni nauky Vypusk LXXVI, Tom 3. pp. 140-145.
} 
options, one of which was correct in determining the propensity for «clip thinking». The processing of the obtained data, their comparison with the given literary data of other researchers and two groups of own research allowed not only to evaluate its level but also to determine the personality of the mental approach to the use of this type of thinking by persons of different research groups.

\section{Research results.}

The data obtained from the students of group A showed that the average of correct answers (14.36) was 14\% of the respondents, 53\% of persons did not reach it and 33\% - exceeded this indicator. Group B interns showed a lower average of correct answers (12.0). It was reached by $10.25 \%$ of respondents, but the number of persons who did not reach it or surpassed it was the same $-44.87 \%$. But if you set an assessment criterion of 15 correct answers, then among students of group A who exaggerated it was $33 \%$, and among interns of group B - 17 persons (17\%). As for the students of group $\mathrm{B}$, the average of correct answers was 14.1 and it was reached by $17 \%$ of respondents. $37 \%$ of respondents in this group did not reach it but $46 \%$ exceeded this leper. Comparing with the 15 correct answer criterion, $36 \%$ of students who outperformed it, which is also more than in groups A and B. This may indicate positive trends in the evolutionary ability of the «clipthinking» ability. in the following age groups of students.

Qualitative analysis of the specific answers to the questionnaire showed that students are more likely to receive information through visual demonstration material compared to interns, but it is difficult for them to separate rational information from general terms, which takes a lot of time when working with specialized literature. This can be explained by the fact that they are in a state of accumulation of basic training material in comparison with the doctors-interns, which more consolidate the previously obtained level of knowledge. Despite having a strong commitment to using the latest computer technology to obtain information (72\% vs. $49 \%$ with interns), most students enjoy reading books (95\% vs. $75 \%$ with interns) whose content they remember best (79\% against 66\%) and trying to record for later use ( $93 \%$ vs. $75 \%)$.

Students have a better understanding of the material they study with the teacher $(80 \%$ vs. $64 \%)$ than what they have to get online. But it should be noted that lack of experience compels students to pay more attention to a thorough study of the object instead of forming a general idea about it (66\% 
vs. 55\%). The general analysis showed that modern students and interns are free to navigate in the modern rhythm of life, make good use of modern sources of information.

Qualitative comparative analysis conducted among students of groups A and B, separated by 2 years of study in the third course, showed the following data. Group B students were more resistant to possible third-party obstacles to gaining certain educational information. However, they equally used educational information and did not require special conditions for its receipt. In achieving the goal, they were more successful in solving problems of extreme help and making the right decision. However, a minimal amount of information was used. To obtain the necessary information carefully analyzed receiving it from electronic media, the Internet. It was believed that successful development without an information system similar to our computers is possible, but this requires a sufficient level of training. Like the students of group A, they enjoyed reading professional literature, but emphasized the benefits of visual information (videos, computer training programs). They are attracted to the stable situation, and they are still trying to make the necessary notes in lecture notes, as opposed to information on the Internet. To form a general idea of a phenomenon or object, they believe that there are ways to get information quickly.

The obtained data coincide with the data of previous studies and publications. ${ }^{11}$ Yes, students' negative clipping is more pronounced: this is due to the fact that teachers require them to study primary sources, educational literature, summarize and analyze specific information. and when they do not, the search for interactive learning and impact methods begins; Secondly, with the global informatization of society over the last ten years, the pace of information exchange has been accelerated, giving the young man the confidence to quickly solve a difficult task for him: why go to the library to take and then read a monograph on the subject when it is enough to open Google, to find, download from the network first (which almost never meets modern requirements) information, or openly tell the teacher: «Why prepare at home if you still explain everything to us.» This is already shaping the consumer approach to learning. A generation of «quick

\footnotetext{
${ }^{11}$ Nesterova L.YU., Napalkov S.V. (2016). Razvitiye klipovogo myshleniya u studentov v sisteme vysshego obrazovaniya posredstvom opornykh graf-skhem. Vestnik Nizhegorodskogo universiteta im. N.I. Lobachevskogo. Seriya: Sotsial'nyye nauki. № 4 (44). pp. 207 - 215.
} 
buttons» wants educational information to be provided to them in their usual, «clip» form (presentations of lessons, brief notes, reference schemes, drawings, etc.). These requirements are insufficiently addressed by the authors of new educational programs and modern textbooks. A person cannot concentrate on information for a long time, and his / her ability to analyze is significantly reduced. It is difficult for the clip-thinking owner to analyze the situation, as any information is not delayed in his mind and quickly changes to new ones. The success rate decreases and the learning rate decreases. People quickly forget what they have recently been taught and cannot master classical works.

The question here is about the ability to analyze and establish cause and effect relationships with the ability to quickly process finding information to switch from one subject to another. The task of finding the perfect proportion between the given properties is hard to imagine. Assuming that in the modern world the value of knowledge is determined only by its use in practice, the only criterion for the evaluation of this proportion can be considered for what purposes this knowledge is acquired. Obviously, in the information environment in which the modern man lives, the ability to quickly switch and process information is essential. The real question here is - is not the attempt to return to traditional text-centric pedagogy an attempt to "pull" today's reality into an already dying system of education that does not answer it? What can traditional education counter the network? Social networks that continue to win the world are increasingly integrated into the educational process - special communities are created where all kinds of tutorials, lectures, videos and audio are created, students ask teachers to send assignments there, because this way is more convenient than even email.

In this regard, it seems more progressive not to combat the spread of a new type of thinking, but to try to gradually reorganize the educational process to meet new requirements, integrate innovative tools and methods, increase its involvement in it, distribute classes into blocks for better learning. material, switching from one activity to another. If the latter conditions are met, however, it is necessary to summarize at the end of the lesson, logically linking the mentioned blocks. The need to implement these methods is due to all the same types of perception common to young people - visual and kinesthetic. Many modern students approach higher education from a purely practical point, which is facilitated, among other things, by the integration of universities into the Bologna process, which 
involves the introduction of a modular rating system of assessments. Students pay less and less attention to non-core subjects (general education unit). The advantages of literate tutorials made by this method are undeniable in the current situation, but it should not be forgotten that the creation of such manuals involves preliminary processing of information, that is, assumes that someone still works with the source. This is where the gap comes in - the clips are focused on the consumer of ready-made images and conclusions to which the author of the guide (author-mediator) draws the reader. There is a risk of distortion of information, falsification of facts, accentuation of some aspects and silence of others. Only the primary source makes it possible to form your own unbiased opinion about any subject and to consider it precisely from the side that subjectively seems to someone most interesting, otherwise, the reader risks being misled. One cannot ignore the fact that humanity has been steadily moving towards a new style of thinking over the centuries, which is likely to be just another stage in the development of mankind, a vector that one generation cannot change. The question of evaluating a new cognitive style remains open.

Modern education is incapable of forcing a person to create stable logical chains and to systematically qualify the data obtained. Instead, the number of people with cognitive thinking in the walls of higher education will increase every year. And it can lead to disaster if you do not look for ways to adapt the higher education system to the present.

In view of the above, we see the need to create alternative educational programs, to change the structure of information provision, to translate textbooks into a multilevel structure, where the first level would allow for a maximum of twenty minutes to get acquainted with the general idea in a couple of dozen «paragraph clips «, And each subsequent went deeper questions, systematizing the previously obtained knowledge. Books in this coordinate system will go to the last level and will also have to change qualitatively.

Addressing the issue of clinical thinking that senior teachers in medical colleges face requires detailed study. The inability of the student, even the «theoretical» honors student, to use, systematize the acquired knowledge every year causes more and more dissatisfaction and leads to a decrease in vocational training.

Another threat is endless testing. The situational task is a form traditionally used in the study of clinical disciplines. However, in most cases 
the tasks are designed in such a way as to limit creative activity. The tasks contain ready-made answers to the questions that arise in the objective examination of the patient (enlarged liver, determined ascites, etc.). As a rule, a set of clinical research methods is added, reflecting an idea of a given clinical condition from the position of the author of the situation of the compiler of the task, but not the student. The use of tests in education reduces the critical, analytical capacity of students, again forcing only the fragments of a particular phenomenon to be captured, without explaining its causes, patterns, without constructing logical circuits. Solving certain test tasks, we, of course, evaluate the level of knowledge (learning) of the student, but deprive him of the opportunity to think, and even to speak professionally. Therefore, supersaturation of various kinds of tests also adversely affects the formation of clinical thinking, which is the basis in medical universities.

It is advisable to make the class «outwardly attractive» - it can be a game form, giving examples from own experience, interesting tasks with practical results, etc. There should be a constant dialogue between the teacher and the students, they should be given the opportunity to independently (or consolidate) the necessary practical skills, to acquire modern diagnostic methods of research, as well as to prepare theoretical material in the form of a presentation on a highly specialized topic and to report to all students with further discussion. In the course of ethics-professional training, focused on personality, there must be a subject-subject relations. Efforts and active actions of all participants of the educational process are directed to selfdevelopment, self-realization of their own positive «I» - concept. The educational process is intended to ensure the integrity of the formation of the professional and civic status of young assistants while maintaining the individuality of each student's personality. It is this requirement that is one of the important aspects of becoming a socially-mature personality of a professional in higher education. A very important role is played by the creation of emotional and psychological comfort of the student in the process of submission of educational material. With the help of note taking you can design a model of the problem, both structural and conceptual. Summaries make it easier to remember the text. It will improve your ability to understand special terms. Writing in a concise way allows you to gather enough information needed to write a much more complex work, which will appear in the form of reports, abstracts, diploma and course papers, 
dissertations, articles, books. The process also includes «hand memory», that is, written. It is very important to give students an opportunity to understand why they have all this knowledge. This point should be explained as simply as possible (starting from the current political and economic environment).

It is proved that the system of increasing motivation to study is based on the systematic work of the teachers of the department to improve the level of professional and pedagogical skills. It is recommended to involve students in scientific work with the subsequent presentation of their results, as well as work and study outside the classroom under the supervision of the teacher with an objective assessment of the acquired knowledge and skills. It is the close collaboration between the teacher and the student in the classroom and extracurricular work, and the highly professional level of teaching using innovative teaching methods that make up the reserve to increase students' motivation for learning. The use of student activation methods is the most important principle of postgraduate study. Solution of diagnostic and medical problems, problem situations, participation in training games provides a sufficiently high professional training. In the learning process, students are forced to actively find, study and use educational and scientific information, which is more useful than traditional ways of teaching practical activity. The modern educational process actualizes the leadership qualities of young people, instilling in them a taste for the new and progressive, encouraging them to study the latest medical technologies.

\section{CONCLUSIONS}

Modern medical education requires the formation of a qualitatively new approach to the educational process, which will be based on the formation and development of clinical thinking, taking into account the psychological characteristics of modern youth. The «clip-on» way of working with information adds dynamism to cognitive learning activities, which allows, in the context of the growing volume of educational material, to manage, sometimes even formally, the necessary tasks. Clip behavior allows you to see the multifaceted, multivariate, ambiguous approaches to analyzing or solving specific issues and tasks (this thinking helps the audience to better understand and understand the wide variety of relationships between phenomena and events). However, it cannot neglect the negative consequences of this process. Constructing the educational process in accordance with the needs of the curriculum should take into account their 
own tasks against the background of progressive changes in the thinking of young people. The results may not be conclusive, but they do indicate a positive trend toward an evolutionary increase in the ability to «clip-think» in the following age groups of students. The results obtained coincide with the fact that the professional training of students who only master basic disciplines and interns who have completed the basic training course gives similar, but at the same time different data of the same survey. It is not possible to definitively determine in which group the level of "clip thinking" prevails. However, this fact testifies to the irreversibility of changes in «new thinking» that should be taken into account in teaching. Modern education is incapable of forcing a person to create stable logical chains and to systematically qualify the data obtained. Instead, the number of people with cognitive thinking in the walls of higher education will increase every year. And it requires looking for ways to adapt the higher education system to the present.

\section{SUMMARY}

The work is devoted development research «clip thinking» at medical students at various grade levels. The comparative analysis by results of poll of students and doctors-interns is carried out. It is noticed that «the clip thinking» influences reception of the information in the course of training. Positive dynamics of evolutionary changes in "clip thinking" among middle and senior students is noted. This circumstance should be considered at drawing up of curriculums and preparation for employment.

\section{REFERENCES}

1. Barannyk S.I., Yekhalov V.V., Romanyuta I.A., Lyashchenko P.V. (2018). Intehratsiya «klipovoho myslennya» v suchasnu vyshchu medychnu osvitu. Pivdennoukrayins'kyy medychnyy naukovy zhurnal. №19(19) february. pp. 8-12.

2. Barannyk S.I., Yekhalov V.V., Mizyakina K.V., Barannik K.S. (2019). Evolyutsiyni aspekty «Klipovoho myslennya» u studentiv-medykiv ta yikh intehratsiya u vyshchu medychnu osvitu. "Sotsial'no-humanitarni doslidzhennya ta innovatsiyna osvitnya diyal'nist'» Materialy Mizhnarodnoyi naukovoyi konferentsiyi. 24-25 travnya 2019 r., m. Dnipro / Nauk. red. O.YU. Vysots'kyy. Dnipro: SPD «Okhotnik». 528 P. pp 435-438. 
3. Hych H. M. (2016). «Klipove» myslennya molodi: druh chy voroh navchannya? Naukovi pratsi. Pedahohika, vipusk. 257. T. 269. p3.38-42.

4. Yekhalov V.V., Sedinkin V.A., Barannyk S.I. (2017). «Klipove myslennya» ta suchasna vyshcha medychna osvita. Aktual'ni pytannya osvity i nauky: zbirnyk naukovykh statey, materialy $\mathrm{V}$ mizhnarodnoyi naukovo-praktychnoyi konferentsiyi 10-11 lystopada 2017 r. / Natsional'na akademiya Natsional'noyi hvardiyi Ukrayiny. Kharkiv: KHOHOKZ. 384 p. pp. 172-178.

5. Yekhalov V.V., Samoylenko A.V., Romanyuta I.A., Barannyk S.I. (2018). Klinichne ta «klipove» myslennya u likariv-interniv. Ukrayins'kyy zhurnal medytsyny, biolohiyi ta sportu. Tom 3, №1(10). pp. 241-244.

6. Kligunenko Ye.N., Yekhalov V.V., Kushch Ye.A., Kravets O.V., Gayduk O.I., Barannik S.I., Khobotova N.V.(2019)/ Klipovoye myshleniye v anesteziologii: katastrofa ili zakonomernost'? Meditsina nevídkladnikh staní. №3(98). pp. 111-123.

7. Litvinova M.B. (2017). Dosvid diahnostuvannya klipovoho myslennya. Pedahohichni nauky Vypusk LXXVI, Tom 3. pp. 140-145.

8. Nesterova L.YU., Napalkov S.V. (2016). Razvitiye klipovogo myshleniya $\mathrm{u}$ studentov $\mathrm{v}$ sisteme vysshego obrazovaniya posredstvom opornykh graf-skhem. Vestnik Nizhegorodskogo universiteta im. N.I. Lobachevskogo. Seriya: Sotsial'nyye nauki. № 4 (44). pp. 207-215.

9. Semenovskikh T. V. Fenomen (2014) «klipovogo myshleniya» v obrazovatel'noy vuzovskoy srede. Internet-zhurnal «Naukovedeniye», vip. 5(24). pp. 1-10.

Information about the author: Barannik K. S., orcid.org/0000-0002-1009-4990 Candidate of Medical Sciences, Assistant at the Department of Urology Dnepropetrovsk Medical Academy of the Ministry of Health of Ukraine 9, Vernadsky str., Dnipro, 49044, Ukraine 
Publishing house "Liha-Pres"

9 Kastelivka str., Lviv, 79012, Ukraine

44 Lubicka str., Toruń, 87-100, Poland

Printed by the publishing house "Liha-Pres"

Passed for printing: November 25, 2019.

A run of 150 copies. 